\title{
VERIFICATION OF THE DEFENSE WASTE PROCESSING FACILITY'S (DWPF) PROCESS DIGESTION METHOD FOR THE SLUDGE BATCH 6 QUALIFICATION SAMPLE
}

D. R. Click

T. B. Edwards

M. A. Jones

June 9, 2010

Savannah River National Laboratory Savannah River Nuclear Solutions, LLC Aiken, SC 29808

Prepared for the U.S. Department of Energy under contract number DE-AC09-08SR22470.

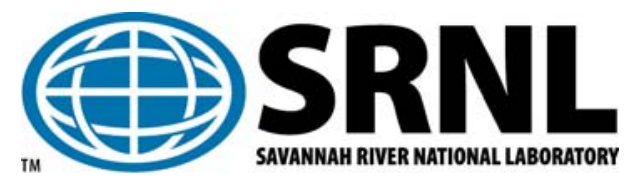


DISCLAIMER

This work was prepared under an agreement with and funded by the U.S. Government. Neither the U.S. Government or its employees, nor any of its contractors, subcontractors or their employees, makes any express or implied:

1. warranty or assumes any legal liability for the accuracy, completeness, or for the use or results of such use of any information, product, or process disclosed;

2. representation that such use or results of such use would not infringe privately owned rights; or

3. endorsement or recommendation of any specifically identified commercial product, process, or service. Any views and opinions of authors expressed in this work do not necessarily state or reflect those of the United States Government, or its contractors, or subcontractors.

Printed in the United States of America

Prepared For

U.S. Department of Energy 
Key Words: method development, analytical process

Retention:

Permanent

\section{VERIFICATION OF THE DEFENSE WASTE PROCESSING FACILITY'S (DWPF) PROCESS DIGESTION METHOD FOR THE SLUDGE BATCH 6 QUALIFICATION SAMPLE}

D. R. Click

T. B. Edwards

M. A. Jones

June 9, 2010

Savannah River National Laboratory

Savannah River Nuclear Solutions, LLC Aiken, SC 29808

Prepared for the U.S. Department of Energy under contract number DE-AC09-08SR22470.

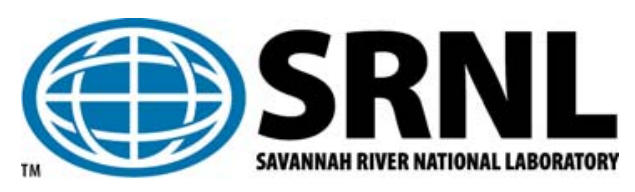


This page intentionally left blank 


\section{REVIEWS AND APPROVALS}

D.R. Click, Author, Analytical Development, SRNL

Date

T.B. Edwards, Co-Author, Statistical Consulting, SRNL

Date

D.K. Peeler, Technical Reviewer, Process Technology Programs, SRNL

Date

J.M. Pareizs, Technical Reviewer, Process Technology Programs, SRNL

Date

C.J. Coleman, Technical Reviewer, Analytical Development, SRNL

Date

C.C. Herman, Manager, DWPF Programs, SRNL

Date

C.M. Gregory, Manager, Spectroscopy and Separations, Analytical Development, SRNL Date

J.E. Occhipinti, SRR Engineering

Date 
This page intentionally left blank 


\section{TABLE OF CONTENTS}

LIST OF FIGURES AND TABLES

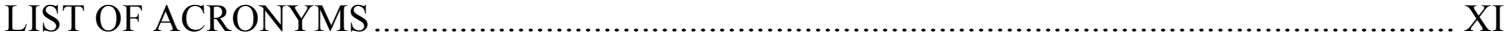

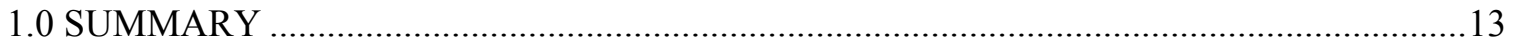

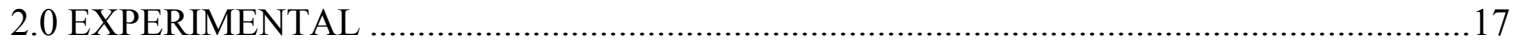

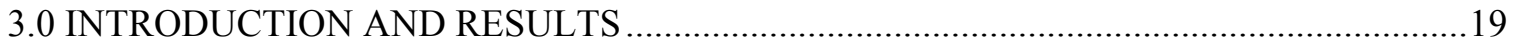

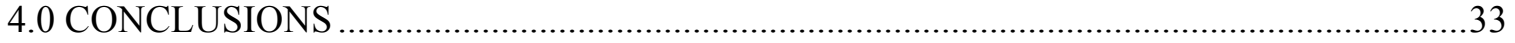

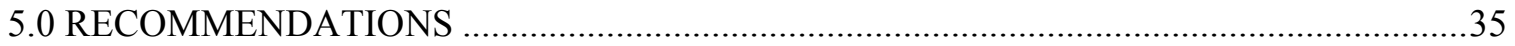

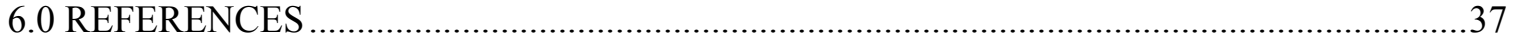

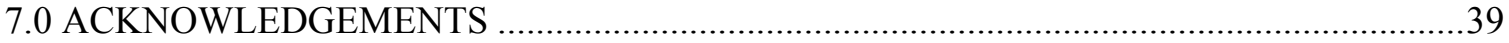

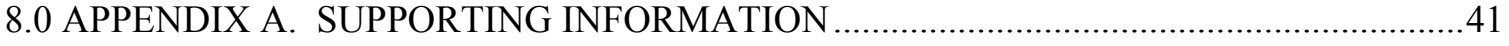


This page intentionally left blank 


\section{LIST OF FIGURES AND TABLES}

Table 3-1 Elemental concentrations of Th and U from ICP-AES and ICP-MS analysis of Aqua Regia, DWPF Cold Chem method and Sodium Peroxide/Hydroxide Fusion digestions. Values are presented on a weight percent $(\mathrm{Wt} \%)$ total solids basis and are reported to the first digit of the calculated standard deviation....20

Table 3-2 Elemental concentrations of SB6 SRAT Receipt radioactive sludge slurry obtained from ICP-AES analysis of Aqua Regia, DWPF Cold Chem method and Sodium Peroxide/Hydroxide Fusion digestions. Values are presented on a weight percent $(\mathrm{Wt} \%)$ of total dried solids basis.

Table 3-3 Statistical comparison of Aqua Regia, DWPF Cold Chem method and Sodium Peroxide/Hydroxide Fusion digestions of SB6 SRAT Receipt sludge. Digestions not having the same letter are statistically different at the $5 \%$ significance level.

Table 3-4 Elemental concentrations of SB6 SRAT Product radioactive sludge slurry obtained from ICP-AES analysis of Aqua Regia, DWPF Cold Chem method and Sodium Peroxide/Hydroxide Fusion digestions. Values are presented on a weight percent $(\mathrm{Wt} \%)$ total dried solids basis.

Table 3-5 Statistical comparison of Aqua Regia, DWPF Cold Chem method and Sodium Peroxide/Hydroxide Fusion digestions of SB6 SRAT Product sludge. Digestions not having the same letter are statistically

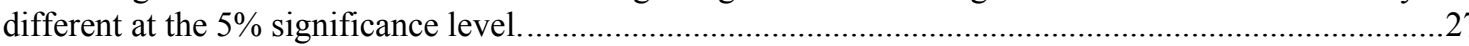

Table 3-6. Elemental concentrations of ARG standard from ICP-AES analysis of Aqua Regia, DWPF Cold Chem method and Sodium Peroxide/Hydroxide Fusion digestions performed concurrently with SB6 SRAT Receipt Sample. Values are presented on a weight percent (Wt\%) total solids basis. Digestions not having the same letter are statistically different at the 5\% significance level.

Table 3-7. Continuation of elemental concentrations of ARG standard from ICP-AES analysis of Aqua Regia, DWPF Cold Chem method and Sodium Peroxide/Hydroxide Fusion digestions performed concurrently with SB6 SRAT Receipt Sample. Values are presented on a weight percent $(\mathrm{Wt} \%)$ total solids basis......30

Table 3-8. Elemental concentrations of ARG standard from ICP-AES analysis of Aqua Regia, DWPF Cold Chem method and Sodium Peroxide/Hydroxide Fusion digestions performed concurrently with SB6 SRAT Product sample. Values are presented on a weight percent (Wt\%) total solids basis.

Table 3-9. Continuation of elemental concentrations of ARG standard from ICP-AES analysis of Aqua Regia, DWPF Cold Chem method and Sodium Peroxide/Hydroxide Fusion digestions performed concurrently with SB6 SRAT Product sample. Values are presented on a weight percent $(\mathrm{Wt} \%)$ total solids basis. ......32

Table 3-10. CV Hg AA results of digested SB6 SRAT Receipt using the DWPF method and an Aqua Regia digestion for comparison. Values are presented on a weight percent $(\mathrm{Wt} \%)$ total dried solids basis and $\% \mathrm{RSD}$ is given in parentheses. 
This page intentionally left blank 


\section{LIST OF ACRONYMS}

$\begin{array}{ll}\text { AD } & \text { Analytical Development } \\ \text { AR } & \text { Aqua Regia } \\ \text { ARP } & \text { Actinide Removal Process } \\ \text { ARG } & \text { Analytical Reference Glass } \\ \text { CC } & \text { Cold Chem } \\ \text { DI } & \text { De-Ionized } \\ \text { DOE } & \text { Department of Energy } \\ \text { DWPF } & \text { Defense Waste Processing Facility } \\ \text { HM } & \text { H-Modified (pertaining to PUREX process) } \\ \text { ICP-AES } & \text { Inductively Coupled Plasma - Atomic Emission Spectroscopy } \\ \text { IEC } & \text { Inter-element Correction } \\ \text { LTAD } & \text { Low Temperature Aluminum Dissolution } \\ \text { LWO } & \text { Liquid Waste Operations } \\ \text { MCU } & \text { Modular Caustic Side Solvent Extraction } \\ \text { MST } & \text { Monosodium Titanate } \\ \text { PF } & \text { Sodium Peroxide/Hydroxide Fusion } \\ \text { SB } & \text { Sludge Batch } \\ \text { SE } & \text { Stream Effluent } \\ \text { SME } & \text { Slurry Mix Evaporator } \\ \text { SRAT } & \text { Sludge Receipt and Adjustment Tank } \\ \text { SRNL } & \text { Savannah River National Laboratory } \\ \text { WAPS } & \text { Waste Acceptance Product Specification } \\ \text { C-XRD } & \text { Contained - X-Ray Diffraction }\end{array}$


This page intentionally left blank 
SRNL-STI-2010-00259, REVISION 0

\subsection{SUMMARY}

For each sludge batch that is processed in the Defense Waste Processing Facility (DWPF), the Savannah River National Laboratory (SRNL) confirms applicability of the digestion method to be used by the DWPF lab for elemental analysis of Sludge Receipt and Adjustment Tank (SRAT) receipt samples and SRAT product process control samples. ${ }^{1}$ DWPF SRAT samples are typically dissolved using a room temperature $\mathrm{HF}-\mathrm{HNO}_{3}$ acid dissolution (i.e., DWPF Cold Chem (CC) Method, see DWPF Procedure SW4-15.201) and then analyzed by inductively coupled plasma - atomic emission spectroscopy (ICPAES). In addition to the CC method confirmation, the DWPF lab's mercury (Hg) digestion method was also evaluated for applicability to SB6 (see DWPF procedure "Mercury System Operating Manual", Manual: SW4-15.204. Section 6.1, Revision 5, Effective date: 12-04-03.

This report contains the results and comparison of data generated from performing the Aqua Regia (AR), Sodium Peroxide/Hydroxide Fusion (PF) and DWPF Cold Chem (CC) method digestion of Sludge Batch 6 (SB6) SRAT Receipt and SB6 SRAT Product samples. For validation of the DWPF lab's Hg method, only SRAT receipt material was used and compared to AR digestion results. The SB6 SRAT Receipt and SB6 SRAT Product samples were prepared in the SRNL Shielded Cells, and the SRAT Receipt material is representative of the sludge that constitutes the SB6 Batch or qualification composition. This is the sludge in Tank 51 that is to be transferred into Tank 40, which will contain the heel of Sludge Batch 5 (SB5), to form the SB6 Blend composition. In addition to the 16 elements currently measured by the DWPF, this report includes $\mathrm{Hg}$ and thorium (Th) data (Th comprising $\sim 2.5-3 \mathrm{Wt} \%$ of the total solids in SRAT Receipt and SRAT Product, respectively) and provides specific details of ICP-AES analysis of Th. Thorium was found to interfere with the U $367.007 \mathrm{~nm}$ emission line, and an inter-element correction (IEC) had to be applied to U data, which is also discussed. The results for any one particular element should not be used in any way to identify the form or speciation of a particular element without support from XRD analysis or used to estimate ratios of compounds in the sludge.

The results from the SRAT Receipt digestions include the following:

- $\quad$ The SRAT Receipt AR and CC digestion solutions contained white visible solids. The PF digestions solutions did not contain visible solids. The undissolved solids from the AR digestions were identified as boehmite from C-XRD analysis. The undissolved solids from the $\mathrm{CC}$ digestions were identified as calcium thorium fluoride $\left(\mathrm{Ca}_{0.5} \mathrm{Th}_{0.5} \mathrm{~F}_{3}\right)$.

- No statistical difference of the means is observed in the Al concentration between the three digestions, indicating the undissolved amount of boehmite in the AR digestions is small or of small enough particle size to be still be analyzed by the ICP-ES.

- A statistical difference of means at the 5\% significance level is noted for $\mathrm{Fe}, \mathrm{Mn}, \mathrm{Na}, \mathrm{Ni}$, Th, and $\mathrm{U}$ (for the elements greater than $1.0 \mathrm{Wt} \%$ of total solids). Fe, Mn, Na, Ni, and Th mean concentrations are lower in the $\mathrm{CC}$ digestions compared to the AR and PF digestions.

- The DWPF method used for digesting Hg appears to be adequate for the SB6 sludge slurry.

The results from the SRAT Product digestions include the following:

- As with the SRAT Receipt sample, the SRAT Product AR and CC digestion solutions contained visible white solids. The PF digestion solutions did not contain visible solids. The undissolved solids in the AR digestions were assumed to be boehmite based upon C-XRD analysis of the undissolved solids in the SRAT Receipt samples. The undissolved in the CC digestions have not been analyzed to date.

- A statistical difference in the means is observed in the Al concentration comparing the PF digestions to both the AR and $\mathrm{CC}$ digestions. The mean $\mathrm{Al}$ concentration is higher in the PF 
digestions. The average $\mathrm{Al}$ concentration in the $\mathrm{CC}$ digestions is $\sim 6.6 \%$ lower than the $\mathrm{PF}$ digestions, and the average $\mathrm{Al}$ concentration from the $\mathrm{AR}$ digestions is $\sim 7.7 \%$ lower than the $\mathrm{PF}$ digestions indicating an aluminum species that is sparingly soluble in acid digestions.

- A statistical difference of means at the $5 \%$ significance level is noted for $\mathrm{Fe}, \mathrm{Mn}, \mathrm{Na}, \mathrm{Ni}$, and Th (for the elements greater than $1.0 \mathrm{Wt} \%$ of total solids). As with the SRAT Receipt sample, $\mathrm{Fe}, \mathrm{Mn}, \mathrm{Na}$, and $\mathrm{Ni}$ concentrations are lower in the $\mathrm{CC}$ digestions compared to the $\mathrm{AR}$ and $\mathrm{PF}$ digestions. The mean Th concentration is statistically different in the $\mathrm{CC}$ digestions compared to the AR digestions, but there is no statistically significant difference compared to the PF digestions.

The results from a statistical and relative comparison of the data suggest that the DWPF CC method may not be completely solubilizing the following:

- $\mathrm{Fe}$, which is $\sim 11-16 \%$ lower in the $\mathrm{CC}$ digestions relative to the $\mathrm{PF}$ and AR digestions.

- $\mathrm{Mn}$, which is $\sim 5-7 \%$ lower in the $\mathrm{CC}$ digestions relative to the PF and AR digestions.

- $\mathrm{Ni}$, which is $\sim 10-12 \%$ lower in the $\mathrm{CC}$ digestions relative to the PF and AR digestions.

- Th, which is $\sim 4-25 \%$ lower in the CC digestions relative to the PF and AR digestions.

- The low results observed for Fe, Mn, and Ni in the CC digestions of the SB6 SRAT Receipt and SRAT Product are not mirrored in the ARG results indicating a potential problem with digestion of the sludge matrix.

In addition, the mean $\mathrm{Na}$ concentration is $\sim 4 \%$ lower in the $\mathrm{CC}$ digestions versus the aqua regia digestions.

The results from Th analysis of SB6 SRAT Receipt and SRAT Product include the following:

- Calcium thorium fluoride $\left(\mathrm{Ca}_{0.5} \mathrm{Th}_{0.5} \mathrm{~F}_{3}\right)$ is a constituent of the precipitated solids in the SRAT Receipt CC digestions (from C-XRD analysis). Undisssolved solids in the SRAT Product have not been analyzed to date, but the C-XRD analysis is expected to yield a similar result.

- ICP-AES measurements of Th in the CC digestions at $1.3 \mathrm{~kW}$ using the Th $374.118 \mathrm{~nm}$ and Th $401.913 \mathrm{~nm}$ emission lines in axial mode gave comparable results to ICP-MS measurements performed at $1.35 \mathrm{~kW}$.

- ICP-AES measurements of Th in the CC digestions at $1.1 \mathrm{~kW}$ in both radial and axial modes are $\sim 40 \%$ lower than ICP-MS measurements obtained at $1.35 \mathrm{~kW}$.

- ICP-AES Th results from axial and radial modes at $1.1 \mathrm{~kW}$ (using the $318.019 \mathrm{~nm}$ emission line) of AR and PF digestions were comparable to ICP-MS measurements at $1.35 \mathrm{~kW}$.

- Th interferes with the U $367.007 \mathrm{~nm}$ emission line, and an inter-element correction (IEC) was applied to all $\mathrm{U}$ data (IEC factor of $\sim 0.2$ in radial mode and $\sim 0.15$ in axial mode).

- No significant interference from $U$ on Th emission lines utilized in this study was noted.

Based on the comparison of digestion methods tested at SRNL for SB6, we present the following short and long-term recommendations:

- A dissolution study should be performed on the SB6 WAPS sample by SRNL, which consists of the final composition of the sludge (the SB6 Blend), to determine if the $\mathrm{Fe}, \mathrm{Mn}, \mathrm{Ni}$, and $\mathrm{Th}$ concentrations are consistently lower in the $\mathrm{CC}$ digestions versus the $\mathrm{AR}$ and $\mathrm{PF}$ methods for SB6.

- Given the problems seen with measuring Al by the CC method for SB5 and that a SB5 heel remains in Tank 40, the DWPF lab should monitor the Al concentration in the first 10 SRAT 
Receipt batches of SB6 using both CC and PF methods to evaluate the adequacy of Al recovery by the CC method for SB6.

- Given the statistical difference and high relative difference in the means for $\mathrm{Fe}, \mathrm{Mn}, \mathrm{Ni}$, and $\mathrm{Th}$, the DWPF lab should also monitor these elements in the first 10 SRAT Receipt batches of SB6 using both the $\mathrm{CC}$ and $\mathrm{PF}$ methods to evaluate the adequacy of recovery by the $\mathrm{CC}$ method for SB6.

- The DWPF lab should establish an ICP-AES method to measure Th, determine which U emission lines are appropriate, and determine if an IEC needs to be applied to $U$ data due to the presence of Th, using this report only as a guide.

- The DWPF CC method was originally developed to be used for SME analyses. Given continuous visual observations of solids in the CC digestions both at SRNL and DWPF, potential issues with accurate $\mathrm{Al}$ measurements when processing HM waste, and the results of this report, the DWPF lab should consider a different digestion scheme that relieves some of these issues. Other digestion methods have been developed at SRNL targeting the DWPF lab's process sample analysis. $^{2}$

- The impact of the results of this study need to be assessed against the blending spreadsheet used in DWPF for predicting the glass processing properties to determine the potential impact on SME acceptability. Specifically, the DWPF should compare SRAT blending projections to the SME product results. If the difference in elemental concentrations is significant, another type of digestion (i.e. sodium peroxide/hydroxide fusion) should be used to determine the concentration of the element in question. Additional emphasis should be placed on monitoring Al, Fe, Ni and Th concentrations in SB6, and in particular the Mn concentration which could have a potential impact on the calculated acid addition amount. 
This page intentionally left blank 
SRNL-STI-2010-00259, REVISION 0

\subsection{EXPERIMENTAL}

The radioactive sludge slurry used in this study for verification of the DWPF CC method is from the three liter qualification sample of Tank 51 sludge slurry taken in October of 2009. The sample was delivered to SRNL, characterized and then modified by a series of wash/decant cycles to match the LWO planned preparation strategy. The sludge used in this testing corresponded to Decant I, identified by Bannochie et al. in SRNL-L3100-2010-00027, which is the SB6 qualification sample or the SRAT Receipt sample and the subsequent SRAT Product sample.

The sludge samples were dissolved in quadruplicate in the SRNL Shielded Cells facility in a manner similar to the DWPF CC method (see DWPF Procedure SW4-15.201), and by PF and AR digestion. For detailed steps of the PF digestion, see ADS procedure $2502 .{ }^{3}$ The PF digestion was modified by adding 3 drops $30 \%$ hydrogen peroxide $\left(\mathrm{H}_{2} \mathrm{O}_{2}\right)$ to the solutions before the final dilution was complete. For detailed steps of the AR digestion, see ADS procedure $2226 .{ }^{4}$ Three replicate dissolutions of the analytical reference glass (ARG) standard were performed concurrently with each set of digestions as means to indicate problems with performing the digestion protocol and to test the validity of each digestion method for major elements. The ARG results are then evaluated comparing the measured results against a two sigma variation of the standard values. For the SRAT Receipt material, Al (slightly low), Mn (slightly low) and $\mathrm{Si}$ (as expected) were flagged as outside of the 2 sigma limits for the AR digestions, Si was flagged as outside the 2 sigma limits (slightly low) for the PF digestions as well as the CC digestions (expected for the CC digestions). For the SRAT product material, Si (as expected) was flagged as outside of the 2 sigma limits for the AR digestions as well as the $\mathrm{CC}$ digestions (as expected). No elements were flagged for the three digestions. One feldspar sample and one boehmite sample was also digested along with the PF and CC digestions of the SRAT material. The recovery of Al from PF digestion of the feldspar and beohmite standards was within $5.5 \%$ of the standard value. The recovery of Al from CC digestion of the feldspar standard was within $5 \%$ of the standard value indicating the CC digestion is valid for digesting sodium aluminum silicates. The recovery of $\mathrm{Al}$ from $\mathrm{CC}$ digestion of the beohmite standard was low by $84 \%$. Additional quality control measures included ICP-AES analyses of a multi-element standard as a check for ICP-AES accuracy independent of digestions.

The CC method digestion involved adding $25 \mathrm{~mL}$ of concentrated HF to radioactive sludge slurry $(\sim 3.5 \mathrm{~g}$ for the SRAT Receipt at $15.1 \mathrm{Wt} \%$ total solids and $\sim 3.5 \mathrm{~g}$ for the SRAT Product at $25.93 \mathrm{Wt} \%$ total solids) and stirring for $1 \mathrm{hr}$. Then, $25 \mathrm{~mL}$ of concentrated $\mathrm{HNO}_{3}$ was added and the mixture was stirred for an additional 30 minutes prior to diluting with de-ionized (DI) water to $250 \mathrm{~mL}$ in a pre-weighed volumetric flask. The density of the solution was obtained from the weight of the $250 \mathrm{~mL}$ of solution. Approximately $15 \mathrm{~g}$ of solution was taken from the $250 \mathrm{~mL}$ volumetric flask and added to a $100 \mathrm{~mL}$ volumetric flask with a known weight, weighed again and then diluted with DI water. Visible solids remained in each $250 \mathrm{~mL}$ radioactive sample bottle (the first dilution bottle). The visible solids from one sample of each type (SRAT Receipt and SRAT Product) were recovered by filtration for C-XRD analysis.

ICP-AES measurements were performed using a Leeman Prodigy Simultaneous instrument. In addition to the 16 elements currently analyzed by the DWPF, Th is also included in this report. The best Th measurements were performed using the Th $374.118 \mathrm{~nm}$ and $\mathrm{Th} 401.913 \mathrm{~nm}$ emission lines in axial mode at $1.3 \mathrm{~kW}$ for the Cold Chem digestions, which gave comparable results to ICP-MS measurements performed at $1.35 \mathrm{~kW}$. The $\mathrm{U}$ data in this report is from axial or radial analysis performed at $1.1 \mathrm{~kW}$. Th was found to interfere with the $\mathrm{U} 367.007 \mathrm{~nm}$ emission line and an IEC was applied to all $\mathrm{U}$ data $(\sim 0.2 \mathrm{in}$ radial mode and $\sim 0.15$ in axial mode). 
Hg Analysis

The DWPF procedure "Mercury System Operating Manual", Manual: SW4-15.204. Section 6.1, Revision 5, Effective date: 12-04-03 was followed to perform digestions on SRAT Receipt material. To serve as a quality control check on mercury analyses, a soil standard containing a known concentration of mercury was dissolved and analyzed concurrently with the samples. 


\subsection{INTRODUCTION AND RESULTS}

The DWPF is currently processing and immobilizing radioactive sludge slurry into a durable borosilicate glass. The DWPF has already processed five sludge batches (Sludge Batch 1A, Sludge Batch 1B, Sludge Batch 2, Sludge Batch 3, Sludge Batch 4) and is currently processing a sixth (Sludge Batch 5). A sludge batch is defined as a single tank of sludge or a combination of sludges from different tanks that has been or will be qualified before being transferred to DWPF. Thus, following the sludge batch preparation plan of the Liquid Waste Organization (LWO), the qualified sludge in Tank 51 is to be blended with the heel of the previous sludge batch in Tank 40. The sludge being qualified at the SRNL (referred to as a "batch" composition in sludge batch planning) is to be combined with the heel of the previous sludge batch in DWPF to yield the "blend" composition. The next batch of radioactive sludge slurry to be processed by the DWPF is SB6. The subject of this report is the SB6 material from Tank 51 that is being qualified at SRNL, which is the SB6 Batch sludge slurry consisting of Tank 12 material that has been transferred to Tank 51 to undergo Low Temperature Aluminum Dissolution (LTAD) to reduce the Al content of the insoluble solids ${ }^{5}$, Tank 4 sludge, and H-Canyon Pu solutions. The Tank 51 material will be blended after qualification with a SB5 heel. As with SB4 and SB5, a stream of sludge/monosodium titanate (MST) from the Actinide Removal Process (ARP) and a Strip Effluent (SE) stream from the Modular Caustic Side Solvent Extraction (MCU) process will also be fed to DWPF during SB6 processing.

The radioactive sludge slurry used in this study for verification of the DWPF CC method is from a three liter qualification sample of Tank 51 sludge slurry taken in October of 2009. The sample was delivered to SRNL, characterized and then modified by a series of wash/decant cycles to match the LWO planned preparation strategy. The sludge used in this testing corresponded to Decant I, identified by Bannochie et al. in SRNL-L3100-2010-00027 Rev. 1, which is the SB6 qualification SRAT Receipt sample and subsequently, the SRAT Product sample.

The SRAT Receipt and SRAT Product analytical sub-samples were digested in quadruplicate using the AR, PF and the DWPF CC methods. Three ARG samples were digested concurrently with each set of digestions and two multi-element ICP-AES standards were submitted along with each sample batch for analysis containing known concentrations of $\mathrm{Al}, \mathrm{B}, \mathrm{Fe}, \mathrm{Li}, \mathrm{Na}$, and $\mathrm{Si}$.

\section{Results}

SB6 feed was found to contain Th after the initial analysis of the SRAT receipt and SRAT Product samples were complete. Th analysis by ICP-MS is straightforward since Th has $100 \%$ of its relative natural abundance at mass 232. However, an ICP-AES method had to be developed at SRNL since Th is not part of the routine suite reported to customers. During development of the Th method at SRNL, it was found that Th interfered with $\mathrm{U}$ analysis by ICP-AES. U is measured using the $\mathrm{U} 367.007 \mathrm{~nm}$ and an IEC of $\sim 0.2$ had to be applied to $U$ data measured in radial mode, and an IEC of $\sim 0.15$ had to be applied to $\mathrm{U}$ data measured in axial mode. Table 3-1 presents the results from analysis of Th and U by ICP-MS and ICP-AES both before and after correction for Th interference on the $\mathrm{U}$ emission line. 
Table 3-1 Elemental concentrations of Th and U from ICP-AES and ICP-MS analysis of Aqua Regia, DWPF Cold Chem method and Sodium Peroxide/Hydroxide Fusion digestions. Values are presented on a weight percent $(\mathrm{Wt} \%)$ total solids basis and are reported to the first digit of the calculated standard deviation.

\begin{tabular}{|c|c|c|c|}
\hline \multicolumn{4}{|c|}{ SRAT Receipt } \\
\hline \multicolumn{4}{|c|}{ Digestion Method: PF } \\
\hline & $\mathrm{Th}(\mathrm{Wt} \%)$ & $\mathrm{U}(\mathrm{Wt} \%)$ & $\mathrm{U}(\mathrm{Wt} \%)$ after IEC for Th Interference \\
\hline ICP-MS & $2.83 \mathrm{E}+00$ & $2.21 \mathrm{E}+00^{*}$ & $\mathrm{~N} / \mathrm{A}$ \\
\hline ICP-AES & $\begin{array}{l}2.85 \mathrm{E}+00 \text { (radial mode) } \\
2.79 \mathrm{E}+00 \text { (axial mode) }\end{array}$ & $\begin{array}{c}2.50 \mathrm{E}+00 \\
\text { (prior to IEC) }\end{array}$ & $\begin{array}{l}2.18 \mathrm{E}+00 \text { (radial mode) } \\
2.31 \mathrm{E}+00 \text { (axial mode) }\end{array}$ \\
\hline \multicolumn{4}{|c|}{ Digestion Method: AR } \\
\hline & $\mathrm{Th}(\mathrm{Wt} \%)$ & $\mathrm{U}(\mathrm{Wt} \%)$ & $\mathrm{U}(\mathrm{Wt} \%)$ after IEC for Th Interference \\
\hline ICP-MS & $2.98 \mathrm{E}+00$ & $2.33 \mathrm{E}+00^{*}$ & $\mathrm{~N} / \mathrm{A}$ \\
\hline ICP-AES & $\begin{array}{l}3.06 \mathrm{E}+00 \text { (radial mode) } \\
3.07 \mathrm{E}+00 \text { (axial mode) }\end{array}$ & $\begin{array}{c}2.42 \mathrm{E}+00 \\
\text { (prior to IEC) }\end{array}$ & $\begin{array}{c}2.41 \mathrm{E}+00 \text { (radial mode) } \\
2.48 \mathrm{E}+00(\text { axial mode })\end{array}$ \\
\hline \multicolumn{4}{|c|}{ Digestion Method: CC } \\
\hline & $\mathrm{Th}(\mathrm{Wt} \%)$ & $\mathrm{U}(\mathrm{Wt} \%)$ & $\mathrm{U}(\mathrm{Wt} \%)$ after IEC for Th Interference \\
\hline ICP-MS & $2.49 \mathrm{E}+00$ & $2.16 \mathrm{E}+00^{*}$ & $\mathrm{~N} / \mathrm{A}$ \\
\hline ICP-AES & $\begin{array}{c}\text { 4.E-01 (radial mode) } \\
1.3 \mathrm{E}+00 \text { (axial mode) } \\
2.6 \mathrm{E}+00^{\wedge}(\text { axial@ } 1.3 \mathrm{~kW})\end{array}$ & $\begin{array}{c}2.74 \mathrm{E}+00 \\
\text { (prior to IEC) }\end{array}$ & $\begin{array}{l}2.24 \mathrm{E}+00 \text { (radial mode) } \\
2.29 \mathrm{E}+00 \text { (axial mode) }\end{array}$ \\
\hline \multicolumn{4}{|c|}{ SRAT Product } \\
\hline \multicolumn{4}{|c|}{ Digestion Method: PF } \\
\hline & $\mathrm{Th}(\mathrm{Wt} \%)$ & $\mathrm{U}(\mathrm{Wt} \%)$ & $\mathrm{U}(\mathrm{Wt} \%)$ after IEC for Th Interference \\
\hline ICP-MS & $2.37 \mathrm{E}+00$ & $1.80 \mathrm{E}+00^{*}$ & $\mathrm{~N} / \mathrm{A}$ \\
\hline ICP-AES & $\begin{array}{r}2.4 \mathrm{E}+00 \text { (radial mode) } \\
2.3 \mathrm{E}+00 \text { (axial mode) } \\
\end{array}$ & $\begin{array}{c}2.26 \mathrm{E}+00 \\
\text { (prior to IEC) }\end{array}$ & $\begin{array}{l}1.9 \mathrm{E}+00 \text { (radial mode) } \\
1.77 \mathrm{E}+00 \text { (axial mode) }\end{array}$ \\
\hline \multicolumn{4}{|c|}{ Digestion Method: AR } \\
\hline & $\mathrm{Th}(\mathrm{Wt} \%)$ & $\mathrm{U}(\mathrm{Wt} \%)$ & $\mathrm{U}(\mathrm{Wt} \%)$ after IEC for Th Interference \\
\hline ICP-MS & $2.89 \mathrm{E}+00$ & $1.84 \mathrm{E}+00^{*}$ & $\mathrm{~N} / \mathrm{A}$ \\
\hline ICP-AES & $\begin{array}{c}2.69 \mathrm{E}+00 \text { (radial mode) } \\
2.86 \mathrm{E}+00 \text { (axial mode) }\end{array}$ & $\begin{array}{c}2.18 \mathrm{E}+00 \\
\text { (prior to IEC) }\end{array}$ & $\begin{array}{c}1.95 \mathrm{E}+00 \text { (radial mode) } \\
1.99 \mathrm{E}+00 \text { (axial mode) }\end{array}$ \\
\hline \multicolumn{4}{|c|}{ Digestion Method: CC } \\
\hline & $\mathrm{Th}(\mathrm{Wt} \%)$ & $\mathrm{U}(\mathrm{Wt} \%)$ & $\mathrm{U}(\mathrm{Wt} \%)$ after IEC for Th Interference \\
\hline ICP-MS & $2.20 \mathrm{E}+00$ & $1.86 \mathrm{E}+00^{*}$ & $\mathrm{~N} / \mathrm{A}$ \\
\hline ICP-AES & $\begin{array}{c}\text { 3.4E-01 (radial mode) } \\
1.6 \mathrm{E}+00 \text { (axial mode) } \\
2.2 \mathrm{E}+00(\text { axial@1.3kW) }\end{array}$ & $\begin{array}{c}2.22 \mathrm{E}+00 \\
\text { (prior to IEC) }\end{array}$ & $\begin{array}{c}1.99 \mathrm{E}+00 \text { (radial mode) } \\
2.02 \mathrm{E}+00 \text { (axial mode) }\end{array}$ \\
\hline
\end{tabular}

All data presented in Table 3-1 are an average of four replicates unless noted. *ICP-MS results are a sum of only U-238 and U-235 isotopes. ${ }^{\wedge}$ Th data for the SRAT Receipt CC digestions is an average of three results. Results are reported to the first digit of the calculated standard deviation.

Undissolved/precipitated solids are visible in the DWPF CC digestion solutions in each case (SRAT Receipt and SRAT Product). A single SRAT Receipt initial dilution bottle was filtered to recover the visible solids, submitted to $\mathrm{C}$-XRD for analysis and identified as calcium thorium fluoride $\left(\mathrm{Ca}_{0.5} \mathrm{Th}_{0.5} \mathrm{~F}_{3}\right)$. This species most likely formed by reaction with the excess HF added to the sample and precipitated out of solution. Solids from the SRAT Product sample could not be removed from the shielded cells due to the dose rate. Further work is in progress to isolate and wash SRAT product solids to identify the solids and determine if they are different than that observed in the SRAT receipt. Furthermore, undissolved solids were visually observed in the AR digestion solutions of both the SRAT Receipt and SRAT Product 


\section{SRNL-STI-2010-00259, REVISION 0}

digestions. The solids from the SRAT Receipt AR digestions were recovered by filtration, analyzed by $\mathrm{C}$-XRD and identified as boehmite. No undissolved solids were observed in the resulting solutions from the PF digestions. The solids in the AR digestions of the SRAT Product material were not recovered for analysis but assumed to be boehmite based upon the SRAT Receipt solids C-XRD analysis results.

During verification of the DWPF CC method for previous sludge batches, boehmite $(\mathrm{AlO}(\mathrm{OH}))$, muscovite $(\mathrm{K}, \mathrm{Na})(\mathrm{Al}, \mathrm{Mg}, \mathrm{Fe})_{2}\left(\mathrm{Si}_{3.1} \mathrm{Al}_{0.9}\right) \mathrm{O}_{10}(\mathrm{OH})_{2}$, silicon dioxide $\left(\mathrm{SiO}_{2}\right)$, dipotassium sodium aluminum fluoride $\left(\mathrm{K}_{2} \mathrm{NaAl}_{3} \mathrm{~F}_{12}\right)$, dipotassium aluminum pentafluoride $\left(\mathrm{K}_{2} \mathrm{AlF}_{5}\right)$, aluminum fluoride $\left(\mathrm{AlF}_{3}\right)$, chiolite $\left(\mathrm{Na}_{5} \mathrm{Al}_{3} \mathrm{~F}_{14}\right)$, cryolite $\left(\mathrm{Na}_{3} \mathrm{AlF}_{6}\right)$, sodium magnesium aluminum hexafluoride $\left(\mathrm{NaMgAlF}_{6}\right)$, iron zirconium hexafluoride $\left(\mathrm{FeZrF}_{6}\right)$ and disodium iron aluminum heptafluoride $\left(\mathrm{Na}_{2} \mathrm{FeAlF}_{7}\right)$ have been identified as part of the undissolved/precipitated solids. ${ }^{6}$

The statistical results of the SB6 Batch samples generated from this study are provided in Appendix A. The results from each type of digestion are summarized in Table 3-2 - Table 3-3 for the SRAT Receipt and Table 3-4 and Table 3-5 for the SRAT Product samples. The ICP-AES results of the sixteen elements that are currently analyzed by the DWPF lab in addition to Th are presented on a weight percent (Wt\%) of total solids basis. A statistical comparison of means from digestion of SRAT material for all three digestions could not be performed for $\mathrm{B}, \mathrm{Ca}, \mathrm{K}, \mathrm{Na}, \mathrm{Si}$ or $\mathrm{Zr}$. B was less than the detection limit in the $\mathrm{AR}$ and $\mathrm{PF}$ digestions and $\mathrm{B}$ is leached from the borosilicate spray chamber of the ICP-AES instrument due to the presence of $\mathrm{HF}$ in the $\mathrm{CC}$ digestions. $\mathrm{Ca}$ is a contaminant in the PF reagents (the PF blank $\mathrm{Ca}$ concentration was $130 \mu \mathrm{g} / \mathrm{g}$ ) and therefore only the means from the AR and CC digestions were compared. $\mathrm{K}$ was less than the minimum detection limit in the $\mathrm{CC}$ digestions. $\mathrm{Na}$ is added as part of the reagents used for PF digestions. Si could not be compared because it is leached from the ICP-AES instrument due to the presence of $\mathrm{HF}$ in the $\mathrm{CC}$ digestions and $\mathrm{Si}$ is known not to dissolve well in $\mathrm{AR}$ digestions. $\mathrm{Zr}$ could not be included in a statistical comparison of the means because the PF digestion utilizes a $\mathrm{Zr}$ crucible, therefore only the AR and CC results were compared. However, the Zr result from the AR digestions is low. $\mathrm{Zr}$ dissolves better when HF is present and this can readily be seen from the ARG-1 analysis results. Additionally, for the SRAT Product, the Li concentrations could not be compared because $\mathrm{Li}$ was less than the minimum detection limit in the PF and $\mathrm{CC}$ digestions.

Statistical comparisons of the data from the three digestion methods (for $\mathrm{Na}$ and $\mathrm{Zr}$ there are only two digestion methods) are provided in Appendix A. The results were generated using JMP Version 7.0.2. ${ }^{7}$ The plots show a 95\% confidence interval for the mean (a mean diamond) of each set of measurements. For each element, the mean concentration of the samples by each digestion method is provided, and means that are not connected by the same letter in the listing of the exhibit are significantly different. For example consider the SRAT Product Fe measurements. The results of the exhibit indicate that the mean of the $\mathrm{CC}$ results differs from the mean of the PF and AR results.

For the $\mathrm{Na}$ and $\mathrm{Zr}$ comparisons, the JMP output from an analysis of variance of the measurements for two digestions is provided, and only the $95 \%$ confidence mean diamond of each digestion is shown. Overlap marks show for each diamond, and overlap marks in one diamond that are closer to the mean of another diamond than that diamond's overlap marks indicate that those two groups are not different at the $95 \%$ confidence level. The visual comparisons are supported by an $\mathrm{F}$ test that compares the means of the AR and $\mathrm{CC}$ digestions for $\mathrm{Na}$ and $\mathrm{Zr}$ and the means of the $\mathrm{AR}$ and $\mathrm{PF}$ digestions for $\mathrm{Si}$. If the $\mathrm{p}$ value is less than 0.05 , then the means are statistically different at the 5\% level. From the Appendix, there is an indication of a difference in the AR and CC means for $\mathrm{Na}$ for both the SRAT Product and the SRAT Receipt.

Summaries of the statistical comparisons of the Appendix are shown in Table 3-3 and Table 3-5. Following the format used in the exhibit, digestions not having the same letter are statistically different at the 5\% significance level. Consider the SRAT Receipt Fe results, the average mean of Fe measured in the 
PF and AR method digestions are statistically the same (and both columns have the letter A), but these means are statistically different from the mean average obtained from the DWPF CC digestion (which has the letter B in the column). The letter listed for a particular digestion corresponds to the concentration of a particular element in the sample relative to the other digestion methods. For example, a particular digestion method with the letter $\mathrm{A}$ by an element had the highest concentration of those compared, the letter B, the next highest concentration and so on. ARG results are presented and compared for each digestion type for the SRAT Receipt and SRAT Product samples in Table 3-6 - Table 3-9, including a similar statistical comparison of the means comparing the results obtained from all ARG digestions. The statistical analysis of Th for all three digestions was based upon axial and radial mode PF and AR data compared to only the axial mode Th data at $1.3 \mathrm{~kW}$ from the $\mathrm{CC}$ digestions, since the lower wattage measurements were clearly statistically different (see Table 3-1). Statistical comparison of U is presented for all three digestions in both axial and radial mode at $1.1 \mathrm{~kW}$. 
SRNL-STI-2010-00259, REVISION 0

Table 3-2 Elemental concentrations of SB6 SRAT Receipt radioactive sludge slurry obtained from ICP-AES analysis of Aqua Regia, DWPF Cold Chem method and Sodium Peroxide/Hydroxide Fusion digestions. Values are presented on a weight percent $(\mathrm{Wt} \%)$ of total dried solids basis.

\begin{tabular}{|c|c|c|c|c|c|c|}
\hline $\begin{array}{c}\text { Digestion } \\
\text { Method } \rightarrow\end{array}$ & \multicolumn{2}{|c|}{ Aqua Regia } & \multicolumn{2}{c|}{$\mathrm{Na}_{2} \mathrm{O}_{2} / \mathrm{NaOH}$ Fusion } & \multicolumn{2}{c|}{ DWPF Cold Chem } \\
\hline Element & Avg Wt $\% *$ & $\% R S D^{\#}$ & Avg Wt $\%$ & $\% \mathrm{RSD}^{\#}$ & Avg Wt\%* & $\% \mathrm{RSD}^{\#}$ \\
\hline $\mathrm{Al}$ & $1.02 \mathrm{E}+01$ & $1 . \mathrm{E}+00$ & $1.095 \mathrm{E}+01$ & $5 . \mathrm{E}-01$ & $1.04 \mathrm{E}+01$ & $8 . \mathrm{E}+00$ \\
\hline $\mathrm{B}$ & $<6.92 \mathrm{E}-03$ & NA & $<3.50 \mathrm{E}-02$ & NA & NA & NA \\
\hline $\mathrm{Ca}$ & $5.27 \mathrm{E}-01$ & $9 . \mathrm{E}-01$ & $5.8 \mathrm{E}-01$ & $2 . \mathrm{E}+00$ & $5.1 \mathrm{E}-01$ & $2 . \mathrm{E}+00$ \\
\hline $\mathrm{Cr}$ & $4.39 \mathrm{E}-02$ & $7 . \mathrm{E}-01$ & $4.6 \mathrm{E}-02$ & $3 . \mathrm{E}+00$ & $4.4 \mathrm{E}-02$ & $3 . \mathrm{E}+00$ \\
\hline $\mathrm{Cu}$ & $6.97 \mathrm{E}-02$ & $1 . \mathrm{E}+00$ & $7.24 \mathrm{E}-02$ & $9 . \mathrm{E}-01$ & $5.1 \mathrm{E}-02$ & $4 . \mathrm{E}+00$ \\
\hline $\mathrm{Fe}$ & $1.18 \mathrm{E}+01$ & $2 . \mathrm{E}+00$ & $1.18 \mathrm{E}+01$ & $1 . \mathrm{E}+00$ & $1.0 \mathrm{E}+01$ & $2 . \mathrm{E}+00$ \\
\hline $\mathrm{Li}$ & $1.72 \mathrm{E}-02$ & $2 . \mathrm{E}+00$ & $1.9 \mathrm{E}-02$ & $1 . \mathrm{E}+01$ & $1.7 \mathrm{E}-02$ & $8 . \mathrm{E}+00$ \\
\hline $\mathrm{K}$ & $6.0 \mathrm{E}-02$ & $5 . \mathrm{E}+00$ & $3.6 \mathrm{E}-01$ & $1 . \mathrm{E}+01$ & $<1.32 \mathrm{E}-01$ & NA \\
\hline $\mathrm{Mg}$ & $2.16 \mathrm{E}-01$ & $2 . \mathrm{E}+00$ & $2.13 \mathrm{E}-01$ & $9 . \mathrm{E}-01$ & $2.08 \mathrm{E}-01$ & $2 . \mathrm{E}+00$ \\
\hline $\mathrm{Mn}$ & $4.14 \mathrm{E}+00$ & $1 . \mathrm{E}+00$ & $4.17 \mathrm{E}+00$ & $7 . \mathrm{E}-01$ & $3.9 \mathrm{E}+00$ & $2 . \mathrm{E}+00$ \\
\hline $\mathrm{Na}$ & $1.54 \mathrm{E}+01$ & $9 . \mathrm{E}-01$ & NA & NA & $1.47 \mathrm{E}+01$ & $2 . \mathrm{E}+00$ \\
\hline $\mathrm{Ni}$ & $1.69 \mathrm{E}+00$ & $1 . \mathrm{E}+00$ & $1.70 \mathrm{E}+00$ & $1 . \mathrm{E}+00$ & $1.50 \mathrm{E}+00$ & $3 . \mathrm{E}+00$ \\
\hline $\mathrm{Si}$ & $5.2 \mathrm{E}-01$ & $1 . \mathrm{E}+01$ & $7.1 \mathrm{E}-01$ & $3 . \mathrm{E}+00$ & NA & NA \\
\hline $\mathrm{Th}$ (axial mode) & $3.07 \mathrm{E}+00$ & $1 . \mathrm{E}+00$ & $2.79 \mathrm{E}+00$ & $2 . \mathrm{E}+00$ & $2.6 \mathrm{E}+00$ & $1 . \mathrm{E}+01$ \\
\hline $\mathrm{Th}$ (radial mode) & $3.06 \mathrm{E}+00$ & $2 . \mathrm{E}+00$ & $2.85 \mathrm{E}+00$ & $2 . \mathrm{E}+00$ & NA & NA \\
\hline $\mathrm{Ti}$ & $1.58 \mathrm{E}-02$ & $4 . \mathrm{E}+00$ & $1.69 \mathrm{E}-02$ & $2 . \mathrm{E}+00$ & $1.52 \mathrm{E}-02$ & $3 . \mathrm{E}+00$ \\
\hline $\mathrm{U}$ (axial mode) & $2.48 \mathrm{E}+00$ & $1 . \mathrm{E}+00$ & $2.18 \mathrm{E}+00$ & $1 . \mathrm{E}+00$ & $2.29 \mathrm{E}+00$ & $2 . \mathrm{E}+00$ \\
\hline $\mathrm{U}$ (radial mode) & $2.41 \mathrm{E}+00$ & $2 . \mathrm{E}+00$ & $2.31 \mathrm{E}+00$ & $2 . \mathrm{E}+00$ & $2.24 \mathrm{E}+00$ & $3 . \mathrm{E}+00$ \\
\hline $\mathrm{Zr}$ & $1.6 \mathrm{E}-01$ & $7 . \mathrm{E}+00$ & NA & NA & $2.11 \mathrm{E}-01$ & $2 . \mathrm{E}+00$ \\
\hline
\end{tabular}

*All averages are based upon four replicate dissolutions and ICP-AES determinations except for Al from the AR digestions which is based upon three replicates. Values are reported to the first digit of the calculated standard deviation. NA $=$ Not Applicable. ${ }^{\#} \%$ RSD is the percent relative standard deviation for the measurements. 
Table 3-3 Statistical comparison of Aqua Regia, DWPF Cold Chem method and Sodium Peroxide/Hydroxide Fusion digestions of SB6 SRAT Receipt sludge. Digestions not having the same letter are statistically different at the $5 \%$ significance level.

\begin{tabular}{|c|c|c|c|}
\hline Element & $\begin{array}{c}\text { Aqua } \\
\text { Regia Digestion* }\end{array}$ & $\begin{array}{c}\mathrm{Na}_{2} \mathrm{O}_{2} / \\
\mathrm{NaOH} F u s i o n^{2} \\
\text { Digestion* }\end{array}$ & $\begin{array}{c}\text { DWPF Cold } \\
\text { Chem Method } \\
\text { Digestion* }\end{array}$ \\
\hline $\mathrm{Al}$ & $\mathrm{A}$ & $\mathrm{A}$ & $\mathrm{A}$ \\
\hline $\mathrm{B}$ & $<\mathrm{MDL}$ & $<\mathrm{MDL}$ & - \\
\hline $\mathrm{Ca}$ & $\mathrm{B}$ & - & $\mathrm{A}$ \\
\hline $\mathrm{Cr}$ & $\mathrm{A}$ & $\mathrm{A}$ & $\mathrm{A}$ \\
\hline $\mathrm{Cu}$ & $\mathrm{A}$ & $\mathrm{A}$ & $\mathrm{B}$ \\
\hline $\mathrm{Fe}$ & $\mathrm{C}$ & $\mathrm{A}$ & $<\mathrm{MDL}$ \\
\hline $\mathrm{K}$ & $\mathrm{A}$ & $\mathrm{A}$ & $\mathrm{A}$ \\
\hline $\mathrm{Li}$ & $\mathrm{A}$ & $\mathrm{AB}$ & $\mathrm{B}$ \\
\hline $\mathrm{Mg}$ & $\mathrm{A}$ & - & $\mathrm{B}$ \\
\hline $\mathrm{Mn}$ & $\mathrm{A}$ & $\mathrm{A}$ & $\mathrm{B}$ \\
\hline $\mathrm{Na}$ & $\mathrm{B}$ & $\mathrm{B}$ & - \\
\hline $\mathrm{Ni}$ & $\mathrm{A}$ (axial radial) & $\mathrm{AB}$ (axial mode) & $\mathrm{B}$ (axial mode - \\
$\mathrm{Si}$ & $\mathrm{AB}$ (radial mode) & $1.3 \mathrm{~kW}$ ) \\
\hline $\mathrm{Th}$ & $\mathrm{B}$ & $\mathrm{A}$ & $\mathrm{B}$ \\
\hline $\mathrm{Ti}$ & $\mathrm{A}$ (axial mode) & $\mathrm{D}$ (axial mode) & $\mathrm{CD}$ (axial mode) \\
\hline $\mathrm{U}$ & $\mathrm{BC}$ (radial mode) & $\mathrm{CD}$ (radial mode) \\
\hline $\mathrm{Zr}$ & $\mathrm{B}$ & - & $\mathrm{A}$ \\
\hline
\end{tabular}

*Analysis is based on averages from four replicate dissolutions and ICP-AES determinations except for $\mathrm{Al}$ from the $\mathrm{AR}$ digestions, which is based on three measurements. - = Not Applicable. $<\mathrm{MDL}=$ Less than minimum detection limit.

For the SRAT Receipt sample:

- The SRAT Receipt AR and CC digestion solutions contained white visible solids. The PF digestions solutions did not contain visible solids. The undissolved solids from the AR digestions were identified as boehmite from C-XRD analysis. The undissolved solids from the $\mathrm{CC}$ digestions were identified as calcium thorium fluoride $\left(\mathrm{Ca}_{0.5} \mathrm{Th}_{0.5} \mathrm{~F}_{3}\right)$.

- No statistical difference of the means is observed in the Al concentration between the three digestions, indicating the undissolved amount of boehmite in the AR digestions is small or of small enough particle size to be still be analyzed by the ICP-ES.

- A statistical difference of means at the 5\% significance level is noted for $\mathrm{Fe}, \mathrm{Mn}, \mathrm{Na}, \mathrm{Ni}, \mathrm{Th}$ and $\mathrm{U}$ (for the elements greater than $1.0 \mathrm{Wt} \%$ of total solids). Fe, Mn, Na, Ni and Th mean concentrations are lower in the $\mathrm{CC}$ digestions compared to the $\mathrm{AR}$ and $\mathrm{PF}$ digestions.

- The average Fe concentration from the $\mathrm{CC}$ digestions is $\sim 16.5 \%$ lower than the average $\mathrm{Fe}$ concentration in the AR or PF digestions.

- The average Mn concentration from the CC digestions is $\sim 6.4 \%$ lower than the average $\mathrm{Mn}$ concentration from the AR digestions and $\sim 7.1 \%$ lower than the average Mn concentration from the PF digestions. This could have a potential impact on the calculated acid addition amount.

- The average Ni concentration from the $\mathrm{CC}$ digestions is $\sim 11.5 \%$ lower than the average $\mathrm{Ni}$ concentration from the AR digestions and $\sim 12.0 \%$ lower than the average Ni concentration from the PF digestions.

- $\mathrm{Na}$ was not reported for the PF digestions but the average $\mathrm{Na}$ value from the $\mathrm{CC}$ digestion is $\sim 4.7 \%$ lower than the average $\mathrm{Na}$ value from the AR digestions. 
An ICP-AES method was developed at SRNL in response to Th being present in SB6 which also resulted in the awareness that Th interferes with some $\mathrm{U}$ emission lines and an IEC had to be applied to U data. To verify the ICP-AES measurements, samples were analyzed by ICP-MS for both U and Th. The mean Th concentration in the CC digestions is lower $(\sim 7.5 \%-17 \%)$ than the means of both the PF and AR digestions, respectively, as measured by ICP-AES which may be due to the small amount of Th that has precipitated out of solution from the CC digestions which is also indicated by C-XRD analysis. ICP-MS measurements trend in the same direction for Th for each type of digestion. A statistical difference of the means is also observed for the U results (after an IEC has been applied) but the difference between the $\mathrm{AR}$ and $\mathrm{PF}$ digestions relative to the $\mathrm{CC}$ digestions is less than $10 \%$. There is good agreement between the ICP-MS measured U values and the ICP-AES U values once an IEC is applied (see Table 3-1). There is also good agreement between the ICP-AES and ICP-MS measured Th results. The DWPF lab should determine which $T h$ and $U$ lines to use based upon the results presented here, specific instrument resolution, and the plasma power setting (the $\mathrm{CC}$ digestions had to be analyzed at $1.3 \mathrm{~kW}$ versus $1.1 \mathrm{~kW}$ for the PF digestions), and determine their own IEC factor/s.

The means of Mn and Ni from digestion of ARG glass standards using all three digestions are not statistically different. The means of Fe from the CC digestions and PF digestions are not statistically different, though the AR Fe result is lower but not statistically different from the mean of the PF digestions, see Table 3-6. The results from analysis of the multi-element standards (MES) indicate the ICP-AES instrument is operating as expected. Two MES samples were submitted with each digestion set, and in each case the Fe concentration is $\sim 4 \%$ higher than the known Fe concentration for both MES samples with each set (i.e, a total of six MES samples analyzed and the Fe concentration is $\sim 4 \%$ higher than the standard value).

Table 3-4 contains the elemental concentrations of the SB6 SRAT Product sample. 
SRNL-STI-2010-00259, REVISION 0

Table 3-4 Elemental concentrations of SB6 SRAT Product radioactive sludge slurry obtained from ICP-AES analysis of Aqua Regia, DWPF Cold Chem method and Sodium Peroxide/Hydroxide Fusion digestions. Values are presented on a weight percent $(\mathrm{Wt} \%)$ total dried solids basis.

\begin{tabular}{|c|c|c|c|c|c|c|}
\hline $\begin{array}{c}\text { Digestion } \\
\text { Method } \rightarrow\end{array}$ & \multicolumn{2}{|c|}{ Aqua Regia } & \multicolumn{2}{c|}{$\mathrm{Na}_{2} \mathrm{O}_{2} / \mathrm{NaOH}$ Fusion } & \multicolumn{2}{c|}{ DWPF Cold Chem } \\
\hline Element & Avg Wt\%* & $\% \mathrm{RSD}^{\#}$ & Avg Wt$\%$ & $\% \mathrm{RSD}^{\#}$ & Avg Wt\%* & $\% \mathrm{RSD}^{\#}$ \\
\hline $\mathrm{Al}$ & $8.4 \mathrm{E}+00$ & $5 . \mathrm{E}+00$ & $9.13 \mathrm{E}+00$ & $8 . \mathrm{E}-01$ & $8.5 \mathrm{E}+00$ & $1 . \mathrm{E}+00$ \\
\hline $\mathrm{B}$ & $9 . \mathrm{E}-03$ & $1 . \mathrm{E}+01$ & $<3.17 \mathrm{E}-02$ & NA & NA & NA \\
\hline $\mathrm{Ca}$ & $4.3 \mathrm{E}-01$ & $2 . \mathrm{E}+00$ & $5.2 \mathrm{E}-01$ & $6 . \mathrm{E}+00$ & $3.99 \mathrm{E}-01$ & $9 . \mathrm{E}-01$ \\
\hline $\mathrm{Cr}$ & $3.88 \mathrm{E}-02$ & $1 . \mathrm{E}+00$ & $3.8 \mathrm{E}-02$ & $5 . \mathrm{E}+00$ & $3.84 \mathrm{E}-02$ & $5 . \mathrm{E}-01$ \\
\hline $\mathrm{Cu}$ & $5.18 \mathrm{E}-02$ & $2 . \mathrm{E}+00$ & $5.67 \mathrm{E}-02$ & $6 . \mathrm{E}+00$ & $4.76 \mathrm{E}-02$ & $1 . \mathrm{E}+00$ \\
\hline $\mathrm{Fe}$ & $9.5 \mathrm{E}+00$ & $2 . \mathrm{E}+00$ & $9.65 \mathrm{E}+00$ & $9 . \mathrm{E}-01$ & $8.5 \mathrm{E}+00$ & $1 . \mathrm{E}+00$ \\
\hline $\mathrm{Li}$ & $1.55 \mathrm{E}-02$ & $2 . \mathrm{E}+00$ & $<6.4 \mathrm{E}-02$ & NA & $<3.0 \mathrm{E}-02$ & NA \\
\hline $\mathrm{K}$ & $4.9 \mathrm{E}-02$ & $4 . \mathrm{E}+00$ & $5.2 \mathrm{E}-01$ & $9 . \mathrm{E}+00$ & $<8.0 \mathrm{E}-02$ & NA \\
\hline $\mathrm{Mg}$ & $1.71 \mathrm{E}-01$ & $2 . \mathrm{E}+00$ & $1.60 \mathrm{E}-01$ & $3 . \mathrm{E}+00$ & $1.68 \mathrm{E}-01$ & $8 . \mathrm{E}-01$ \\
\hline $\mathrm{Mn}$ & $3.40 \mathrm{E}+00$ & $2 . \mathrm{E}+00$ & $3.38 \mathrm{E}+00$ & $7 . \mathrm{E}-01$ & $3.22 \mathrm{E}+00$ & $8 . \mathrm{E}-01$ \\
\hline $\mathrm{Na}$ & $1.57 \mathrm{E}+01$ & $2 . \mathrm{E}+00$ & NA & NA & $1.508 \mathrm{E}+01$ & $6 . \mathrm{E}-01$ \\
\hline $\mathrm{Ni}$ & $1.38 \mathrm{E}+00$ & $3 . \mathrm{E}+00$ & $1.38 \mathrm{E}+00$ & $9 . \mathrm{E}-01$ & $1.248 \mathrm{E}+00$ & $8 . \mathrm{E}-01$ \\
\hline $\mathrm{Si}$ & $2.8 \mathrm{E}-01$ & $2 . \mathrm{E}+01$ & $6.7 \mathrm{E}-01$ & $4 . \mathrm{E}+00$ & NA & NA \\
\hline $\mathrm{Th}$ (axial mode) & $2.86 \mathrm{E}+00$ & $2 . \mathrm{E}+00$ & $2.3 \mathrm{E}+00$ & $5 . \mathrm{E}+00$ & $2.2 \mathrm{E}+00$ & $9 . \mathrm{E}+00$ \\
\hline $\mathrm{Th}$ (radial mode) & $2.69 \mathrm{E}+00$ & $2 . \mathrm{E}+00$ & $2.4 \mathrm{E}+00$ & $5 . \mathrm{E}+00$ & NA & NA \\
\hline $\mathrm{Ti}$ & $1.44 \mathrm{E}-02$ & $2 . \mathrm{E}+00$ & $1.47 \mathrm{E}-02$ & $2 . \mathrm{E}+00$ & $1.8 \mathrm{E}-02$ & $2.5 \mathrm{E}+01$ \\
\hline $\mathrm{U}$ (axial mode) & $1.99 \mathrm{E}+00$ & $3 . \mathrm{E}+00$ & $1.77 \mathrm{E}+00$ & $4 . \mathrm{E}+00$ & $2.02 \mathrm{E}+00$ & $7 . \mathrm{E}-01$ \\
\hline $\mathrm{U}$ (radial mode) & $1.95 \mathrm{E}+00$ & $4 . \mathrm{E}+00$ & $1.9 \mathrm{E}+00$ & $6 . \mathrm{E}+00$ & $1.99 \mathrm{E}+00$ & $1 . \mathrm{E}+00$ \\
\hline $\mathrm{Zr}$ & $1.7 \mathrm{E}-01$ & $9 . \mathrm{E}+00$ & NA & NA & $1.82 \mathrm{E}-01$ & $1.5 \mathrm{E}+00$ \\
\hline
\end{tabular}

*All averages are based upon four replicate dissolutions and ICP-AES determinations. Values are reported to the first digit of the calculated standard deviation. NA $=$ Not Applicable. ${ }^{\#} \% \mathrm{RSD}$ is the percent relative standard deviation for the measurements. 
Table 3-5 Statistical comparison of Aqua Regia, DWPF Cold Chem method and Sodium Peroxide/Hydroxide Fusion digestions of SB6 SRAT Product sludge. Digestions not having the same letter are statistically different at the $5 \%$ significance level.

\begin{tabular}{|c|c|c|c|}
\hline Element & $\begin{array}{c}\text { Aqua } \\
\text { Regia Digestion* }\end{array}$ & $\begin{array}{c}\mathrm{Na}_{2} \mathrm{O}_{2} / \\
\mathrm{NaOH} \text { Fusion } \\
\text { Digestion* }\end{array}$ & $\begin{array}{l}\text { DWPF Cold } \\
\text { Chem Method } \\
\text { Digestion* }\end{array}$ \\
\hline $\mathrm{Al}$ & $\mathrm{B}$ & $\mathrm{A}$ & $\mathrm{B}$ \\
\hline $\mathrm{B}$ & B & B & - \\
\hline $\mathrm{Ca}$ & $\mathrm{B}$ & $\mathrm{A}$ & $\mathrm{B}$ \\
\hline $\mathrm{Cr}$ & $\mathrm{A}$ & $\mathrm{A}$ & $\mathrm{A}$ \\
\hline $\mathrm{Cu}$ & $\mathrm{B}$ & A & $\mathrm{C}$ \\
\hline $\mathrm{Fe}$ & $\mathrm{A}$ & $\mathrm{A}$ & $\mathrm{B}$ \\
\hline $\mathrm{K}$ & $\mathrm{B}$ & $\mathrm{A}$ & $\mathrm{B}$ \\
\hline $\mathrm{Li}$ & $\mathrm{C}$ & $\mathrm{A}$ & $\mathrm{B}$ \\
\hline $\mathrm{Mg}$ & $\mathrm{A}$ & $\mathrm{B}$ & $\mathrm{A}$ \\
\hline $\mathrm{Mn}$ & $\mathrm{A}$ & $\mathrm{A}$ & $\mathrm{B}$ \\
\hline $\mathrm{Na}$ & A & - & $\mathrm{B}$ \\
\hline $\mathrm{Ni}$ & A & $\mathrm{A}$ & $\mathrm{B}$ \\
\hline $\mathrm{Si}$ & $\mathrm{B}$ & $\mathrm{B}$ & - \\
\hline Th & $\begin{array}{l}\text { A (axial mode) } \\
\text { A (radial mode) }\end{array}$ & $\begin{array}{l}\text { B (axial mode) } \\
\mathrm{B}(\text { radial mode })\end{array}$ & B (axial mode) \\
\hline $\mathrm{Ti}$ & A & A & A \\
\hline $\mathrm{U}$ & $\begin{array}{l}\text { A (axial mode) } \\
\text { A (radial mode) }\end{array}$ & $\begin{array}{c}\text { B (axial mode) } \\
\text { AB (radial mode) }\end{array}$ & $\begin{array}{c}\text { A (axial mode) } \\
\text { AB (radial mode) }\end{array}$ \\
\hline $\mathrm{Zr}$ & A & - & A \\
\hline
\end{tabular}

*All averages are based upon four replicate dissolutions and ICP-AES determinations. NA = Not Applicable. $<\mathrm{MDL}=$ Less than minimum detection limit. - = Not Applicable.

For the SRAT Product sample:

- The SRAT Product AR and CC digestion solutions contained visible white solids. The PF digestions solutions did not contain visible solids.

- A statistical difference in the means is observed for the $\mathrm{Al}$ concentration in the PF digestions compared to both the $\mathrm{AR}$ and $\mathrm{CC}$ digestions. The average $\mathrm{Al}$ concentration in the $\mathrm{CC}$ digestions is $\sim 6.6 \%$ lower than the $\mathrm{PF}$ digestions. The average $\mathrm{Al}$ concentration from the $\mathrm{AR}$ digestions is $\sim 7.7 \%$ lower than the PF digestions.

- A statistical difference of means is also noted for Fe, Mn, Na, Ni and Th whose concentrations are lower in the $\mathrm{CC}$ digestions compared to the $\mathrm{AR}$ and $\mathrm{PF}$ digestions.

- The average Fe concentration from the $\mathrm{CC}$ digestions is $\sim 11.5 \%$ lower than the average $\mathrm{Fe}$ concentration from the AR digestions and $\sim 12.5 \%$ lower than the average Fe concentration from the PF digestions.

- The average Mn concentration from the $\mathrm{CC}$ digestions is $\sim 5.6 \%$ lower than the average $\mathrm{Mn}$ concentration from the AR digestions and $\sim 4.8 \%$ lower than the average Mn concentration from the PF digestions.

- The average Ni concentration from the $\mathrm{CC}$ digestions is $\sim 10.3 \%$ lower than the average $\mathrm{Ni}$ concentration from the AR and $\sim 9.7 \%$ lower than the average from the PF digestions.

- $\mathrm{Na}$ is not reported for the PF digestions but the average $\mathrm{Na}$ value from the $\mathrm{CC}$ digestion is $\sim 4.0 \%$ lower than the average Na value from the AR digestions. 
The mean Th concentration in the CC digestions is lower than the means of both the AR and PF digestions as measured by ICP-AES and ICP-MS which may be due to the small amount of Th that has precipitated out of solution from the $\mathrm{CC}$ digestions. No statistical difference of the means is observed for the $U$ results (after and IEC has been applied) except the mean measurements made in axial mode of the $\mathrm{PF}$ digestions is different than the mean axial mode measurements from the $\mathrm{CC}$ and $\mathrm{AR}$ digestions. The ICP-AES U results are in good agreement with the ICP-MS results once an IEC factor is applied (see Table 3-1), and the Th results are also in good agreement.

The means of $\mathrm{Fe}, \mathrm{Mn}$, and Ni from digestion of ARG glass standards using all three digestions are not statistically different, see Table 3-6. The results from the analysis of the MES indicate the ICP-AES instrument is operating as expected. Two MES samples were submitted with each digestion set, and in each case the Fe concentration is $\sim 1-6 \%$ higher than the known concentration for both MES samples with each set (i.e, a total of six MES samples analyzed and the Fe concentration is $\sim 1-6 \%$ higher that the known value).

Table 3-6 through Table 3-9 contain the ICP-AES measured weight percent elemental results from triplicate digestions of the ARG standard performed concurrently with the SB6 SRAT samples to determine if the dissolutions were complete and the resulting analyses accurate. Comparison to the known elemental weight percent in the ARG standard is also given in Tables 3-6 - 3-9. The statistical comparison is presented for all six ARG digestions performed along with the SRAT Receipt and SRAT Product sludge samples. 
Table 3-6. Elemental concentrations of ARG standard from ICP-AES analysis of Aqua Regia, DWPF Cold Chem method and Sodium Peroxide/Hydroxide Fusion digestions performed concurrently with SB6 SRAT Receipt Sample. Values are presented on a weight percent (Wt\%) total solids basis. Digestions not having the same letter are statistically different at the $5 \%$ significance level.

\begin{tabular}{|c|c|c|c|c|c|c|}
\hline \multicolumn{7}{|c|}{ Aqua Regia* } \\
\hline Element & $\begin{array}{c}\text { Average } \\
\text { Wt \% }\end{array}$ & \%RSD & $\begin{array}{l}\text { Standard } \\
\text { Value }\end{array}$ & \multicolumn{2}{|c|}{$\begin{array}{l}\text { \%Difference (Measured vs } \\
\text { Standard Value) }\end{array}$} & $\begin{array}{c}\text { Statistical Comparison } \\
\text { AR (PF, CC) }\end{array}$ \\
\hline $\mathrm{Al}$ & $2.27 \mathrm{E}+00$ & $2.3 \mathrm{E}+00$ & $2.50 \mathrm{E}+00$ & \multicolumn{2}{|r|}{-9.3} & $\mathrm{~B}(\mathrm{~A}, \mathrm{AB})$ \\
\hline B & $2.45 \mathrm{E}+00$ & $2.7 \mathrm{E}+00$ & $2.69 \mathrm{E}+00$ & \multicolumn{2}{|r|}{-8.9} & $\mathrm{C}(\mathrm{BC},-)$ \\
\hline $\mathrm{Ca}$ & 9.99E-01 & $3.0 \mathrm{E}+00$ & $1.02 \mathrm{E}+00$ & \multicolumn{2}{|r|}{-2.0} & $A(-A B)$ \\
\hline $\mathrm{Cr}$ & $6.16 \mathrm{E}-02$ & $2.7 \mathrm{E}+00$ & $6.40 \mathrm{E}-02$ & \multicolumn{2}{|r|}{-3.8} & $\mathrm{~B}(\mathrm{AB}, \mathrm{A})$ \\
\hline $\mathrm{Cu}$ & $3.00 \mathrm{E}-03$ & $4.3 \mathrm{E}+00$ & $3.00 \mathrm{E}-03$ & \multicolumn{2}{|r|}{0.0} & $\mathrm{E}(\mathrm{DE},<\mathrm{MDL})$ \\
\hline $\mathrm{Fe}$ & $9.26 \mathrm{E}+00$ & $2.6 \mathrm{E}+00$ & $9.79 \mathrm{E}+00$ & \multicolumn{2}{|r|}{-5.4} & $\mathrm{~B}(\mathrm{AB}, \mathrm{A})$ \\
\hline $\mathrm{K}$ & $2.10 \mathrm{E}+00$ & $2.5 \mathrm{E}+00$ & $2.26 \mathrm{E}+00$ & \multicolumn{2}{|r|}{-7.1} & $\mathrm{C}(\mathrm{B}, \mathrm{BC})$ \\
\hline $\mathrm{Li}$ & $1.41 \mathrm{E}+00$ & $2.6 \mathrm{E}+00$ & $1.49 \mathrm{E}+00$ & \multicolumn{2}{|r|}{-5.4} & $\mathrm{~A}(\mathrm{~A}, \mathrm{~A})$ \\
\hline $\mathrm{Mg}$ & $4.86 \mathrm{E}-01$ & $2.7 \mathrm{E}+00$ & $5.20 \mathrm{E}-01$ & & -6.5 & $\mathrm{AB}(\mathrm{AB}, \mathrm{A})$ \\
\hline $\mathrm{Mn}$ & $1.36 \mathrm{E}+00$ & $2.6 \mathrm{E}+00$ & $1.46 \mathrm{E}+00$ & & -7.1 & $\mathrm{~A}(\mathrm{~A}, \mathrm{~A})$ \\
\hline $\mathrm{Na}$ & $8.03 \mathrm{E}+00$ & $2.7 \mathrm{E}+00$ & $8.52 \mathrm{E}+00$ & & -5.8 & $\mathrm{~A}(-, \mathrm{A})$ \\
\hline $\mathrm{Ni}$ & $7.85 \mathrm{E}-01$ & $2.7 \mathrm{E}+00$ & $8.27 \mathrm{E}-01$ & & -5.0 & $\mathrm{~A}(\mathrm{~A}, \mathrm{~A})$ \\
\hline $\mathrm{Si}$ & $8.16 \mathrm{E}-01$ & $3.2 \mathrm{E}+01$ & $2.24 \mathrm{E}+01$ & & -96.4 & NA \\
\hline $\mathrm{Ti}$ & $5.39 \mathrm{E}-01$ & $2.6 \mathrm{E}+00$ & $6.90 \mathrm{E}-01$ & & -21.9 & $\mathrm{C}(\mathrm{A}, \mathrm{A})$ \\
\hline $\mathrm{U}$ & NA & NA & NA & & NA & - \\
\hline $\mathrm{Zr}$ & $5.92 \mathrm{E}-02$ & $1.4 \mathrm{E}+00$ & $9.60 \mathrm{E}-02$ & & -38.4 & $\mathrm{~A}(-, \mathrm{B})$ \\
\hline & & & dium Perox & $\mathrm{e} / \mathrm{Hy}$ & ide Fusion* & \\
\hline Elem & & $\begin{array}{l}\text { Average } \\
\text { Wt } \%\end{array}$ & & & Standard Value & $\begin{array}{l}\text { \%Difference (Measured } \\
\text { vs Standard Value) }\end{array}$ \\
\hline $\mathrm{Al}$ & & $2.53 \mathrm{E}+00$ & & & $2.50 \mathrm{E}+00$ & 1.1 \\
\hline B & & $2.60 \mathrm{E}+00$ & & & $2.69 \mathrm{E}+00$ & -3.5 \\
\hline $\mathrm{Ca}$ & & $1.14 \mathrm{E}+00$ & & & $1.02 \mathrm{E}+00$ & 12.1 \\
\hline $\mathrm{Cr}$ & & $6.58 \mathrm{E}-02$ & & & $6.40 \mathrm{E}-02$ & 2.8 \\
\hline $\mathrm{Cu}$ & & $4.31 \mathrm{E}-03$ & & & $3.00 \mathrm{E}-03$ & 43.7 \\
\hline $\mathrm{Fe}$ & & $9.80 \mathrm{E}+00$ & & & $9.79 \mathrm{E}+00$ & 0.1 \\
\hline $\mathrm{K}$ & & $2.37 \mathrm{E}+00$ & & & $2.26 \mathrm{E}+00$ & 5.0 \\
\hline $\mathrm{Li}$ & & $1.45 \mathrm{E}+00$ & & & $1.49 \mathrm{E}+00$ & -2.9 \\
\hline $\mathrm{Mg}_{\xi}$ & & $5.25 \mathrm{E}-01$ & & +00 & $5.20 \mathrm{E}-01$ & 1.0 \\
\hline $\mathrm{Mr}$ & & $1.44 \mathrm{E}+00$ & & +00 & $1.46 \mathrm{E}+00$ & -1.4 \\
\hline $\mathrm{Na}$ & & NA & & & $8.52 \mathrm{E}+00$ & NA \\
\hline $\mathrm{Ni}$ & & $8.29 \mathrm{E}-01$ & & +00 & $8.27 \mathrm{E}-01$ & 0.2 \\
\hline $\mathrm{Si}$ & & $2.07 \mathrm{E}+01$ & & +00 & $2.24 \mathrm{E}+01$ & -7.6 \\
\hline $\mathrm{Ti}$ & & $6.92 \mathrm{E}-01$ & & +00 & $6.90 \mathrm{E}-01$ & 0.2 \\
\hline $\mathrm{U}$ & & NA & & & NA & NA \\
\hline $\mathrm{Zr}$ & & NA & & & $9.60 \mathrm{E}-02$ & NA \\
\hline
\end{tabular}

*All averages are based upon three replicate dissolutions and ICP-AES determinations. NA $=$ Not applicable. - = Not applicable for statistical comparison. 
Table 3-7. Continuation of elemental concentrations of ARG standard from ICP-AES analysis of Aqua Regia, DWPF Cold Chem method and Sodium Peroxide/Hydroxide Fusion digestions performed concurrently with SB6 SRAT Receipt Sample. Values are presented on a weight percent $(\mathrm{Wt} \%)$ total solids basis.

\begin{tabular}{|c|c|c|c|c|}
\hline \multicolumn{5}{|c|}{ DWPF Cold Chem Method* } \\
\hline Element & Average & \%RSD & Standard Value & $\begin{array}{c}\text { \%Difference (Measured } \\
\text { vs Standard Value) }\end{array}$ \\
\hline $\mathrm{Al}$ & $2.46 \mathrm{E}+00$ & $6.1 \mathrm{E}+00$ & $2.50 \mathrm{E}+00$ & -1.7 \\
\hline $\mathrm{B}$ & $2.81 \mathrm{E}+00$ & $1.1 \mathrm{E}+00$ & $2.69 \mathrm{E}+00$ & 4.5 \\
\hline $\mathrm{Ca}$ & $1.06 \mathrm{E}+00$ & $8.3 \mathrm{E}+00$ & $1.02 \mathrm{E}+00$ & 4.3 \\
\hline $\mathrm{Cr}$ & $6.96 \mathrm{E}-02$ & $6.7 \mathrm{E}+00$ & $6.40 \mathrm{E}-02$ & NA \\
\hline $\mathrm{Cu}$ & $<6.14 \mathrm{E}-03$ & NA & $3.00 \mathrm{E}-03$ & 5.4 \\
\hline $\mathrm{Fe}$ & $1.03 \mathrm{E}+01$ & $5.0 \mathrm{E}+00$ & $9.79 \mathrm{E}+00$ & -1.0 \\
\hline $\mathrm{K}$ & $2.24 \mathrm{E}+00$ & $5.4 \mathrm{E}+00$ & $2.26 \mathrm{E}+00$ & 1.1 \\
\hline $\mathrm{Li}$ & $1.51 \mathrm{E}+00$ & $6.0 \mathrm{E}+00$ & $1.49 \mathrm{E}+00$ & 3.5 \\
\hline $\mathrm{Mg}$ & $5.38 \mathrm{E}-01$ & $7.0 \mathrm{E}+00$ & $5.20 \mathrm{E}-01$ & 2.1 \\
\hline $\mathrm{Mn}$ & $1.49 \mathrm{E}+00$ & $5.7 \mathrm{E}+00$ & $1.46 \mathrm{E}+00$ & 4.1 \\
\hline $\mathrm{Na}$ & $8.87 \mathrm{E}+00$ & $6.0 \mathrm{E}+00$ & $8.52 \mathrm{E}+00$ & -0.7 \\
\hline $\mathrm{Ni}$ & $8.21 \mathrm{E}-01$ & $5.1 \mathrm{E}+00$ & $8.27 \mathrm{E}-01$ & 50.1 \\
\hline $\mathrm{Si}$ & $3.36 \mathrm{E}+01$ & $2.3 \mathrm{E}+00$ & $2.24 \mathrm{E}+01$ & 0.9 \\
\hline $\mathrm{Ti}$ & $6.96 \mathrm{E}-01$ & $5.1 \mathrm{E}+00$ & $6.90 \mathrm{E}-01$ & NA \\
\hline $\mathrm{U}$ & NA & NA & NA & 1.1 \\
\hline $\mathrm{Zr}$ & $9.71 \mathrm{E}-02$ & $5.4 \mathrm{E}+00$ & $9.60 \mathrm{E}-02$ & \\
\hline
\end{tabular}

*All averages are based upon three replicate dissolutions and ICP-AES determinations NA = Not applicable. $<\mathrm{MDL}=$ less than minimum detection limit. 
Table 3-8. Elemental concentrations of ARG standard from ICP-AES analysis of Aqua Regia, DWPF Cold Chem method and Sodium Peroxide/Hydroxide Fusion digestions performed concurrently with SB6 SRAT Product sample. Values are presented on a weight percent (Wt\%) total solids basis.

\begin{tabular}{|c|c|c|c|c|c|c|}
\hline \multicolumn{7}{|c|}{ Aqua Regia* } \\
\hline Element & Average & \%RSD & $\begin{array}{l}\text { Standard } \\
\text { Value }\end{array}$ & \multicolumn{2}{|c|}{$\begin{array}{c}\text { \%Difference (Measured vs } \\
\text { Standard Value) }\end{array}$} & $\begin{array}{c}\text { Statistical Comparison } \\
\text { AR (PF, CC) }\end{array}$ \\
\hline $\mathrm{Al}$ & $2.46 \mathrm{E}+00$ & $2.7 \mathrm{E}+00$ & $2.50 \mathrm{E}+00$ & & -1.7 & $\mathrm{AB}(\mathrm{AB}, \mathrm{AB})$ \\
\hline B & $2.66 \mathrm{E}+00$ & $2.3 \mathrm{E}+00$ & $2.69 \mathrm{E}+00$ & & -1.1 & $\mathrm{AB}(\mathrm{BC},-)$ \\
\hline $\mathrm{Ca}$ & $1.01 \mathrm{E}+00$ & $1.3 \mathrm{E}+00$ & $1.02 \mathrm{E}+00$ & & -1.4 & $\mathrm{~B}(-, \mathrm{B})$ \\
\hline $\mathrm{Cr}$ & $6.64 \mathrm{E}-02$ & $1.7 \mathrm{E}+00$ & $6.40 \mathrm{E}-02$ & & 3.7 & $\mathrm{AB}(\mathrm{AB}, \mathrm{AB})$ \\
\hline $\mathrm{Cu}$ & $<1.11 \mathrm{E}-02$ & NA & $3.00 \mathrm{E}-03$ & & NA & - all $<$ MDL \\
\hline $\mathrm{Fe}$ & $9.88 \mathrm{E}+00$ & $2.1 \mathrm{E}+00$ & $9.79 \mathrm{E}+00$ & & 0.9 & $\mathrm{AB}(\mathrm{AB}, \mathrm{AB})$ \\
\hline $\mathrm{K}$ & $2.28 \mathrm{E}+00$ & $1.5 \mathrm{E}+00$ & $2.26 \mathrm{E}+00$ & & 0.9 & $\mathrm{BC}(\mathrm{A}, \mathrm{BC})$ \\
\hline $\mathrm{Li}$ & $1.51 \mathrm{E}+00$ & $1.0 \mathrm{E}+00$ & $1.49 \mathrm{E}+00$ & & 1.6 & $\mathrm{~A}(\mathrm{~A}, \mathrm{~A})$ \\
\hline $\mathrm{Mg}$ & $5.20 \mathrm{E}-01$ & $1.8 \mathrm{E}+00$ & $5.20 \mathrm{E}-01$ & & 0.1 & $\mathrm{AB}(\mathrm{AB}, \mathrm{B})$ \\
\hline $\mathrm{Mn}$ & $1.46 \mathrm{E}+00$ & $2.4 \mathrm{E}+00$ & $1.46 \mathrm{E}+00$ & & 0.2 & $\mathrm{~A}(\mathrm{~A}, \mathrm{~A})$ \\
\hline $\mathrm{Na}$ & $8.68 \mathrm{E}+00$ & $2.3 \mathrm{E}+00$ & $8.52 \mathrm{E}+00$ & & 1.9 & $\mathrm{~A}(-, \mathrm{A})$ \\
\hline $\mathrm{Ni}$ & $8.25 \mathrm{E}-01$ & $2.1 \mathrm{E}+00$ & $8.27 \mathrm{E}-01$ & & -0.2 & $\mathrm{~A}(\mathrm{~A}, \mathrm{~A})$ \\
\hline $\mathrm{Si}$ & $6.72 \mathrm{E}-01$ & $6.8 \mathrm{E}+01$ & $2.24 \mathrm{E}+01$ & & -97.0 & - \\
\hline $\mathrm{Ti}$ & $6.07 \mathrm{E}-01$ & $2.5 \mathrm{E}+00$ & $6.90 \mathrm{E}-01$ & & -12.0 & $\mathrm{~B}(\mathrm{~A}, \mathrm{AB})$ \\
\hline $\mathrm{U}$ & NA & NA & NA & & NA & - \\
\hline $\mathrm{Zr}$ & $5.81 \mathrm{E}-02$ & $2.6 \mathrm{E}+00$ & $9.60 \mathrm{E}-02$ & & -39.5 & $\mathrm{~A}(-, \mathrm{B})$ \\
\hline \multicolumn{7}{|c|}{ Sodium Peroxide/Hydroxide Fusion* } \\
\hline \multicolumn{2}{|c|}{ Element } & Average & \multicolumn{2}{|c|}{ \%RSD } & Standard Value & $\begin{array}{l}\text { \%Difference (Measured } \\
\text { vs Standard Value) }\end{array}$ \\
\hline \multicolumn{2}{|c|}{$\mathrm{Al}$} & $2.48 \mathrm{E}+00$ & \multicolumn{2}{|c|}{$2.7 \mathrm{E}+00$} & $2.50 \mathrm{E}+00$ & -0.9 \\
\hline \multicolumn{2}{|c|}{$\mathrm{B}$} & $2.51 \mathrm{E}+00$ & \multicolumn{2}{|c|}{$2.8 \mathrm{E}+00$} & $2.69 \mathrm{E}+00$ & -6.7 \\
\hline \multicolumn{2}{|c|}{$\mathrm{Ca}$} & $1.15 \mathrm{E}+00$ & \multicolumn{2}{|c|}{$5.01 \mathrm{E}-01$} & $1.02 \mathrm{E}+00$ & 13.1 \\
\hline $\mathrm{Cr}$ & & $6.49 \mathrm{E}-02$ & & +00 & $6.40 \mathrm{E}-02$ & 1.4 \\
\hline $\mathrm{Cu}$ & & $<2.04 \mathrm{E}-02$ & & & $3.00 \mathrm{E}-03$ & NA \\
\hline $\mathrm{Fe}$ & & $9.71 \mathrm{E}+00$ & & +00 & $9.79 \mathrm{E}+00$ & -0.8 \\
\hline K & & $2.64 \mathrm{E}+00$ & & +00 & $2.26 \mathrm{E}+00$ & 16.8 \\
\hline $\mathrm{Li}$ & & $1.48 \mathrm{E}+00$ & & +00 & $1.49 \mathrm{E}+00$ & -0.9 \\
\hline $\mathrm{Mg}$ & & $5.14 \mathrm{E}-01$ & & +00 & $5.20 \mathrm{E}-01$ & -1.1 \\
\hline $\mathrm{Mn}$ & & $1.42 \mathrm{E}+00$ & 2.7 & +00 & $1.46 \mathrm{E}+00$ & -2.5 \\
\hline $\mathrm{Ni}$ & & $8.19 \mathrm{E}-01$ & & +00 & $8.27 \mathrm{E}-01$ & -0.9 \\
\hline $\mathrm{Si}$ & & $2.1 .4 \mathrm{E}+01$ & 7.3 & +00 & $2.24 \mathrm{E}+01$ & -4.5 \\
\hline $\mathrm{Ti}$ & & $6.77 \mathrm{E}-01$ & 3.1 & +00 & $6.90 \mathrm{E}-01$ & -2.9 \\
\hline $\mathrm{U}$ & & NA & & A & NA & NA \\
\hline $\mathrm{Zr}$ & & NA & & & $9.60 \mathrm{E}-02$ & NA \\
\hline
\end{tabular}

*All averages are based upon three replicate dissolutions and ICP-AES determinations NA = Not applicable, - = Not applicable for statistical comparison. 
Table 3-9. Continuation of elemental concentrations of ARG standard from ICP-AES analysis of Aqua Regia, DWPF Cold Chem method and Sodium Peroxide/Hydroxide Fusion digestions performed concurrently with SB6 SRAT Product sample. Values are presented on a weight percent (Wt\%) total solids basis.

\begin{tabular}{|c|c|c|c|c|}
\hline \multicolumn{5}{|c|}{ DWPF Cold Chem Method* } \\
\hline Element & Average & \%RSD & Standard Value & $\begin{array}{c}\text { \%Difference (Measured } \\
\text { vs Standard Value) }\end{array}$ \\
\hline $\mathrm{Al}$ & $2.32 \mathrm{E}+00$ & $3.4 \mathrm{E}+00$ & $2.50 \mathrm{E}+00$ & -7.2 \\
\hline $\mathrm{B}$ & $2.62 \mathrm{E}+00$ & $4.4 \mathrm{E}+00$ & $2.69 \mathrm{E}+00$ & -2.5 \\
\hline $\mathrm{Ca}$ & $9.51 \mathrm{E}-01$ & $4.4 \mathrm{E}+00$ & $1.02 \mathrm{E}+00$ & -6.7 \\
\hline $\mathrm{Cr}$ & $6.48 \mathrm{E}-02$ & $3.8 \mathrm{E}+00$ & $6.40 \mathrm{E}-02$ & 1.3 \\
\hline $\mathrm{Cu}$ & $<5.80 \mathrm{E}-03$ & NA & $3.00 \mathrm{E}-03$ & NA \\
\hline $\mathrm{Fe}$ & $9.50 \mathrm{E}+00$ & $4.0 \mathrm{E}+00$ & $9.79 \mathrm{E}+00$ & -3.0 \\
\hline $\mathrm{K}$ & $2.12 \mathrm{E}+00$ & $4.4 \mathrm{E}+00$ & $2.26 \mathrm{E}+00$ & -6.3 \\
\hline $\mathrm{Li}$ & $1.41 \mathrm{E}+00$ & $3.5 \mathrm{E}+00$ & $1.49 \mathrm{E}+00$ & -5.4 \\
\hline $\mathrm{Mg}$ & $4.81 \mathrm{E}-01$ & $3.9 \mathrm{E}+00$ & $5.20 \mathrm{E}-01$ & -4.4 \\
\hline $\mathrm{Mn}$ & $1.39 \mathrm{E}+00$ & $3.7 \mathrm{E}+00$ & $1.46 \mathrm{E}+00$ & -2.2 \\
\hline $\mathrm{Na}$ & $8.34 \mathrm{E}+00$ & $3.6 \mathrm{E}+00$ & $8.52 \mathrm{E}+00$ & -8.5 \\
\hline $\mathrm{Ni}$ & $7.57 \mathrm{E}-01$ & $4.1 \mathrm{E}+00$ & $8.27 \mathrm{E}-01$ & 47.0 \\
\hline $\mathrm{Si}$ & $3.29 \mathrm{E}+01$ & $6.0 \mathrm{E}+00$ & $2.24 \mathrm{E}+01$ & -4.0 \\
\hline $\mathrm{Ti}$ & $6.62 \mathrm{E}-01$ & $3.7 \mathrm{E}+00$ & $6.90 \mathrm{E}-01$ & $\mathrm{NA}$ \\
\hline $\mathrm{Z}$ & $\mathrm{NA}$ & $\mathrm{NA}$ & $\mathrm{NA}$ & -2.6 \\
\hline
\end{tabular}

*All averages are based upon three replicate dissolutions and ICP-AES determinations NA $=$ Not applicable. $<\mathrm{MDL}=$ less than minimum detection limit.

Very good recoveries are observed for nearly all elements of significant weight percent in the ARG standards where appropriate. The low results observed for Fe, Mn and Ni in the CC digestions of the SB6 SRAT Receipt and SRAT Product are not mirrored in the ARG results potentially indicating problems with the digestion of the sludge matrix.

\section{Hg Analysis}

Mercury (Hg) was analyzed according to the outline in the experimental section and in a similar manner to that of the DWPF lab. Table 3-10 summarizes the results from analysis of the SB6 SRAT Receipt.

Table 3-10. CV Hg AA results of digested SB6 SRAT Receipt using the DWPF method and an Aqua Regia digestion for comparison. Values are presented on a weight percent (Wt\%) total dried solids basis and $\%$ RSD is given in parentheses.

\begin{tabular}{|c|c|c|}
\hline Digestion Method & $\begin{array}{c}\text { Measured Hg } \\
\text { Concentration (Wt } \%)\end{array}$ & $\begin{array}{c}\text { \% Difference (DWPF Method } \\
\text { vs Aqua Regia) }\end{array}$ \\
\hline DWPF Method & $3.851(0.2)$ & $\sim 21 \%$ \\
\hline Aqua Regia & $3.21(6.7)$ & $\sim$ \\
\hline
\end{tabular}

The mean DWPF Hg digestion method $\mathrm{Hg}$ value is $\sim 21 \%$ higher than the mean value obtained using the AR digestion method. EPA method 7471B notes that either an aqua regia digestion or the mixture of oxidizing acids used in the DWPF method suffices for Hg analysis. The reason for the discrepancy between the methods is unknown, but it appears that the DWPF method is adequately digesting the $\mathrm{Hg}$ in SB6 sludge slurry. 


\subsection{CONCLUSIONS}

The results presented in this memo document potential issues with the DWPF CC method and the accuracy of this digestion for certain elements contained in SB6. The relatively large difference observed between the CC digestions versus the AR and PF digestions for Fe, Mn and Ni, indicate the DWPF CC digestion may not be solubilizing these elements completely or perhaps they are precipitating out of solution as part of a fluoride salt. No statistical difference of the means for Mn or Ni was observed in the ARG glass digestions. The mean Fe concentration from AR digestion of the ARG standards digested with the SRAT Receipt was slightly low whereas the mean Fe concentration from digestion of the ARG standard with the $\mathrm{CC}$ method was slightly high leading to a statistical difference. The reason for a statistical difference in the means of the Al concentration in the SRAT Product and not in the SRAT Receipt is unclear. Visible solids were seen in the AR and CC digestions of both the SRAT Receipt sample and SRAT Product samples. For the SRAT receipt samples, the visible solids in the digestion solutions were identified as calcium thorium fluoride $\left(\mathrm{Ca}_{0.5} \mathrm{Th}_{0.5} \mathrm{~F}_{3}\right)$. A Th method was developed for the Leeman Prodigy ICP and it was found that Th interferes with U leading to re-analysis and an IEC being applied to $\mathrm{U}$ data.

The peroxide fusion digestion method is the best method for digesting aluminum species that are sparingly soluble in acid. Furthermore, the PF could also be used for the quantification of Fe, Mn, Ni and Th with nitric acid uptake and the addition of hydrogen peroxide. 
This page intentionally left blank 


\subsection{RECOMMENDATIONS}

The following short and long-term recommendations are based upon results from three digestion methods tested at SRNL for SB6 SRAT Receipt and SRAT Product material:

- A dissolution study should be performed on the SB6 WAPS sample by SRNL, which consists of the final composition of the sludge (the SB6 Blend), to determine if the Fe, Mn, Ni and Th concentrations are consistently lower in the $\mathrm{CC}$ digestions versus the $\mathrm{AR}$ and $\mathrm{PF}$ methods for SB6.

- Given the problems seen with measuring Al by the CC method for SB5 and that a SB5 heel remains in Tank 40, the DWPF lab should monitor the Al concentration in the first 10 SRAT Receipt batches of SB6 using both CC and PF methods to evaluate the adequacy of Al recovery by the CC method for SB6.

- Given the statistical difference and high relative difference in the means for Fe, Mn, Ni, and Th, the DWPF lab should also monitor these elements in the first 10 SRAT Receipt batches of SB6 using both the $\mathrm{CC}$ and $\mathrm{PF}$ methods to evaluate the adequacy of recovery by the $\mathrm{CC}$ method for SB6.

- The DWPF lab should establish an ICP-AES method to measure Th, determine which U emission lines are appropriate and determine if an IEC needs to be applied to $U$ data due to the presence of Th, using this report only as a guide.

- The DWPF CC method was originally developed to be used for SME analyses. Given continuous visual observations of solids in the CC digestions both at SRNL and DWPF, potential issues with accurate $\mathrm{Al}$ measurements when processing HM waste, and the results of this report, the DWPF lab should consider a different digestion scheme that relieves some of these issues. Other digestion methods have been developed at SRNL targeting the DWPF lab's process sample analysis.(Need Chucks references)

- The impact of the results of this study need to be assessed against the blending spreadsheet used in DWPF for predicting the glass processing properties to determine the potential impact on SME acceptability. Specifically, the DWPF should compare SRAT blending projections to the SME product results. If the difference in elemental concentrations is significant, another type of digestion (i.e. sodium peroxide/hydroxide fusion) should be used to determine the concentration of the element in question. Additional emphasis should be placed on monitoring $\mathrm{Al}, \mathrm{Fe}, \mathrm{Ni}$ and Th concentrations in SB6 and in particular the Mn concentration which could have a potential impact on the calculated acid addition amount. 
This page intentionally left blank 


\subsection{REFERENCES}

1. C.J. Bannochie, J.M. Pareizs, N.E. Bibler, C.C. Herman, B.N. Attaway, L.H. Connelly, "Qualification of DWPF Sludge Batch 6 and Characterization of Tank 4 Samples in the SRNL Shielded Cells: Analytical Study Plan", SRNL-RP-2009-00474 and TTR referenced within (HLE-TTR-2009-103 Rev. 0, HLW-DWPF-TTR-2009-0014 Rev. 0).

2. C.J. Coleman, T.B. Edwards, M.A. Jones, D.R. Best, "Development of Improved Dissolution Method for Elemental Analysis of DWPF SRAT Samples”, SRNS-STI-2009-00470 Rev. 0.

3. C.J. Coleman, "Alkali Fusion Dissolutions of Sludge and Glass for Elemental and Anion Analysis", ADS Procedure ADS-2502, Rev. 6.

4. C.J. Coleman, "Aqua Regia Dissolution of Sludge for Elemental Analysis", ADS Procedure ADS-2226, Rev. 9.

5. M.S. Hay, J.M. Pareizs, C.J. Bannochie, M.E. Stone, D.R. Click and D.J. McCabe, "Characterization and Aluminum Dissolution Demonstration With A 3 Liter Tank 51H Sample," WSRC-STI-2007-00697, Rev. 0; J.A. Pike, "Preliminary Results for Low Temperature Aluminum Removal from Sludge Batch 5," LWO-LWE-2008-00067 Rev. 0; J.A. Pike and J.M. Gillam, "Flowsheet for Aluminum Removal from Sludge Batch 5," LWO-PIT-2007-00042 Rev. 2.

6. C.J. Coleman, F.M. Pennebaker, B.H. Burch and D.R. Click, "Evaluation of the DWPF Cold Chem Dissolution Method with DWPF Sludge Batch 3 Simulant", WSRC-TR-02-00496, Rev. 0. See also D.R. Click, "Evaluation of the DWPF Cold Chem Dissolution Method with Tank 7 and Tank 51 Radioactive Sludges", WSRC-TR-2003-00580. D.R. Click, C.J. Coleman, K.E. Zeigler and T.B. Edwards, "Sludge Batch Four (4) Defense Waste Processing Facility (DWPF) Process Analytical Method Verification", WSRC-STI-2006-00025 Rev. 0. D.R. Click, H.M. Ajo, T.B. Edwards, "Defense Waste Processing Facility (DWPF) Analytical Method Verification for the Sludge Batch 5 Qualification Sample", SRNS-STI-2008-00090 Rev. 0.

7. JMP Statistical Discovery Software Version 7.0.2; SAS Institute Inc., Cary, NC, 2007. 
This page intentionally left blank 


\subsection{ACKNOWLEDGEMENTS}

The authors would like to acknowledge Ramona Galloway, Monica Jenkins, Rita Sullivan, Loretta Farrow, and Adrienne Williams for help in making this work possible. 
This page intentionally left blank 


\subsection{APPENDIX A. SUPPORTING INFORMATION}


Oneway Analysis of Measurement (Wt\%) By Prep Method Sample=ARG, Element=A

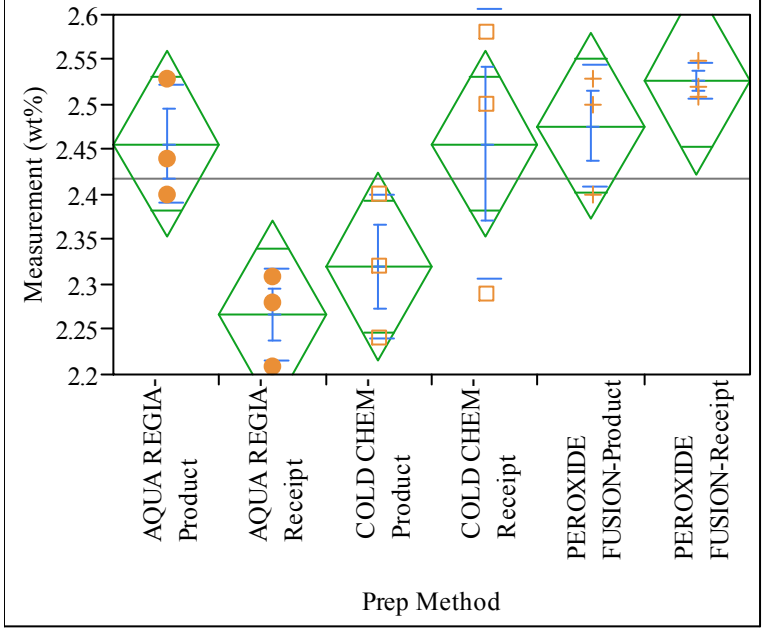

\section{Oneway Anova}

\section{Summary of Fit}

Rsquare

0.650098

Root Mean Square Error $\quad 0.08263$

0.504306

Mean of Respons

2.417222
18

Analysis of Variance

DF Sum of Squares Mean Square F Ratio Prob >

$\begin{array}{lrrrrr}\text { Prep Method } & 5 & 0.15222778 & 0.030446 & 4.4591 & 0.0158\end{array}$

$\begin{array}{llll}\text { Error } & 12 & 0.08193333 & 0.006828 \\ \text { C. Total } & 17 & 0.23416111 & \end{array}$

Means for Oneway Anova

Level

Number Mean Std Error Lower 95\% Upper 95\%

AQUA REGIA-Receip

COLD CHEM-Produc

COLD CHEM-Receipt

$$
\begin{array}{lll}
3 & 2.45667 & 0.04771 \\
3 & 2.26667 & 0.04771
\end{array}
$$

$2.3527 \quad 2.5606$

$2.26667 \quad 0.04771$

$\begin{array}{ll}2.1627 & 2.3706 \\ 2.2161 & 2.4239\end{array}$

PEROXIDE FUSION-Product

$2.32007 \quad 0.04771$

$2.3527-2.5606$

EROXIDE FUSION-Recei

$\begin{array}{ll}2.47667 & 0.04771 \\ 3 & 0.52667 \\ 0.04771\end{array}$

$2.3727 \quad 2.5806$

Std Error uses a pooled estimate of error variance

\section{Means and Std Deviations}

Leve

AQUA REGIA-Product

AQUA REGIA-Receipt

$\begin{array}{rrrrrr}\text { Number } & \text { Mean } & \text { Std Dev } & \text { Std Err Mean } & \text { Lower 95\% } & \text { Upper 95\% } \\ 3 & 2.45667 & 0.066583 & 0.03844 & 2.2913 & 2.6221\end{array}$

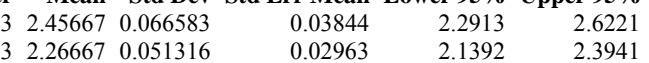

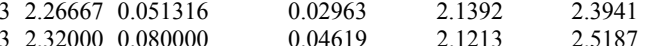

$\begin{array}{lrrrrrr}\text { Level } & \text { Number } & \text { Mean } & \text { Std Dev } & \text { Std Err Mean } & \text { Lower 95\% } & \text { Upper 95\% } \\ \text { COLD CHEM-Receipt } & 3 & 2.45667 & 0.149778 & 0.08647 & 2.0846 & 2.8287\end{array}$

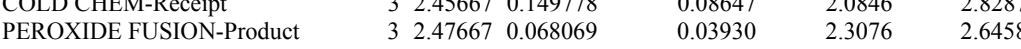

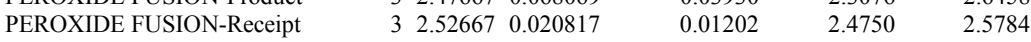

Tests that the Variances are Equa

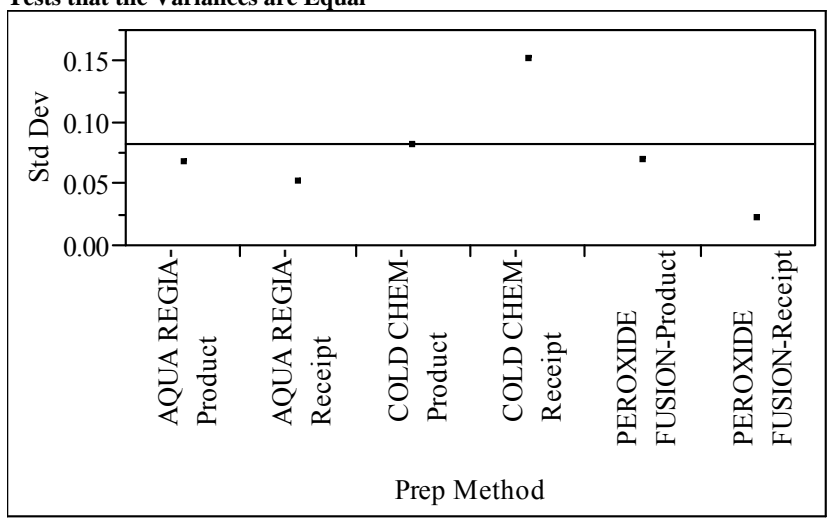

Level

AQUA REGIA-Product

AQUA REGIA-Receipt

COLD CHEM-Product

Count Std Dev MeanAbsDif to Mean MeanAbsDif to Median

COLD CHEM-Receipt

30.0513160

0.0488889

0.0566667

PEROXIDE FUSION-Pro

$\begin{array}{lll}\text { PEROXIDE FUSION-Product } & 3 & 0.0680686 \\ \text { PEROXIDE FUSION-Receipt } & 3 & 0.0208167\end{array}$

0.0533333

0.0800000

30.1497776

0.111111

0.1233333

0.0155556

Test F Ratio DFNum DFDen Prob $>$ F

$\begin{array}{lllll}\text { O'Brien[.5] } & 1.1261 & 5 & 12 & 0.3978 \\ & 2.7072 & 5 & 12 & 0.0731\end{array}$

$\begin{array}{lllll}\text { Brown-Forsythe } & 2.7072 & 5 & 12 & 0.0731 \\ \text { Levene } & 2.2159 & 5 & 12 & 0.1202\end{array}$

$\begin{array}{lllll}\text { Levene } & 2.2159 & 5 & 12 & 0.1202 \\ \text { Bartlett } & 1.1402 & 5 & . & 0.3364\end{array}$

Warning: Small sample sizes. Use Caution.

Welch Anova testing Means Equal, allowing Std Devs Not Equal

\section{F Ratio DFNum DFDen Prob $>$ F}

10.4763

\section{Means Comparisons}

Comparisons for all pairs using Tukey-Kramer HSD

Level

PEROXIDE FUSION-Receipt A $\quad 2.5266667$

PEROXIDE FUSION-Product A B 2.4766667

AQUA REGIA-Product $\quad$ A B 2.4566667

COLD CHEM-Receipt A B 2.4566667

COLD CHEM-Product $\quad$ A B 2.3200000 
Levels not connected by same letter are significantly different.

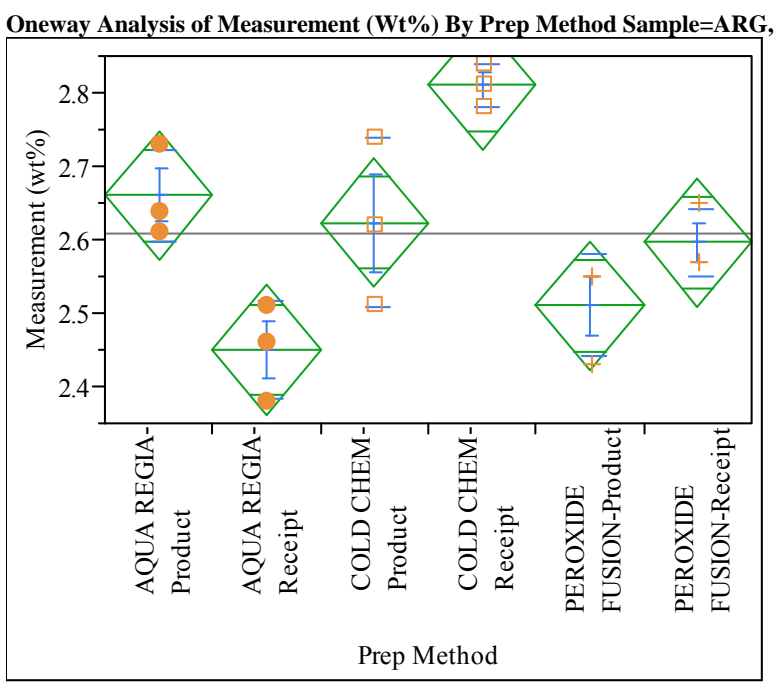

Oneway Anova

Summary of Fit

$\begin{array}{lr}\text { Rsquare } & 0.800805 \\ \text { Adj Rsquare } & 0.717808 \\ \text { Root Mean Square Error } & 0.069841 \\ \text { Mean of Response } & 2.608333 \\ \text { Observations (or Sum Wgts) } & 18\end{array}$

\section{Analysis of Variance}

Source DF Sum of Squares Mean Square F Ratio Prob > F

$\begin{array}{lrllll}\text { Prep Method } & 5 & 0.23531667 & 0.047063 & 9.6485 & 0.0007\end{array}$

$\begin{array}{lrrr}\text { Prep Method } & 5 & 0.23585667 & 0.047063 \\ \text { Error } & 12 & 0.0583333 & 0.004878 \\ \text { C. Total } & 17 & 0.29385000 & \end{array}$

Means for Oneway Anova

\begin{tabular}{|c|c|c|c|c|c|}
\hline Level & Number & Mean & Std Error & Lower 95\% & Upper 95\% \\
\hline AQUA REGIA-Product & & 2.66000 & 0.04032 & 2.5721 & 2.7479 \\
\hline AQUA REGIA-Receipt & 3 & 2.45000 & 0.04032 & 2.3621 & 2.5379 \\
\hline COLD CHEM-Product & 3 & 2.62333 & 0.04032 & 2.5355 & 2.7112 \\
\hline COLD CHEM-Receipt & 3 & 2.81000 & 0.04032 & 2.7221 & 2.8979 \\
\hline PEROXIDE FUSION-Product & 3 & 2.51000 & 0.04032 & 2.4221 & 2.5979 \\
\hline PEROXIDE FUSION-Receipt & 3 & 2.59667 & 0.04032 & 2.5088 & 2.6845 \\
\hline
\end{tabular}

Std Error uses a pooled estimate of error variance

\section{Means and Std Deviations}

Level

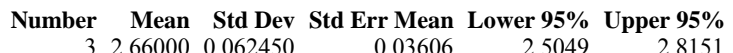

AQUA REGIA-Receipt

$\begin{array}{lrr}0.03606 & 2.5049 & 2.8151 \\ 0.03786 & 2.2871 & 2.6129\end{array}$
Level

COLD CHEM-Product

COLD CHEM-Receipt

PEROXIDE FUSION-Product

Number Mean Std Dev Std Err Mean Lower 95\% Upper 95\% $\begin{array}{llllll}3 & 2.62333 & 0.115036 & 0.06642 & 2.3376 & 2.9091 \\ 3 & 2.81000 & 0.030000 & 0.01732 & 2.7355 & 2.8845\end{array}$

EROXIDE FUSION-Receip

$\begin{array}{ll}2.81000 & 0.030000 \\ 2 & 0\end{array}$

$\begin{array}{lll}0.01732 & 2.7355 & 2.8845 \\ 0.04000 & 2.3379 & 2.6821\end{array}$

Tests that the Variances are Equal

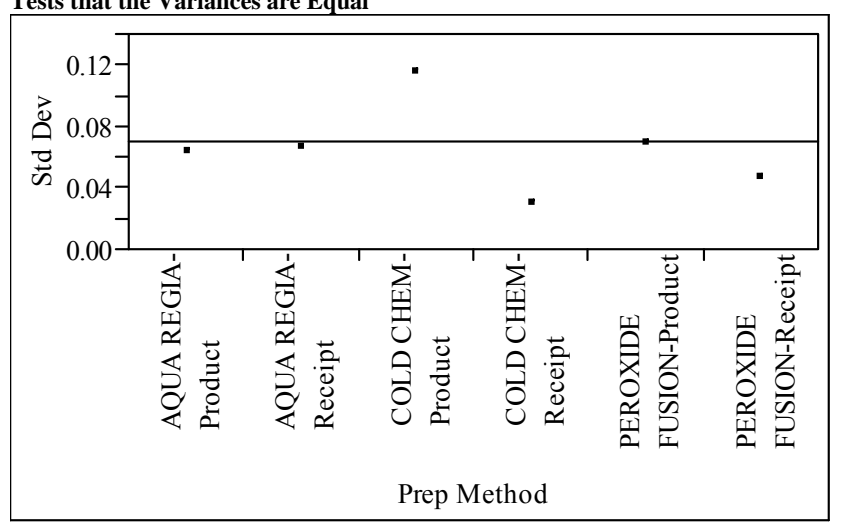

Level

Count Std Dev MeanAbsDif to Mean MeanAbsDif to Median

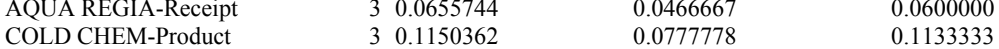

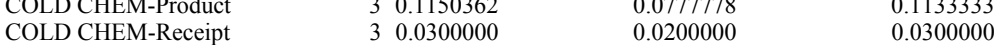

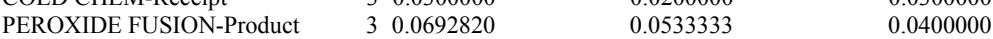

$\begin{array}{llll}\text { PEROXIDE FUSION-Receipt } & 3 & 0.0461880 & 0.0355556\end{array}$

$\begin{array}{lrrrr}\text { Test } & \text { F Ratio } & \text { DFNum } & \text { DFDen } & \text { Prob }>\text { F } \\ \text { O'Brien[.5] } & 0.8495 & 5 & 12 & 0.5408 \\ \text { Brown-Forsythe } & 2.1638 & 5 & 12 & 0.1269 \\ \text { Levene } & 0.9641 & 5 & 12 & 0.4768 \\ \text { Bartlett } & 0.6312 & 5 & . & 0.6759\end{array}$

Warning: Small sample sizes. Use Caution.

Welch Anova testing Means Equal, allowing Std Devs Not Equal

F Ratio DFNum DFDen Prob $>$ F

16.3740

\section{Means Comparisons}

Comparisons for all pairs using Tukey-Kramer HSD

$\begin{array}{lrrr}\text { Level } & & & \text { Mean } \\ \text { COLD CHEM-Receipt } & \text { A } & & 2.8100000 \\ \text { AQUA REGIA-Product } & \text { A } & \text { B } & 2.6600000 \\ \text { COLD CHEM-Product } & \text { A } & \text { B } & \text { C } 2.6233333 \\ \text { PEROXIDE FUSION-Receipt } & \text { B } & \text { C } 2.5966667 \\ \text { PEROXIDE FUSION-Product } & \text { B } & \text { C } 2.5100000 \\ \text { AQUA REGIA-Receipt } & & \text { C } 2.4500000\end{array}$

$\begin{array}{lrl}\text { PEROXIDE FUSION-Product } & \text { B C } 2.5100000 \\ \text { AQUA REGIA-Receipt } & \text { C } 2.4500000\end{array}$ 
Oneway Analysis of Measurement (Wt\%) By Prep Method Sample=ARG, Element $=\mathrm{Ca}$

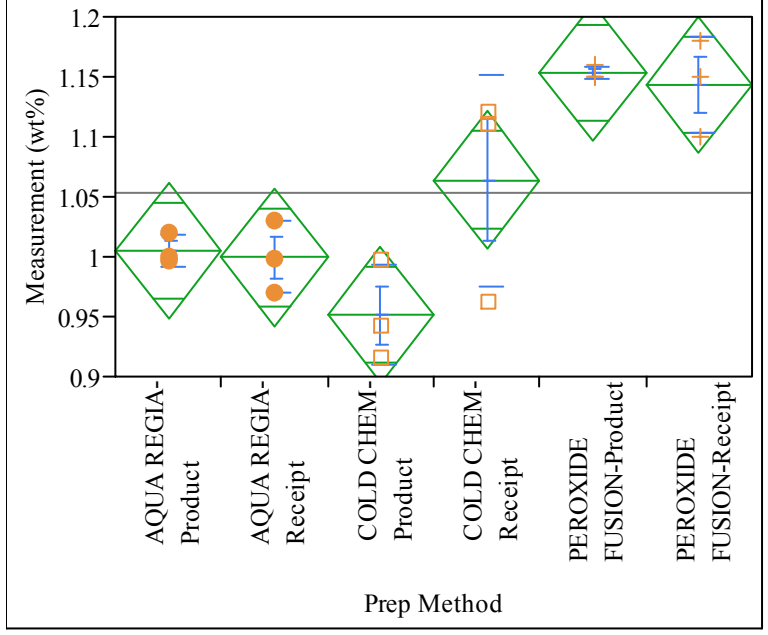

Oneway Anova

Summary of Fit

Adj Rsquare

0.804831

Root Mean Square Error $\quad 0.045291$

Mean of Respons

1.052778

Analysis of Variance

DF Sum of Squares Mean Square F Ratio Prob > F

$\begin{array}{llllll}\text { Prep Method } & 5 & 0.10150778 & 0.020302 & 9.8970 & 0.0006\end{array}$

$\begin{array}{llll}\text { Error } & 12 & 0.02461533 & 0.00205\end{array}$

$\begin{array}{lll}\text { C. Total } & 17 & 0.12612311\end{array}$

Means for Oneway Anova

Number Mean Std Error Lower 95\% Upper 95\%

AQUA REGIA-Product

AQUA REGIA-Receip

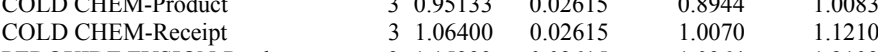

$\begin{array}{lll}3 & 1.00533 & 0.02615 \\ 3 & 0.99933 & 0.02615\end{array}$

$0.9484 \quad 1.0623$

$\begin{array}{llll}0.99933 & 0.02615 & 0.9424 & 1.0563\end{array}$

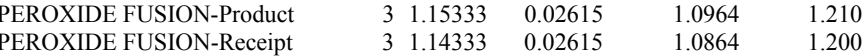

PEROXIDE FUSI

.086

Std Error uses a pooled estimate of error variance

\section{Means and Std Deviations}

Level

AQUA REGIA-Product

AQUA REGIA-Receip

Number Mean Std Dev Std Err Mean Lower 95\% Upper 95\%

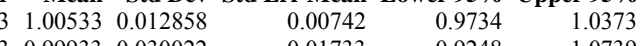

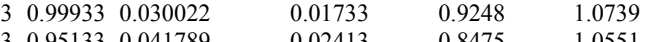
COLD CHEM-Receipt $\begin{array}{lll}0.02413 & 0.8475 & 1.0551 \\ 0.05108 & 0.8442 & 1.2838\end{array}$
Level

Number Mean Std Dev Std Err Mean Lower 95\% Upper 95\%

PEROXIDE FUSION-Product

PEROXIDE FUSION-Receip

$\begin{array}{lll}3 & 1.15333 & 0.005774 \\ 3 & 1.14333 & 0.040415\end{array}$

0.02333

$\begin{array}{ll}.1390 & 1.1677 \\ .0429 & 1.2437\end{array}$

Tests that the Variances are Equal

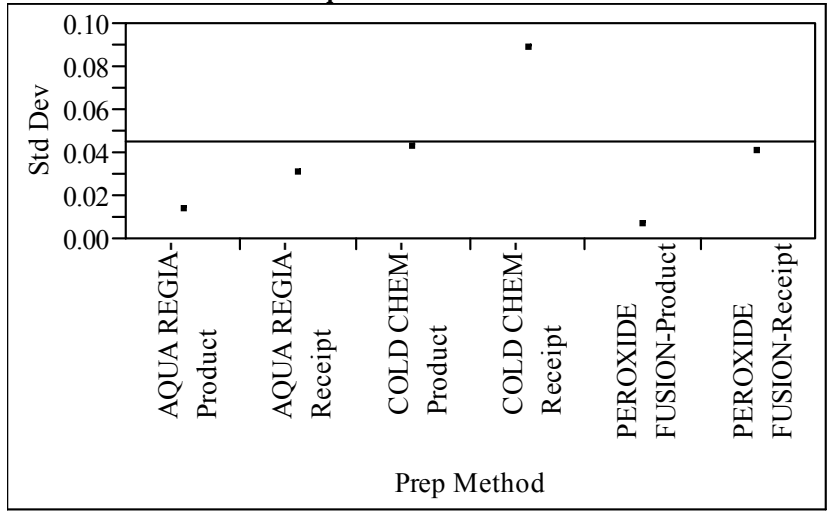

Level

Count Std Dev MeanAbsDif to Mean MeanAbsDif to Median

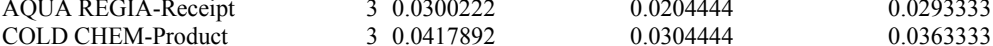

$\begin{array}{llll}\text { COLD CHEM-Receipt } & 30.0884760 & 0.0680000 & 0.0363333 \\ & 3 & 0.057735 & 0.00000\end{array}$

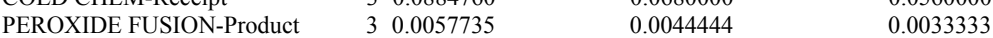

$\begin{array}{lll}\text { PEROXIDE FUSION-Receipt } & 30.0404145 & 0.0288889\end{array}$

Test F Ratio DFNum DFDen Prob $>$ F

$\begin{array}{lllll}\text { O'Brien[.5] } & 1.3394 & 5 & 12 & 0.3128 \\ & 0.9886 & 5 & 12 & 0.4640\end{array}$

$\begin{array}{lllll}\text { Brown-Forsythe } & 0.9886 & 5 & 12 & 0.4640 \\ \text { Levene } & 4.7479 & 5 & 12 & 0.0126\end{array}$

$\begin{array}{lllll}\text { Bartlett } & 2.1800 & 5 & . & 0.0534\end{array}$

Warning: Small sample sizes. Use Caution.

Welch Anova testing Means Equal, allowing Std Devs Not Equal

F Ratio DFNum DFDen Prob > F

57.2140

\section{Means Comparisons}

Comparisons for all pairs using Tukey-Kramer HSD

Level

PEROXIDE FUSION-Product A 1.1533333

PEROXIDE FUSION-Receipt A 1.1433333

COLD CHEM-Receipt A B 1.0640000

$\begin{array}{lll}\text { AQUA REGIA-Product } & \text { B } 1.0053333 \\ \text { AQUA REGIA-Receipt } & \text { B } 0.9993333\end{array}$

COLD CHEM-Product $\quad$ B 0.9513333

Levels not connected by same letter are significantly different. 
Oneway Analysis of Measurement (Wt\%) By Prep Method Sample=ARG, Element $=\mathrm{C}_{r}$

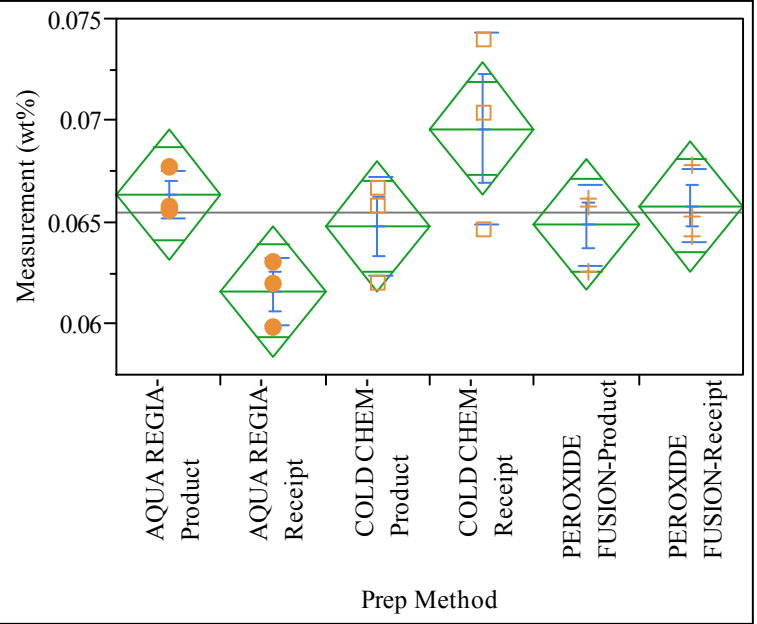

Oneway Anova

Summary of Fit

$\begin{array}{lr}\text { Rsquare } & 0.563632 \\ \text { Adj Rsquare } & 0.381811 \\ \text { Root Mean Square Error } & 0.002556 \\ \text { Mean of Response } & 0.065506 \\ \text { Observations (or Sum Wgts) } & 18\end{array}$

Analysis of Variance

Source DF Sum of Squares Mean Square F Ratio Prob $>$ F

$\begin{array}{lrrrrr}\text { Source } & \text { DF } & \text { Sum of Squares } & \text { Mean Square } & & \\ \text { Prep Methodio } & \text { Prob }>\text { F } \\ \text { Pren } & 5 & 0.00010126 & 0.000020 & 3.0999 & 0.0503\end{array}$

$\begin{array}{lrrr}\text { Prep Method } & 5 & 0.00010126 & 0.000020 \\ \text { Error } & 12 & 0.00007839 & 6.533 \mathrm{e}-6 \\ \text { C. Total } & 17 & 0.00017965 & \end{array}$

Means for Oneway Anova

Level

Number Mean Std Error Lower 95\% Upper 95\%

$\begin{array}{llllll}\text { AQUA REGIA-Product } & 3 & 0.066367 & 0.00148 & 0.06315 & 0.06958 \\ & 3 & 0.0661600 & 0.00148 & 0.05838 & 0.06482\end{array}$

$\begin{array}{llllll} & 3 & 0.066367 & 0.00148 & 0.06315 & 0.06958 \\ \text { AQUA REGIA-Receipt } & 3 & 0.061600 & 0.00148 & 0.05838 & 0.06482 \\ \text { COLD CHEM-Product } & 3 & 0.064800 & 0.00148 & 0.06158 & 0.06802\end{array}$

$\begin{array}{llllll} & 3 & 0.061600 & 0.00148 & 0.05838 & 0.06482 \\ \text { COLD CHEM-Preceipt } & 3 & 0.064800 & 0.00148 & 0.06158 & 0.06802 \\ \text { P } & 3 & 0.069600 & 0.00148 & 0.06638 & 0.07282\end{array}$

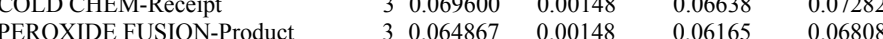

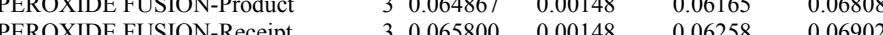

Std Error uses a pooled estimate of error variance

Means and Std Deviations

Level

Level AQUA REGIA-Product

AQUA REGIA-Product

COLD CHEM-Product

COLD CHEM-Receipt
Level

Number Mean Std Dev Std Err Mean Lower 95\% Upper 95\% $\begin{array}{llllll}3 & 0.064867 & 0.001973 & 0.00114 & 0.05997 & 0.06977 \\ 3 & 0.065800 & 0.001803 & 0.00104 & 0.06132 & 0.07028\end{array}$

PEROXIDE FUSION-Product

Tests that the Variances are Equal

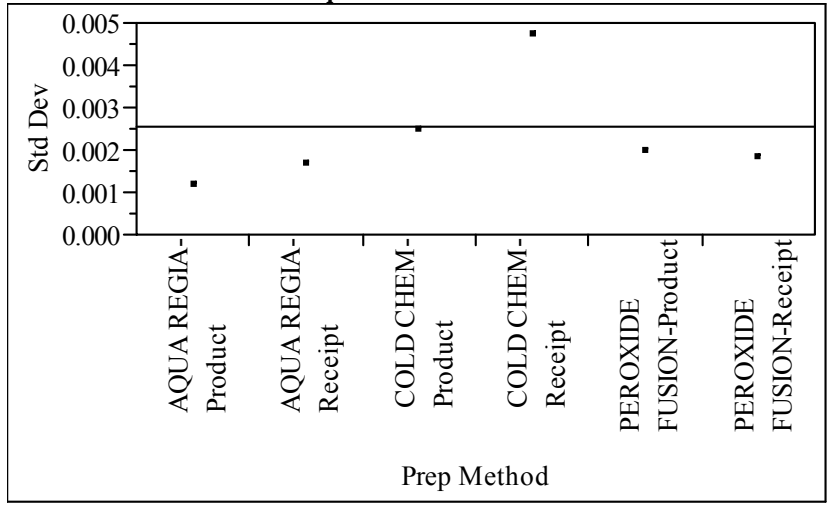

Level

AQUA REGIA-Product

AQUA REGIA-Receipt

$\begin{array}{rrrr}\text { Count } & \text { Std Dev } & \text { MeanAbsDif to Mean } & \text { MeanAbsDif to Median } \\ 3 & 0.0011590 & 0.0008889 & 0.0007667\end{array}$ COLD CHEM-Product PEROXIDE FUSION-Produc

30.0011590
3
0.001631 $\begin{array}{lll}3 & 0.001637 \\ 3 & 0.002576\end{array}$

0.0012000

0.0014000

PEROXIDE FUSION-Receip

30.0024576

0.0018000

$0.0033333 \quad 0.0043000$

.0015000

Test

Ratio DFNum DFDen Prob $>$ F

$\begin{array}{lllll}\text { O'Brien[.5] } & 1.1486 & 5 & 12 & 0.3879\end{array}$

$\begin{array}{lllll}\text { Brown-Forsythe } & 3.0155 & 5 & 12 & 0.0544 \\ \text { Levene } & 1.7266 & 5 & 12 & 0.2030\end{array}$

$\begin{array}{llrrr}\text { Levene } & 1.7266 & 5 & 12 & 0.2030 \\ \text { Bartlett } & 0.8550 & 5 & . & 0.5105\end{array}$

Warning: Small sample sizes. Use Caution.

Welch Anova testing Means Equal, allowing Std Devs Not Equal

$\begin{array}{rrrr}\text { F Ratio } & \text { DFNum } & \text { DFDen } & \text { Prob }>\text { F } \\ 2.7729 & 5 & 5.4947 & 0.1328\end{array}$

Means Comparisons

Comparisons for all pairs using Tukey-Kramer HSD

Level Mean

COLD CHEM-Receipt A 0.06960000

AQUA REGIA-Product A B 0.06636667

PEROXIDE FUSION-Receipt A B 0.06580000

PEROXIDE FUSION-Product A B 0.06486667

COLD CHEM-Product A B 0.06480000

AQUA REGIA-Receipt $\quad$ B 0.06160000

Levels not connected by same letter are significantly different. 
Oneway Analysis of Measurement (Wt\%) By Prep Method Sample=ARG, Element $=\mathrm{Cu}$

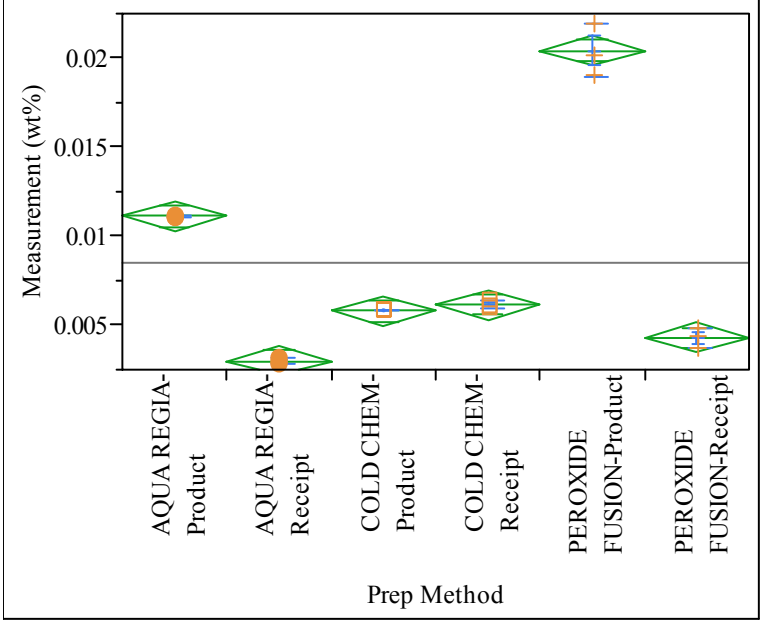

Oneway Anova

Summary of Fit

$\begin{array}{lr}\text { Rsquare } & 0.992021 \\ \text { Adj Rsquare } & 0.988696 \\ \text { Root Mean Square Error } & 0.00065 \\ \text { Mean of Response } & 0.008469 \\ \text { Observations (or Sum Wgts) } & 18\end{array}$

Observations (or Sum Wgts) 0.008469

Analysis of Variance

Source DF Sum of Squares Mean Square F Ratio Prob $>$ F

$\begin{array}{lrrrrr}\text { Prep Method } & 5 & 0.00063004 & 0.000126 & 298.3867 & <.0001\end{array}$

$\begin{array}{lrrr}\text { Error } & 12 & 0.00000507 & 4.223 \mathrm{e}-7 \\ \text { C. Total } & 17 & 0.00063511 & \end{array}$

Means for Oneway Anova

Level

Number Mean Std Error Lower 95\% Upper 95\%

AQUA REGIA-Product

AQUA REGIA-Receipt

COLD CHEM-Product

COLD CHEM-Receip

PEROXIDE FUSION-Product

$\begin{array}{lll}3 & 0.011133 & 0.00038 \\ 3 & 0.003000 & 0.00038\end{array}$

$0.01032-0.01195$

N-Product

$\begin{array}{lllll}3 & 0.005800 & 0.00038 & 0.00498 & 0.00662\end{array}$

$\begin{array}{lllll}3 & 0.005800 & 0.0038 & 0.00488 & 0.00662 \\ 3 & 0.006137 & 0.00038 & 0.00532 & 0.00695\end{array}$

PEROXIDE FUSION-Receipt

$\begin{array}{llll}0.020433 & 0.00038 & 0.01962 & 0.02125 \\ 0.004310 & 0.00038 & 0.00349 & 0.00513\end{array}$

Std Error uses a pooled estimate of error variance

Means and Std Deviations

Level

Number Mean Std Dev Std Err Mean Lower 95\% Upper 95\%

AQUA REGIA-Product

AQUA REGIA-Receipt

COLD CHEM-Product

COLD CHEM-Receipt $\begin{array}{llllll}3 & 0.011133 & 0.000058 & 3.33 \mathrm{e}-5 & 0.01099 & 0.01128 \\ 3 & 0.003000 & 0.000130 & 7.51 \mathrm{e}-5 & 0.00268 & 0.00332\end{array}$

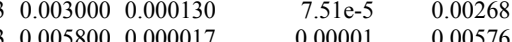

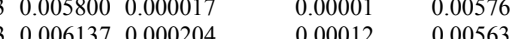

Level

Number Mean Std Dev Std Err Mean Lower 95\% Upper 95\% $\begin{array}{lllllll}\text { PEROXIDE FUSION-Product } & 3 & 0.020433 & 0.001464 & 0.00085 & 0.01680 & 0.02407 \\ \text { PEROXIDE FUSION-Receipt } & 3 & 0.004310 & 0.000573 & 0.00033 & 0.00289 & 0.00573\end{array}$

Tests that the Variances are Equal

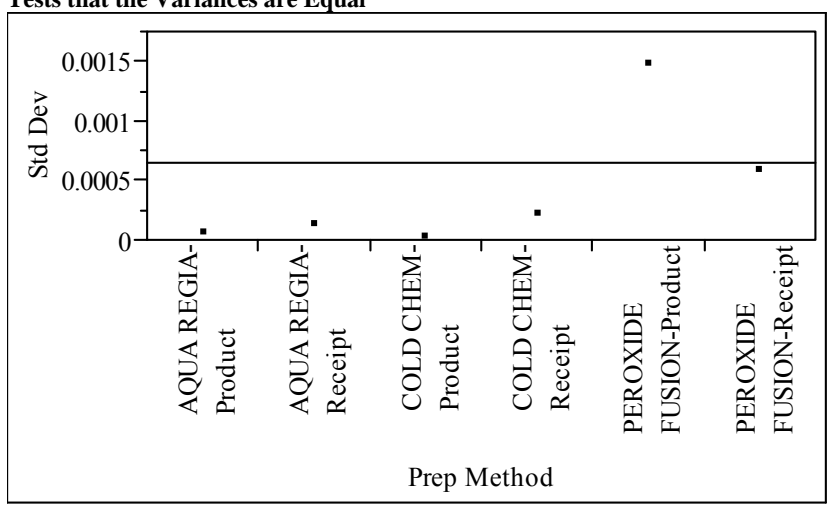

Lev

LEVA REGIA-PIOdT Count

if to Mean MeanAbsDif to Median

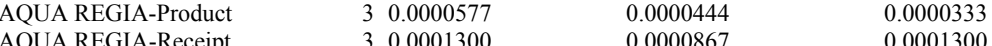

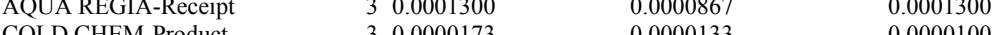

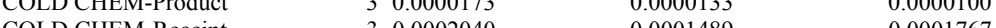

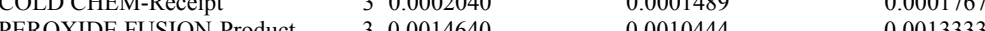
PEROXIDE FUSION-Receipt $\quad 30.00005730-0.0010444-0.0013333$

\section{Test F Ratio DFNum DFDen Prob $>$ F}

$\begin{array}{lrrrr}\text { O'Brien[.5] } & 1.6480 & 5 & 12 & 0.2214\end{array}$

$\begin{array}{lrrrr}\text { Brown-Forsythe } & 22.0567 & 5 & 12 & <.0001 \\ \text { Levene } & 4.7464 & 5 & 12 & 0.0127\end{array}$

$\begin{array}{lllll}\text { Levene } & 4.7464 & 5 & 12 & 0.0127 \\ \text { Bartlett } & 5.4432 & 5 & . & <.0001\end{array}$

Warning: Small sample sizes. Use Caution.

Welch Anova testing Means Equal, allowing Std Devs Not Equal

F Ratio DFNum DFDen Prob $>$ F

$\begin{array}{llllll}3308.6476 & 5 & 4.8513 & <.0001\end{array}$

Means Comparisons

Comparisons for all pairs using Tukey-Kramer HSD

Level

PEROXIDE FUSION-Product A Mean AQUA REGIA-Product B B $\quad 0.02043333$ $\begin{array}{llll}\text { COLD CHEM-Receipt } & \text { B } & 0.0113333 \\ \text { COD } & & 0.00613667\end{array}$ PEROXIDE FUSION-Receipt C D 0.00580000 PEROXIDE FUSION-Receipt D E 0.00431000 AQUA REGIA-Receip

Levels not connected by same letter are significantly different. 
Oneway Analysis of Measurement (Wt\%) By Prep Method Sample=ARG, Element=Fe

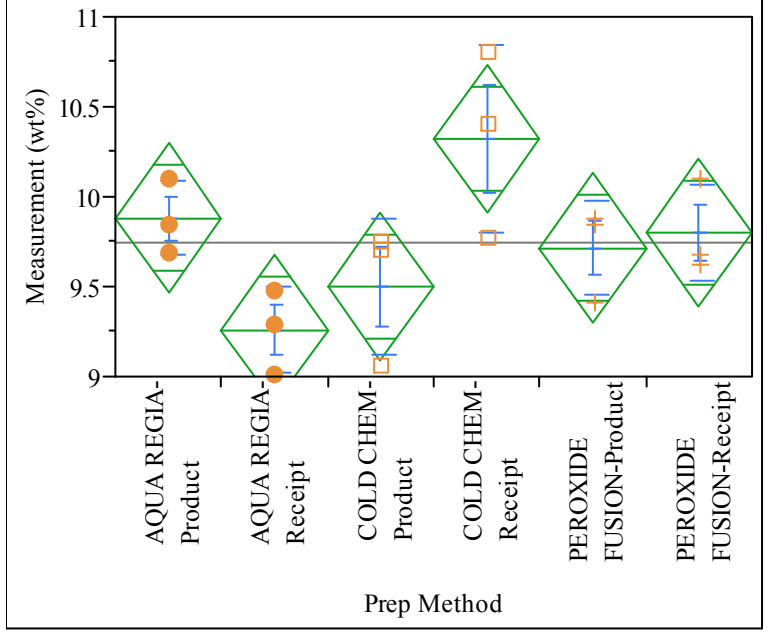

Oneway Anova

Summary of Fit

Adj Rsquare

0.600183

Root Mean Square Error $\quad 0.329511$

Mean of Respons

9.746111

Observations (or Sum Wgts)

Analysis of Variance

Dource Sum of Squares Mean Square F Ratio Prob $>$ F

$\begin{array}{lrrrrr}\text { Prep Method } & 5 & 1.9558944 & 0.391179 & 3.6028 & 0.0320\end{array}$

$\begin{array}{lll}\text { Error } & 12 & 1.3029333\end{array}$

0.108578

Means for Oneway Anova

Level

$\begin{array}{rrrrr}\text { Number } & \text { Mean } & \text { Std Error } & \text { Lower 95\% } & \text { Upper 95\% } \\ 3 & 9.8800 & 0.19024 & 9.4655 & 10.295 \\ 3 & 9.2600 & 0.19024 & 8.8455 & 9.65\end{array}$

Leve

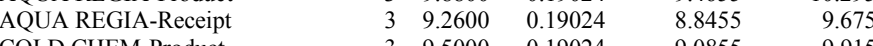
$\begin{array}{llllll}\text { COLD CHEM-Product } & 3 & 9.5000 & 0.19024 & 9.0855 & 9.915\end{array}$

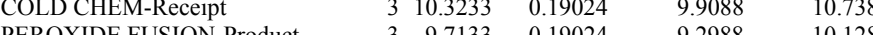
$\begin{array}{llllll}\text { PEROXIDE FUSION-Product } & 3 & 9.7133 & 0.19024 & 9.2988 & 10.128 \\ \text { PEROXIDE FUSION-Receipt } & 3 & 9.8000 & 0.19024 & 9.3855 & 10.215\end{array}$

Std Error uses a pooled estimate of error variance

\section{Means and Std Deviations}

Level

AQUA REGIA-Product

AQUA REGIA-Receip

COLD CHEM-Receipt

Number Mean Std Dev Std Err Mean Lower 95\% Upper 95\% $\begin{array}{lll}3.8800 & 0.206640\end{array}$ 0.11930

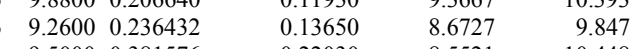

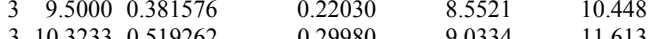

Level

Number Mean Std Dev Std Err Mean Lower 95\% Upper 95\%

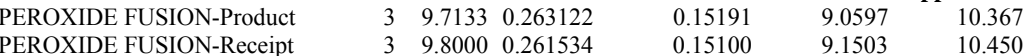

Tests that the Variances are Equal

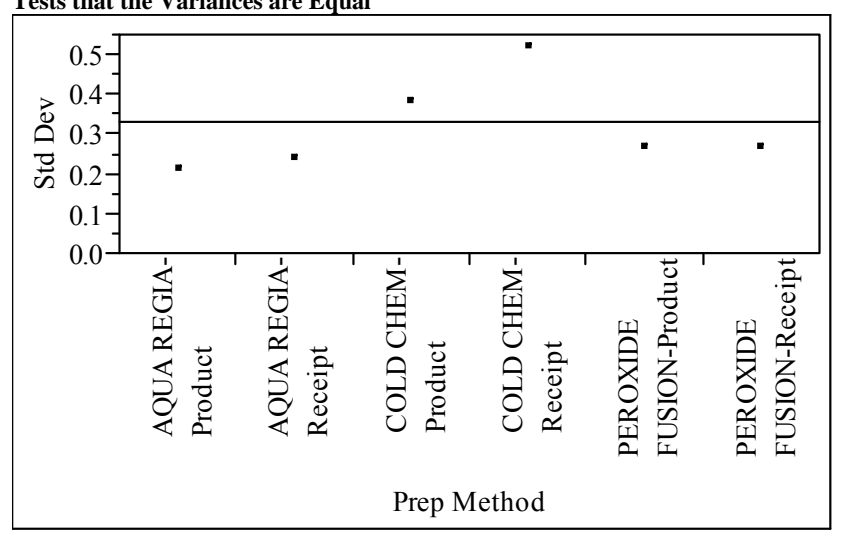

Level

AQUA REGIA-Product

AQUA REGIA-Receipt

COLD CHEM-Receip

PEROXIDE FUSION-Product Count Std Dev MeanAbsDif to Mean MeanAbsDif to Median 0.1466667

0.2200000

$\begin{array}{rrrrr}3 & 0.5192623 & 0.3688889 & 0.4766667 \\ & 3 & 0.2631223 & 0.2022222 & 0.1666667\end{array}$

$\begin{array}{lrrrr}\text { Test } & \text { F Ratio } & \text { DFNum } & \text { DFDen } & \text { Prob }>\text { F } \\ \text { O'Brien[.5] } & 0.7402 & 5 & 12 & 0.6079 \\ \text { Brown-Forsythe } & 1.0061 & 5 & 12 & 0.4551 \\ \text { Levene } & 1.0515 & 5 & 12 & 0.4326 \\ \text { Bartlett } & 0.4374 & 5 & . & 0.8227\end{array}$

Warning: Small sample sizes. Use Caution.

Welch Anova testing Means Equal, allowing Std Devs Not Equal

$\begin{array}{rrrr}\text { F Ratio } & \text { DFNum } & \text { DFDen } & \text { Prob }>\text { F } \\ 2.4607 & 5 & 5.5472 & 0.1605\end{array}$

Means Comparisons

Comparisons for all pairs using Tukey-Kramer HSD

Level

COLD CHEM-Receipt A $\begin{array}{rr}\text { Mean } \\ \text { A } 10.323333\end{array}$

AQUA REGIA-Product A B 9.880000

PEROXIDE FUSION-Product A B 9.713333

COLD CHEM-Product

$\begin{array}{lrr}\text { AQUA REGIA-Receipt } & \text { A B } & 9.500000 \\ & \text { B } & 9.260000\end{array}$

Levels not connected by same letter are significantly different. 
Oneway Analysis of Measurement (Wt\%) By Prep Method Sample=ARG, Element=K

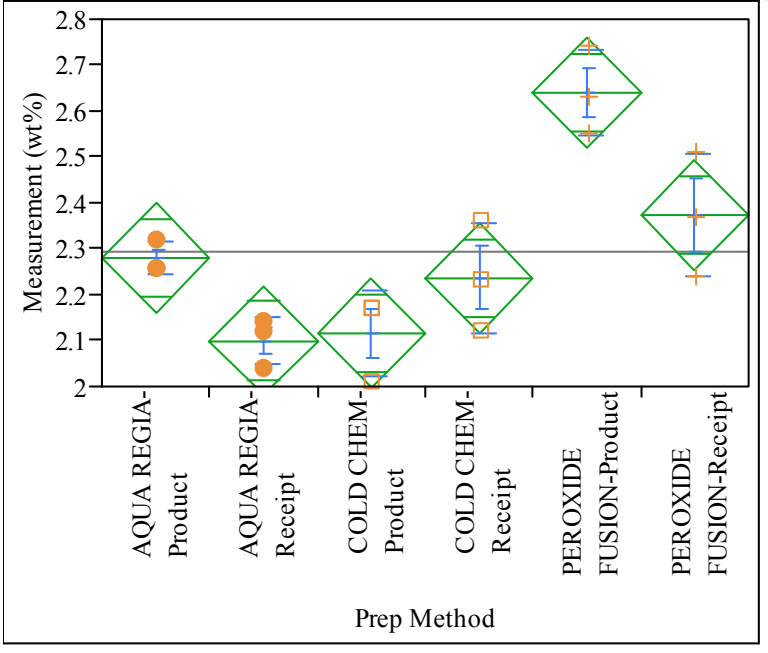

\section{Oneway Anova}

Summary of Fit

$\begin{array}{lr}\text { Rsquare } & 0.845778 \\ \text { Adj Rsquare } & 0.781518 \\ \text { Root Mean Square Error } & 0.095131 \\ \text { Mean of Response } & 2.291111 \\ \text { Observations (or Sum Wgts) } & 18\end{array}$

\section{Analysis of Variance}

Source DF Sum of Squares Mean Square F Ratio Prob $>$ F

$\begin{array}{lrrrrr}\text { Prep Method } & 5 & 0.59557778 & 0.119116 & 13.1619 & 0.0002\end{array}$

$\begin{array}{lrrr}\text { Prep } & 12 & 0.10860000 & 0.009050 \\ \text { C. Total } & 17 & 0.70417778 & \end{array}$

\section{Means for Oneway Anova}

Level

AQUA REGIA-Product

Number Mean Std Error Lower 95\% Upper 95\%

AQUA REGIA-Receipt

COLD CHEM-Product

COLD CHEM-Receipt

$\begin{array}{ll}2.28000 & 0.05492\end{array}$

2.1603 Upper 95\%

$\begin{array}{lll}3 & 2.10000 & 0.05492\end{array}$

$\begin{array}{ll}1.9803 & 2.2197 \\ 1.9970 & 2.2363\end{array}$

$\begin{array}{llllll} & 3 & 2.2367 & 0.0542 & 1.9970 & 2.2363 \\ & 3 & 2.23667 & 0.05492 & 2.1170 & 2.3563\end{array}$

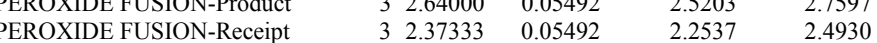

Std Error uses a pooled estimate of error variance

\section{Means and Std Deviations}

Level

AQUA REGIA-Receip

COLD CHEM-Product

Number Mean Std Dev Std Err Mean Lower 95\% Upper 95\%

$\begin{array}{llllll}3 & 2.28000 & 0.034641 & 0.02000 & 2.1939 & 2.3661\end{array}$

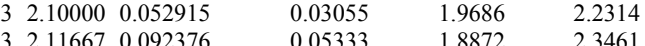

COLD CHEM-Receipt
Level

Number Mean Std Dev Std Err Mean Lower 95\% Upper 95\%

PEROXIDE FUSION-Product

PEROXIDE FUSION-Receip

$\begin{array}{lll}3 & 2.37333 & 0.135031\end{array}$

0.07796

$\begin{array}{ll}.40379 & 2.877088\end{array}$

Tests that the Variances are Equal

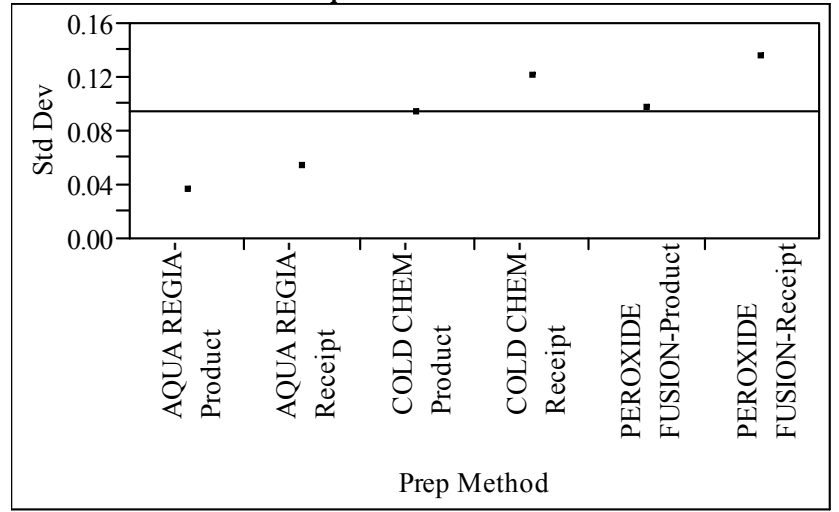

Level

Count Std Dev MeanAbsDif to Mean MeanAbsDif to Median

AQUA REGIA-R

30.0346410

0.0266667

0.0200000

COLD CHEM-Produc

$\begin{array}{ll}3 & 0.0529150 \\ 3 & 0.0923760\end{array}$

0.0711111

$\begin{array}{lll}3 & 0.0923760 \\ 3 & 0.1201388\end{array}$

PEROXIDE FUSION-Product

$\begin{array}{ll}3 & 0.1201388 \\ 3 & 0.0953939 \\ 3 & 0.1350309\end{array}$

0.0822222

0.0400000

PEROXIDE FUSIONToduct

0.0900000

Test $\quad$ F Ratio DFNum DFDen Prob $>$ F

$\begin{array}{lllll}\text { O'Brien[.5] } & 0.6477 & 5 & 12 & 0.6687 \\ \text { Brown-Forsythe } & 3.1836 & 5 & 12 & 0.0465\end{array}$

$\begin{array}{lllll}\text { Brown-Forsythe } & 3.1836 & 5 & 12 & 0.0465 \\ \text { Levene } & 0.7947 & 5 & 12 & 0.5738 \\ \text { Ban } & 0.6964 & 5 & & 0.6261\end{array}$

$\begin{array}{lllll}\text { Bartlett } & 0.6964 & 5 & . & 0.6261\end{array}$

Warning: Small sample sizes. Use Caution.

Welch Anova testing Means Equal, allowing Std Devs Not Equal

F Ratio DFNum DFDen Prob > F

11.3797

\section{Means Comparisons}

Comparisons for all pairs using Tukey-Kramer HSD

$\begin{array}{lr}\text { Level } & \text { Mean } \\ \text { PEROXIDE FUSION-Product A } & 2.6400000\end{array}$

PEROXIDE FUSION-Receipt $\quad$ B 2.3733333

AQUA REGIA-Product $\quad$ B C 2.2800000

COLD CHEM-Receipt $\quad$ B C 2.2366667

COLD CHEM-Product $\quad$ B C 2.1166667

AQUA REGIA-Receipt $\quad$ C 2.1000000

Levels not connected by same letter are significantly different. 
Oneway Analysis of Measurement (Wt\%) By Prep Method Sample=ARG, Element=Li

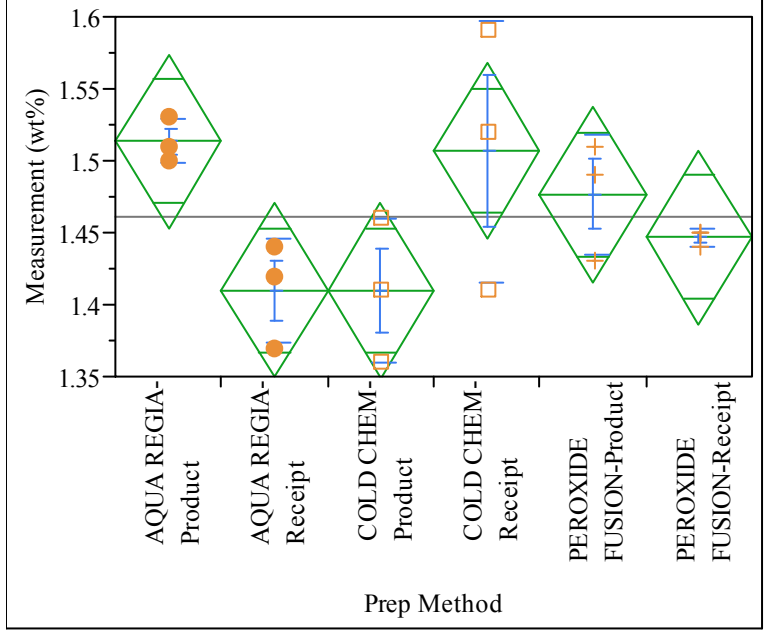

Oneway Anova

Summary of Fit

$\begin{array}{lr}\text { Rsquare } & 0.528247 \\ \text { Adj Rsquare } & 0.331684 \\ \text { Root Mean Square Error } & 0.048362 \\ \text { Mean of Response } & 1.460556 \\ \text { Observations (or Sum Wgts) } & 18\end{array}$

Analysis of Variance

DF Sum of Squares Mean Square F Ratio Prob > F

$\begin{array}{llllll}\text { Prep Method } & 5 & 0.03142778 & 0.006286 & 2.6874 & 0.0746\end{array}$

$\begin{array}{llll}\text { Error } & 12 & 0.02806667 & 0.002339\end{array}$

Means for Oneway Anova

Number Mean Std Error Lower 95\% Upper 95\% $\begin{array}{lrrrrr}\text { AQUA REGIA-Product } & 3 & 1.51333 & 0.02792 & 1.4525 & 1.5742 \\ \text { AQUA REGIA-Receipt } & 3 & 1.41000 & 0.02792 & 1.3492 & 1.4708 \\ \text { COLD CHEM-Product } & 3 & 1.41000 & 0.02792 & 1.3492 & 1.4708\end{array}$ $\begin{array}{llllll}\text { COLD CHEM-Product } & 3 & 1.41000 & 0.02792 & 1.3492 & 1.4708 \\ \text { COLD CHEM-Receipt } & 3 & 1.50667 & 0.02792 & 1.4458 & 1.5675\end{array}$ $\begin{array}{llllll}\text { COLD CHEM-Receipt } & 3 & 1.50667 & 0.02792 & 1.4458 & 1.5675 \\ \text { PEROXIDE FUSION-Product } & 3 & 1.47667 & 0.02792 & 1.4158 & 1.5375\end{array}$ $\begin{array}{llllll}\text { PEROXIDE FUSION-Product } & 3 & 1.47667 & 0.02792 & 1.4158 & 1.5375 \\ \text { PEROXIDE FUSION-Receipt } & 3 & 1.44667 & 0.02792 & 1.3858 & 1.5075\end{array}$

Std Error uses a pooled estimate of error variance

\section{Means and Std Deviations}

Level

AQUA REGIA-Product

COUA REGIA-Receipt

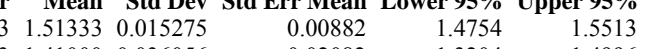

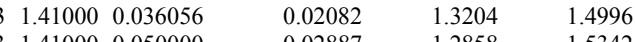
$\begin{array}{llllll}3 & 1.41000 & 0.050000 & 0.02887 & 1.2858 & 1.5342 \\ 3 & 1.50667 & 0.090738 & 0.05239 & 1.2813 & 1.7321\end{array}$
Level

Number Mean Std Dev Std Err Mean Lower 95\% Upper 95\%

PEROXIDE FUSION-Product

PEROXIDE FUSION-Receip

$\begin{array}{lll}3 & 1.47667 & 0.041633 \\ 3 & 1.44667 & 0.005774\end{array}$

0.00333

$1.37323-1.5801$

Tests that the Variances are Equal

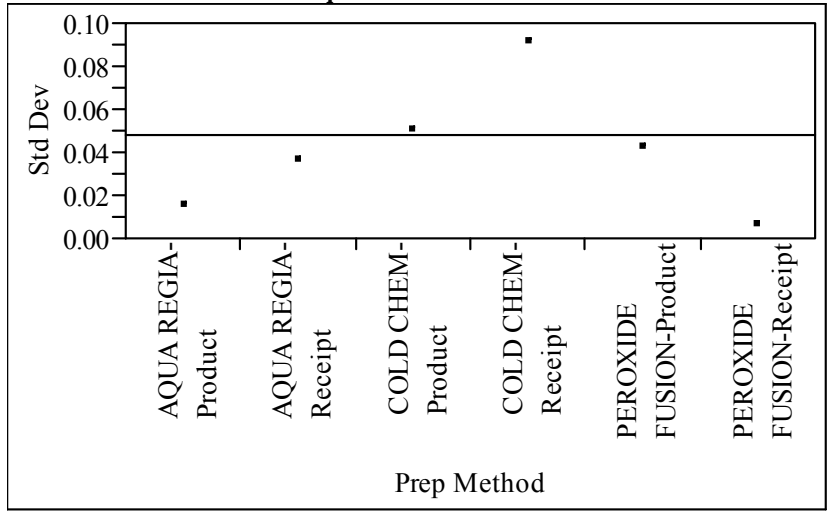

Level

Count Std Dev MeanAbsDif to Mean MeanAbsDif to Median

AQUA REGIA-

COLD CHEM-Product

0.0111111

$\begin{array}{lll}3 & 0.0360555 \\ 3 & 0.0500000\end{array}$

0.0266667

0.0133333

COLD CHEM-Receipt

$\begin{array}{ll}3 & 0.05000000 \\ 3 & 0.09737\end{array}$

0.0333333

0.0500000

PEROXIDE FUSION-Product

$\begin{array}{ll}3 & 0.0907377 \\ 3 & 0.0416333 \\ 3 & 0.0057735\end{array}$

0.0311111

0.0833333

PEROXIDE FUSION-Receipt

30.0057735

0.0044444

Test F Ratio DFNum DFDen Prob $>$ F

$\begin{array}{lrrrr}\text { O'Brien[.5] } & 1.2446 & 5 & 12 & 0.3481 \\ & 10.1953 & 5 & 12 & 0.0005\end{array}$

$\begin{array}{lrrrr}\text { Brown-Forsythe } & 10.1953 & 5 & 12 & 0.0005 \\ \text { Levene } & 2.3338 & 5 & 12 & 0.1064 \\ \text { Bare } & 2.0487 & 5 & & 0.0686\end{array}$

$\begin{array}{lllll}\text { Bartlett } & 2.0487 & 5 & . & 0.10686\end{array}$

Warning: Small sample sizes. Use Caution.

Welch Anova testing Means Equal, allowing Std Devs Not Equal

F Ratio DFNum DFDen Prob > F

Means Comparison

Comparisons for all pairs using Tukey-Kramer HSD

$\begin{array}{lr}\text { Level } & \begin{array}{r}\text { Mean } \\ \text { AQUA REGIA-Product }\end{array} \text { A } 1.5133333\end{array}$

COLD CHEM-Receipt A 1.5066667

PEROXIDE FUSION-Product A 1.4766667

PEROXIDE FUSION-Receipt A 1.4466667

AQUA REGIA-Receipt A 1.4100000

Levels not connected by same letter are significantly different. 
Oneway Analysis of Measurement (Wt\%) By Prep Method Sample=ARG, Element=Mg

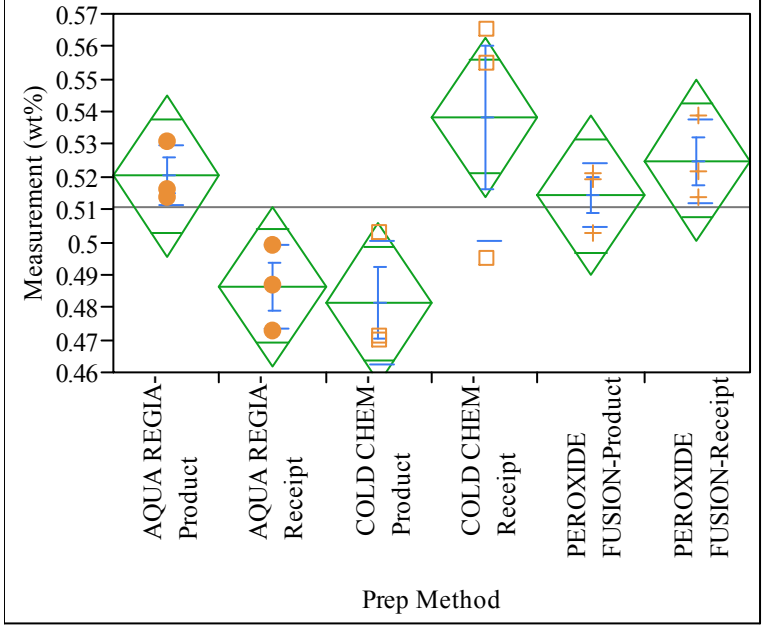

Oneway Anova

Summary of Fit

$\begin{array}{lr}\text { Rsquare } & 0.622459 \\ \text { Adj Rsquare } & 0.465151 \\ \text { Root Mean Square Error } & 0.019586 \\ \text { Mean of Response } & 0.510944 \\ \text { Observations (or Sum Wgts) } & 18\end{array}$

Analysis of Variance

DF Sum of Squares Mean Square F Ratio Prob $>$ F

$\begin{array}{lrllll}\text { Prep Method } & 5 & 0.00758961 & 0.001518 & 3.9569 & 0.0237\end{array}$

$\begin{array}{llll}\text { Error } & 12 & 0.00460333 & 0.000384 \\ \text { C. Total } & 17 & 0.01219294 & \end{array}$

Means for Oneway Anova

Number Mean Std Error Lower 95\% Upper 95\% $\begin{array}{rrrr}0.520333 & 0.01131 & 0.49570 & 0.54497\end{array}$ $\begin{array}{llllll}\text { AQUA REGIA-Receipt } & 3 & 0.486333 & 0.01131 & 0.46170 & 0.51097 \\ \text { COLD CHEM-Product } & 3 & 0.481333 & 0.01131 & 0.45670 & 0.50597\end{array}$ $\begin{array}{llllll}\text { COLD CHEM-Product } & 3 & .481333 & 0.0131 & 0.45670 & 0.51097 \\ \text { COLD CHEM-Receipt } & 3 & 0.538333 & 0.01131 & 0.51370 & 0.56297\end{array}$ $\begin{array}{llllll}\text { COLD CHEM-Receipt } & 3 & 0.514333 & 0.01131 & 0.48970 & 0.53897\end{array}$ $\begin{array}{llllll}\text { PEROXIDE FUSION-Receipt } & 3 & 0.525000 & 0.01131 & 0.50036 & 0.54964\end{array}$

Std Error uses a pooled estimate of error variance

\section{Means and Std Deviations}

Level

AQUA REGIA-Product

COUA REGIA-Receipt

Number Mean Std Dev Std Err Mean Lower 95\% Upper 95\% $\begin{array}{llllll}3 & 0.520333 & 0.009292 & 0.00536 & 0.49725 & 0.54341\end{array}$ $\begin{array}{llllll}3 & 0.486333 & 0.013013 & 0.00751 & 0.45401 & 0.51866 \\ 3 & 0.481333 & 0.018771 & 0.01084 & 0.43470 & 0.52796\end{array}$ $\begin{array}{llllll}3 & 0.481333 & 0.018771 & 0.01084 & 0.43470 & 0.52796 \\ 3 & 0.538333 & 0.037859 & 0.02186 & 0.44429 & 0.63238\end{array}$
Level

Number Mean Std Dev Std Err Mean Lower 95\% Upper 95\%

$\begin{array}{rrrrrr}3 & 0.514333 & 0.009866 & 0.00570 & 0.48983 & 0.53884 \\ 3 & 0.525000 & 0.012767 & 0.00737 & 0.49328 & 0.55672\end{array}$

PEROXIDE FUSION-Receipt

0.55672

Tests that the Variances are Equal

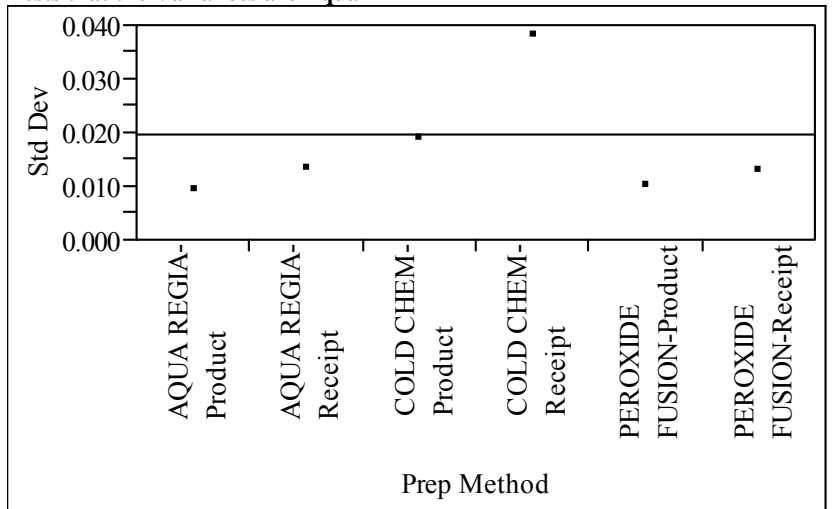

Level

AQUA REGIA-Product

AQUA REGIA-Receipt

Count Std Dev MeanAbsDif to Mean MeanAbsDif to Median

COLD CHEM-Receipt

$\begin{array}{lll}3 & 0.0092916 \\ 3 & 0.0130128 \\ 3 & 0.0187705\end{array}$

$\begin{array}{lll}3 & 0.0130128 \\ 3 & 0.0187705\end{array}$

$\begin{array}{ll}3 & 0.0378594 \\ 3 & 0.098658\end{array}$

0.0071111

0.0088889

0.0063333

PEROXIDE FUSION-Product

$\begin{array}{ll}3 & 0.0098658 \\ 3 & 0.0127671\end{array}$

0.0288889

0.0113333

PEROXIDE FUSION-Receip

0.0093333

0.0066667

0.0110000

Test F Ratio DFNum DFDen Prob $>$ F

$\begin{array}{lllll}\text { O'Brien[.5] } & 1.2965 & 5 & 12 & 0.3283 \\ \text { Brown-Forsythe } & 0.7632 & 5 & 12 & 0.5934\end{array}$

$\begin{array}{lllll}\text { Brown-Forsythe } & 0.7632 & 5 & 12 & 0.5934 \\ \text { Levene } & 3.8483 & 5 & 12 & 0.0259\end{array}$

$\begin{array}{lllll}\text { Levene } & 3.8483 & 5 & 12 & 0.0359 \\ \text { Bartlett } & 1.1063 & 5 & . & 0.3545\end{array}$

Warning: Small sample sizes. Use Caution.

Welch Anova testing Means Equal, allowing Std Devs Not Equal

\section{F Ratio DFNum DFDen Prob $>$ F}

\section{Means Comparisons}

Comparisons for all pairs using Tukey-Kramer HSD

Level

COLD CHEM-Receipt A 0.53833333

$\begin{array}{llll}\text { PEROXIDE FUSION-Receipt A B } & 0.5250033 \\ \text { AQUA REGIA-Product } & \text { A } & \text { B } 0.5203333\end{array}$

PEROXIDE FUSION-Product A B 0.51433333

AQUA REGIA-Receipt A B 0.48633333

COLD CHEM-Product $\quad$ B 0.48133333

Levels not connected by same letter are significantly different. 
Oneway Analysis of Measurement (Wt\%) By Prep Method Sample=ARG, Element=Mn

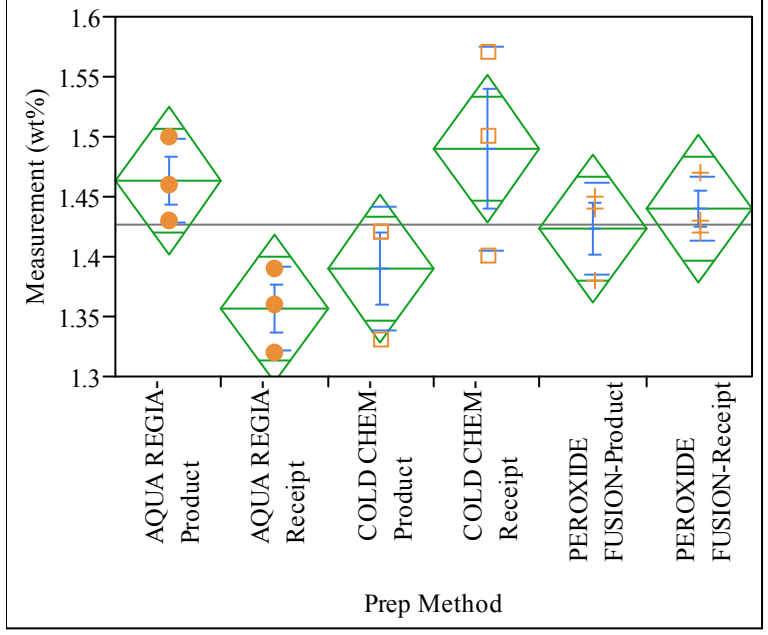

Oneway Anova

Summary of Fit

Rsquare

0.547715

Adj Rsquare

0.359263

Root Mean Square Error $\quad 0.049329$

Mean of Respons

1.427222

Analysis of Variance

DF Sum of Squares Mean Square F Ratio Prob > F

$\begin{array}{lrrrrr}\text { Prep Method } 5 & 0.03536111 & 0.007072 & 2.9064 & 0.0603\end{array}$

$\begin{array}{llll}\text { Error } & 12 & 0.02920000 & 0.00243\end{array}$

$\begin{array}{lll}\text { C. Total } & 17 & 0.0645611\end{array}$

Means for Oneway Anova

Level

Number Mean Std Error Lower 95\% Upper 95\%

$\begin{array}{llllll}\text { AQUA REGIA-Product } & 3 & 1.46333 & 0.02848 & 1.4013 & 1.5254\end{array}$

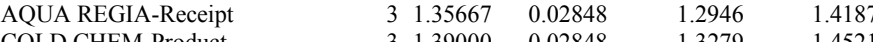

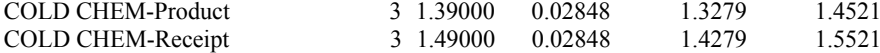

$\begin{array}{llllll}\text { COLD CHEM-Receipt } & 3 & 1.49000 & 0.02848 & 1.4279 & 1.5521 \\ \text { PEROXIDE FUSION-Product } & 3 & 1.42333 & 0.02848 & 1.3613 & 1.4854 \\ & & 1.4900 & 0.02848 & 1.3779 & 1.5021\end{array}$

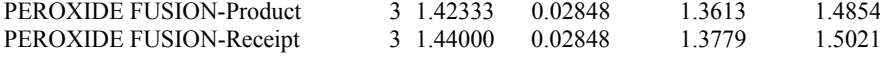

Std Error uses a pooled estimate of error variance

\section{Means and Std Deviations}

Level

AQUA REGIA-Product

AQUA REGIA-Receipt

Number Mean Std Dev Std Err Mean Lower 95\% Upper 95\%

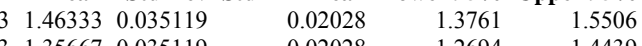

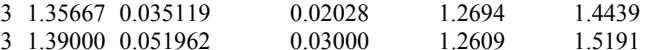

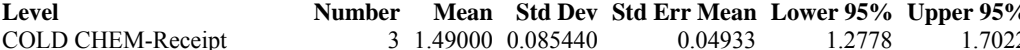

$\begin{array}{lllllll}\text { PEROXIDE FUSION-Product } & 3 & 1.49333 & 0.037859 & 0.02186 & 1.3293 & 1.5174\end{array}$

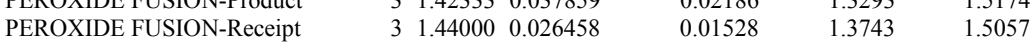

Tests that the Variances are Equal

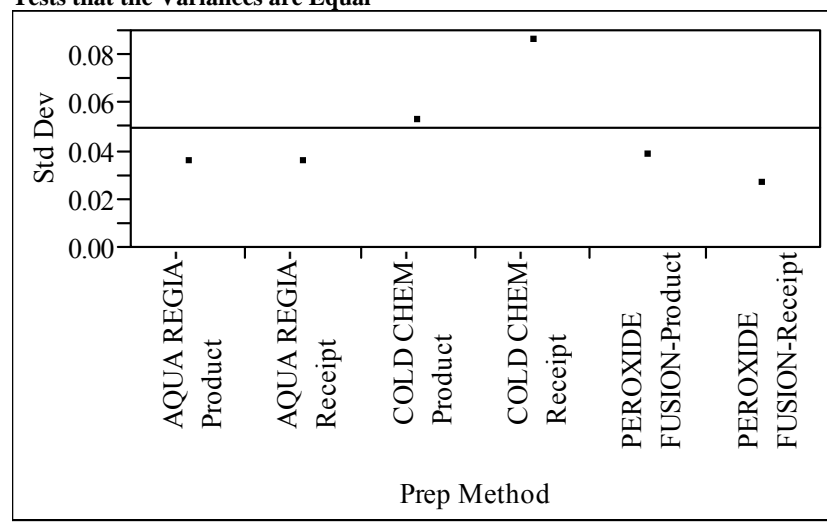

Level

AQUA REGIA-Product

AQUA REGIA-Receipt

COLD CHEM-Roduct

PEROXIDE FUSION-Prod

PEROXIDE FUSION-Recei

Count Std Dev MeanAbsDif to Mean MeanAbsDif to Median

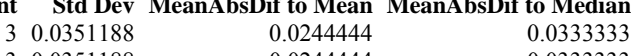

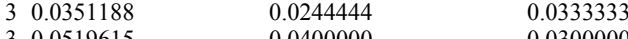

$30.0854400-0.060000-0.0300000$

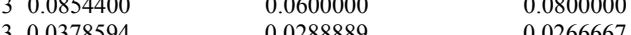

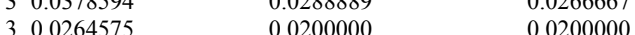

Test F Ratio DFNum DFDen Prob $>$ F

$\begin{array}{lrrrr}\text { O'Brien[.5] } & 0.9879 & 5 & 12 & 0.4644\end{array}$

$\begin{array}{lllll}\text { Brown-Forsythe } & 1.9889 & 5 & 12 & 0.1527 \\ \text { Levene } & 1.2667 & 5 & 12 & 0.3395\end{array}$

$\begin{array}{lllll}\text { Levene } & 1.2667 & 5 & 12 & 0.3395 \\ \text { Bartlett } & 0.6469 & 5 & . & 0.6639\end{array}$

Warning: Small sample sizes. Use Caution.

Welch Anova testing Means Equal, allowing Std Devs Not Equal

$\begin{array}{rrrrr}\text { F Ratio } & \text { DFNum } & \text { DFDen } & \text { Prob }>\text { F } \\ 2.5572 & 5 & 5.5282 & 0.1512\end{array}$

\section{Means Comparisons}

Comparisons for all pairs using Tukey-Kramer HSD
$\begin{array}{lr}\text { Level } & \text { Mean } \\ \text { COLD CHEM-Receipt } & \text { A } 1.4900000\end{array}$
AQROXIDE FUSION-Receipt A 1.4400000
PEROXIDE FUSION-Product A 1.4233333
COLD CHEM-Product A 1.3900000
AQUA REGIA-Receipt A 1.3566667

Levels not connected by same letter are significantly different. 
Oneway Analysis of Measurement (Wt \%) By Prep Method Sample=ARG, Element=Na

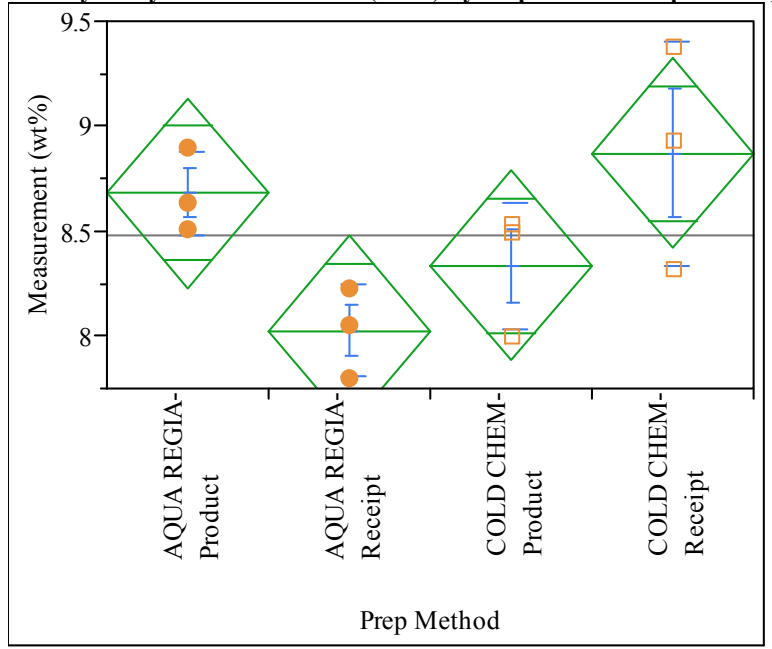

Missing Rows

Oneway Anova

$\begin{array}{lr}\text { Rsquare } & 0.576548 \\ \text { Adj Rsquare } & 0.417753 \\ \text { Root Mean Square Error } & 0.339362 \\ \text { Mean of Response } & 8.478333 \\ \text { Observations (or Sum Wgts) } & 12\end{array}$

Analysis of Variance

Source DF Sum of Squares Mean Square F Ratio Prob $>$ F

$\begin{array}{llllll}\text { Prep Method } & 3 & 1.2544333 & 0.418144 & 3.6308 & 0.0643\end{array}$

$\begin{array}{lrrr}\text { Error } & 8 & 0.9213333 & 0.115167 \\ \text { C. Total } & 11 & 2.1757667 & \end{array}$

Means for Oneway Anova

Level

AQUA REGIA-Product

AQUA REGIA-Receipt

Number Mean Std Error Lower 95\% Upper 95\% $\begin{array}{ll}8.2282 & 9.1318\end{array}$ $\begin{array}{llll}8.02667 & 0.19593 & 7.5748 & 8.4785\end{array}$ \begin{tabular}{llllll}
\hline COLD CHEM-Product & 3 & 8.33667 & 0.19593 & 7.8848 & 8.7885
\end{tabular} PEROXIDE FUSION-Product

PEROXIDE FUSION-Receipt

Std Error uses a pooled estimate of error variance

\section{Means and Std Deviations}

Level

AQUA REGIA-Receip

Number Mean Std Dev Std Err Mean Lower 95\% Upper 95\% COLD CHEM-Product

Level

COLD CHEM-Receipt

PEROXIDE FUSION-Product

Number Mean Std Dev Std Err Mean Lower 95\% Upper 95\%

PEROXIDE FUSION-Receip

Tests that the Variances are Equal

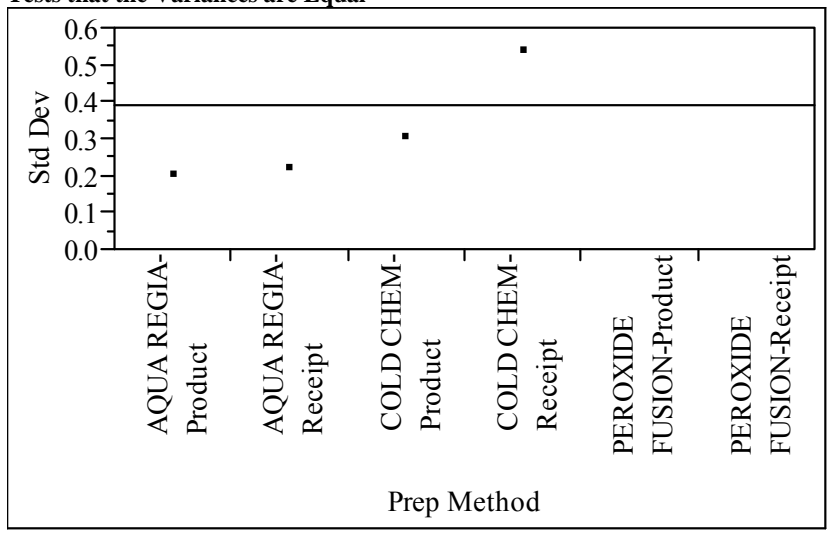

Level

AQUA REGIA-Product

AQUA REGIA-Receipt

Cou

COLD CHEM-Product

Count Std Dev Mean

anAbsDif

to Mean MeanAbsDif to Median

COLD CHEM-Receipt

PEROXIDE FUSION-Product

330.2159475

30.300887

0.1466667

$\begin{array}{ll}3 & 0.5325411\end{array}$

PEROXIDE FUSION-Receipt

0

0.2311111
0.3733333

0.0000000

0.0000000

0.1700000

0.2033333

0.1933333

0.5000000

0.0000000

Ratio DFNum DFDen Prob $>$ F

$\begin{array}{lllll}\text { OBrien[.5] } & 1.0093 & 3 & 8 & 0.4375 \\ \text { Brown-For } & 3.2356 & 3 & 8 & 0.018\end{array}$

$\begin{array}{lllll}\text { Brown-Forsythe } & 3.2356 & 3 & 8 & 0.0818\end{array}$

$\begin{array}{lllll}\text { Levene } & 1.2818 & 3 & 8 & 0.3448 \\ \text { Bartlett } & 0.7192 & 3 & . & 0.5403\end{array}$

Warning: Small sample sizes. Use Caution.

Welch Anova testing Means Equal, allowing Std Devs Not Equal

F Ratio DFNum DFDen Prob $>$ F

$\begin{array}{rrrr}4.4087 & 3 & 4.2961 & 0.0857\end{array}$

Means Comparisons

Comparisons for all pairs using Tukey-Kramer HSD

Level

COLD CHEM-Receipt A 8.870000

AQUA REGIA-P

AQUA REGIA-Product A 8.6800000

AQUA REGIA-Receipt A 8.0266667

Levels not connected by same letter are significantly different. 
Oneway Analysis of Measurement (Wt\%) By Prep Method Sample=ARG, Element=Ni

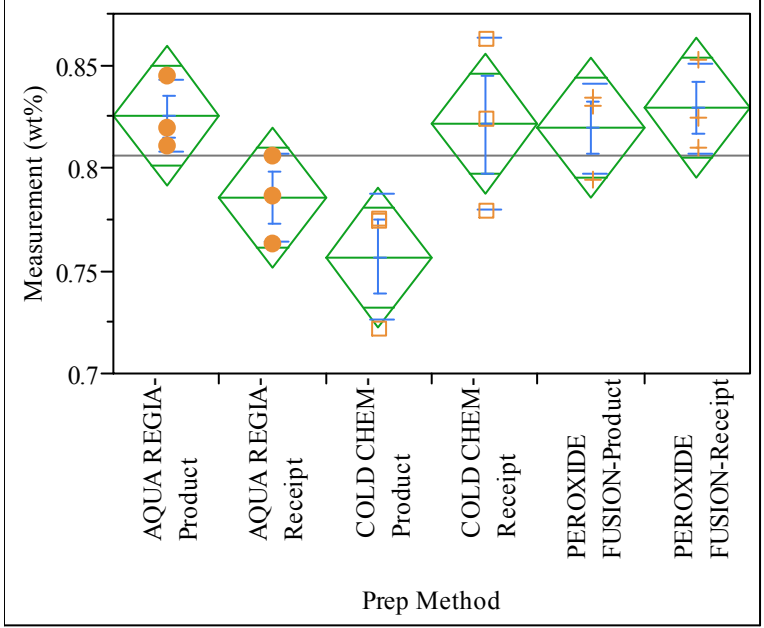

\section{Oneway Anova}

\section{Summary of Fit}

$\begin{array}{lr}\text { Rsquare } & 0.586338 \\ \text { Adj Rsquare } & 0.413979 \\ \text { Root Mean Square Error } & 0.027141 \\ \text { Mean of Response } & 0.806167 \\ \text { Observations (or Sum Wgts) } & 18\end{array}$

Analysis of Variance

DF Sum of Squares Mean Square F Ratio Prob $>$ F

$\begin{array}{lrrrrr}\text { Prep Method } & 5 & 0.01252917 & 0.002506 & 3.4018 & 0.0382\end{array}$

$\begin{array}{llll}\text { Error } & 12 & 0.00883933 & 0.000737\end{array}$

$\begin{array}{lll}\text { C. Total } & 17 & 0.02136850\end{array}$

Means for Oneway Anova

Level

Number Mean Std Error Lower 95\% Upper 95\% $\begin{array}{lrrr}0.825333 & 0.01567 & 0.79119 & 0.85947\end{array}$ $\begin{array}{llll}0.785333 & 0.01567 & 0.75119 & 0.81947\end{array}$ $\begin{array}{llll}\text { AQUA REGIA-Receipt } & 3 & 0.756667 & 0.01567\end{array}$ $\begin{array}{llll}\text { COLD CHEM-Product } & 3 & 0.7561333 & 0.01567\end{array}$ $\begin{array}{lllllll}\text { COLD CHEM-Receipt } & 3 & 0.821933 & 0.01567 & 0.78519 & 0.85347\end{array}$ $\begin{array}{llllll}\text { PEROXIDE FUSION-Receipt } & 3 & 0.829000 & 0.01567 & 0.79486 & 0.86314\end{array}$

Std Error uses a pooled estimate of error variance

\section{Means and Std Deviations}

Level

AQUA REGIA-Product

AQUA REGIA-Receipt $\begin{array}{rrrrrr}\text { Number } & \text { Mean } & \text { Std Dev } & \text { Std Err Mean } & \text { Lower 95\% } & \text { Upper 95\% } \\ 3 & 0.825333 & 0.017616 & 0.01017 & 0.78157 & 0.86909 \\ 3 & 0.785333 & 0.021548 & 0.01244 & 0.73180 & 0.83886\end{array}$ $\begin{array}{llllll}3 & 0.785333 & 0.021548 & 0.01244 & 0.73180 & 0.83886 \\ 3 & 0.756667 & 0.030892 & 0.01784 & 0.67993 & 0.83341\end{array}$ $\begin{array}{lrrrrrr}\text { Level } & \text { Number } & \text { Mean } & \text { Std Dev } & \text { Std Err Mean } & \text { Lower 95\% } & \text { Upper 95\% } \\ \text { COLD CHEM-Receipt } & 3 & 0.821333 & 0.041525 & 0.02397 & 0.71818 & 0.92449\end{array}$

$\begin{array}{lllllll}\text { PEROXIDE FUSION-Product } & 3 & 0.819333 & 0.022030 & 0.01272 & 0.76461 & 0.87406\end{array}$

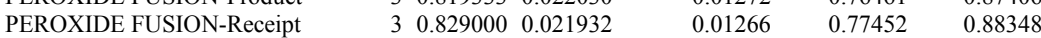

Tests that the Variances are Equal

\begin{tabular}{|c|c|c|c|c|c|c|}
\hline \multirow{4}{*}{ 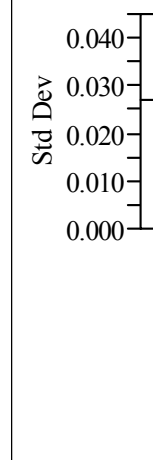 } & \multirow{2}{*}{\multicolumn{6}{|c|}{$\cdot$}} \\
\hline & & & & & & \\
\hline & & ' & & & " & • \\
\hline & 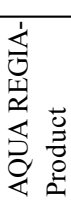 & 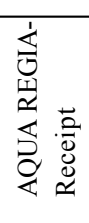 & 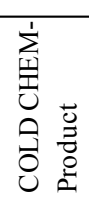 & 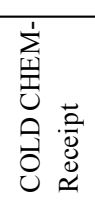 & 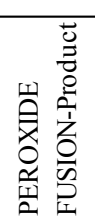 & 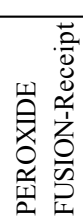 \\
\hline & & & Prep I & ethod & & \\
\hline
\end{tabular}

Level

AQUA REGIA-Product

0.88348

COLD CHEM-Product

COLD CHEM-Receipt

PEROXIDE FUSION-Product

$\begin{array}{rr}\text { Count Std Dev MeanAbsD } \\ 3 & 0.0176163\end{array}$

if to Mean MeanAbsDif to Median $\begin{array}{lll}3 & 0.0176163 \\ 3 & 0.0215484\end{array}$

0.0131111

30.041525

0.0148889
0.0237778

0.0143333

PEROXIDE FUSION-Receipt

30.0219317

0.0282222

0.0160000

0.0183333

0.0406667

0.0146667

0.0190000

$\begin{array}{lrrrr}\text { Test } & \text { F Ratio } & \text { DFNum } & \text { DFDen } & \text { Prob }>\text { F } \\ \text { O'Brien[.5] } & 0.6439 & 5 & 12 & 0.6713\end{array}$

$\begin{array}{lllll}\text { O'Brien[.5] } & 0.6439 & 5 & 12 & 0.6713 \\ \text { Brown-Forsythe } & 1.2225 & 5 & 12 & 0.3569 \\ \text { Lewn- } & 0.6379 & 5 & 12 & 0.6754\end{array}$

$\begin{array}{lllll}\text { Brown-Forsythe } & 1.2225 & 5 & 12 & 0.3569 \\ \text { Levene } & 0.6379 & 5 & 12 & 0.6754 \\ \text { Bartlett } & 0.3549 & 5 & & 0.8794\end{array}$

Warning: Small sample sizes. Use Caution.

Welch Anova testing Means Equal, allowing Std Devs Not Equal

F Ratio DFNum DFDen Prob > F

Means Comparisons

Comparisons for all pairs using Tukey-Kramer HSD

Level

Mean

PEROXIDE FUSION-Receipt A 0.82900000

AQUA REGIA-Product A 0.82533333

COLD CHEM-Receipt A 0.82133333

PEROXIDE FUSION-Product A 0.81933333
A 0.78533333

COLD CHEM-Product A 0.75666667 
Levels not connected by same letter are significantly different.

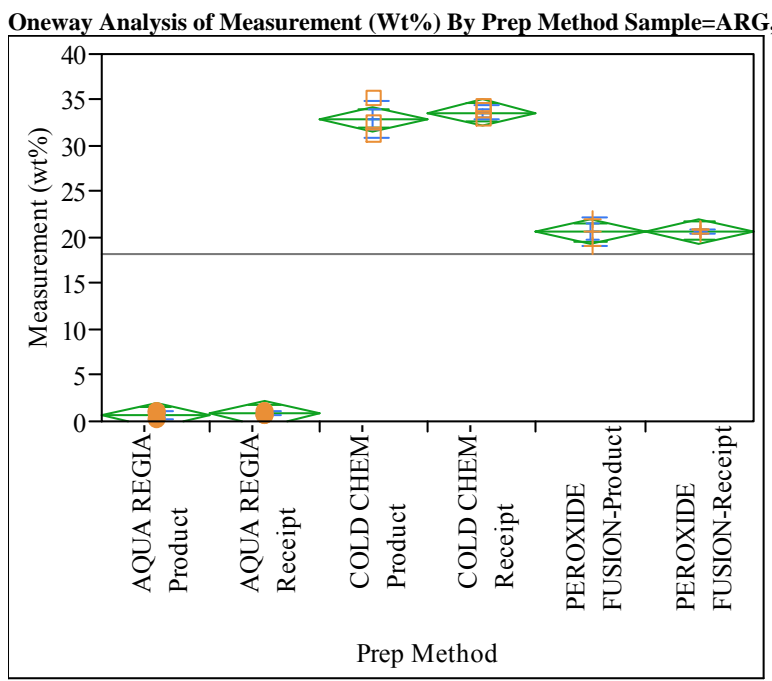

Oneway Anova

Summary of Fit

$\begin{array}{lr}\text { Rsquare } & 0.995608 \\ \text { Adj Rsquare } & 0.993778 \\ \text { Root Mean Square Error } & 1.089775 \\ \text { Mean of Response } & 18.23128 \\ \text { Observations (or Sum Wgts) } & 18\end{array}$

\section{Analysis of Variance}

Source DF Sum of Squares Mean Square F Ratio Prob $>$ F

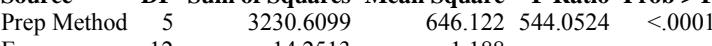

$\begin{array}{lrrr}\text { Error } & 12 & 14.2513 & 1.188 \\ \text { C. Total } & 17 & 3244.8612 & \end{array}$

\section{Means for Oneway Anova}

Number Mean Std Error Lower 95\% Upper 95\%

$\begin{array}{llllll}\text { AQUA REGIA-Product } & 3 & 0.6720 & 0.62918 & -0.70 & 2.043\end{array}$ $\begin{array}{llllll}\text { AQUA REGIA-Receipt } & 3 & 0.8157 & 0.62918 & -0.56 & 2.187\end{array}$

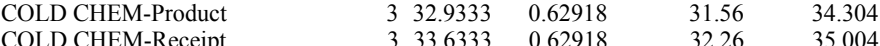
$\begin{array}{llllll}\text { PEROXIDE FUSION-Product } & 3 & 33.6333 & 0.62918 & 32.26 & 35.004 \\ & 3 & 20.6333 & 0.62918 & 19.26 & 22.004\end{array}$ $\begin{array}{lllll}\text { PEROXIDE FUSION-Receipt } & 3 & 20.7000 & 0.62918 & 19.33\end{array} 22.071$

Std Error uses a pooled estimate of error variance

\section{Means and Std Deviations}

Level

$\begin{array}{rrrrrr}\text { Number } & \text { Mean } & \text { Std Dev } & \text { Std Err Mean } & \text { Lower 95\% } & \text { Upper 95\% } \\ 3 & 0.6720 & 0.45778 & 0.2643 & -0.47 & 1.809\end{array}$

AQUA REGIA-Receip

0.2643

0.18

1.454
Level

COLD CHEM-Product

COLD CHEM-Receipt

PEROXIDE FUSION-Product

Number Mean Std Dev Std Err Mean Lower 95\% Upper 95\%

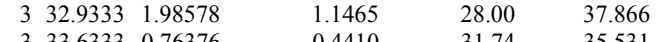

EROXIDE FUSION-Receip

$\begin{array}{llll}3 & 33.6333 & 0.76376 & 0.4410 \\ 3 & 20.6333 & 1.50111 & 0.8667\end{array}$

$\begin{array}{lll}0.8667 & 16.90 & 24.362\end{array}$

Tests that the Variances are Equa

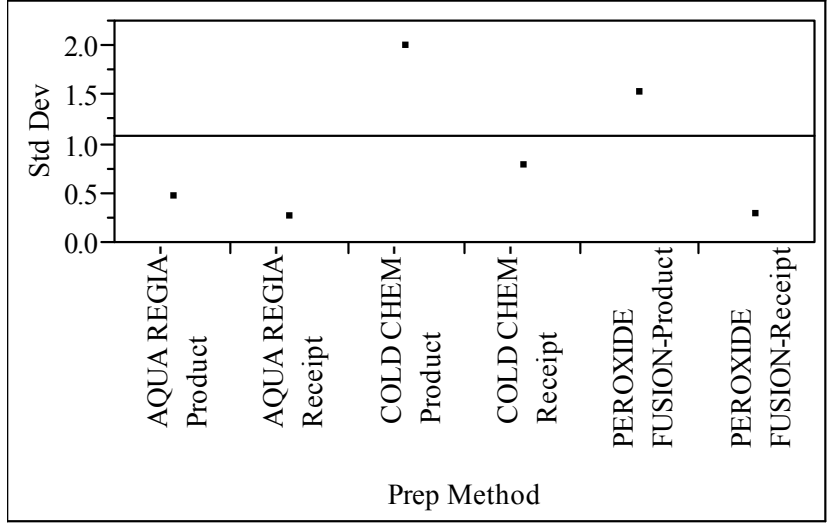

Level

AQUA REGIA-Product

AQUA REGIA-Receipt

Count

COLD CHEM-Product

$\begin{array}{ll}3 & 0.457781 \\ 3 & 0.257092\end{array}$

31.985783

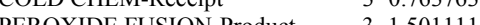

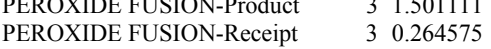

0.378000

$\begin{array}{ll}1.444444 & 0.180667 \\ 0.555556 & 1.733333\end{array}$

0.666667

1.022222

Test F Ratio DFNum DFDen Prob $>$ F

$\begin{array}{lrrrr}\text { O'Brien[.5] } & 1.2745 & 5 & 12 & 0.3365\end{array}$

$\begin{array}{lrrrr}\text { Brown-Forsythe } & 10.3809 & 5 & 12 & 0.0005 \\ \text { Levene } & 2.7511 & 5 & 12 & 0.0701\end{array}$

$\begin{array}{llrrr}\text { Levene } & 2.7511 & 5 & 12 & 0.0701 \\ \text { Bartlett } & 2.1181 & 5 & . & 0.0601\end{array}$

Warning: Small sample sizes. Use Caution.

Welch Anova testing Means Equal, allowing Std Devs Not Equal

F Ratio DFNum DFDen Prob >

$\begin{array}{lrrr}1787.0450 & 5 & 5.3731 & <.0001\end{array}$

Means Comparisons

Comparisons for all pairs using Tukey-Kramer HSD

Level

COLD CHEM-Receipt Mean

$\begin{array}{lll} & & \\ \text { COLD CHEM-Product } & \text { A } & 33.633333 \\ & \text { A } & 32.933333\end{array}$

$\begin{array}{lll}\text { PEROXIDE FUSION-Receipt A } & & 32.933333 \\ \text { B } & 20.700000\end{array}$

PEROXIDE FUSION-Product $\quad$ B 20.633333

$\begin{array}{lll}\text { AQUA REGIA-Receipt } & \text { C } & 0.815667\end{array}$

AQUA REGIA-Product $\quad$ C 0.672000 
Levels not connected by same letter are significantly different.

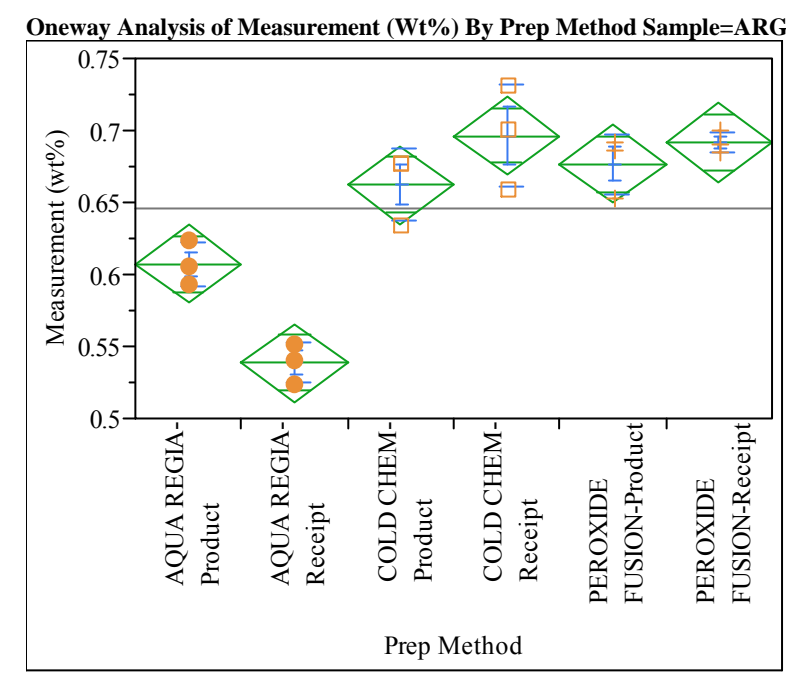

\section{Oneway Anova}

\section{Summary of Fit}

$\begin{array}{lr}\text { Rsquare } & 0.910471 \\ \text { Adj Rsquare } & 0.873167 \\ \text { Root Mean Square Error } & 0.021536 \\ \text { Mean of Response } & 0.645444 \\ \text { Observations (or Sum Wgts) } & 18\end{array}$

Analysis of Variance

DF Sum of Squares Mean Square F Ratio Prob $>$ F

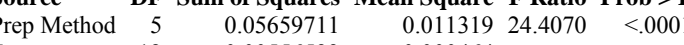

$\begin{array}{llll}\text { Error } & 12 & 0.00556533 & 0.00046\end{array}$

$\begin{array}{lll}\text { C. Total } & 17 & 0.06216244\end{array}$

Means for Oneway Anova

Leve

Number Mean Std Error Lower 95\% Upper 95\%

AQUA REGIA-PFOduct

$$
\begin{array}{lll}
3 & 0.607000 & 0.01243 \\
3 & 0.538667 & 0.01243
\end{array}
$$

$\begin{array}{ll}0.57991 & 0.63409\end{array}$

AQUA REGIA-Receip

$\begin{array}{llllll}\text { COLD CHEM-Product } & 3 & 0.662333 & 0.01243 & 0.63524 & 0.68942 \\ \text { COLD CHEM-Receipt } & 3 & 0.696333 & 0.01243 & 0.66924 & 0.72342\end{array}$

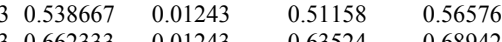

\begin{tabular}{lllllll}
\hline PEROXIDE FUSION-Product & 3 & 0.676667 & 0.01243 & 0.64958 & 0.70376
\end{tabular}

PEROXIDE FUSION-Recei

$30.691667 \quad 0.01243$

0.71876

Std Error uses a pooled estimate of error variance

\section{Means and Std Deviations}

Level

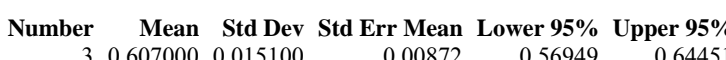

AQUA REGIA-Produc

$\begin{array}{lll}3 & 0.607000 & 0.015100 \\ 3 & 0.538667 & 0.014048\end{array}$

0.00872

0.56949

0.64451
Level

COLD CHEM-Product

PEROXIDE FUSION-Product

Number Mean Std Dev Std Err Mean Lower 95\% Upper 95\% $\begin{array}{llllll}3 & 0.662333 & 0.024542 & 0.01417 & 0.60137 & 0.72330\end{array}$ $\begin{array}{llllll}3 & 0.696333 & 0.035642 & 0.02058 & 0.60779 & 0.78487\end{array}$ $\begin{array}{llllll}3 & 0.676667 & 0.020648 & 0.01192 & 0.62537 & 0.72796\end{array}$

$\begin{array}{llllll}3 & 0.691667 & 0.007638 & 0.00441 & 0.67269 & 0.71064\end{array}$

Tests that the Variances are Equal

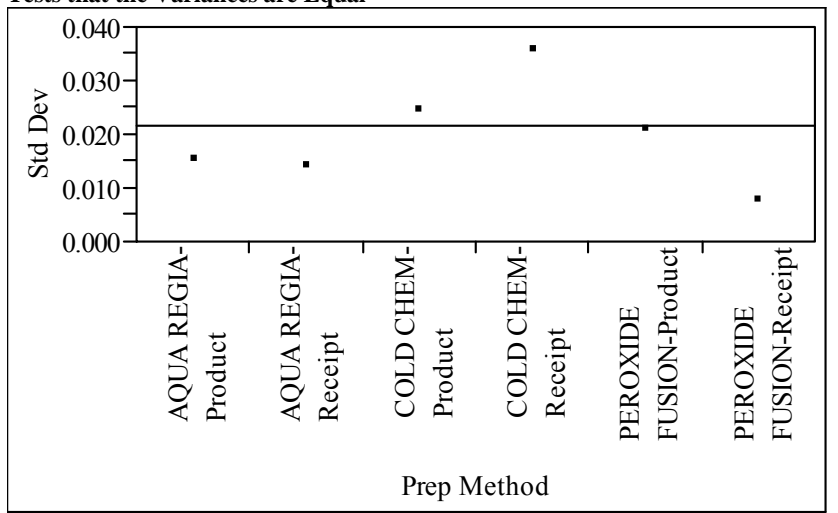

Level

AQUA REGIA-Product

AQUA REGIA-Receipt

\section{Count Std Dev MeanAbsDif to}

to Mean MeanAbsDif to Median

$\begin{array}{ll}3 & 0.0140475 \\ 3 & 0.0245425 \\ 3 & 0.0356417\end{array}$

0.0106667
0.0097778

0.0133333

PEROXIDE FUSION-P

roduct

$\begin{array}{ll}3 & 0.0356417 \\ 3 & 0.0206478\end{array}$

30.0076376

0.0188889

0.0248889

PEROXIDE FUSION-Receipt

0.0055556

Test F Ratio DFNum DFDen Prob > F

$\begin{array}{lllll}\text { O'Brien[.5] } & 0.9111 & 5 & 12 & 0.5056 \\ \text { Brown-Forsythe } & 1.6823 & 5 & 12 & 0.2132\end{array}$

$\begin{array}{lllll}\text { Brown-Forsythe } & 1.6823 & 5 & 12 & 0.2132 \\ \text { Levene } & 1.5118 & 5 & 12 & 0.2577\end{array}$

$\begin{array}{lllll}\text { Bartlett } & 0.8215 & 5 & . & 0.5341\end{array}$

Warning: Small sample sizes. Use Caution.

Welch Anova testing Means Equal, allowing Std Devs Not Equal

F Ratio DFNum DFDen Prob $>$ F

41.7048

Means Comparisons

Comparisons for all pairs using Tukey-Kramer HSD

Level

COLD CHEM-Receipt A $\quad 0.69633333$

PEROXIDE FUSION-Receipt A $\quad 0.69166667$

PEROXIDE FUSION-Product A $\quad 0.67666667$

COLD CHEM-Product A B 0.66233333

AQUA REGIA-Product $\quad$ B 0.60700000

AQUA REGIA-Receipt $\quad$ C 0.53866667 
Levels not connected by same letter are significantly different.

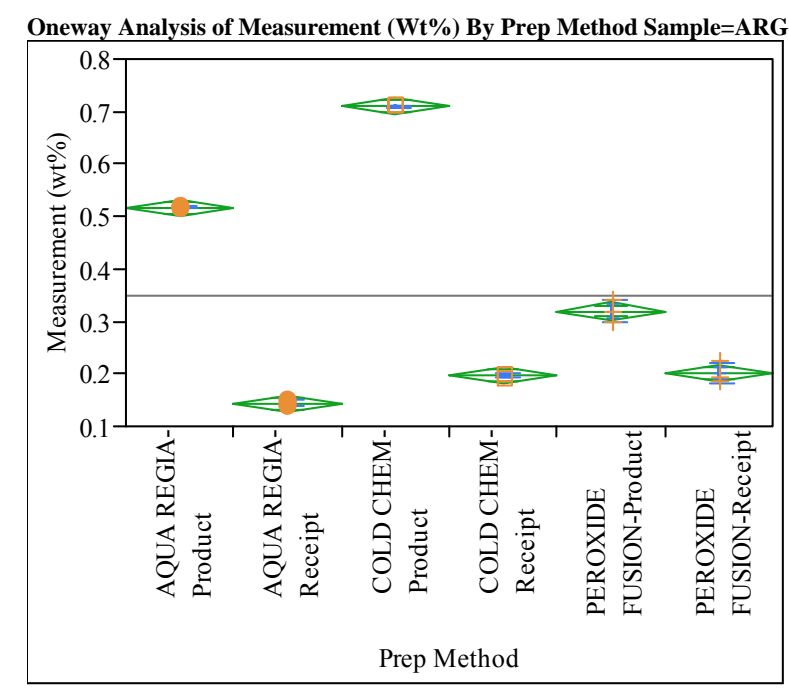

Oneway Anova

Summary of Fit

$\begin{array}{lr}\text { Rsquare } & 0.997383 \\ \text { Adj Rsquare } & 0.996293 \\ \text { Root Mean Square Error } & 0.012721 \\ \text { Mean of Response } & 0.348056 \\ \text { Observations (or Sum Wgts) } & 18\end{array}$

\section{Analysis of Variance}

Source DF Sum of Squares Mean Square F Ratio Prob $>$

$\begin{array}{lrrrrr}\text { Prep Method } & 5 & 0.74025494 & 0.148051 & 914.8362 & <.0001\end{array}$

$\begin{array}{lrrr}\text { Prep Method } & 5 & 0.74015494 & 0.1480162 \\ \text { Error } & 12 & 0.00194200 & 0.000162 \\ \text { C. Total } & 17 & 0.74219694 & \end{array}$

\section{Means for Oneway Anova}

Level

AQUA REGIA-Receipt

COLD CHEM-Product

COLD CHEM-Receipt

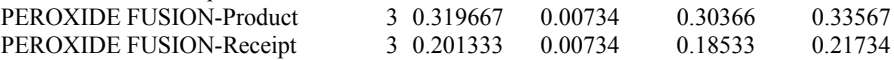

Number Mean Std Error Lower 95\% Upper 95\% $\begin{array}{llll}0.517333 & 0.00734 & 0.50133 & 0.53334\end{array}$ $\begin{array}{lllll}3 & 0.144000 & 0.00734 & 0.12800 & 0.16000\end{array}$ $\begin{array}{lllll}3 & 0.710000 & 0.00734 & 0.69400 & 0.72600\end{array}$ $\begin{array}{lllll}3 & 0.196000 & 0.00734 & 0.18000 & 0.21200\end{array}$

Std Error uses a pooled estimate of error variance

\section{Means and Std Deviations}

Level

AQUA REGIA-Product

$\begin{array}{rrrrrr}\text { Number } & \text { Mean } & \text { Std Dev } & \text { Std Err Mean } & \text { Lower 95\% } & \text { Upper 95\% } \\ 3 & 0.517333 & 0.002309 & 0.00133 & 0.51160 & 0.52307\end{array}$

AQUA REGIA-Receipt

0.13086
Level

COLD CHEM-Product

PEROXIDE FUSION-Product

Number Mean Std Dev Std Err Mean Lower 95\% Upper 95\% $\begin{array}{llllll}3 & 0.710000 & 0.001732 & 0.00100 & 0.70570 & 0.71430\end{array}$

ROXIDE FUSION-Receipt

$\begin{array}{lll}0.00252 & 0.18517 & 0.20683\end{array}$

$\begin{array}{llllll}3 & 0.319667 & 0.022121 & 0.01277 & 0.26472 & 0.37462\end{array}$

$\begin{array}{lll}3 & 0.201333 & 0.020648\end{array}$

$0.01192 \quad 0.15004$

0.25263

Tests that the Variances are Equal

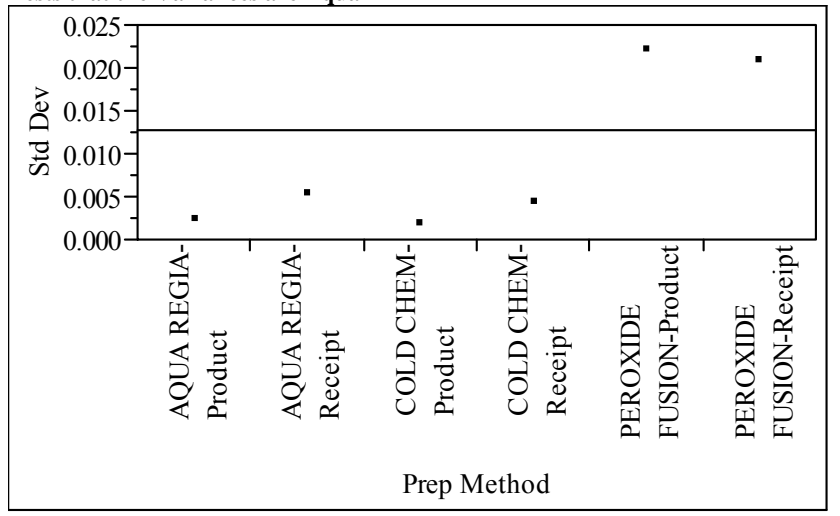

Level
AQUA REGIA-Product

Count Std Dev MeanAbsDif to Mean MeanAbsDif to Median

AQUA REGIA-ReC

$0.0017778-0.0013333$

COLD CHEM-Produc

$\begin{array}{ll}3 & 0.0023094 \\ 3 & 0.0052915 \\ 3 & 0.0017321\end{array}$

$\begin{array}{lll}3 & 0.0052915 \\ 3 & 0.0017321 \\ 3\end{array}$

30.0043589

PEROXIDE FUSION-Product

30.0221209

0.0040000

0.0013333

0.0040000

PEROXIDE FUSION-Receipt

30.0206478

0.0033333

0.0157778

0.0030000

0.0206667

Test F Ratio DFNum DFDen Prob $>$ F

$\begin{array}{lllll}\text { O'Brien[.5] } & 1.3397 & 5 & 12 & 0.3127 \\ & 3.80780 & 5 & 12 & 0.0269\end{array}$

$\begin{array}{lllll}\text { Brown-Forsythe } & 3.8030 & 5 & 12 & 0.0269 \\ \text { Levene } & 4.4782 & 5 & 12 & 0.0156\end{array}$

$\begin{array}{lllll}\text { Bartlett } & 3.0883 & 5 & .0 .0086\end{array}$

Warning: Small sample sizes. Use Caution.

Welch Anova testing Means Equal, allowing Std Devs Not Equal

$\begin{array}{rrrr}\text { F Ratio } & \text { DFNum } & \text { DFDen } & \text { Prob }>\text { F } \\ 5521.4347 & 5 & <.3039 & <.0001\end{array}$

Means Comparisons

Comparisons for all pairs using Tukey-Kramer HSD

Level

COLD CHEM-Product A $\quad 0.71000000$

AQUA REGIA-Product B $\quad 0.5173333$

PEROXIDE FUSION-Product $\quad$ C $\quad 0.31966667$

PEROXIDE FUSION-Receipt $\quad$ D 0.2013333

COLD CHEM-Receipt D 0.19600000

AQUA REGIA-Receipt $\quad$ E 0.14400000 
Levels not connected by same letter are significantly different.

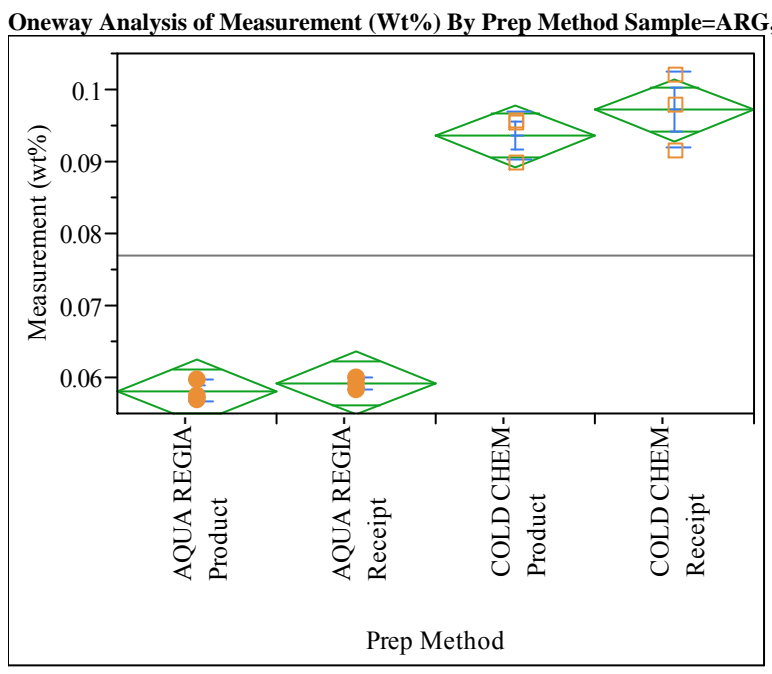

Missing Rows

Oneway Anova

Summary of Fit

Rsquare

0.979728

Adj Rsquare

0.972126

Root Mean Square Error $\quad 0.003241$

Mean of Respons

0.076967

Analysis of Variance

DF Sum of Squares Mean Square F Ratio Prob >

$\begin{array}{lllllll}\text { Prep Method } 3 & 0.00406157 & 0.001354 & 128.8773 & <.000\end{array}$

$\begin{array}{lrrr}\text { Error } & 8 & 0.00008404 & 0.00001 \\ \text { C. Total } & 11 & 0.00414561 & \end{array}$

$\begin{array}{lll}\text { C. Total } & 11 & 0.00414561\end{array}$

Means for Oneway Anova

$\begin{array}{rrrrr}\text { Number } & \text { Mean } & \text { Std Error } & \text { Lower 95\% } & \text { Upper 95\% } \\ 3 & 0.058067 & 0.00187 & 0.05375 & 0.06238\end{array}$

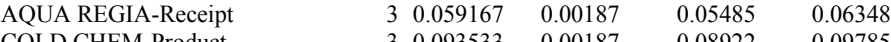

$\begin{array}{llllll}\text { COLD CHEM-Product } & 3 & 0.093533 & 0.00187 & 0.08922 & 0.09785 \\ \text { COLD CHEM-Receipt } & 3 & 0.097100 & 0.00187 & 0.09278 & 0.10142\end{array}$

PEROXIDE FUSION-Product

$0.097100 \quad 0.00187$

0.10142

PEROXIDE FUSION-Receipt

Std Error uses a pooled estimate of error variance

Means and Std Deviations

Level

Number Mean Std Dev Std Err Mean Lower 95\% Upper 95\%
Level

AQUA REGIA-Receipt

COLD CHEM-Product

PEROXIDE FUSION-Product

Number Mean Std Dev Std Err Mean Lower 95\% Upper 95\% $\begin{array}{llllll}3 & 0.059167 & 0.000850 & 0.00049 & 0.05705 & 0.06128\end{array}$ $\begin{array}{llllll}3 & 0.093533 & 0.003320 & 0.00192 & 0.08529 & 0.10178\end{array}$ $\begin{array}{lll}3 & 0.097100 & 0.005285\end{array}$

$0.00305 \quad 0.08397$

0.11023

Tests that the Variances are Equal

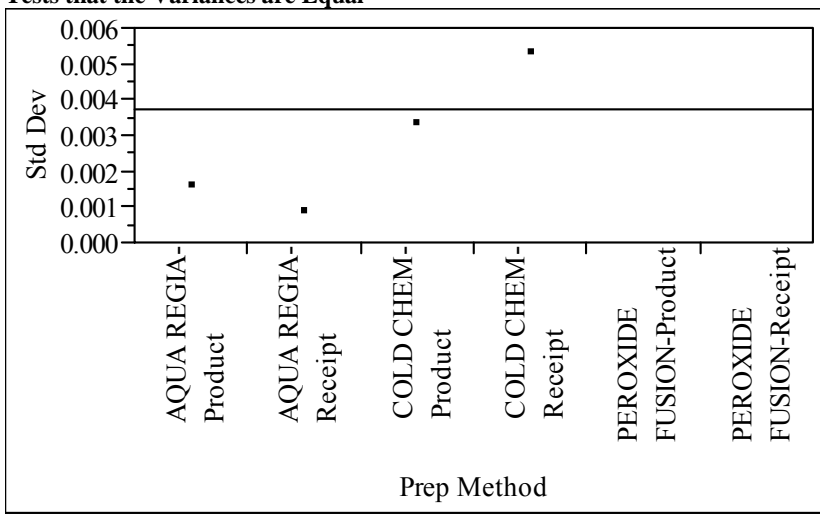

Level

AQUA REGIA-Product

Std Dev MeanAbsDif to Mean MeanAbsDif to Median

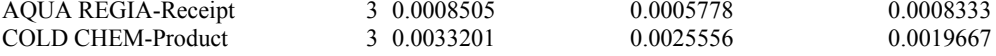

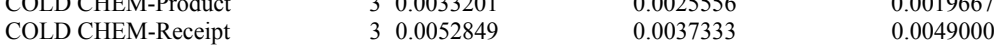

$\begin{array}{llll}\text { PEROXIDE FUSION-Product } & 0 & 0.0037333 & 0.0049000 \\ \text { PEROXIDE } & 0.0000000 & 0.0000000\end{array}$

$\begin{array}{llll}\text { PEROXIDE FUSION-Receipt } & 0 & \text {. } & 0.0000000\end{array}$

Test F Ratio DFNum DFDen Prob $>$ F

$\begin{array}{lllll}\text { O'Brien[.5] } & 1.2175 & 3 & 8 & 0.3644 \\ \text { Brown-Forsythe } & 3.1897 & 3 & 8 & 0.0842 \\ \text { Levene } & 2.7453 & 3 & 8 & 0.1127\end{array}$

$\begin{array}{lllll}\text { Levene } & 2.7453 & 3 & 8 & 0.1127 \\ \text { Bartlett } & 1.7379 & 3 & & 0.1568\end{array}$

Warning: Small sample sizes. Use Caution.

Welch Anova testing Means Equal, allowing Std Devs Not Equal

F Ratio DFNum DFDen Prob $>$ F
112.4765

Means Comparisons

Comparisons for all pairs using Tukey-Kramer HSD

$\begin{array}{lr}\text { Level } & \text { Mean } \\ \text { COLD CHEM-Receipt A } & 0.09710000\end{array}$

COLD CHEM-Product A 0.09353333

AQUA REGIA-Receipt $\quad$ B 0.05916667

AQUA REGIA-Product B 0.05806667

Levels not connected by same letter are significantly different. 
Oneway Analysis of Measurement (Wt\%) By Prep Method Sample=SRAT Product, Element=AI

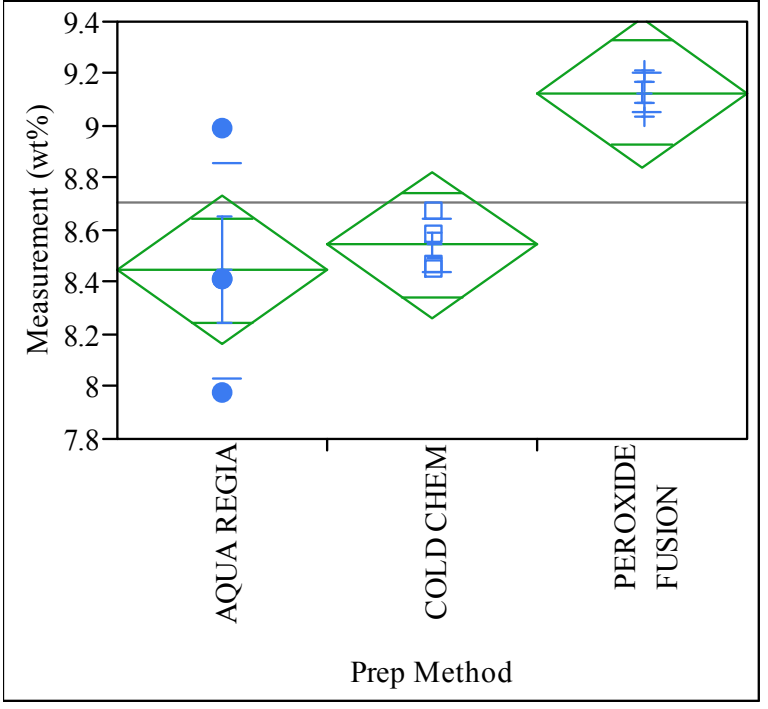

Oneway Anova

$\begin{array}{lr}\text { Rsquare } & 0.657618 \\ \text { Adj Rsquare } & 0.581533 \\ \text { Root Mean Square Error } & 0.250516 \\ \text { Mean of Response } & 8.705833 \\ \text { Observations (or Sum Wgts) } & 12\end{array}$

\section{Analysis of Variance}

Source DF Sum of Squares Mean Square F Ratio Prob $>$ F

$\begin{array}{lrrrrr}\text { Prep Method } & 2 & 1.0848667 & 0.542433 & 8.6432 & 0.0080\end{array}$

$\begin{array}{lrr}\text { C. Total } & 11 & 0.5648250 \\ & & 1.6496917\end{array}$

\section{Means for Oneway Anova}

Level Number Mean Std Error Lower 95\% Upper 95\%

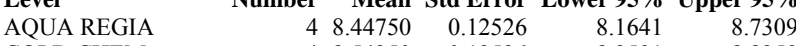

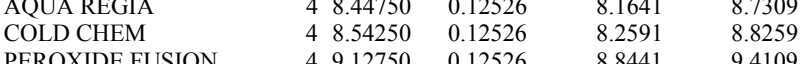

Std Error uses a pooled estimate of error variance

\section{Means and Std Deviations}

$\begin{array}{lrrrrrr}\text { Level } & \text { Number } & \text { Mean } & \text { Std Dev } & \text { Std Err Mean } & \text { Lower 95\% } & \text { Upper 95\% } \\ \text { AQUA REGIA } & 4 & 8.44750 & 0.414598 & 0.20730 & 7.7878 & 9.1072 \\ \text { COLD CHEM } & 4 & 8.54250 & 0.102429 & 0.05121 & 8.3795 & 8.7055\end{array}$ $\begin{array}{lllllll}\text { COLD CHEM } & 4 & 8.54250 & 0.102429 & 0.05121 & 8.3795 & 8.7055 \\ \text { PEROXIDE FUSION } & 4 & 9.12750 & 0.076757 & 0.03838 & 9.0054 & 9.2496\end{array}$
Tests that the Variances are Equal

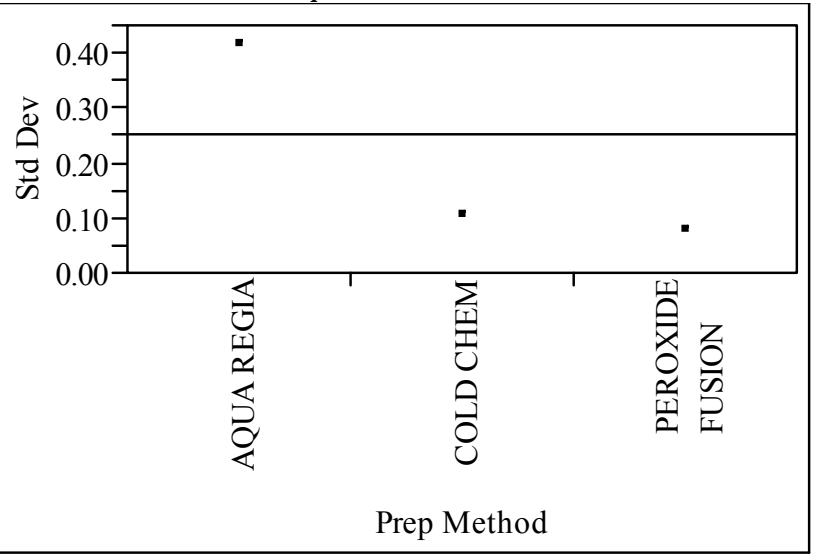

Level

Count Std Dev MeanAbsDif to Mean MeanAbsDif to Median

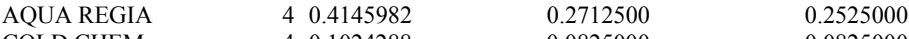

$\begin{array}{lllll}\text { COLD CHEM } & 4 & 0.1024288 & 0.0825000 & 0.0825000 \\ \text { PEROXIDE FUSION } & 4 & 0.0767572 & 0.0625000 & 0.0625000\end{array}$

Test F Ratio DFNum DFDen Prob $>$ F

$\begin{array}{lllll}\text { O'Brien[.5] } & 1.7020 & 2 & 9 & 0.2361\end{array}$

$\begin{array}{lllll}\text { Brown-Forsythe } & 1.4330 & 2 & 9 & 0.2882\end{array}$

$\begin{array}{lllll}\text { Levene } & 2.0979 & 2 & 9 & 0.1787 \\ \text { Bartlett } & 4.1113 & 2 & . & 0.0164\end{array}$

Warning: Small sample sizes. Use Caution.

Welch Anova testing Means Equal, allowing Std Devs Not Equal

F Ratio DFNum DFDen Prob > F

$\begin{array}{rrrr}39.3179 & 2 & 5.2737 & 0.0007\end{array}$

Means Comparisons

Comparisons for all pairs using Tukey-Kramer HSD

$\begin{array}{lr}\text { Level } & \text { Mean } \\ \text { PEROXIDE FUSION A } & 9.1275000\end{array}$

COLD CHEM $\quad$ B 8.5425000

AQUA REGIA $\quad$ B 8.4475000

Levels not connected by same letter are significantly different. 
Oneway Analysis of Measurement (Wt\%) By Prep Method Sample=SRAT Product, Element=B

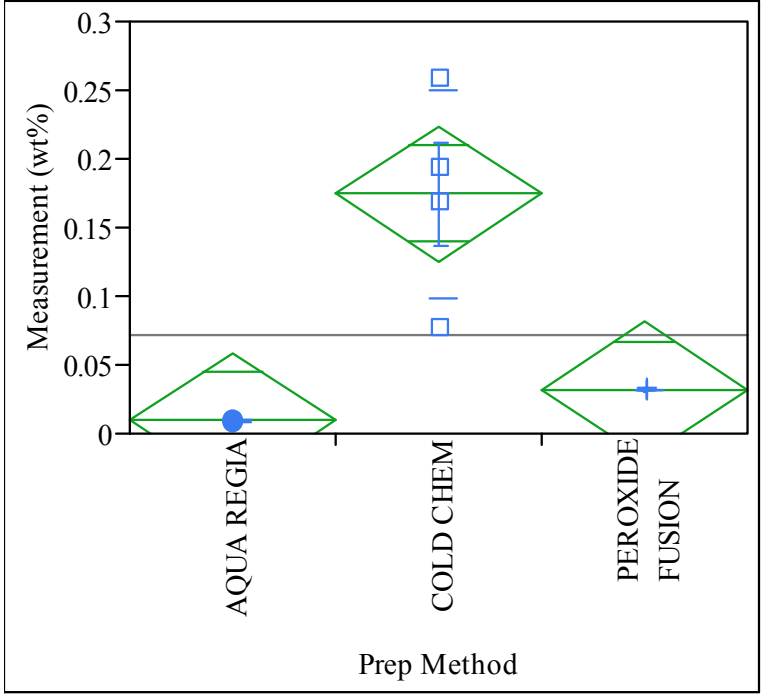

Oneway Anova

Summary of Fit

$\begin{array}{lr}\text { Rsquare } & 0.78869 \\ \text { Adj Rsquare } & 0.741732 \\ \text { Root Mean Square Error } & 0.04368 \\ \text { Mean of Response } & 0.071829 \\ \text { Observations (or Sum Wgts) } & 12\end{array}$

Analysis of Variance

Source DF Sum of Squares Mean Square F Ratio Prob $>$ F

$\begin{array}{lllllll}\text { Prep Method } & 2 & 0.06409182 & 0.032046 & 16.7957 & 0.0009\end{array}$

$\begin{array}{lrrr}\text { Error } & 9 & 0.01717183 & 0.001908 \\ \text { C. Total } & 11 & 0.08126364 & \end{array}$

Means for Oneway Anova

$\begin{array}{lrrrrr}\text { Level } & \text { Number } & \text { Mean } & \text { Std Error } & \text { Lower 95\% } & \text { Upper 95\% } \\ \text { AQUA REGIA } & 4 & 0.009388 & 0.02184 & -0.0400 & 0.05879 \\ \text { COLD CHEM } & 4 & 0.174375 & 0.02184 & 0.1250 & 0.22378 \\ \text { PEROXIDE FUSION } & 4 & 0.031725 & 0.02184 & -0.0177 & 0.08113\end{array}$

Std Error uses a pooled estimate of error variance

\section{Means and Std Deviations}

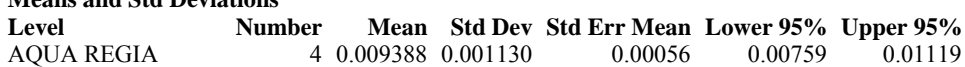

$\begin{array}{llllllr}\text { AQUA REGIA } & 4 & 0.009388 & 0.001130 & 0.00056 & 0.00759 & 0.01119 \\ \text { COLD CHEM } & 4 & 0.174375 & 0.075645 & 0.03782 & 0.05401 & 0.29474\end{array}$

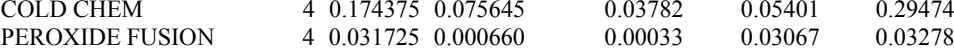

Tests that the Variances are Equal

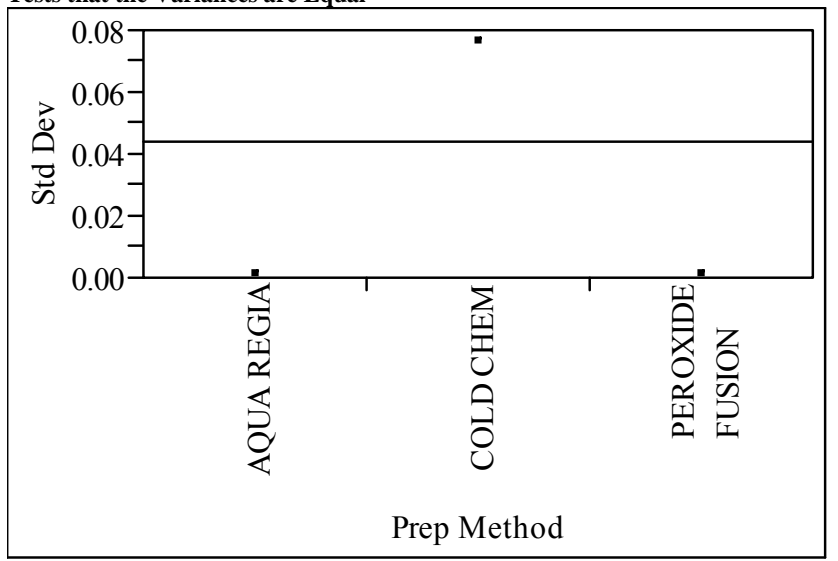

Level

Count Std Dev MeanAbsDif to Mean MeanAbsDif to Median

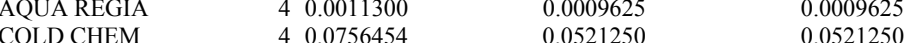

$\begin{array}{lllll}\text { COLD CHEM } & 4 & 0.0756454 & 0.0521250 & 0.0521250 \\ \text { PEROXIDE FUSION } & 4 & 0.0006602 & 0.0005250 & 0.0005250\end{array}$

Test F Ratio DFNum DFDen Prob $>$ F

$\begin{array}{lllll}\text { O'Brien[.5] } & 2.0339 & 2 & 9 & 0.1867\end{array}$

$\begin{array}{lllll}\text { Brown-Forsythe } & 4.8933 & 2 & 9 & 0.0365 \\ \text { Levene } & 5.0297 & 2 & 9 & 0.0342\end{array}$

$\begin{array}{lrrrr}\text { Bartlett } & 19.0681 & 2 & < & <.0001\end{array}$

Warning: Small sample sizes. Use Caution.

Welch Anova testing Means Equal, allowing Std Devs Not Equal

$\begin{array}{rrrrr}\text { F Ratio } & \text { DFNum } & \text { DFDen } & \text { Prob }>\text { F } \\ 520.1086 & 2 & 4.9367 & <.0001\end{array}$

Means Comparisons

Comparisons for all pairs using Tukey-Kramer HSD

Level

COLD CHEM A $\quad 0.17437500$

PEROXIDE FUSION B 0.03172500

AQUA REGIA $\quad$ B 0.00938750

Levels not connected by same letter are significantly different. 
Oneway Analysis of Measurement (Wt\%) By Prep Method Sample=SRAT Product, Element=Ca

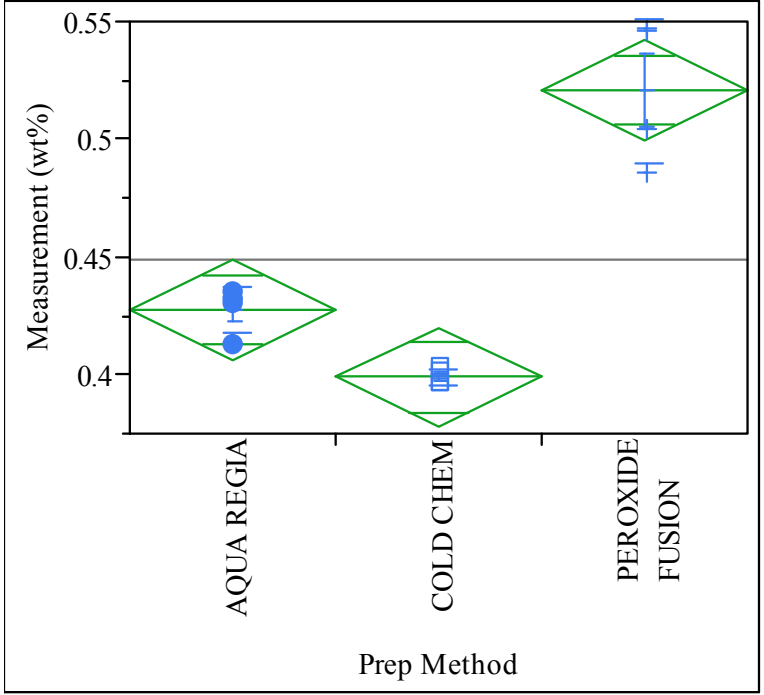

Oneway Anova

Summary of Fit

$\begin{array}{lr}\text { Rsquare } & 0.911604 \\ \text { Adj Rsquare } & 0.89196 \\ \text { Root Mean Square Error } & 0.018696 \\ \text { Mean of Response } & 0.449083 \\ \text { Observations (or Sum Wgts) } & 12\end{array}$

Analysis of Variance

Source DF Sum of Squares Mean Square F Ratio Prob $>$ F

$\begin{array}{lllllll}\text { Prep Method } & 2 & 0.03244117 & 0.016221 & 46.4071 & <.0001\end{array}$

$\begin{array}{lrrr}\text { Error } & 9 & 0.00314575 & 0.000350 \\ \text { C. Total } & 11 & 0.03558692\end{array}$

Means for Oneway Anova

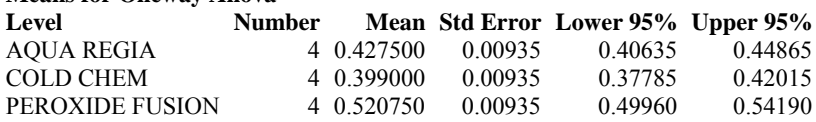

Std Error uses a pooled estimate of error variance

\section{Means and Std Deviations}

Level $\quad$ Number Mean Std Dev Std Err Mean Lower 95\% Upper 95\%

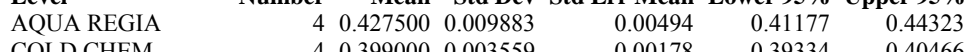

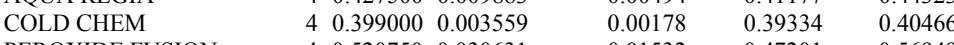

$\begin{array}{lllllll}\text { PEROXIDE FUSION } & 4 & 0.520750 & 0.030631 & 0.01532 & 0.47201 & 0.56949\end{array}$
Tests that the Variances are Equal

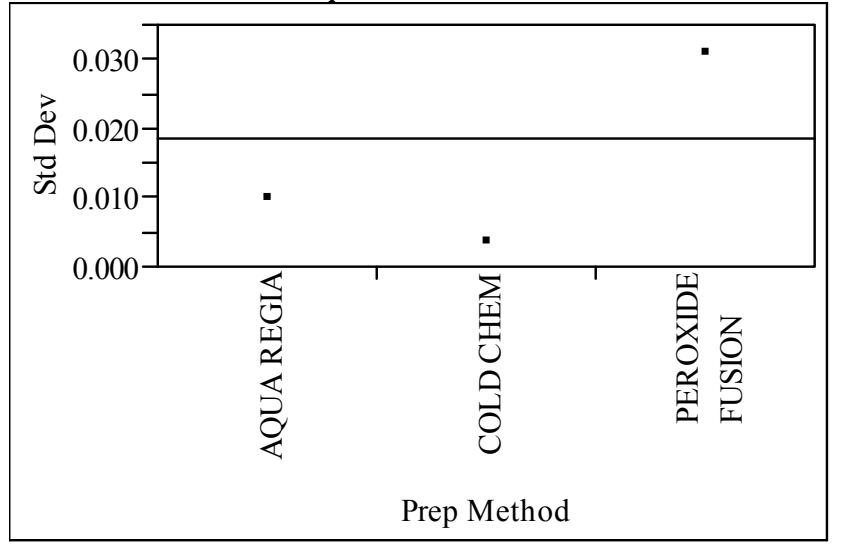

Level Count Std Dev MeanAbsDif to Mean MeanAbsDif to Median

$\begin{array}{llll}\text { AQUA REGIA } & 40.0098826 & 0.0072500 & 0.0060000 \\ \text { COLD CHEM } & 40.0035590 & 0.0030000 & 0.0030000\end{array}$

$\begin{array}{lll}\text { CEROXIDE FUSION } \quad 40.0306309 & 0.003000 & 0.003000\end{array}$

Test F Ratio DFNum DFDen Prob $>$ F

$\begin{array}{lrrrr}\text { O'Brien[.5] } & 7.3119 & 2 & 9 & 0.0130 \\ \text { Brown-Forsythe } & 12.6213 & 2 & 9 & 0.0024 \\ & 21.3033 & 2 & 9 & 0.0004\end{array}$

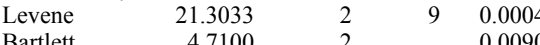

Waring Small sample sizes. Use Caulon.

Welch Anova testing Means Equal, allowing Std Devs Not Equal

F Ratio DFNum DFDen Prob > F

$\begin{array}{llll}38.5758 & 2 & 4.499 & 0.0015\end{array}$

Means Comparisons

Comparisons for all pairs using Tukey-Kramer HSD

Level Mean

PEROXIDEFUSION A 0.52075000

AQUA REGIA $\quad$ B 0.42750000

Levels not connected by same letter are significantly different. 
Oneway Analysis of Measurement (Wt\%) By Prep Method Sample=SRAT Product, Element=Cr

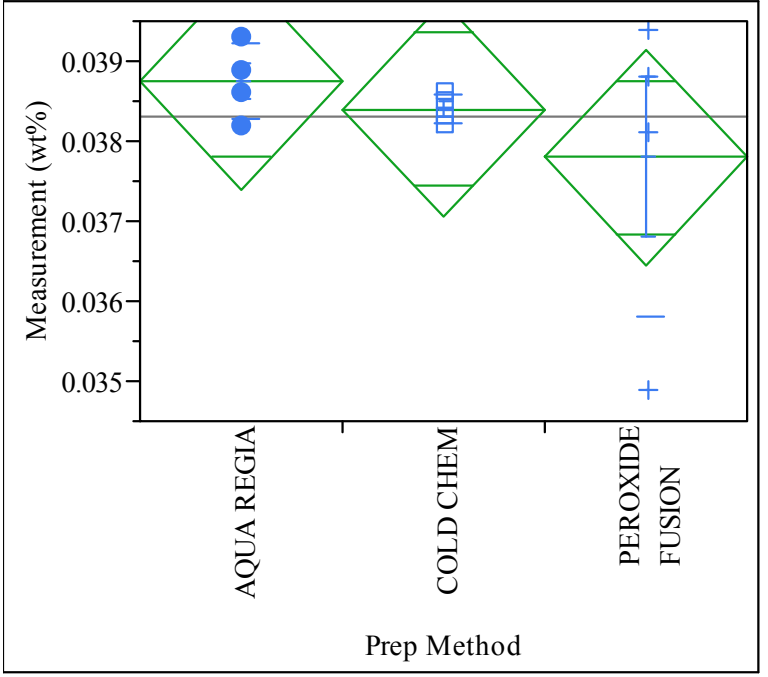

Oneway Anova

Summary of Fit

$\begin{array}{lr}\text { Rsquare } & 0.125995 \\ \text { Adj Rsquare } & -0.06823 \\ \text { Root Mean Square Error } & 0.001193 \\ \text { Mean of Response } & 0.038317 \\ \text { Observations (or Sum Wgts) } & 12\end{array}$

0.038317

Analysis of Variance

Source DF Sum of Squares Mean Square F Ratio Prob $>$ F

$\begin{array}{lrrrrr}\text { Source } & \text { DF } & \text { Sum of Squares } & \text { Mean Square F Ratio Prob }>\text { F } \\ \text { Prep Method } & 2 & 0.00000185 & 9.2333 \mathrm{e}-7 & 0.6487 & 0.5455\end{array}$

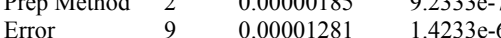

$\begin{array}{lrr}\text { C. Total } & 11 & 0.00001466\end{array}$

Means for Oneway Anova

Level Number Mean Std Error Lower 95\% Upper 95\%

$\begin{array}{llllll}\text { AQUA REGIA } & 4 & 0.038750 & 0.00060 & 0.03740 & 0.04010\end{array}$

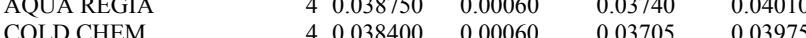

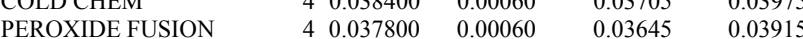

Std Error uses a pooled estimate of error variance

$\begin{array}{lrrrrrr}\text { Means and Std Deviations } & & & & & & \\ \text { Level } & \text { Number } & \text { Mean } & \text { Std Dev } & \text { Std Err Mean } & \text { Lower 95\% } & \text { Upper 95\% } \\ \text { AQUA REGIA } & 4 & 0.038750 & 0.000465 & 0.00023 & 0.03801 & 0.03949 \\ \text { COLD CHEM } & 4 & 0.038400 & 0.000183 & 9.13 \mathrm{e}-5 & 0.03811 & 0.03869 \\ \text { PEROXIDE FUSION } & 4 & 0.037800 & 0.002005 & 0.00100 & 0.03461 & 0.04099\end{array}$

Tests that the Variances are Equal

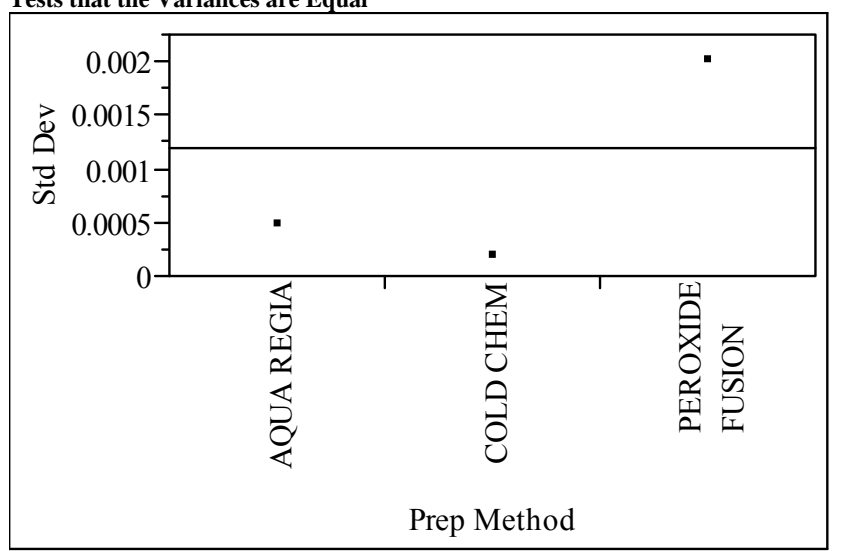

$\begin{array}{lrrrr}\text { Level } & \text { Count } & \text { Std Dev } & \text { MeanAbsDif to Mean } & \text { MeanAbsDif to Median } \\ \text { AQUA REGIA } & 4 & 0.0004655 & 0.0003500 & 0.0003500 \\ \text { COLD CHEM } & 4 & 0.0001826 & 0.0001500 & 0.0001500\end{array}$

Count Std Dev MeanAbsDif to Mean MeanAbsDif to Median

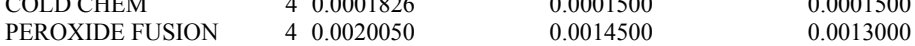

Test F Ratio DFNum DFDen Prob $>$ F

$\begin{array}{lrrrr}\text { O'Brien[.5] } & 1.5627 & 2 & 9 & 0.2615 \\ \text { Brown-Forsythe } & 1.8980 & 2 & 9 & 0.2052 \\ \text { Lewe } & 4.6178 & 2 & 9 & 0.0417\end{array}$

$\begin{array}{lllll}\text { Brown-Forsythe } & 1.8980 & 2 & 9 & 0.2052 \\ \text { Levene } & 4.6178 & 2 & 9 & 0.0417\end{array}$

Bartlett - 6.0075

Warning: Small sample sizes. Use Caution.

Welch Anova testing Means Equal, allowing Std Devs Not Equal

F Ratio DFNum DFDen Prob $>$ F

$\begin{array}{llll}2 & 4.5506 & 0.4261\end{array}$

Means Comparisons

Comparisons for all pairs using Tukey-Kramer HSD

$\begin{array}{lr}\text { Level } & \text { Mean } \\ \text { AQUA REGIA } & \text { A } 0.03875000\end{array}$

AQUA REGIA A 0.03875000

PEROXIDE FUSION A 0.03780000

Levels not connected by same letter are significantly different. 
Oneway Analysis of Measurement (Wt\%) By Prep Method Sample=SRAT Product, Element=Cu

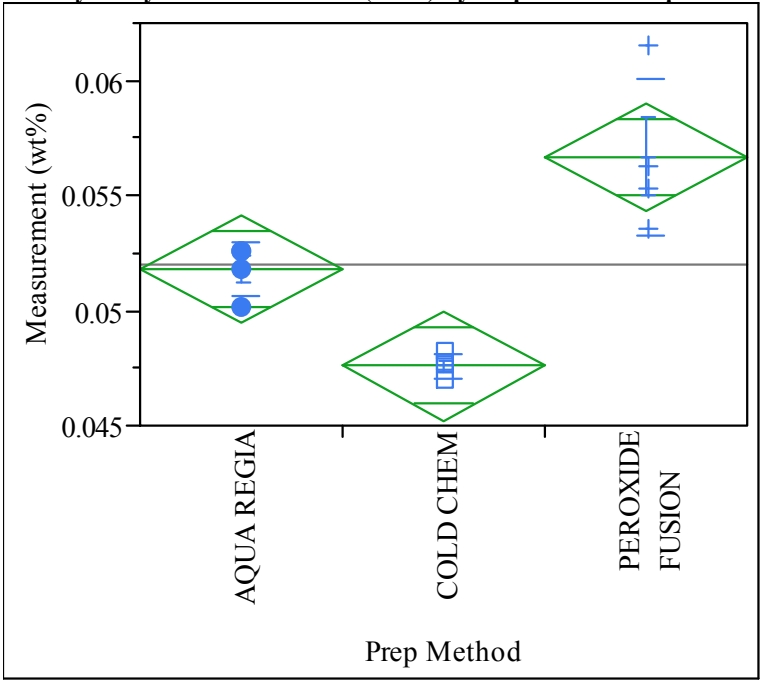

Oneway Anova

Summary of Fit

$\begin{array}{lr}\text { Rsquare } & 0.806988 \\ \text { Adj Rsquare } & 0.764097 \\ \text { Root Mean Square Error } & 0.002094 \\ \text { Mean of Response } & 0.052025 \\ \text { Observations (or Sum Wgts) } & 12\end{array}$

Analysis of Variance

Source DF Sum of Squares Mean Square F Ratio Prob > F

$\begin{array}{lrrrrr}\text { Source } & \text { DF } & \text { Sum of Squares } & \text { Mean Square } & \text { F Ratio } & \text { Prob }>\text { F } \\ \text { Prep Method } & 2 & 0.00016502 & 0.000083 & 18.8147 & 0.0006\end{array}$

$\begin{array}{llll}\text { Error } & 9 & 0.00003947 & 4.385 \mathrm{e}-6\end{array}$

$\begin{array}{lrr}\text { C. Total } & 11 & 0.00020448\end{array}$

Means for Oneway Anova

Level Number Mean Std Error Lower 95\% Upper 95\%

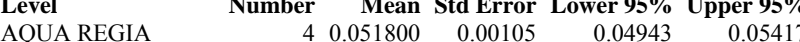

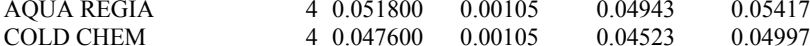

$\begin{array}{llllll}\text { PEROXIDE FUSION } & 4 & 0.056675 & 0.00105 & 0.05431 & 0.05904\end{array}$

Std Error uses a pooled estimate of error variance

\section{Means and Std Deviations}

Level Number Mean Std Dev Std Err Mean Lower 95\% Upper 95\%

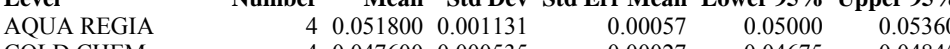

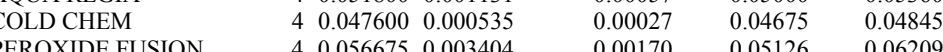

Tests that the Variances are Equal

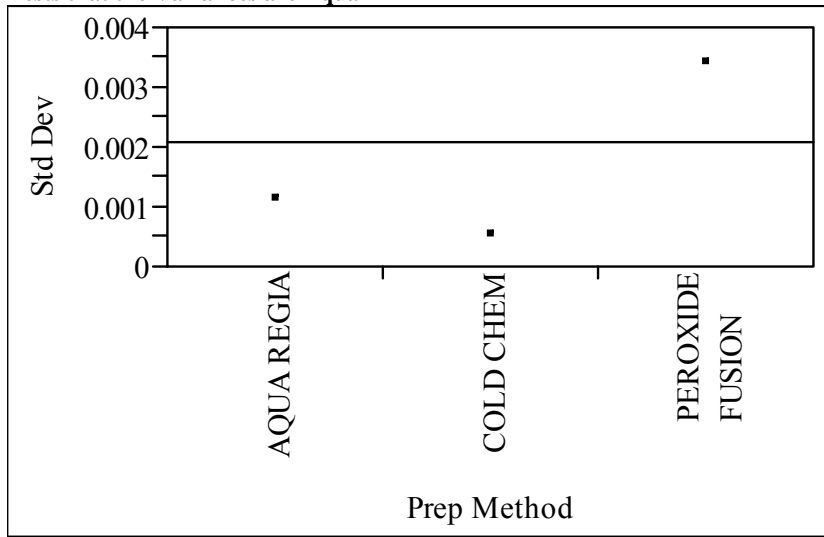

Level
AQUA REGIA

Count Std Dev MeanAbsDif to Mean MeanAbsDif to Median COLD CHEM

$\begin{array}{rrr}4 & 0.0011314 & 0.0008000 \\ 4 & 0.0005354 & 0.0003500 \\ 4 & 0.0034043 & 0.0024125\end{array}$

0.0008000

CHEM

40.0034043

0.0024125

0.0003500

Test F Ratio DFNum DFDen Prob $>$ F

$\begin{array}{lllll}\text { O'Brien[.5] } & 1.5078 & 2 & 9 & 0.2724 \\ \end{array}$

$\begin{array}{lllll}\text { Brown-Forsythe } & 1.6968 & 2 & 9 & 0.2370\end{array}$

$\begin{array}{lllll}\text { Levene } & 3.2229 & 2 & 9 & 0.0880 \\ \text { Bartlett } & 3.9027 & 2 & . & 0.0202\end{array}$

Warning: Small sample sizes. Use Caution.

Welch Anova testing Means Equal, allowing Std Devs Not Equal

F Ratio DFNum DFDen Prob > F

Means Comparisons

Comparisons for all pairs using Tukey-Kramer HSD

Level

PEROXIDE FUSION A $\quad 0.05667500$

AQUA REGIA $\quad$ B 0.05180000

Levels not connected by same letter are significantly different. 
Oneway Analysis of Measurement (Wt\%) By Prep Method Sample=SRAT Product, Element=Fe

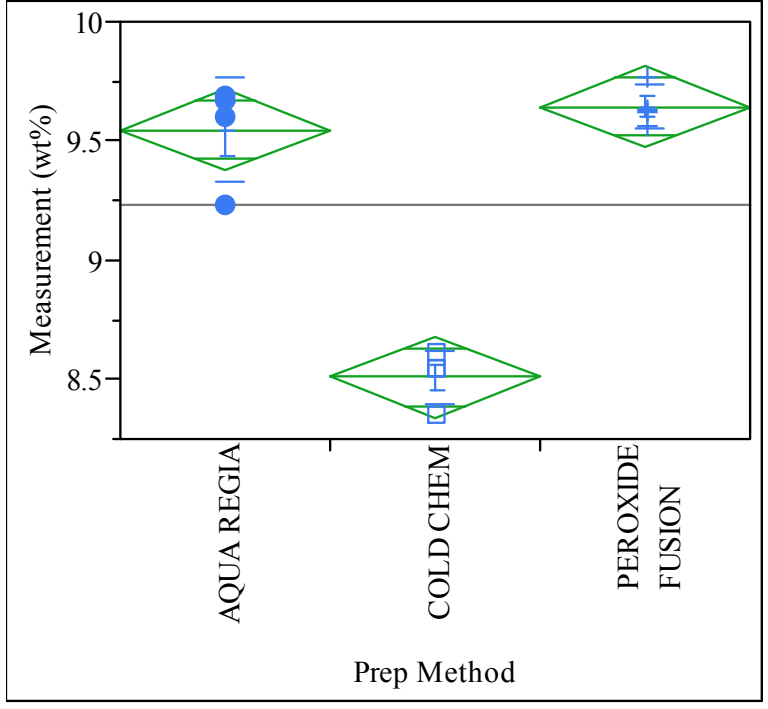

\section{Oneway Anova}

$\begin{array}{lr}\text { Rsquare } & 0.940581 \\ \text { Adj Rsquare } & 0.927376 \\ \text { Root Mean Square Error } & 0.149062 \\ \text { Mean of Response } & 9.234167 \\ \text { Observations (or Sum Wgts) } & 12\end{array}$

\section{Analysis of Variance}

Source DF Sum of Squares Mean Square F Ratio Prob $>$ F

$\begin{array}{lrrrr}\text { Prep Method } & 2 & 3.1655167 & 1.58276 & 71.2330<.0001\end{array}$

$\begin{array}{lrr}\text { Error } & 9 & 0.1999750 \\ \text { C. Total } & 11 & 3.3654917\end{array}$

\section{Means for Oneway Anova}

Level Number Mean Std Error Lower 95\% Upper 95\%

$\begin{array}{lllrr}\text { AQUA REGIA } & 49.54750 & 0.07453 & 9.3789 & 9.7161\end{array}$

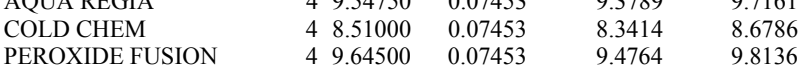

Std Error uses a pooled estimate of error variance

\section{Means and Std Deviations}

$\begin{array}{lrrrrrr}\text { Level } & \text { Number } & \text { Mean } & \text { Std Dev } & \text { Std Err Mean } & \text { Lower 95\% } & \text { Upper 95\% } \\ \text { AQUA REGIA } & 4 & 9.54750 & 0.215155 & 0.10758 & 9.2051 & 9.8899 \\ \text { COLD CHEM } & 4 & 8.51000 & 0.111654 & 0.05583 & 8.3323 & 8.6877 \\ \text { PEROXIDE FUSION } & 4 & 9.64500 & 0.088882 & 0.04444 & 9.5036 & 9.7864\end{array}$

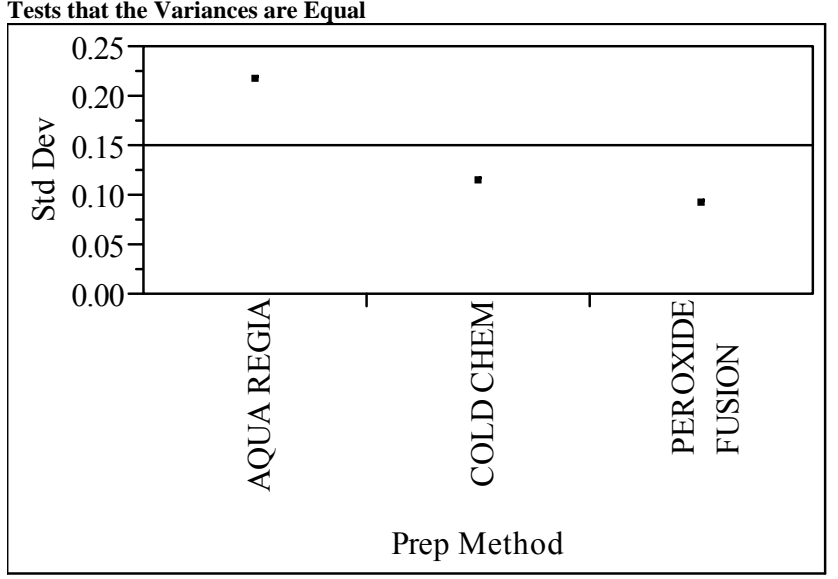

Level

Count Std Dev MeanAbsDif to Mean MeanAbsDif to Median

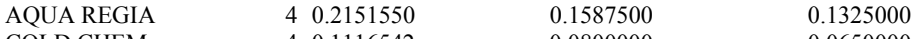

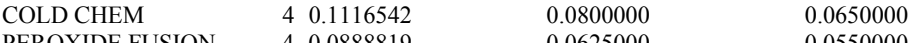
$\begin{array}{llll}\text { PEROXIDE FUSION } & 40.0888819 & 0.0625000 & 0.0550000\end{array}$

Test F Ratio DFNum DFDen Prob $>$ F

$\begin{array}{lllll}\text { O'Brien[.5] } & 0.8704 & 2 & 9 & 0.4513\end{array}$

$\begin{array}{lllll}\text { Brown-Forsythe } & 0.4684 & 2 & 9 & 0.6404\end{array}$

$\begin{array}{lllll}\text { Levene } & 1.6332 & 2 & 9 & 0.2482 \\ \text { Bartlett } & 1.1471 & 2 & . & 0.3176\end{array}$

Warning: Small sample sizes. Use Caution.

Welch Anova testing Means Equal, allowing Std Devs Not Equal

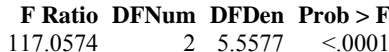

Means Comparisons

Comparisons for all pairs using Tukey-Kramer HSD

$\begin{array}{lr}\text { Level } & \text { Mean } \\ \text { PEROXIDE FUSION A } & 9.6450000\end{array}$

AQUA REGIA A 9.5475000

COLD CHEM $\quad$ B 8.5100000

Levels not connected by same letter are significantly different. 
Oneway Analysis of Measurement (Wt\%) By Prep Method Sample=SRAT Product, Element=K

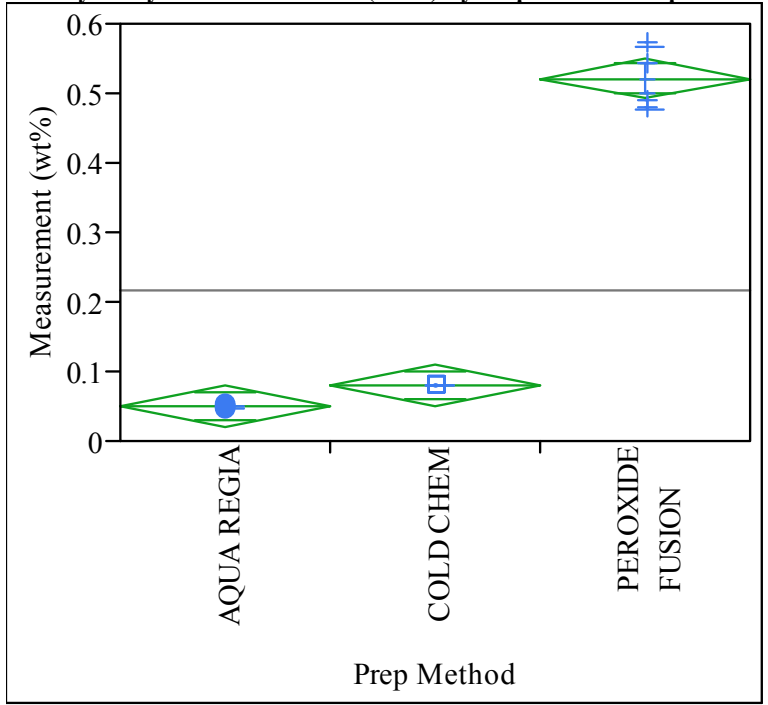

Oneway Anova

$\begin{array}{lr}\text { Rsquare } & 0.989448 \\ \text { Adj Rsquare } & 0.987104 \\ \text { Root Mean Square Error } & 0.025717 \\ \text { Mean of Response } & 0.217017 \\ \text { Observations (or Sum Wgts) } & 12\end{array}$

\section{Analysis of Variance}

Source DF Sum of Squares Mean Square F Ratio Prob $>$ F

$\begin{array}{lrrrrr}\text { Prep Method } & 2 & 0.55813945 & 0.279070 & 421.9769 & <.0001\end{array}$

$\begin{array}{lrrr}\text { Error } & 9 & 0.00595205 & 0.000661 \\ \text { C. Total } & 11 & 0.56409150 & \end{array}$

\section{Means for Oneway Anova}

Level Number Mean Std Error Lower 95\% Upper 95\%

$\begin{array}{llllll}\text { AQUA REGIA } & 4 & 0.049450 & 0.01286 & 0.02036 & 0.07854 \\ \text { COLD } & 4 & 0.080100 & 0.01286 & 0.05101 & 0.10919\end{array}$

$\begin{array}{llllll}\text { COLD CHEM } & 4 & 0.080100 & 0.01286 & 0.05101 & 0.10919 \\ \text { PEROXIDE FUSION } & 4 & 0.521500 & 0.01286 & 0.49241 & 0.55059\end{array}$

Std Error uses a pooled estimate of error variance

\section{Means and Std Deviations}

$\begin{array}{lrrrrrr}\text { Level } & \text { Number } & \text { Mean } & \text { Std Dev } & \text { Std Err Mean } & \text { Lower 95\% } & \text { Upper 95\% } \\ \text { AQUA REGIA } & 4 & 0.049450 & 0.001905 & 0.00095 & 0.04642 & 0.05248 \\ \text { COLD CHEM } & 4 & 0.080100 & 0.001178 & 0.00059 & 0.07823 & 0.08197 \\ \text { PEROXIDE FUSION } & 4 & 0.521500 & 0.044486 & 0.02224 & 0.45071 & 0.59229\end{array}$

Tests that the Variances are Equal

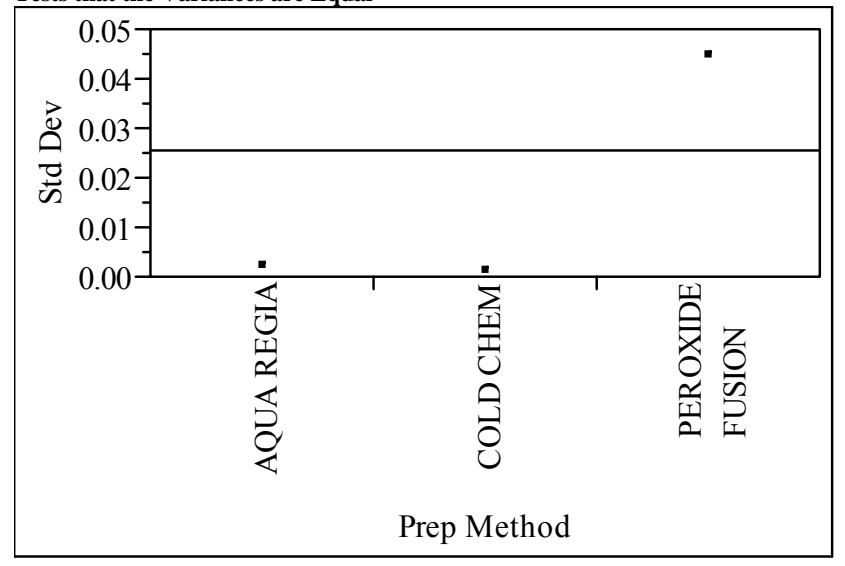

Level

Count Std Dev MeanAbsDif to Mean MeanAbsDif to Median

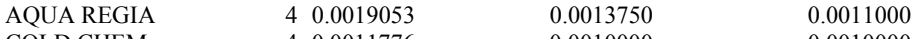

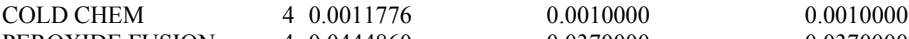

$\begin{array}{llll}\text { PEROXIDE FUSION } & 4 & 0.0444860 & 0.0370000\end{array}$

Test F Ratio DFNum DFDen Prob $>$ F

$\begin{array}{lllll}\text { O'Brien[.5] } & 6.5908 & 2 & 9 & 0.0173\end{array}$

$\begin{array}{lllll}\text { Brown-Forsythe } & 27.2843 & 2 & 9 & 0.0002 \\ \text { Levene } & 33.1369 & 2 & 9 & <.0001\end{array}$

$\begin{array}{llll}\text { Bartlett } & 13.4255 & 2 & <\end{array}$

Warning: Small sample sizes. Use Caution.

Welch Anova testing Means Equal, allowing Std Devs Not Equal

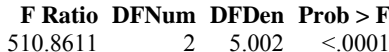

Means Comparisons

Comparisons for all pairs using Tukey-Kramer HSD

Level

PEROXIDE FUSION A $\quad \begin{array}{r}\text { Mean } \\ 0.52150000\end{array}$

$\begin{array}{ll}\text { COLD CHEM } & \text { B } 0.08010000\end{array}$

AQUA REGIA $\quad$ B 0.04945000

Levels not connected by same letter are significantly different. 
Oneway Analysis of Measurement (Wt\%) By Prep Method Sample=SRAT Product, Element=Li

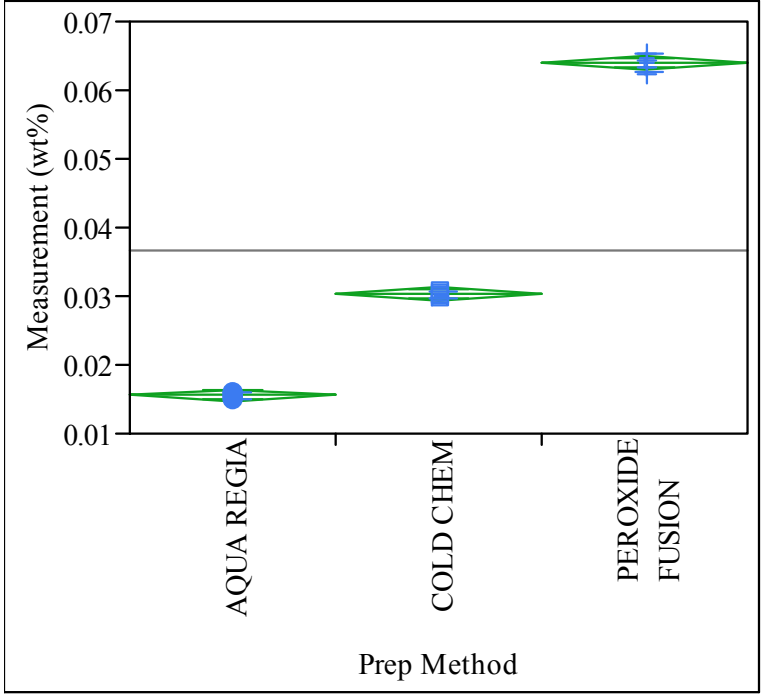

Oneway Anova

$\begin{array}{lr}\text { Rsquare } & 0.998662 \\ \text { Adj Rsquare } & 0.998365 \\ \text { Root Mean Square Error } & 0.000855 \\ \text { Mean of Response } & 0.036542 \\ \text { Observations (or Sum Wgts) } & 12\end{array}$

Analysis of Variance

Source DF Sum of Squares Mean Square F Ratio Prob $>$ F

$\begin{array}{lllllll}\text { Prep Method } & 2 & 0.00491485 & 0.002457 & 3359.941 & <.0001\end{array}$

$\begin{array}{lrrr}\text { Error } & 9 & 0.00000658 & 7.314 \mathrm{e}-7 \\ \text { C. Total } & 11 & 0.00492143\end{array}$

Means for Oneway Anova

$\begin{array}{lrrrrr}\text { Level } & \text { Number } & \text { Mean } & \text { Std Error } & \text { Lower 95\% } & \text { Upper 95\% } \\ \text { AQUA REGIA } & 4 & 0.015525 & 0.00043 & 0.01456 & 0.01649 \\ \text { COLD CHEM } & 4 & 0.030225 & 0.00043 & 0.02926 & 0.03119 \\ \text { PEROXIDE FUSION } & 4 & 0.063875 & 0.00043 & 0.06291 & 0.06484\end{array}$

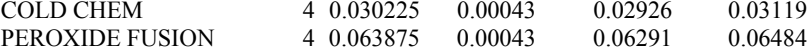

Std Error uses a pooled estimate of error variance

Means and Std Deviations

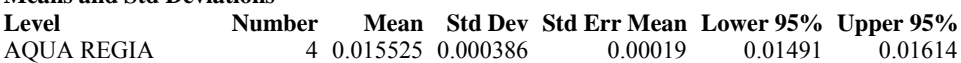

$\begin{array}{lllllll}\text { AQUA REGIA } & 4 & 0.015525 & 0.000386 & 0.00019 & 0.01491 & 0.01614 \\ \text { COLD CHEM } & 4 & 0.030225 & 0.000443 & 0.00022 & 0.02952 & 0.03093\end{array}$

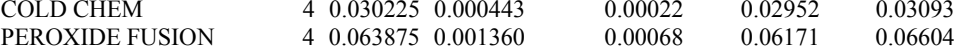

Tests that the Variances are Equal

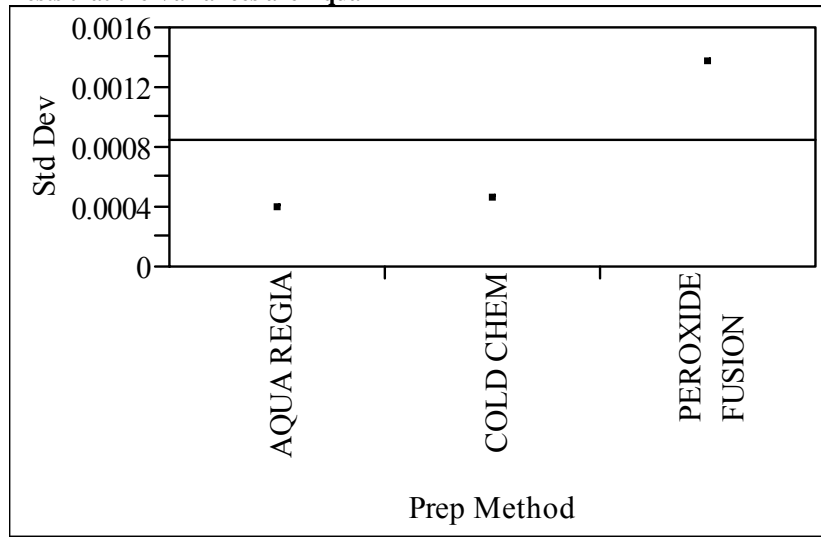

Level

Count Std Dev MeanAbsDif to Mean MeanAbsDif to Median

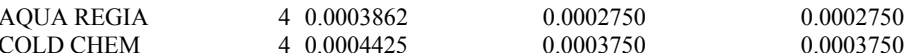

PEROXIDE FUSION $\quad 40.0043598$

Test F Ratio DFNum DFDen Prob $>F$

$\begin{array}{lllll}\text { O'Brien[.5] } & 2.7890 & 2 & 9 & 0.1141\end{array}$

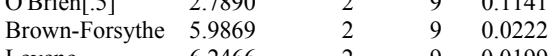

$\begin{array}{lllll}\text { Brown-Forsythe } & 5.9869 & 2 & 9 & 0.0222 \\ \text { Levene } & 6.2466 & 2 & 9 & 0.0199 \\ \text { Bartlett } & 2.5868 & 2 & & 0.0753\end{array}$

Warning: Small sample sizes. Use Caution.

Welch Anova testing Means Equal, allowing Std Devs Not Equal

F Ratio DFNum DFDen Prob $>$ F

$2741.3132<5.4516<0001$

Means Comparisons

Comparisons for all pairs using Tukey-Kramer HSD

Level

Mean
PEROXIDE FUSION A $\quad 0.06387500$

$\begin{array}{lll}\text { COLD CHEM } & 0.06387500 \\ \text { A } & 0.03022500\end{array}$

Levels not connected by same letter are significantly different. 
Oneway Analysis of Measurement (Wt\%) By Prep Method Sample=SRAT Product, Element=Mg

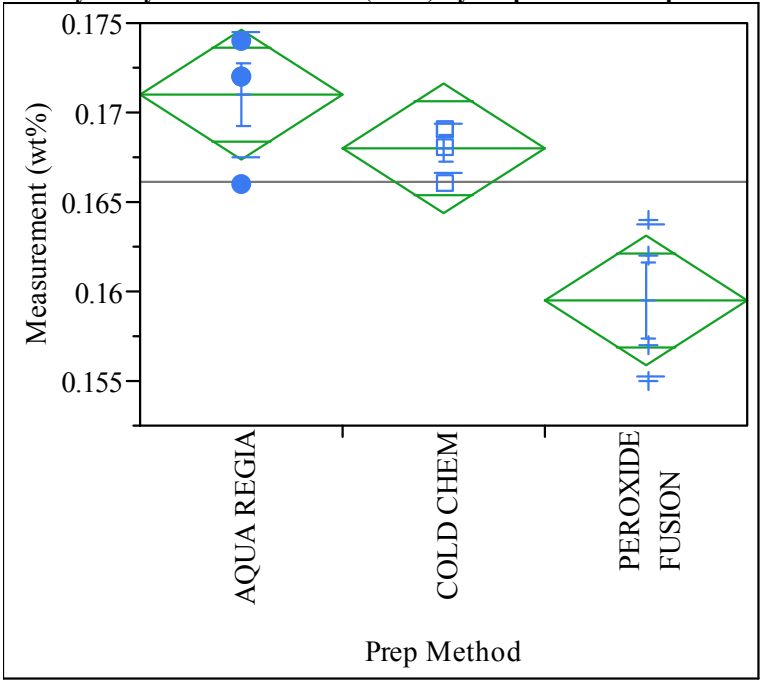

Oneway Anova

Summary of Fit

$\begin{array}{lr}\text { Rsquare } & 0.749781 \\ \text { Adj Rsquare } & 0.694176 \\ \text { Root Mean Square Error } & 0.003249 \\ \text { Mean of Response } & 0.166167 \\ \text { Observations (or Sum Wgts) } & 12\end{array}$

Analysis of Variance

Source DF Sum of Squares Mean Square F Ratio Prob > F

$\begin{array}{lrrrrr}\text { Source } & \text { DF } & \text { Sum of Squares } & \text { Mean Square } & \text { F Ratio } & \text { Prob }>\text { F } \\ \text { Prep Method } & 2 & 0.00028467 & 0.000142 & 13.4842 & 0.0020\end{array}$

$\begin{array}{llll}\text { Prep Method } & 2 & 0.00028467 & 0.000142 \\ \text { Error } & 9 & 0.00009500 & 0.000011\end{array}$

$\begin{array}{lrr}\text { C. Total } & 11 & 0.00037967\end{array}$

Means for Oneway Anova

Level Number Mean Std Error Lower 95\% Upper 95\%

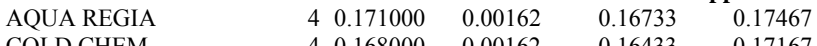

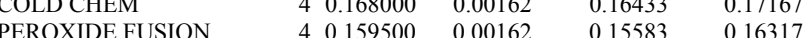

Std Error uses a pooled estimate of error variance

Means and Std Deviations

Level Number Mean Std Dev Std Err Mean Lower 95\% Upper 95\%

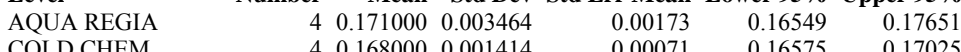

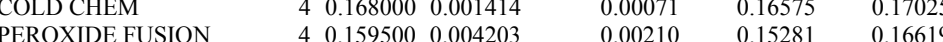

Tests that the Variances are Equal

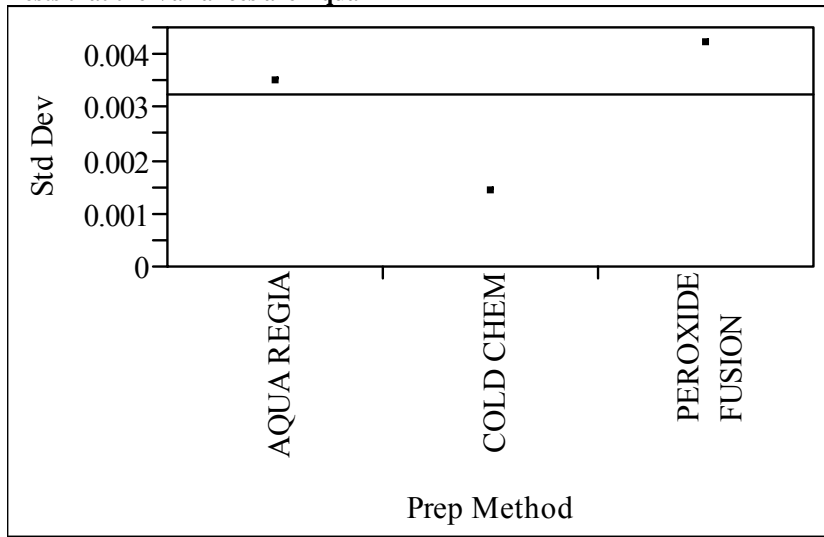

Level
AQUA REGIA

Count Std Dev MeanAbsDif to Mean MeanAbsDif to Median

COLD CHEM

$\begin{array}{lll}4 & 0.0034641 & 0.0025000 \\ 4 & 0.0014142 & 0.0010000\end{array}$

0.0035000

0.0020000

TEM

$\begin{array}{ll}4 & 0.0014142 \\ 4 & 0.0042032\end{array}$

.0010000

Test F Ratio DFNum DFDen Prob $>$ F

$\begin{array}{lllll}\text { O'Brien[.5] } & 1.3846 & 2 & 9 & 0.2990 \\ \text { B } & 1.8387 & 2 & 9 & 0.2140\end{array}$

$\begin{array}{lllll}\text { Brown-Forsythe } & 1.8387 & 2 & 9 & 0.2140 \\ \text { Levene } & 3.3529 & 2 & 9 & 0.0816\end{array}$

$\begin{array}{lllll}\text { Bartlett } & 1.3329 & 2 & 9 & 0.0816 \\ & & & & 0.2637\end{array}$

Warning: Small sample sizes. Use Caution.

Welch Anova testing Means Equal, allowing Std Devs Not Equal

\section{F Ratio DFNum DFDen Prob > F}

\section{Means Comparisons}

Comparisons for all pairs using Tukey-Kramer HSD

$\begin{array}{lrr}\text { Level } & & \text { Mean } \\ \text { AQUA REGIA } & \text { A } & 0.17100000 \\ \text { COLD CHEM } & \text { A } & 0.16800000 \\ \text { PEROXIDE FUSION } & \text { B } & 0.15950000\end{array}$

Levels not connected by same letter are significantly different. 
Oneway Analysis of Measurement (Wt\%) By Prep Method Sample=SRAT Product, Element=Mn

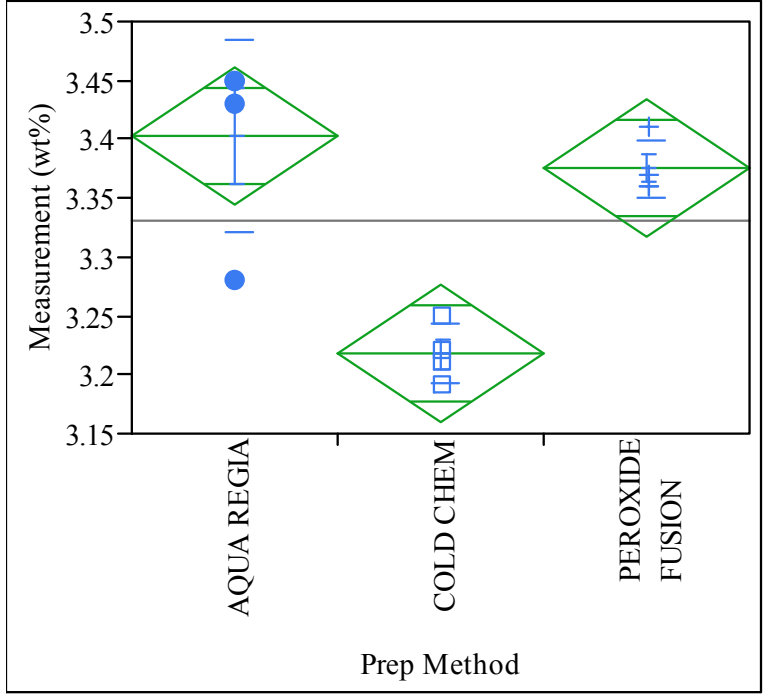

Oneway Anova

Summary of Fit

$\begin{array}{lr}\text { Rsquare } & 0.769714 \\ \text { Adj Rsquare } & 0.718539 \\ \text { Root Mean Square Error } & 0.051478 \\ \text { Mean of Response } & 3.331667 \\ \text { Observations (or Sum Wgts) } & 12\end{array}$

Analysis of Variance

Source DF Sum of Squares Mean Square F Ratio Prob $>$ F

$\begin{array}{lllllll}\text { Prep Method } & 2 & 0.07971667 & 0.039858 & 15.0409 & 0.0013\end{array}$

$\begin{array}{lrrr}\text { Error } & 9 & 0.02385000 & 0.002650 \\ \text { C. Total } & 11 & 0.10356667 & \end{array}$

Means for Oneway Anova

Level $\quad$ Number $\quad$ Mean Std Error Lower 95\% Upper 95\%

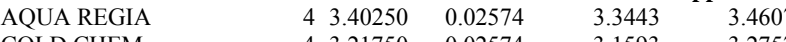

$\begin{array}{lllll}\text { COLD CHEM } & 43.21750 & 0.02574 & 3.1593 & 3.2757\end{array}$

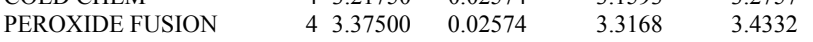

Std Error uses a pooled estimate of error variance

\section{Means and Std Deviations}

$\begin{array}{lrrrrrr}\text { Means and Std Deviations } & \text { Number } & \text { Mean } & \text { Std Dev } & \text { Std Err Mean } & \text { Lower 95\% } & \text { Upper 95\% } \\ \text { Level } & 4 & 3.40250 & 0.082209 & 0.04110 & 3.2717 & 3.5333 \\ \text { AQUA REGIA } & 4 & 3.21750 & 0.025000 & 0.01250 & 3.1777 & 3.2573 \\ \text { COLD CHEM } & 4 & 3.37500 & 0.023805 & 0.01190 & 3.3371 & 3.4129\end{array}$

Tests that the Variances are Equal

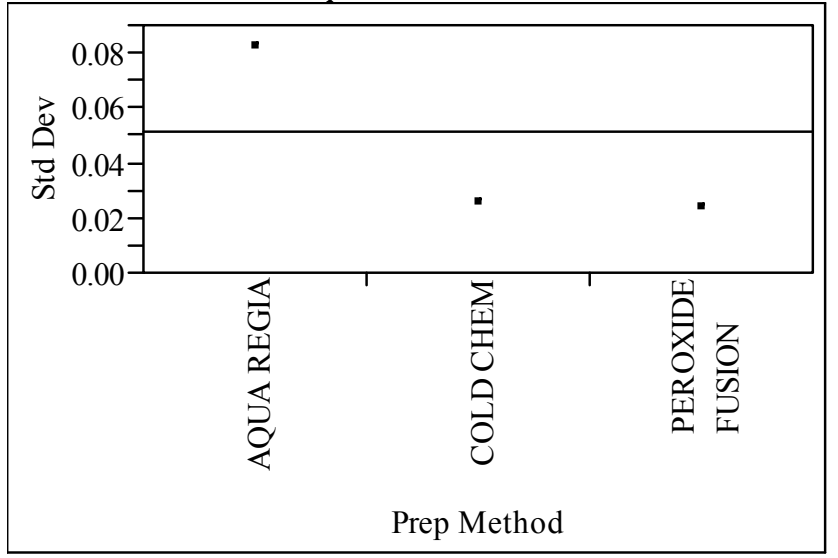

Leve

Count Std Dev MeanAbsDif to Mean MeanAbsDif to Median

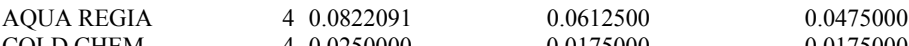

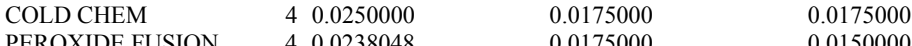

$\begin{array}{llll}\text { PEROXIDE FUSION } & 4 & 0.0238048 & 0.0175000\end{array}$

Test F Ratio DFNum DFDen Prob $>$ F

$\begin{array}{lllll}\text { O'Brien[.5] } & 1.2166 & 2 & 9 & 0.3407\end{array}$

$\begin{array}{lllll}\text { Brown-Forsythe } & 0.6280 & 2 & 9 & 0.5555 \\ \text { Levene } & 3.5924 & 2 & 9 & 0.0713 \\ \text { Beve } & 2.6794 & 2 & & 0.0686\end{array}$

$\begin{array}{lllll}\text { Bartlett } & 2.6794 & 2 & . & 0.0686\end{array}$

Warning: Small sample sizes. Use Caution.

Welch Anova testing Means Equal, allowing Std Devs Not Equal

F Ratio DFNum DFDen Prob $>$ F

$\begin{array}{lrrr}39.7618 & 2 & 5.4733 & 0.0005\end{array}$

Means Comparisons

Comparisons for all pairs using Tukey-Kramer HSD

Level

AQUA REGIA A Mean

PEROXIDE FUSION A 3.3750000

$\begin{array}{lll}\text { COLD CHEM } & \text { B } 3.2175000\end{array}$

Levels not connected by same letter are significantly different. 
Oneway Analysis of Measurement (Wt\%) By Prep Method Sample=SRAT Product, Element=Na

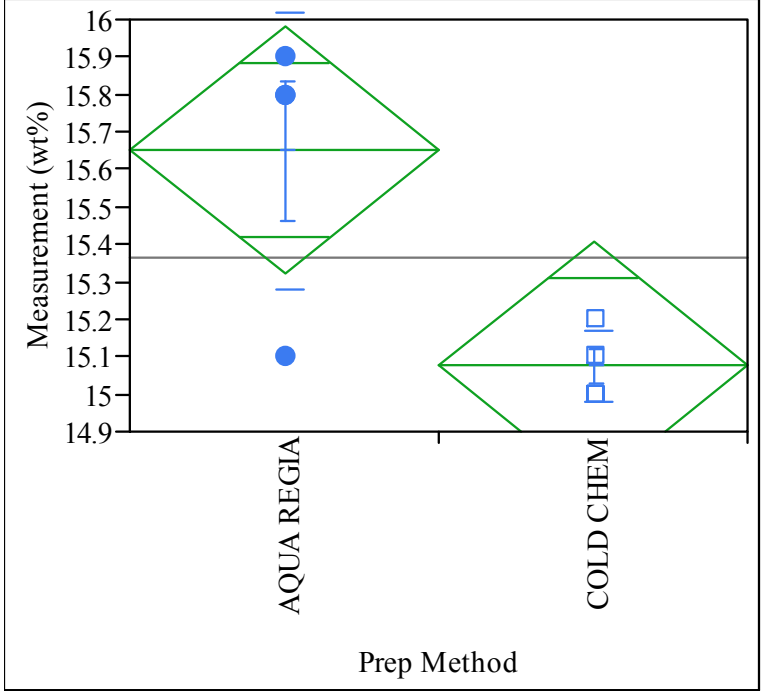

Missing Rows

4

Oneway Anova

$\begin{array}{lr}\text { Rsquare } & 0.60182 \\ \text { Adj Rsquare } & 0.535457 \\ \text { Root Mean Square Error } & 0.270031 \\ \text { Mean of Response } & 15.3625 \\ \text { Observations (or Sum Wgts) } & 8\end{array}$

\section{Analysis of Variance}

Source DF Sum of Squares Mean Square F Ratio Prob > F

$\begin{array}{llllll}\text { Prep Method } & 1 & 0.6612500 & 0.661250 & 9.0686 & 0.0237\end{array}$

$\begin{array}{lll}\text { Error } & 6 & 0.4375000 \\ \text { C. Total } & 7 & 1.0987500\end{array}$

Means for Oneway Anova

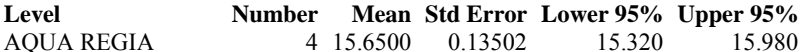

$\begin{array}{llllll}\text { AQUA REGIA } & 4 & 15.6500 & 0.13502 & 15.320 & 15.980 \\ \text { COLD CHEM } & 4 & 15.0750 & 0.13502 & 14.745 & 15.405 \\ \text { PEROXIDE FUSION } & 0 & . & & & \end{array}$

PEROXIDE FUSION

Std Error uses a pooled estimate of error variance

\section{Means and Std Deviations}

$\begin{array}{lrrrrrr}\text { Level } & \text { Number } & \text { Mean } & \text { Std Dev } & \text { Std Err Mean } & \text { Lower 95\% } & \text { Upper 95\% } \\ \text { AQUA REGIA } & 4 & 15.6500 & 0.369685 & 0.18484 & 15.062 & 16.238 \\ \text { COLD CHEM } & 4 & 15.0750 & 0.095743 & 0.04787 & 14.923 & 15.227 \\ \text { PEROXIDE FUSION } & 0 & . & . & & . & \end{array}$

Tests that the Variances are Equal

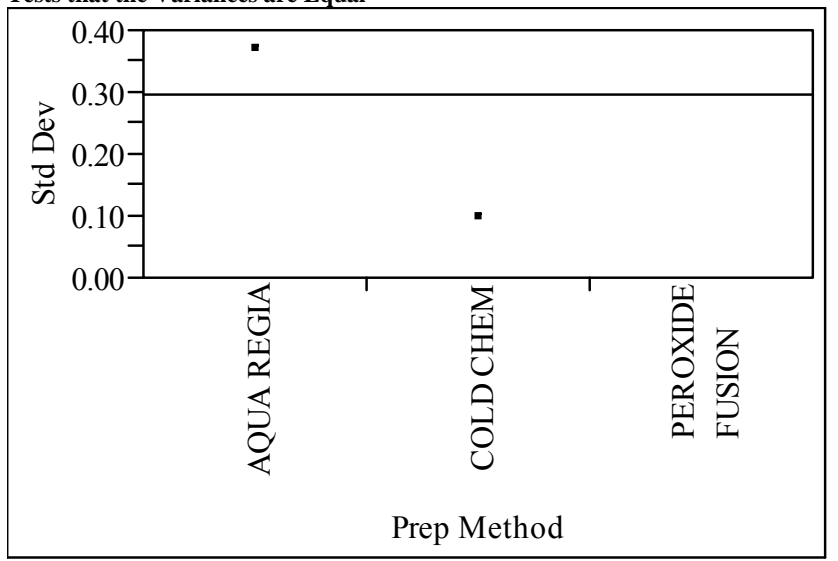

Level

COLD CHEM

Count Std Dev MeanAbsDif to Mean MeanAbsDif to Median $\begin{array}{ll}0.3696846 & 0.2750000 \\ 0.0957427 & 0.0750000\end{array}$

Test F Ratio DFNum DFDen Prob $>$ F

$\begin{array}{lllll}\text { O'Brien[.5] } & 1.2881 & 1 & 6 & 0.2997\end{array}$

$\begin{array}{lllll}\text { Brown-Forsythe } & 0.5396 & 1 & 6 & 0.4903\end{array}$

$\begin{array}{lllll}\text { Levene } & 4.2667 & 1 & 6 & 0.0844\end{array}$

$\begin{array}{lllll}\text { Bartlett } & 3.7170 & 1 & 0.0539\end{array}$

Warning: Small sample sizes. Use Caution.

Welch Anova testing Means Equal, allowing Std Devs Not Equal

F Ratio DFNum DFDen Prob > F

$\begin{array}{rrrr}9.0686 & 1 & 3.4006 & 0.0487\end{array}$ 
Oneway Analysis of Measurement (Wt\%) By Prep Method Sample=SRAT Product, Element=Ni

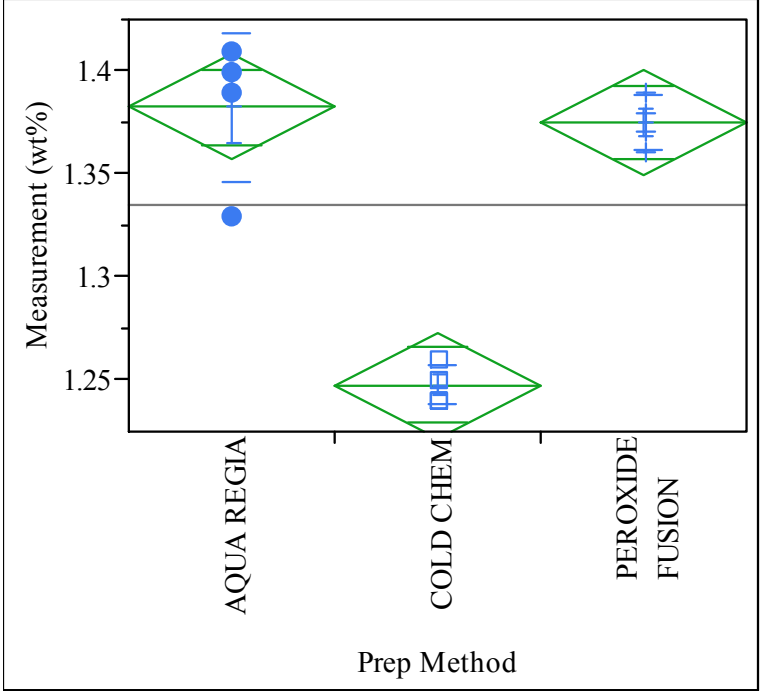

Oneway Anova

\section{Adj Rsquare \\ 0.908284 \\ Root Mean Square Error $\quad 0.887903$ \\ $\begin{array}{lr}\text { Mean of Response } & 1.335 \\ \text { Observations (or Sum Wgts) } & 12\end{array}$}

Analysis of Variance

Source DF Sum of Squares Mean Square F Ratio Prob $>$ F

$\begin{array}{lllllll}\text { Prep Method } & 2 & 0.04605000 & 0.023025 & 44.5645 & <.0001\end{array}$

0.00465000

0.000517

Means for Oneway Anova

$\begin{array}{lrrrrr}\text { Level } & \text { Number } & \text { Mean } & \text { Std Error } & \text { Lower 95\% } & \text { Upper 95\% } \\ \text { AQUA REGIA } & 4 & 1.38250 & 0.01137 & 1.3568 & 1.4082 \\ \text { COLD CHEM } & 4 & 1.24750 & 0.01137 & 1.2218 & 1.2732 \\ \text { PEROXIDE FUSION } & 4 & 1.37500 & 0.01137 & 1.3493 & 1.4007\end{array}$

$\begin{array}{llllll}\text { PEROXIDE FUSION } & 4 & 1.24750 & 0.01137 & 1.2218 & 1.2732 \\ & 4 & 1.37500 & 0.01137 & 1.3493 & 1.4007\end{array}$

Std Error uses a pooled estimate of error variance

\section{Means and Std Deviations}

$\begin{array}{lrrrrrr}\text { Means and Std Deviations } & \text { Number } & \text { Mean } & \text { Std Dev } & \text { Std Err Mean } & \text { Lower 95\% } & \text { Upper 95\% } \\ \text { Level } & 4 & 1.38250 & 0.035940 & 0.01797 & 1.3253 & 1.4397 \\ \text { AQUA REGIA } & 4 & 1.24750 & 0.009574 & 0.00479 & 1.2323 & 1.2627 \\ \text { COLD CHEM } & 4 & 1.37500 & 0.012910 & 0.00645 & 1.3545 & 1.3955\end{array}$

Tests that the Variances are Equal

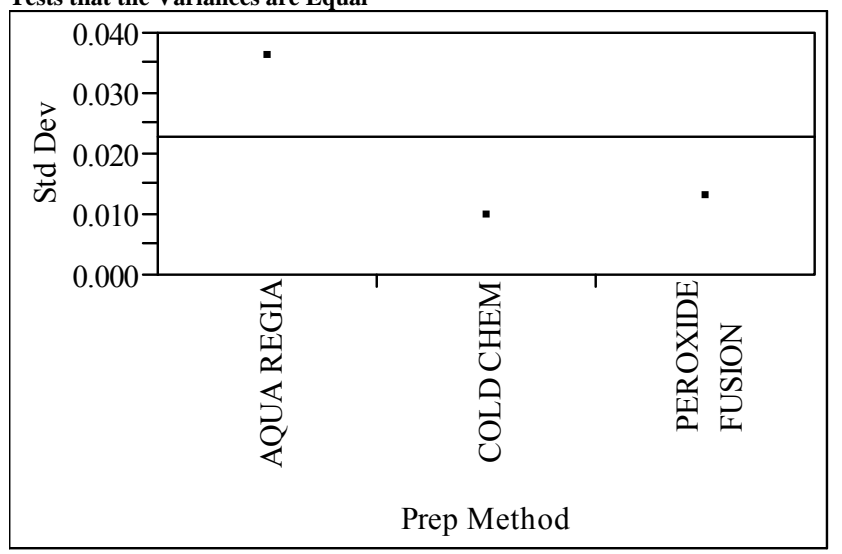

$\begin{array}{lrrrr}\text { Level } & \text { Count } & \text { Std Dev } & \text { MeanAbsDif to Mean } & \text { MeanAbsDif to Median } \\ \text { AQUA REGIA } & 4 & 0.0359398 & 0.0262500 & 0.0225000 \\ \text { COLD CHEM } & 4 & 0.0095743 & 0.0075000 & 0.0075000\end{array}$

Count Std Dev MeanAbsDif to Mean MeanAbsDif to Median

COROXIDE FUSION $\quad 40.0129099-0.0100000-0.0100000$

Test F Ratio DFNum DFDen Prob > F

$\begin{array}{lllll}\text { O'Brien[.5] } & 1.2832 & 2 & 9 & 0.3234 \\ & 0.8774 & 2 & 9 & 0.4486\end{array}$

$\begin{array}{lllll}\text { Brown-Forsythe } & 0.8774 & 2 & 9 & 0.4486 \\ \text { Levene } & 2.9409 & 2 & 9 & 0.1040\end{array}$

$\begin{array}{lllll}\text { Bartlett } & 2.5402 & 2 & . & 0.0789\end{array}$

Warning: Small sample sizes. Use Caution.

Welch Anova testing Means Equal, allowing Std Devs Not Equal

\section{F Ratio DFNum DFDen Prob $>$ F}

$\begin{array}{lllll}122.4956 & 2 & 5.3418 & <.0001\end{array}$

Means Comparisons

Comparisons for all pairs using Tukey-Kramer HSD

$\begin{array}{lrr}\text { Level } & & \text { Mean } \\ \text { AQUA REGIA } & \text { A } & 1.3825000 \\ \text { PEROXIDE FUSION } & \text { A } & 1.3750000 \\ \text { COLD CHEM } & \text { B } & 1.2475000\end{array}$

COLD CHEM B 1.2475000

Levels not connected by same letter are significantly different. 
Oneway Analysis of Measurement (Wt\%) By Prep Method Sample=SRAT Product, Element=Si

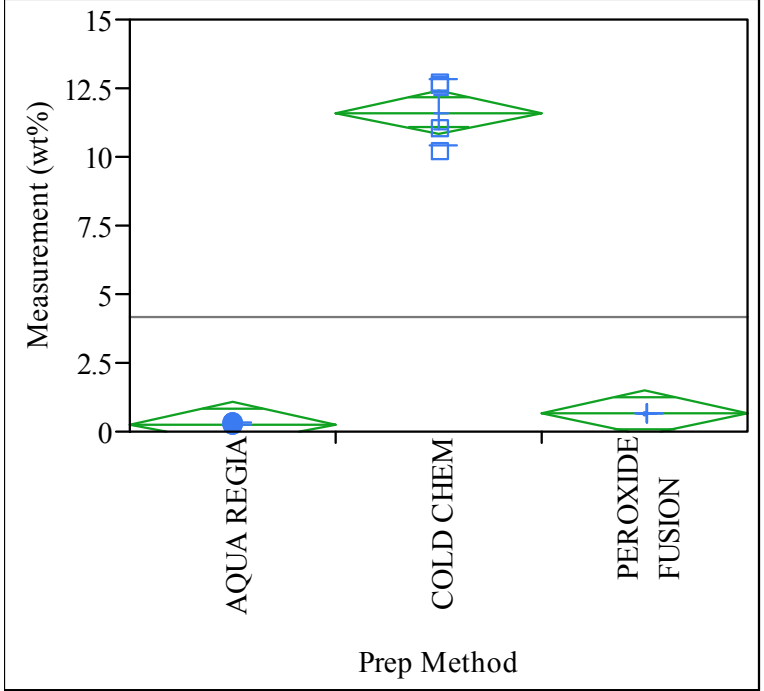

Oneway Anova

Summary of Fit

$\begin{array}{lr}\text { Rsquare } & 0.986493 \\ \text { Adj Rsquare } & 0.983491 \\ \text { Root Mean Square Error } & 0.710487 \\ \text { Mean of Response } & 4.192 \\ \text { Observations (or Sum Wgts) } & 12\end{array}$

Analysis of Variance

Source DF Sum of Squares Mean Square F Ratio Prob $>$ F

$\begin{array}{llllll}\text { Prep Method } & 2 & 331.80662 & 165.903 & 328.6567 & <.0001\end{array}$

$\begin{array}{lrrr}\text { Error } & 9 & 4.54313 & 0.505\end{array}$

Means for Oneway Anova

Level $\quad$ Number $\quad$ Mean Std Error Lower 95\% Upper 95\%

$\begin{array}{llllll}\text { AQUA REGIA } & 4 & 0.2788 & 0.35524 & -0.52 & 1.082\end{array}$

$\begin{array}{lrrrrr}\text { COLD CHEM } & 4 & 11.6250 & 0.35524 & 10.82 & 12.429 \\ \text { PEROXIDE FUSION } & 4 & 0.6723 & 0.35524 & -0.13 & 1.476\end{array}$

PEROXIDE FUSION

$-0.13 \quad 1.47$

Std Error uses a pooled estimate of error variance

\section{Means and Std Deviations}

$\begin{array}{lrrrrrr}\text { Level } & \text { Number } & \text { Mean } & \text { Std Dev } & \text { Std Err Mean } & \text { Lower 95\% } & \text { Upper 95\% } \\ \text { AQUA REGIA } & 4 & 0.2788 & 0.06804 & 0.03402 & 0.1705 & 0.387\end{array}$

$\begin{array}{llrrrrr} & 4 & 0.2788 & 0.06804 & 0.03402 & 0.1705 & 0.387 \\ \text { COLD CHEM } & 4 & 11.6250 & 1.22848 & 0.61424 & 9.6702 & 13.580\end{array}$

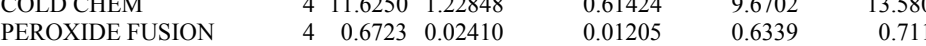

Tests that the Variances are Equal

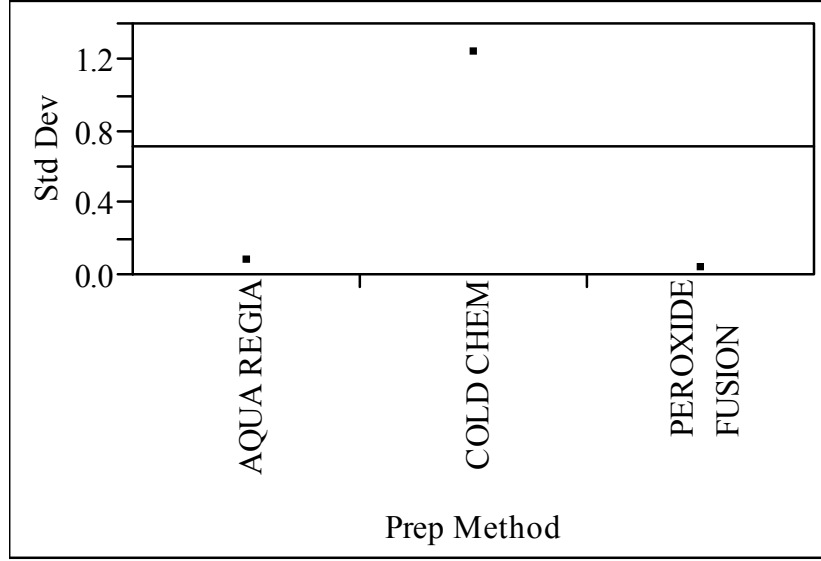

Leve

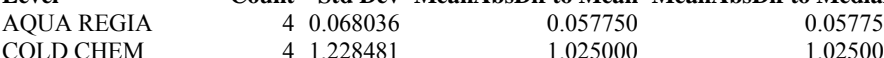

Mean MeanAbsDif to Median

$\begin{array}{lllll} & 4 & 1.228481 & 1.025000 & 1.025000 \\ \text { PEROXIDE FUSION } & 4 & 0.024102 & 0.016750 & 0.016750\end{array}$

Test F Ratio DFNum DFDen Prob $>$ F

$\begin{array}{lllll}\text { O'Brien[.5] } & 7.0510 & 2 & 9 & 0.0144\end{array}$

Brown-Forsythe $26.1132 \quad 2 \quad 390.00002$

$\begin{array}{lllll}\text { Levene } & 35.9415 & 2 & 9 & <.0001 \\ \text { Bartlett } & 13.5400 & 2 & & <.0001\end{array}$

Warning: Small sample sizes. Use Caution.

Welch Anova testing Means Equal, allowing Std Devs Not Equal

F Ratio DFNum DFDen Prob $>$ F

$190.9754 \quad 2 \quad 4.4412<0001$

\section{Means Comparisons}

Comparisons for all pairs using Tukey-Kramer HSD

$\begin{array}{lrr}\text { Level } & & \text { Mean } \\ \text { COLD CHEM } & \text { A } & 11.625000 \\ \text { PEROXIDE FUSION } & \text { B } & 0.672250 \\ \text { AQUA REGIA } & \text { B } & 0.278750\end{array}$

Levels not connected by same letter are significantly different. 
Oneway Analysis of Measurement (Wt\%) By Prep Method Sample=SRAT Product, Element=Ti

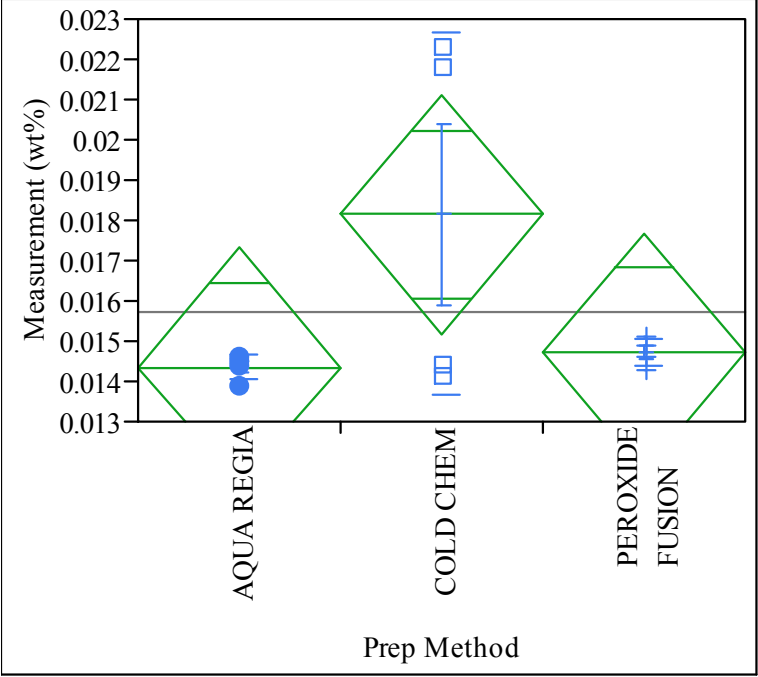

Oneway Anova

Summary of Fit

$\begin{array}{lr}\text { Rsquare } & 0.362604 \\ \text { Adj Rsquare } & 0.220961 \\ \text { Root Mean Square Error } & 0.002618 \\ \text { Mean of Response } & 0.015742 \\ \text { Observations (or Sum Wgts) } & 12\end{array}$

Analysis of Variance

Source DF Sum of Squares Mean Square F Ratio Prob $>$ F

$\begin{array}{lrrrrr}\text { Source } & \text { DF } & \text { Sum of Squares } & \text { Mean Square } & \text { F Ratio } & \text { Prob }>\text { F } \\ \text { Prep Method } & 2 & 0.00003508 & 0.000018 & 2.5600 & 0.1318\end{array}$

$\begin{array}{lll}\text { Erep Method } & 2 & 0.00003508 \\ \text { Error } & 9 & 0.00006167\end{array}$

$6.852 \mathrm{e}-6$

$\begin{array}{lll}\text { C. Total } & 11 & 0.00009675\end{array}$

Means for Oneway Anova

Level Number Mean Std Error Lower 95\% Upper 95\%

$\begin{array}{llllll}\text { AQUA REGIA } & 4 & 0.014350 & 0.00131 & 0.01139 & 0.01731\end{array}$

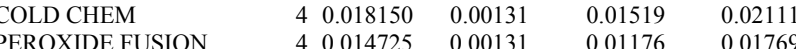

Std Error uses a pooled estimate of error variance

$\begin{array}{lrrrrrr}\text { Means and Std Deviations } & & & & & & \\ \text { Level } & \text { Number } & \text { Mean } & \text { Std Dev } & \text { Std Err Mean } & \text { Lower 95\% } & \text { Upper 95\% } \\ \text { AQUA REGIA } & 4 & 0.014350 & 0.000311 & 0.00016 & 0.01386 & 0.01484 \\ \text { COLD CHEM } & 4 & 0.018150 & 0.004510 & 0.00225 & 0.01097 & 0.02533 \\ \text { PEROXIDE FUSION } & 4 & 0.014725 & 0.000350 & 0.00018 & 0.01417 & 0.01528\end{array}$

Tests that the Variances are Equal

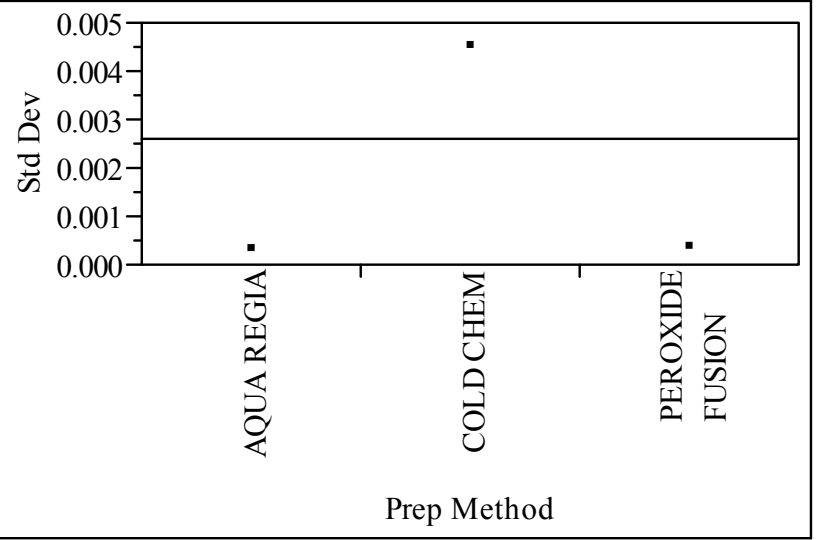

Level Count Std Dev MeanAbsDif to Mean MeanAbsDif to Median

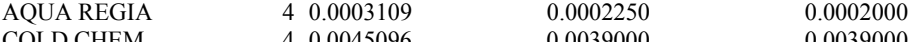

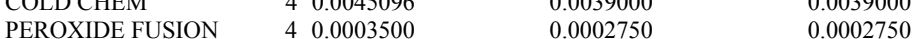

Test F Ratio DFNum DFDen Prob $>$ F

$\begin{array}{lllll}\text { O'Brien[.5] } & 170.1347 & 2 & 9 & <.0001 \\ & & \end{array}$

Brown-Forsythe $385.6707 \quad 2 \quad 2004$

$\begin{array}{lrrrr}\text { Bartlett } & 9.4029 & 2 & <.0001\end{array}$

Warning: Small sample sizes. Use Caution.

Welch Anova testing Means Equal, allowing Std Devs Not Equal

F Ratio DFNum DFDen Prob $>$ F

$\begin{array}{llll}2.2917 & 2 & 5.3182 & 0.1915\end{array}$

Means Comparisons

Comparisons for all pairs using Tukey-Kramer HSD

Level Mean

PEROXIDE FUSION A 0.01472500

AQUA REGIA A 0.01435000

Levels not connected by same letter are significantly different. 
Oneway Analysis of Measurement (Wt\%) By Prep Method Sample=SRAT Product, Element=Zr

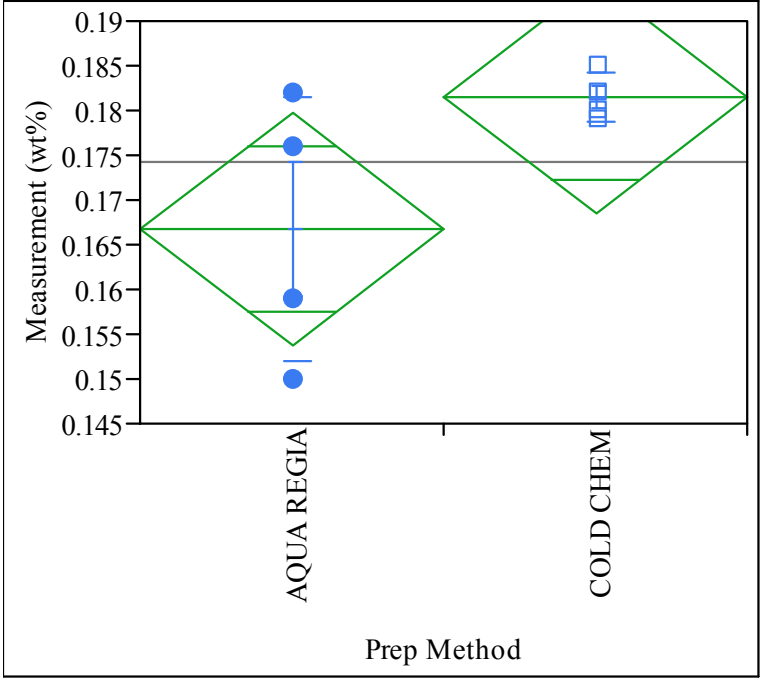

Missing Rows

Oneway Anova

Summary of Fit

$\begin{array}{lr}\text { Rsquare } & 0.39029 \\ \text { Adj Rsquare } & 0.288672 \\ \text { Root Mean Square Error } & 0.010644 \\ \text { Mean of Response } & 0.174125 \\ \text { Observations (or Sum Wgts) } & 8\end{array}$

Analysis of Variance

Source DF Sum of Squares Mean Square F Ratio Prob > F

$\begin{array}{lrrrrr}\text { Source } & \text { DF } & \text { Sum of Squares } & \text { Mean Square } & \text { F Ratio } & \text { Prob }>\text { F } \\ \text { Prep Method } & 1 & 0.00043512 & 0.000435 & 3.8408 & 0.0977 \\ \text { Error } & 6 & 0.00067975 & 0.000113 & & \end{array}$

$\begin{array}{lll}\text { C. Total } & 7 & 0.00111488\end{array}$

Means for Oneway Anova

$\begin{array}{lrrrrr}\text { Level } & \text { Number } & \text { Mean } & \text { Std Error } & \text { Lower 95\% } & \text { Upper 95\% } \\ \text { AQUA REGIA } & 4 & 0.166750 & 0.00532 & 0.15373 & 0.17977\end{array}$

$\begin{array}{llllll}\text { AQUA REGIA } & 4 & 0.166750 & 0.00532 & 0.15373 & 0.17977 \\ \text { COLD CHEM } & 4 & 0.181500 & 0.00532 & 0.16848 & 0.19452\end{array}$

PEROXIDE FUSION

Std Error uses a pooled estimate of error variance

Means and Std Deviations

Level Number Mean Std Dev Std Err Mean Lower 95\% Upper 95\% $\begin{array}{lllllll}\text { AQUA REGIA } & 4 & 0.166750 & 0.014818 & 0.00741 & 0.14317 & 0.19033\end{array}$

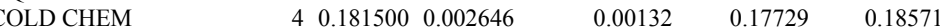
PEROXIDE FUSION
Tests that the Variances are Equal

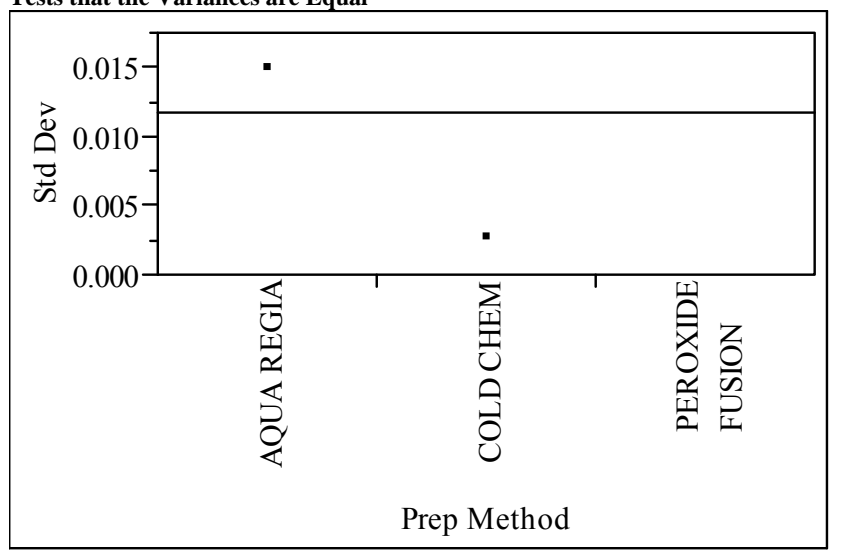

$\begin{array}{lrrrr}\text { Level } & \text { Count } & \text { Std Dev } & \text { MeanAbsDif to Mean } & \text { MeanAbsDif to Median } \\ \text { AQUA REGIA } & 4 & 0.0148183 & 0.0122500 & 0.0122500 \\ \text { COUD } & & 4 & 0.0026458 & 0.0020000\end{array}$

Count Std Dev MeanAbsDif to Mean MeanAbsDif to Median

COLDXIDE FUSION $\quad 0.026458-0.000000$

Test F Ratio DFNum DFDen Prob $>$ F

$\begin{array}{lllll}\text { O'Brien[.5] } & 5.5266 & 1 & 6 & 0.0570\end{array}$

$\begin{array}{lllll}\text { Brown-Forsythe } & 18.8876 & 1 & 6 & 0.0048 \\ \text { Levene } & 19.8543 & 1 & 6 & 0.0043\end{array}$

$\begin{array}{lrrrr}\text { Bartlett } & 5.4573 & 1 & 6 & 0.0043 \\ & & & & \end{array}$

Warning: Small sample sizes. Use Caution.

Welch Anova testing Means Equal, allowing Std Devs Not Equal

F Ratio DFNum DFDen Prob > F

$\begin{array}{rrrr}3.8408 & 1 & 3.1911 & 0.1394\end{array}$ 
Oneway Analysis of Measurement (Wt\%) By Prep Method Sample=SRAT Receipt, Element=A

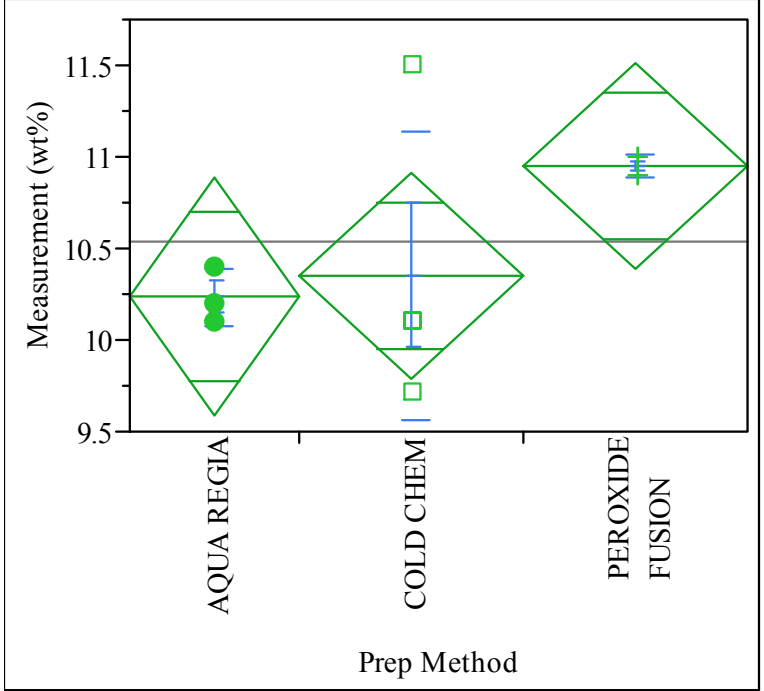

Missing Rows

1

Oneway Anova

Rsquare

Adj Rsquare

0.363956

0.204945

Root Mean Square Error $\quad 0.489099$

Mean of Response

10.53727
11

Analysis of Variance

Source DF Sum of Squares Mean Square F Ratio Prob $>$ F

$\begin{array}{llllll}\text { Prep Method } & 2 & 1.0950765 & 0.547538 & 2.2889 & 0.1637\end{array}$

$\begin{array}{lll}\text { Error } & 8 & 1.9137417\end{array}$

3.0088182

0.239218

Means for Oneway Anova

$\begin{array}{lrrrrr}\text { Level } & \text { Number } & \text { Mean } & \text { Std Error } & \text { Lower 95\% } & \text { Upper 95\% } \\ \text { AQUA REGIA } & 3 & 10.2333 & 0.28238 & 9.582 & 10.885 \\ \text { COLD CHEM } & 4 & 10.3525 & 0.24455 & 9.789 & 10.916 \\ \text { PEROXIDE FUSION } & 4 & 10.9500 & 0.24455 & 10.386 & 11.514\end{array}$

10.916

Std Error uses a pooled estimate of error variance

\section{Means and Std Deviations}

$\begin{array}{lrrrrrr}\text { Means and Std Deviations } & & & & & & \\ \text { Level } & \text { Number } & \text { Mean } & \text { Std Dev } & \text { Std Err Mean } & \text { Lower 95\% } & \text { Upper 95\% } \\ \text { AQUA REGIA } & 3 & 10.2333 & 0.152753 & 0.08819 & 9.854 & 10.613 \\ \text { COLD CHEM } & 4 & 10.3525 & 0.786781 & 0.39339 & 9.101 & 11.604 \\ \text { PEROXIDE FUSION } & 4 & 10.9500 & 0.057735 & 0.02887 & 10.858 & 11.042\end{array}$

Tests that the Variances are Equal

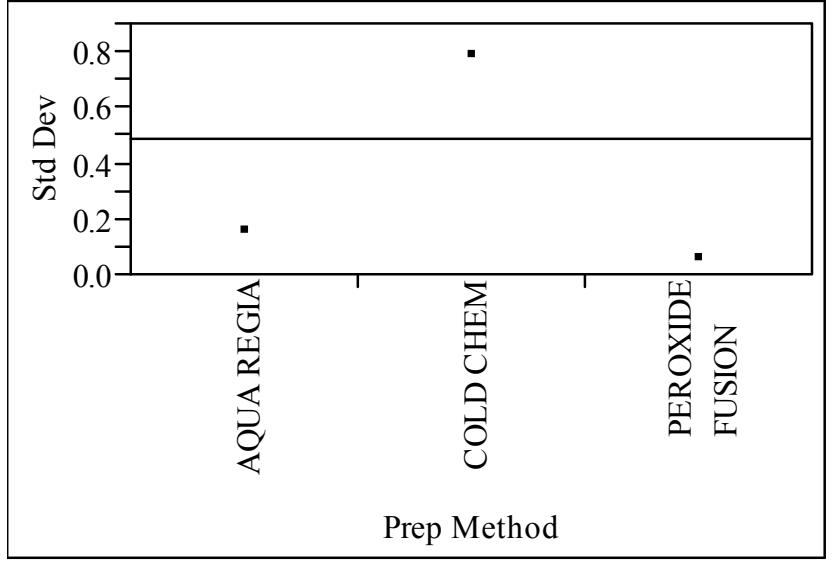

Level

AQUA REGIA

Count Std Dev MeanAbsDif to Mean MeanAbsDif to Median

COLD CHEM

$\begin{array}{ll}3 & 0.1527525 \\ 4 & 0.7867814 \\ 4 & 0.0577350\end{array}$

$\begin{array}{ll}4 & 0.7867814 \\ 4 & 0.0577350\end{array}$

0.1111111

0.0500000

0.1333333

PEROXIDE FUSION

Fatio DFNum DFDen Prob > F

O'Brien[-5] 1.2866

$\begin{array}{lllll}\text { Brown-Forsythe } & 1.0475 & 2 & 8 & 0.3944\end{array}$

$\begin{array}{lllll}\text { Levene } & 4.6300 & 2 & 8 & 0.0462 \\ \text { Bertlett } & 6.2299 & 2 & & 0.0020\end{array}$

Warning: Small sample sizes. Use Caution.

Welch Anova testing Means Equal, allowing Std Devs Not Equal

F Ratio DFNum DFDen Prob $>$ F

$25.9134 \quad 2 \quad 3.5946$

Means Comparisons

Comparisons for all pairs using Tukey-Kramer HSD

Level

Mean

PEROXIDE FUSION A 10.950000

$\begin{array}{ll}\text { COLD CHEM } & \text { A } 10.352500 \\ \text { AQUA REGIA } & \text { A } 10.233333\end{array}$

Levels not connected by same letter are significantly different. 
Oneway Analysis of Measurement (Wt\%) By Prep Method Sample=SRAT Receipt, Element=B

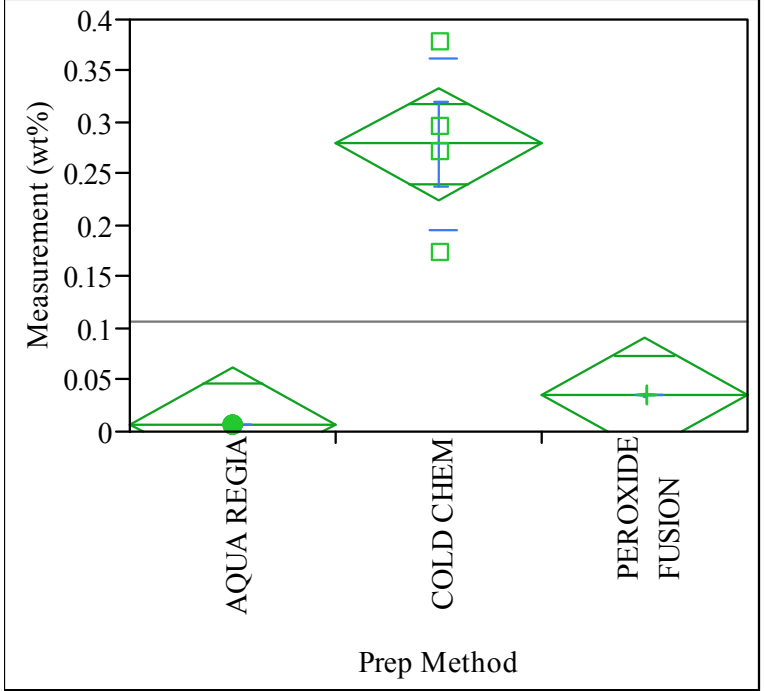

Oneway Anova

Summary of Fi

$\begin{array}{lr}\text { Rsquare } & 0.894305 \\ \text { Adj Rsquare } & 0.870817 \\ \text { Root Mean Square Error } & 0.048488 \\ \text { Mean of Response } & 0.10703 \\ \text { Observations (or Sum Wgts) } & 12\end{array}$

Analysis of Variance

Source DF Sum of Squares Mean Square F Ratio Prob > F

$\begin{array}{lllllll}\text { Prep Method } 2 & 0.17903934 & 0.089520 & 38.0752 & <.000\end{array}$

$\begin{array}{lrrr}\text { Error } & 9 & 0.02116016 & 0.002351 \\ \text { C. Total } & 11 & 0.20019950 & \end{array}$

Means for Oneway Anova

$\begin{array}{lrrrrr}\text { Level } & \text { Number } & \text { Mean } & \text { Std Error } & \text { Lower 95\% } & \text { Upper 95\% } \\ \text { AQUA REGIA } & 4 & 0.006915 & 0.02424 & -0.0479 & 0.06176 \\ \text { COLD CHEM } & 4 & 0.279000 & 0.02424 & 0.2242 & 0.33384 \\ \text { PEROXIDE FUSION } & 4 & 0.035175 & 0.02424 & -0.0197 & 0.09002\end{array}$

Std Error uses a pooled estimate of error variance

$\begin{array}{lrrrrrr}\text { Means and Std Deviations } & & & & & \\ \text { Level } & \text { Number } & \text { Mean } & \text { Std Dev } & \text { Std Err Mean } & \text { Lower 95\% } & \text { Upper 95\% } \\ \text { AQUA REGIA } & 4 & 0.006915 & 0.000068 & 3.4 \mathrm{e}-5 & 0.00681 & 0.00702\end{array}$

$\begin{array}{llllrrr}\text { AQUA REGIA } & 4 & 0.006915 & 0.000068 & 3.4 \mathrm{e}-5 & 0.00681 & 0.00702 \\ \text { COLD CHEM } & 4 & 0.279000 & 0.083984 & 0.04199 & 0.14536 & 0.41264\end{array}$

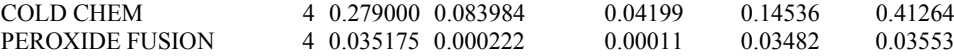

Tests that the Variances are Equal

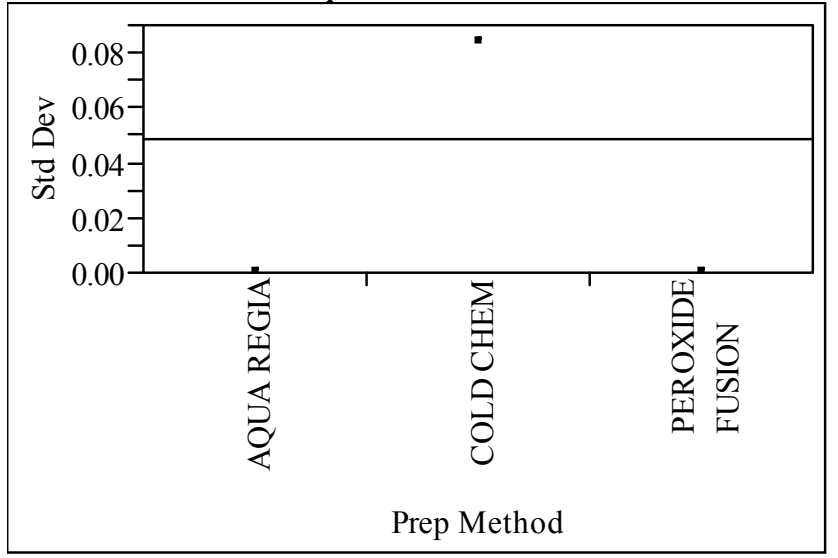

$\begin{array}{lrrrr}\text { Level } & \text { Count } & \text { Std Dev } & \text { MeanAbsDif to Mean } & \text { MeanAbsDif to Median } \\ \text { AQUA REGIA } & 4 & 0.0000681 & 0.0000475 & 0.0000450\end{array}$

$0.0570000 \quad 0.0000450$

$\begin{array}{llll}\text { PEROXIDE FUSION } & 40.0002217 & 0.0001625 & 0.0570000 \\ & & \end{array}$

Test F Ratio DFNum DFDen Prob $>$ F

$\begin{array}{lllll}\text { O'Brien[.5] } & 2.0158 & 2 & 9 & 0.1891\end{array}$

$\begin{array}{lllll}\text { Brown-Forsythe } & 4.7243 & 2 & 9 & 0.0396 \\ \text { Levene } & 4.7580 & 2 & 9 & 0.0389\end{array}$

$\begin{array}{lllll}\text { Bartlett } & 29.8050 & 2 & <.0001\end{array}$

Warning: Small sample sizes. Use Caution.

Welch Anova testing Means Equal, allowing Std Devs Not Equal

$\begin{array}{rrrr}\text { F Ratio } & \text { DFNum } & \text { DFDen } & \text { Prob }>\text { F } \\ 25754.755 & 2 & 4.3417 & <.0001\end{array}$

Means Comparisons

Comparisons for all pairs using Tukey-Kramer HSD

Level

COLD CHEM A 0.27900000

PEROXIDE FUSION B 0.03517500

AQUA REGIA $\quad$ B 0.00691500

Levels not connected by same letter are significantly different. 
Oneway Analysis of Measurement (Wt\%) By Prep Method Sample=SRAT Receipt, Element=Ca

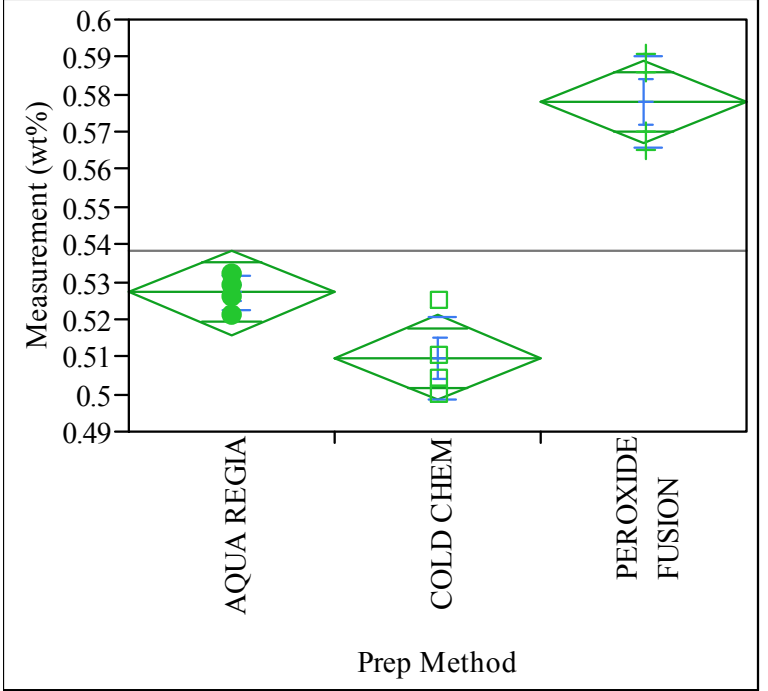

Oneway Anova

Summary of Fi

$\begin{array}{lr}\text { Rsquare } & 0.918606 \\ \text { Adj Rsquare } & 0.900518 \\ \text { Root Mean Square Error } & 0.00996 \\ \text { Mean of Response } & 0.53825 \\ \text { Observations (or Sum Wgts) } & 12\end{array}$

Analysis of Variance

Source DF Sum of Squares Mean Square F Ratio Prob $>$ F

$\begin{array}{lllllll}\text { Prep Method } & 2 & 0.01007550 & 0.005038 & 50.7866 & <.0001\end{array}$

$\begin{array}{lrrr}\text { Error } & 9 & 0.00089275 & 0.000099 \\ \text { C. Total } & 11 & 0.01096825 & \end{array}$

Means for Oneway Anova

$\begin{array}{lrrrrr}\text { Level } & \text { Number } & \text { Mean } & \text { Std Error } & \text { Lower 95\% } & \text { Upper 95\% } \\ \text { AQUA REGIA } & 4 & 0.527000 & 0.00498 & 0.51573 & 0.53827 \\ \text { COLD CHEM } & 4 & 0.509750 & 0.00498 & 0.49848 & 0.52102 \\ \text { PEROXIDE FUSION } & 4 & 0.578000 & 0.00498 & 0.56673 & 0.58927\end{array}$

Std Error uses a pooled estimate of error variance

\section{Means and Std Deviations}

$\begin{array}{lrrrrrr}\text { Level } & \text { Number } & \text { Mean } & \text { Std Dev } & \text { Std Err Mean } & \text { Lower 95\% } & \text { Upper 95\% } \\ \text { AQUA REGIA } & 4 & 0.527000 & 0.004690 & 0.00235 & 0.51954 & 0.53446\end{array}$

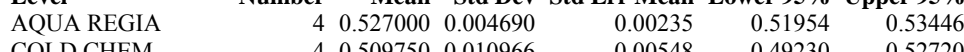

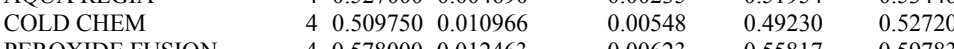

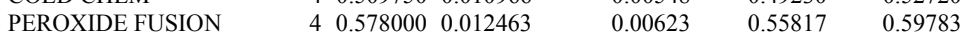

Tests that the Variances are Equal

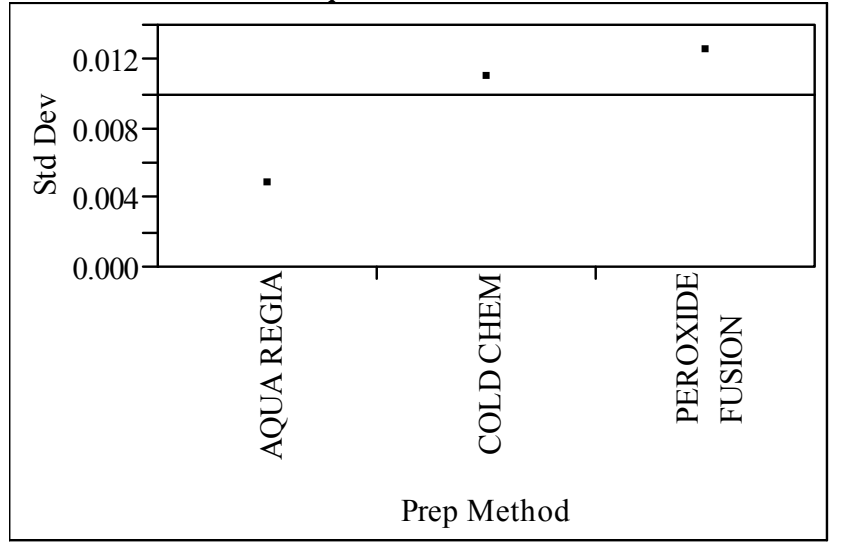

Level Count Std Dev MeanAbsDif to Mean MeanAbsDif to Median

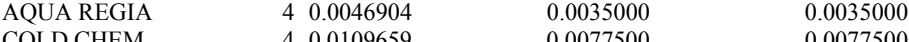

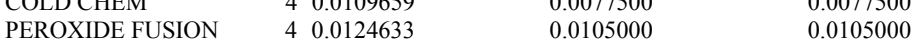

Test F Ratio DFNum DFDen Prob $>$ F

$\begin{array}{lllll}\text { O'Brien[.5] } & 1.4214 & 2 & 9 & 0.2908 \\ \text { Brown-Forsythe } & 2.3110 & 2 & 9 & 0.1549\end{array}$

$\begin{array}{lllll}\text { Brown-Forsythe } & 2.3110 & 2 & 9 & 0.1549 \\ \text { Levene } & 2.7554 & 2 & 9 & 0.1165\end{array}$

$\begin{array}{lllll}\text { Bartlett } & 1.1302 & 2 & . & 0.3230\end{array}$

Warning: Small sample sizes. Use Caution.

Welch Anova testing Means Equal, allowing Std Devs Not Equal

F Ratio DFNum DFDen Prob > F

$\begin{array}{llll}32.9133 & 2 & 4.9985 & 0.0013\end{array}$

Means Comparisons

Comparisons for all pairs using Tukey-Kramer HSD

Level Mean

PEROXIDE FUSION A 0.57800000

AQUA REGIA $\quad$ B 0.52700000

Levels not connected by same letter are significantly different. 
Oneway Analysis of Measurement (Wt\%) By Prep Method Sample=SRAT Receipt, Element=Cr

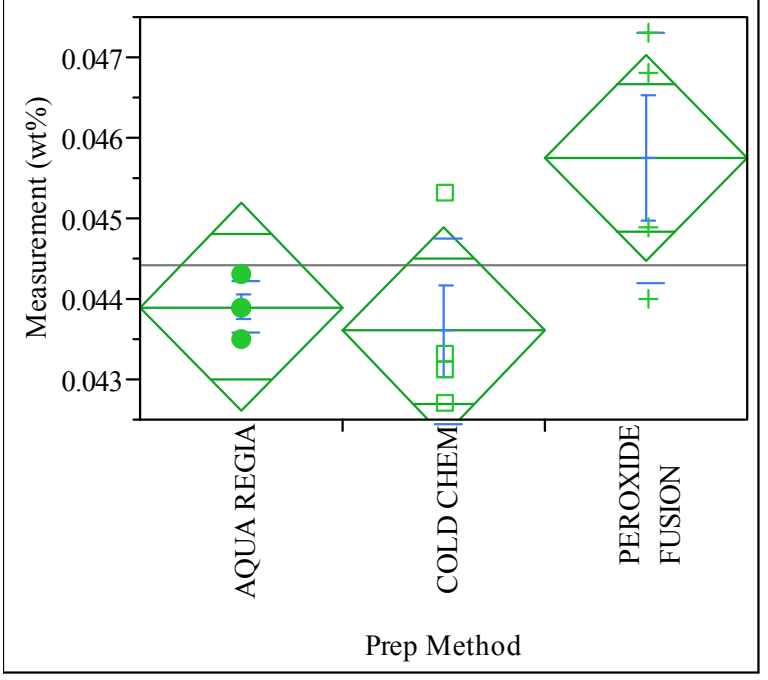

Oneway Anova

Summary of Fit

$\begin{array}{lr}\text { Rsquare } & 0.482146 \\ \text { Adj Rsquare } & 0.367067 \\ \text { Root Mean Square Error } & 0.001138 \\ \text { Mean of Response } & 0.044417 \\ \text { Observations (or Sum Wgts) } & 12\end{array}$

Analysis of Variance

Source DF Sum of Squares Mean Square F Ratio Prob > F

$\begin{array}{lrrrrr}\text { Source } & \text { DF } & \text { Sum of Squares } & & & \\ \text { Prep Method } & 2 & 0.00001085 & 5.4233 \mathrm{e}-6 & 4.1897 & 0.0518\end{array}$

$\begin{array}{llll}\text { Prep Method } & 2 & 0.00001085 & 5.4233 \mathrm{e}-6 \\ \text { Error } & 9 & 0.00001165 & 1.2944 \mathrm{e}-6\end{array}$

$\begin{array}{lrr}\text { C. Total } & 11 & 0.00002250\end{array}$

Means for Oneway Anova

Level Number Mean Std Error Lower 95\% Upper 95\%

$\begin{array}{llllll}\text { AQUA REGIA } & 4 & 0.043900 & 0.00057 & 0.04261 & 0.04519\end{array}$

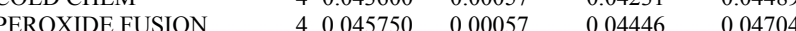

Std Error uses a pooled estimate of error variance

$\begin{array}{lrrrrrr}\text { Means and Std Deviations } & & & & & & \\ \text { Level } & \text { Number } & \text { Mean } & \text { Std Dev } & \text { Std Err Mean } & \text { Lower 95\% } & \text { Upper 95\% } \\ \text { AQUA REGIA } & 4 & 0.043900 & 0.000327 & 0.00016 & 0.04338 & 0.04442 \\ \text { COLD CHEM } & 4 & 0.043600 & 0.001160 & 0.00058 & 0.04175 & 0.04545 \\ \text { PEROXIDE FUSION } & 4 & 0.045750 & 0.001559 & 0.00078 & 0.04327 & 0.04823\end{array}$

Tests that the Variances are Equal

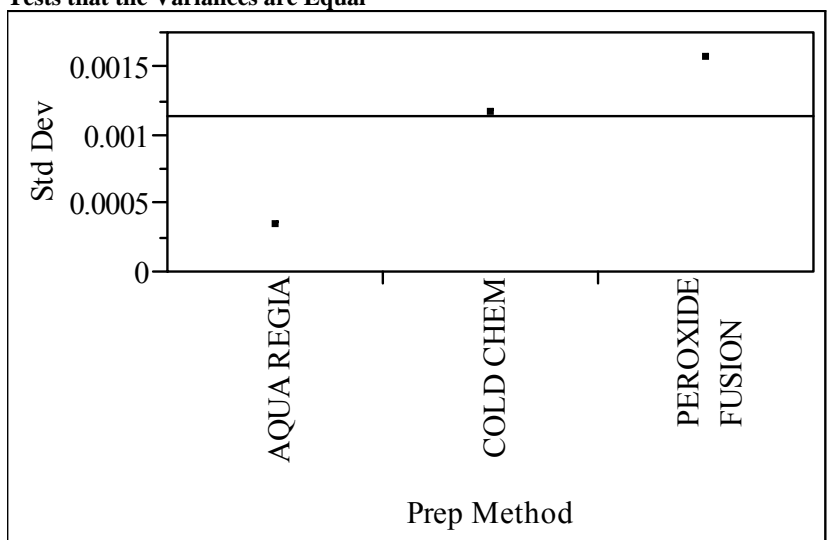

Level
AQUA REGIA

Count Std Dev MeanAbsDif to Mean MeanAbsDif to Median

COLD CHEM

$\begin{array}{lll}4 & 0.0003266 & 0.0002000 \\ 4 & 0.0011605 & 0.0008500\end{array}$

0.0002000

CHEM

$\begin{array}{ll}4 & 0.0011605 \\ 4 & 0.0015588\end{array}$

0.0008500

0.0007000

Test F Ratio DFNum DFDen Prob $>$ F

$\begin{array}{lllll}\text { O'Brien[.5] } & 2.0305 & 2 & 9 & 0.1872 \\ & 3.1652 & 2 & 9 & 0.0910\end{array}$

$\begin{array}{lllll}\text { Brown-Forsythe } & 3.1652 & 2 & 9 & 0.0910 \\ \text { Levene } & 5.9837 & 2 & 9 & 0.0222\end{array}$

$\begin{array}{lllll}\text { Bartlett } & 2.3866 & 2 & . & 0.0919\end{array}$

Warning: Small sample sizes. Use Caution.

Welch Anova testing Means Equal, allowing Std Devs Not Equal

F Ratio DFNum DFDen Prob > F

Means Comparisons

Comparisons for all pairs using Tukey-Kramer HSD

Level

Mean

PEROXIDE FUSION A 0.04575000

AQUA REGIA A 0.04390000

Levels not connected by same letter are significantly different. 
Oneway Analysis of Measurement (Wt\%) By Prep Method Sample=SRAT Receipt, Element=Cu

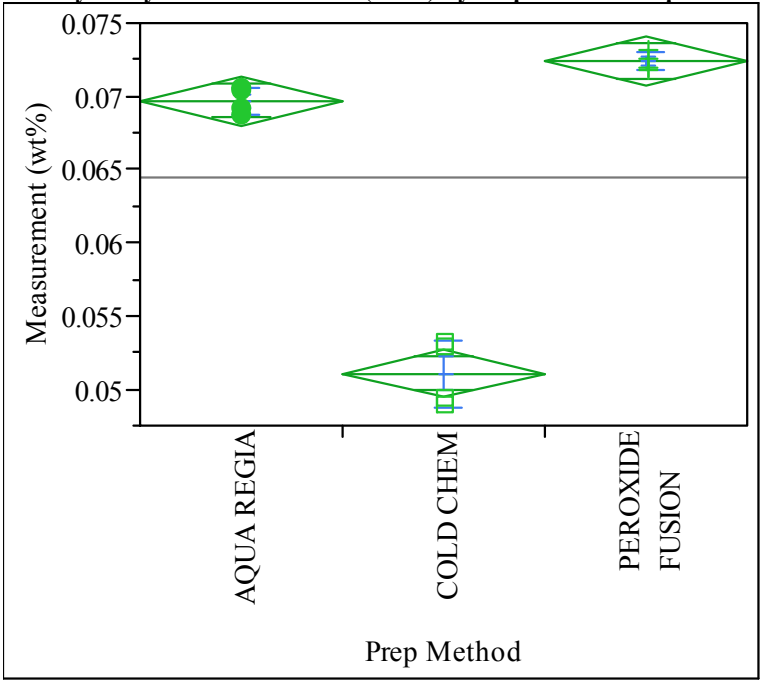

Oneway Anova

Summary of Fit

$\begin{array}{lr}\text { Rsquare } & 0.982414 \\ \text { Adj Rsquare } & 0.978506 \\ \text { Root Mean Square Error } & 0.001465 \\ \text { Mean of Response } & 0.064392 \\ \text { Observations (or Sum Wgts) } & 12\end{array}$

0.064392

Analysis of Variance

Source DF Sum of Squares Mean Square F Ratio Prob $>$ F

$\begin{array}{rrrrrr}\text { Source } & \text { DF } & \text { Sum of Squares } & \text { Mean Square } & \text { F Ratio } & \text { Prob }>\text { F } \\ \text { Prep Method } & 2 & 0.00107858 & 0.000539 & 251.3851 & <.0001\end{array}$

$\begin{array}{lll}\text { Prep Method } & 2 & 0.00107858 \\ \text { Error } & 9 & 0.00001931\end{array}$

$2.145 \mathrm{e}-6$

$\begin{array}{lll}\text { C. Total } & 11 & 0.00109789\end{array}$

Means for Oneway Anova

Level Number Mean Std Error Lower 95\% Upper 95\%

$\begin{array}{llllll}\text { AQUA REGIA } & 4 & 0.069700 & 0.00073 & 0.06804 & 0.07136\end{array}$

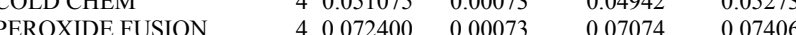

Std Error uses a pooled estimate of error variance

$\begin{array}{lrrrrrr}\text { Means and Std Deviations } & & & & & & \\ \text { Level } & \text { Number } & \text { Mean } & \text { Std Dev } & \text { Std Err Mean } & \text { Lower 95\% } & \text { Upper 95\% } \\ \text { AQUA REGIA } & 4 & 0.069700 & 0.000891 & 0.00045 & 0.06828 & 0.07112 \\ \text { COLD CHEM } & 4 & 0.051075 & 0.002290 & 0.00114 & 0.04743 & 0.05472 \\ \text { PEROXIDE FUSION } & 4 & 0.072400 & 0.000632 & 0.00032 & 0.07139 & 0.07341\end{array}$

Tests that the Variances are Equal

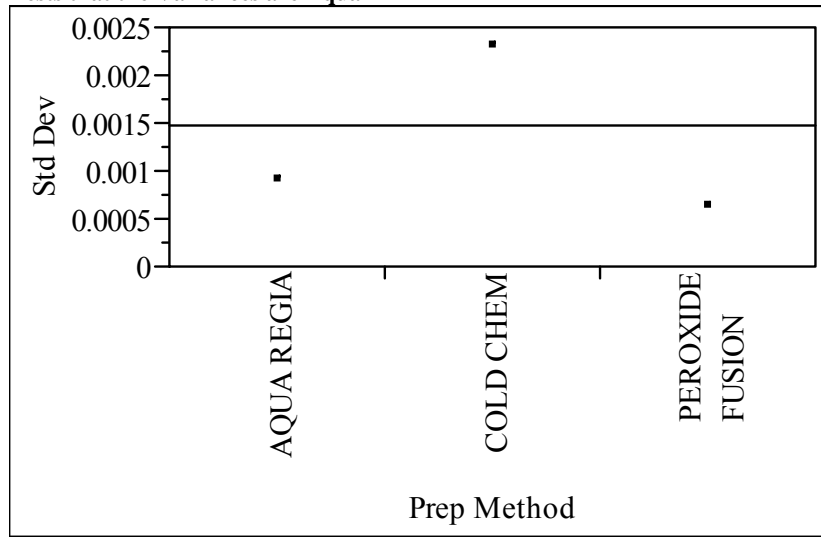

Level

Count Std Dev MeanAbsDif to Mean MeanAbsDif to Median

COLD CHEM

\begin{tabular}{rrr}
4 & 0.0008907 & 0.0007500 \\
4 & 0.0022897 & 0.0019750 \\
\hline & 0.0006325 & 0.0005000
\end{tabular}

0.0005000

0.0007500

CHEM

40.0006325

.0019750

Test F Ratio DFNum DFDen Prob $>$ F

$\begin{array}{lllll}\text { O'Brien[.5] } & 38.2139 & 2 & 9 & <.0001 \\ \text { Brown-Forsythe } & 41.7349 & 2 & 9 & <.0001 \\ \text { Levene } & 49.3022 & 2 & 9 & <.0001\end{array}$

$\begin{array}{lrrrr}\text { Levene } & 49.3022 & 2 & 9 & <.0001 \\ \text { Bartlett } & 2.3265 & 2 & . & 0.0976\end{array}$

Warning: Small sample sizes. Use Caution.

Welch Anova testing Means Equal, allowing Std Devs Not Equal

F Ratio DFNum DFDen Prob > F

$145.3865<2 \quad 2.3177<0001$

Means Comparisons

Comparisons for all pairs using Tukey-Kramer HSD

Level

PEROXIDE FUSION A 0.07240000

AQUA REGIA A 0.06970000

COLD CHEM $\quad$ B 0.05107500

Levels not connected by same letter are significantly different. 
Oneway Analysis of Measurement (Wt\%) By Prep Method Sample=SRAT Receipt, Element=Fe

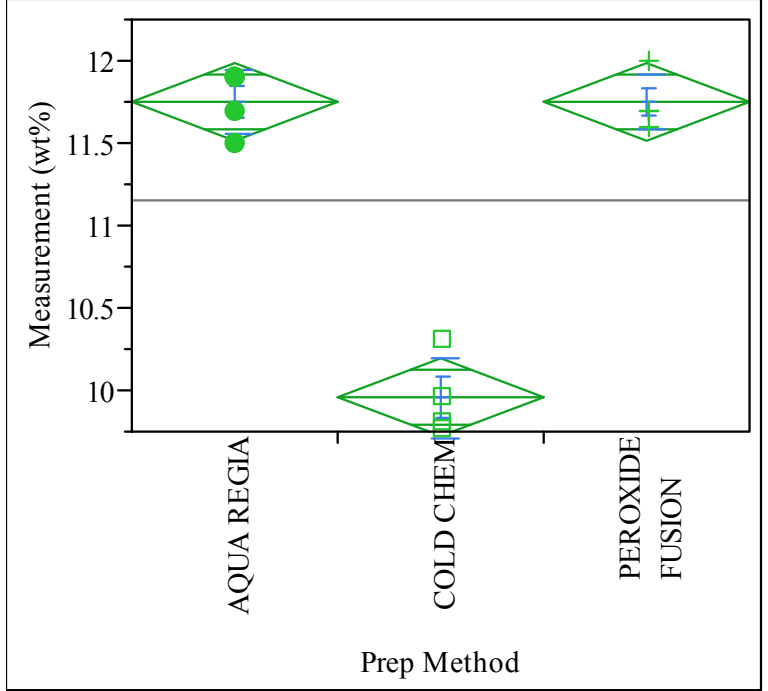

Oneway Anova

Summary of Fi

$\begin{array}{lr}\text { Rsquare } & 0.957825 \\ \text { Adj Rsquare } & 0.948453 \\ \text { Root Mean Square Error } & 0.204742 \\ \text { Mean of Response } & 11.1525 \\ \text { Observations (or Sum Wgts) } & 12\end{array}$

Analysis of Variance

Source DF Sum of Squares Mean Square F Ratio Prob $>$ F

$\begin{array}{llllll}\text { Prep Method } & 2 & 8.5681500 & 4.28408 & 102.1978 & <.0001\end{array}$

$\begin{array}{lrrr}\text { Error } & 9 & 0.3772750 & 0.04192\end{array}$

$\begin{array}{lll}\text { C. Total } & 11 & 8.9454250\end{array}$

Means for Oneway Anova

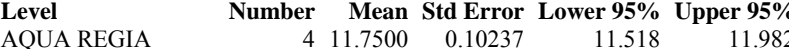

$\begin{array}{llllll} & 4 & \text { Mean } & 0.10237 & 11.518 & 11.982\end{array}$

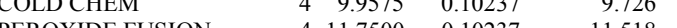

Std Error uses a pooled estimate of error variance

\section{Means and Std Deviations}

$\begin{array}{lrrrrrrr}\text { Means and Std Deviations } & \text { Number } & \text { Mean } & \text { Std Dev } & \text { Std Err Mean } & \text { Lower 95\% } & \text { Upper 95\% } \\ \text { Level } & 4 & 11.7500 & 0.191485 & 0.09574 & 11.445 & 12.055 \\ \text { AQUA REGIA } & 4 & 9.9575 & 0.243088 & 0.12154 & 9.571 & 10.344 \\ \text { COLD CHEM } & 4 & 11.7500 & 0.173205 & 0.08660 & 11.474 & 12.026\end{array}$

Tests that the Variances are Equal

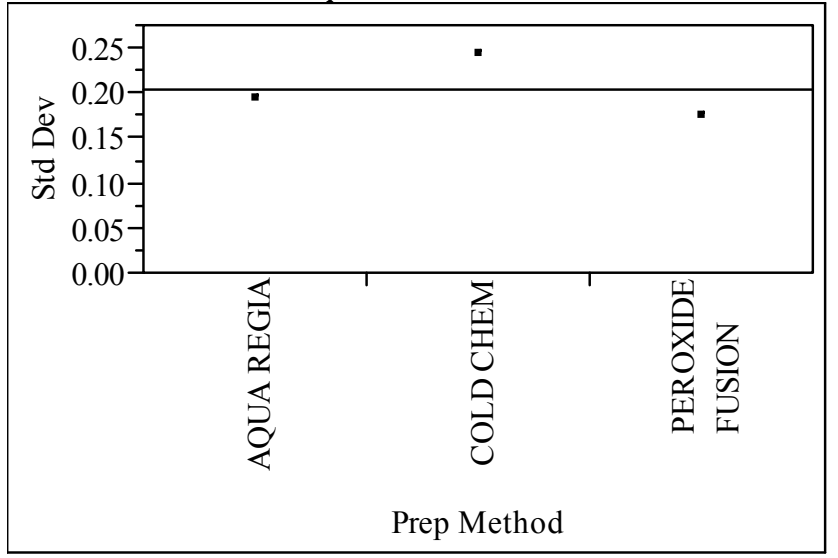

Leve

Count Std Dev MeanAbsDif to Mean MeanAbsDif to Median

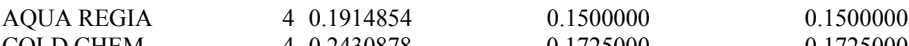

$\begin{array}{lllll}\text { COLD CHEM } & 4 & 0.2430878 & 0.1725000 & 0.1725000 \\ \text { PEROXIDE FUSION } & 4 & 0.1732051 & 0.1250000 & 0.1000000\end{array}$

Test F Ratio DFNum DFDen Prob $>$ F

$\begin{array}{lllll}\text { O'Brien[.5] } & 0.2497 & 2 & 9 & 0.7843\end{array}$

$\begin{array}{lllll}\text { Brown-Forsythe } & 0.2878 & 2 & 9 & 0.7566\end{array}$

$\begin{array}{lllll}\text { Levene } & 0.1922 & 2 & 9 & 0.8284 \\ \text { Bartlett } & 0.1634 & 2 & . & 0.8492\end{array}$

Warning: Small sample sizes. Use Caution.

Welch Anova testing Means Equal, allowing Std Devs Not Equal

F Ratio DFNum DFDen Prob $>$ F

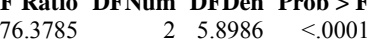

Means Comparisons

Comparisons for all pairs using Tukey-Kramer HSD

Level

AQUA REGIA A $\quad$ Mean

PEROXIDE FUSION A 11.750000

$\begin{array}{lll}\text { COLD CHEM } & \text { B } 9.957500\end{array}$

Levels not connected by same letter are significantly different. 
Oneway Analysis of Measurement (Wt\%) By Prep Method Sample=SRAT Receipt, Element=K

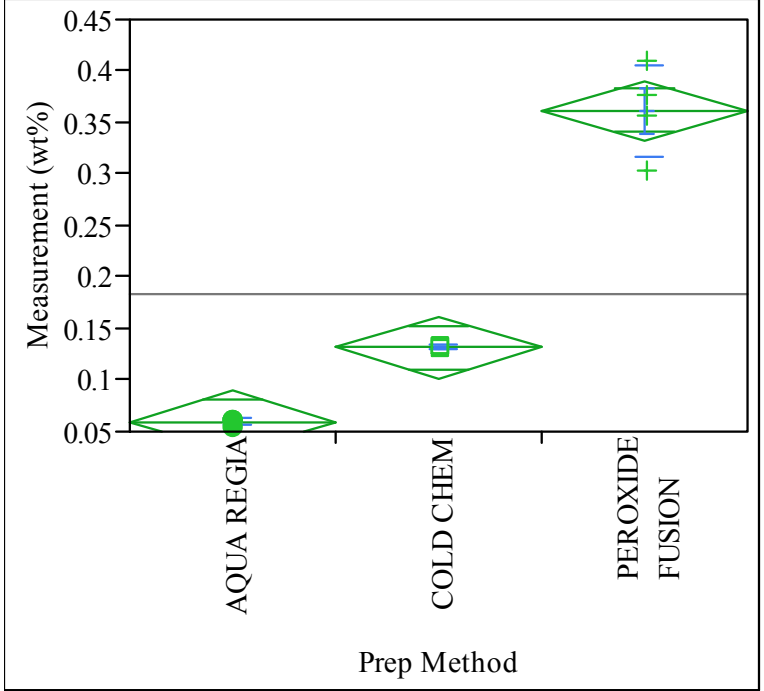

Oneway Anova

Summary of Fi

$\begin{array}{lr}\text { Rsquare } & 0.969992 \\ \text { Adj Rsquare } & 0.963324 \\ \text { Root Mean Square Error } & 0.026151 \\ \text { Mean of Response } & 0.18425 \\ \text { Observations (or Sum Wgts) } & 12\end{array}$

Analysis of Variance

Source DF Sum of Squares Mean Square F Ratio Prob $>$ F

$\begin{array}{lllllll}\text { Prep Method } & 2 & 0.19894550 & 0.099473 & 145.4599 & <.0001\end{array}$

$0.00615465-0.000684$

$\begin{array}{lll}\text { C. Total } & 11 & 0.20510015\end{array}$

Means for Oneway Anova

$\begin{array}{lrrrrr}\text { Level } & \text { Number } & \text { Mean } & \text { Std Error } & \text { Lower 95\% } & \text { Upper 95\% } \\ \text { AQUA REGIA } & 4 & 0.059500 & 0.01308 & 0.02992 & 0.08908 \\ \text { COLD CHEM } & 4 & 0.131750 & 0.01308 & 0.10217 & 0.16133\end{array}$

$\begin{array}{llllll}\text { COLD CHEM } & 4 & 0.131750 & 0.01308 & 0.10217 & 0.16133 \\ \text { PEROXIDE FUSION } & 4 & 0.361500 & 0.01308 & 0.33192 & 0.39108\end{array}$

Std Error uses a pooled estimate of error variance

$\begin{array}{lrrrrrr}\text { Means and Std Deviations } & & & & & & \\ \text { Level } & \text { Number } & \text { Mean } & \text { Std Dev } & \text { Std Err Mean } & \text { Lower 95\% } & \text { Upper 95\% } \\ \text { AQUA REGIA } & 4 & 0.059500 & 0.003209 & 0.00160 & 0.05439 & 0.06461\end{array}$

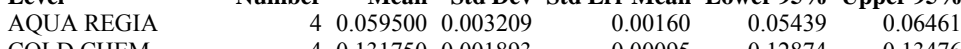

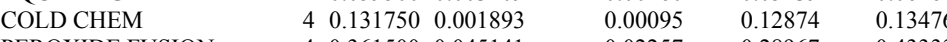

$\begin{array}{lllllll}\text { PEROXIDE FUSION } & 4 & 0.361500 & 0.045141 & 0.02257 & 0.28967 & 0.43333\end{array}$
Tests that the Variances are Equal

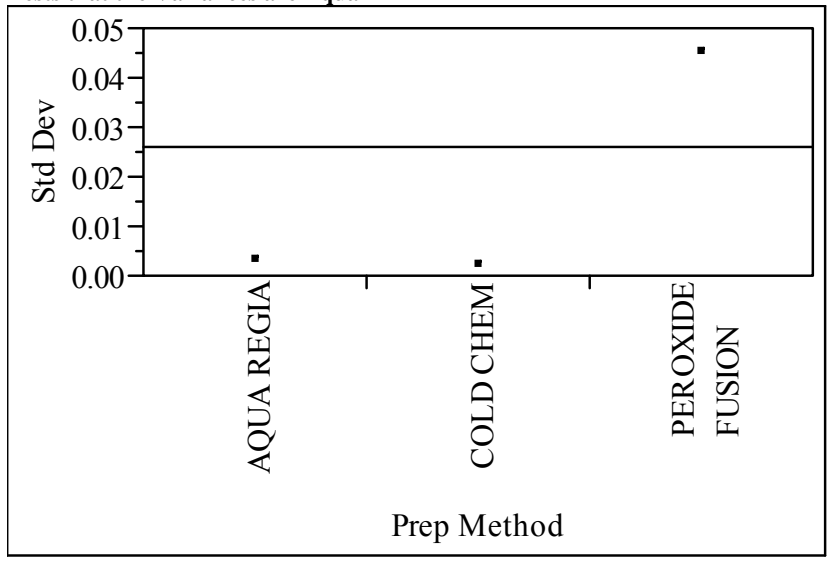

Leve

Count Std Dev MeanAbsDif to Mean MeanAbsDif to Median

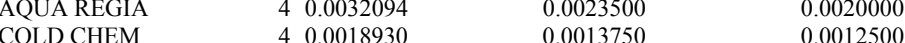

$\begin{array}{lllll} & 4 & 0.0018930 & 0.0013750 & 0.0012500 \\ \text { PEROXIDE FUSION } & 4 & 0.0451405 & 0.0320000 & 0.0320000\end{array}$

Test F Ratio DFNum DFDen Prob $>$ F

$\begin{array}{lllll}\text { O'Brien[.5] } & 2.1161 & 2 & 9 & 0.1765\end{array}$

$\begin{array}{lrrrr}\text { Brown-Forsythe } & 5.2127 & 2 & 9 & 0.0314 \\ \text { Levene } & 5.3759 & 2 & 9 & 0.0291\end{array}$

$\begin{array}{lrrrr}\text { Bartlett } & 10.9157 & 2 & <.0001\end{array}$

Warning: Small sample sizes. Use Caution.

Welch Anova testing Means Equal, allowing Std Devs Not Equal

$\begin{array}{rrrr}\text { F Ratio } & \text { DFNum } & \text { DFDen } & \text { Prob }>\text { F } \\ 716.0749 & 2 & 4.9523 & <.0001\end{array}$

Means Comparisons

Comparisons for all pairs using Tukey-Kramer HSD

Level

$\begin{array}{lr}\text { Level } & \text { Mean } \\ \text { PEROXIDE FUSION A } & 0.36150000\end{array}$

COLD CHEM $\quad$ B 0.13175000

AQUA REGIA C 0.05950000

Levels not connected by same letter are significantly different. 
Oneway Analysis of Measurement (Wt\%) By Prep Method Sample=SRAT Receipt, Element=L

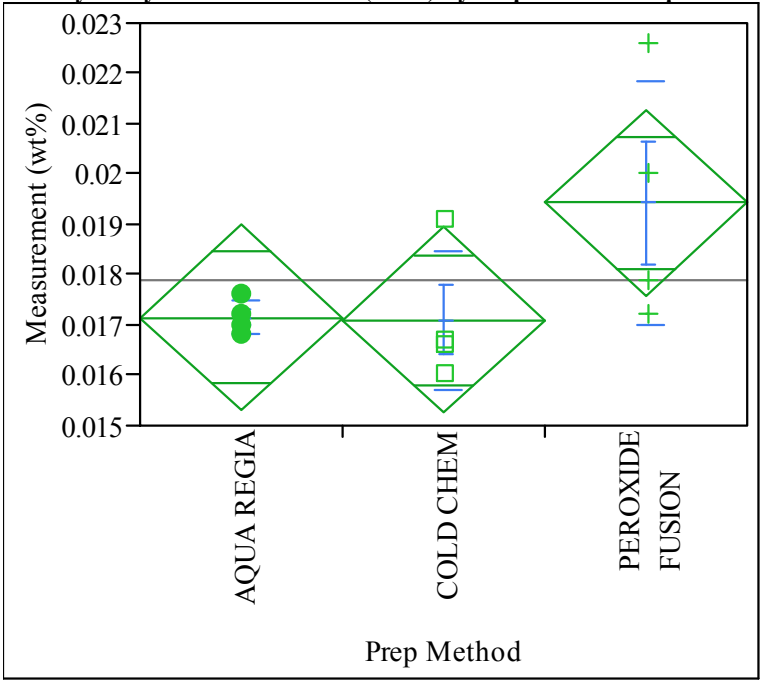

Oneway Anova

Summary of Fit

$\begin{array}{lr}\text { Rsquare } & 0.373629 \\ \text { Adj Rsquare } & 0.234436 \\ \text { Root Mean Square Error } & 0.001621 \\ \text { Mean of Response } & 0.017892 \\ \text { Observations (or Sum Wgts) } & 12\end{array}$

Analysis of Variance

Source DF Sum of Squares Mean Square F Ratio Prob $>$ F

$\begin{array}{lrrrrr}\text { Prep Method } & 2 & 0.00001411 & 7.0558 \mathrm{e}-6 & 2.6842 & 0.1218\end{array}$

$\begin{array}{llll}\text { Error } & 9 & 0.00002366 & 2.6286 \mathrm{e}-6\end{array}$

$\begin{array}{lrr}\text { C. Total } & 11 & 0.00003777\end{array}$

Means for Oneway Anova

Level Number Mean Std Error Lower 95\% Upper 95\%

$\begin{array}{llllll}\text { AQUA REGIA } & 4 & 0.017150 & 0.00081 & 0.01532 & 0.01898\end{array}$

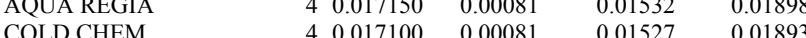

$\begin{array}{llllll} & 4 & 0.017150 & 0.00081 & 0.01532 & 0.01898 \\ \text { PEROXIDE FUSION } & 4 & 0.019425 & 0.00081 & 0.01527 & 0.01893 \\ & & & & & \end{array}$

Std Error uses a pooled estimate of error variance

$\begin{array}{lrrrrrr}\text { Means and Std Deviations } & & & & & & \\ \text { Level } & \text { Number } & \text { Mean } & \text { Std Dev } & \text { Std Err Mean } & \text { Lower 95\% } & \text { Upper 95\% } \\ \text { AQUA REGIA } & 4 & 0.017150 & 0.000342 & 0.00017 & 0.01661 & 0.01769 \\ \text { COLD CHEM } & 4 & 0.017100 & 0.001369 & 0.00068 & 0.01492 & 0.01928 \\ \text { PEROXIDE FUSION } & 4 & 0.019425 & 0.002428 & 0.00121 & 0.01556 & 0.02329\end{array}$

Tests that the Variances are Equal

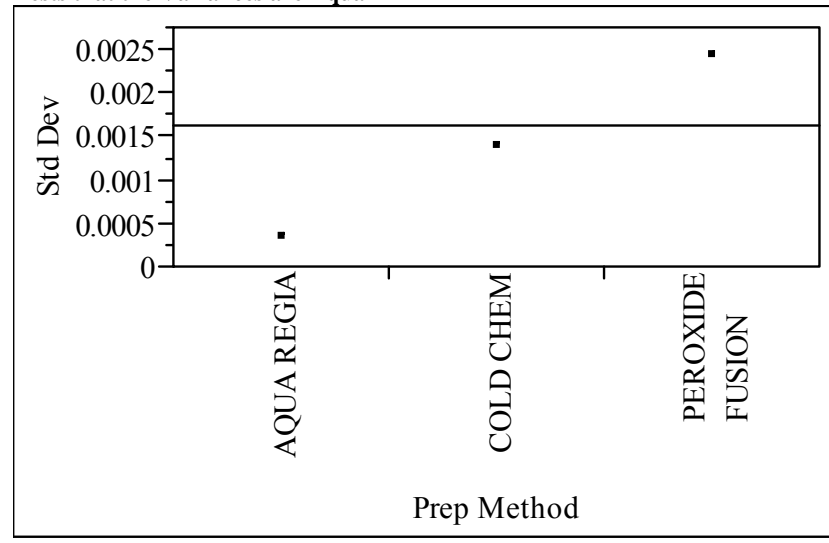

Level
AQUA REGIA

Count Std Dev MeanAbsDif to Mean MeanAbsDif to Median

COLD CHEM

$\begin{array}{lll}4 & 0.0003416 & 0.0002500 \\ 4 & 0.0013687 & 0.0010000\end{array}$

0.0018750

0.0002500

PEROXIDE FUSION $\quad 4 \quad 0.002428$

0.0008000

Test F Ratio DFNum DFDen Prob $>$ F

\begin{tabular}{lllll} 
O'Brien[.5] & 1.8024 & 2 & 9 & 0.2196 \\
\hline & 4.8907 & 2 & 9 & 0.1072
\end{tabular}

$\begin{array}{lllll}\text { Brown-Forsythe } & 2.8907 & 2 & 9 & 0.1072 \\ \text { Levene } & 4.4551 & 2 & 9 & 0.0452\end{array}$

$\begin{array}{lllll}\text { Bartlett } & 3.4567 & 2 & .04315\end{array}$

Warning: Small sample sizes. Use Caution.

Welch Anova testing Means Equal, allowing Std Devs Not Equal

F Ratio DFNum DFDen Prob $>$ F

1.4985

Means Comparisons

Comparisons for all pairs using Tukey-Kramer HSD

Level

Mean

PEROXIDE FUSION A 0.01942500

$\begin{array}{ll}\text { AQUA REGIA } & \text { A } 0.01715000 \\ \text { COLD CHEM } & \text { A } 0.01710000\end{array}$

Levels not connected by same letter are significantly different. 
Oneway Analysis of Measurement (Wt\%) By Prep Method Sample=SRAT Receipt, Element=Mg

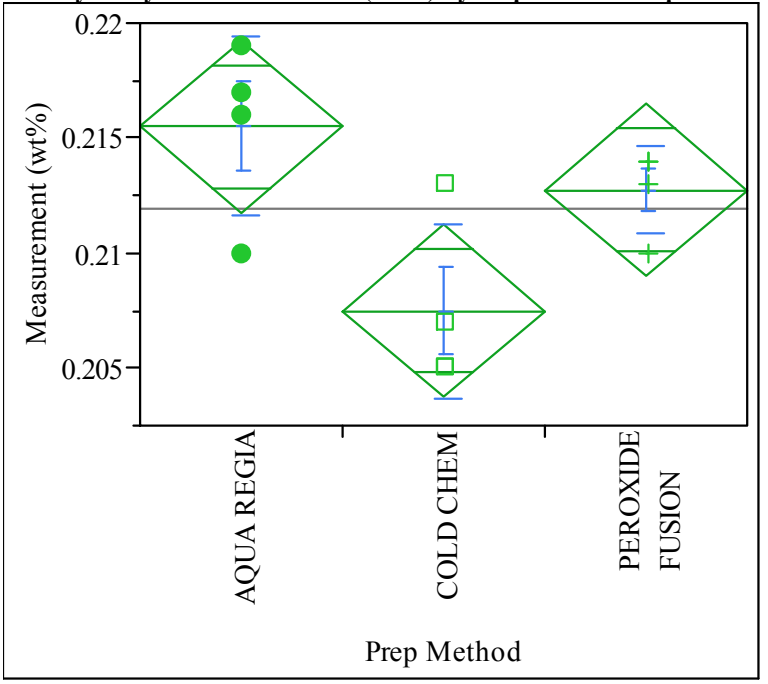

Oneway Anova

Summary of Fit

$\begin{array}{lr}\text { Rsquare } & 0.572357 \\ \text { Adj Rsquare } & 0.477325 \\ \text { Root Mean Square Error } & 0.003312 \\ \text { Mean of Response } & 0.211917 \\ \text { Observations (or Sum Wgts) } & 12\end{array}$

Analysis of Variance

Source DF Sum of Squares Mean Square F Ratio Prob $>$ F

$\begin{array}{lrrrrr}\text { Prep Method } & 2 & 0.00013217 & 0.000066 & 6.0228 & 0.0219\end{array}$

$\begin{array}{llll}\text { Prep Method } & 2 & 0.00013217 & 0.000066 \\ \text { Error } & 9 & 0.00009875 & 0.000011\end{array}$

$\begin{array}{lrr}\text { C. Total } & 11 & 0.00023092\end{array}$

Means for Oneway Anova

Level Number Mean Std Error Lower 95\% Upper 95\%

$\begin{array}{llllll}\text { AQUA REGIA } & 4 & 0.215500 & 0.00166 & 0.21175 & 0.21925 \\ \text { COLD } & 4 & 0.207500 & 0.00166 & 0.20375 & 0.21125\end{array}$

\begin{tabular}{llllll} 
& 4 & 0.215500 & 0.00166 & 0.21175 & 0.21925 \\
PEROXIDE FUSION & 4 & 0.207500 & 0.00166 & 0.20375 & 0.21125 \\
\hline
\end{tabular}

Std Error uses a pooled estimate of error variance

Means and Std Deviations

Level Number Mean Std Dev Std Err Mean Lower 95\% Upper 95\%

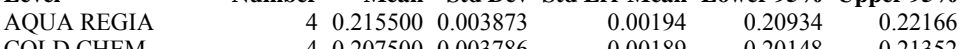

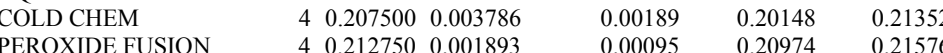

Tests that the Variances are Equal

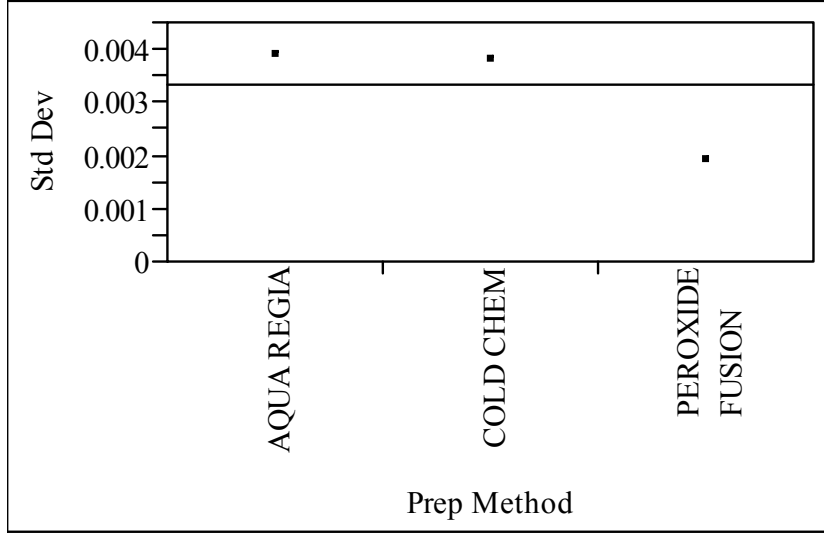

Level

Count Std Dev MeanAbsDif to Mean MeanAbsDif to Median

COLD CHEM

$\begin{array}{lrr}4 & 0.0038730 & 0.0027500 \\ 4 & 0.0037859 & 0.0027500\end{array}$

0.0013750

0.0025000

PEROXIDE FUSION $\quad 40.0018930$

0.0025000

Test F Ratio DFNum DFDen Prob $>$ F

$\begin{array}{lllll}\text { O'Brien[.5] } & 0.4717 & 2 & 9 & 0.6386 \\ \text { Brown-Forsythe } & 0.3247 & 2 & 9 & 0.7309\end{array}$

$\begin{array}{lllll}\text { Brown-Forsythe } & 0.3247 & 2 & 9 & 0.7309 \\ \text { Levene } & 0.7393 & 2 & 9 & 0.5043\end{array}$

$\begin{array}{lllll}\text { Bartlett } & 0.7044 & 2 & 0.4944\end{array}$

Warning: Small sample sizes. Use Caution.

Welch Anova testing Means Equal, allowing Std Devs Not Equal

F Ratio DFNum DFDen Prob $>$ F

Means Comparisons

Comparisons for all pairs using Tukey-Kramer HSD

Level

A 0.21550000

PEROXIDE FUSION A B 0.21275000

COLD CHEM $\quad$ B 0.20750000

Levels not connected by same letter are significantly different. 
Oneway Analysis of Measurement (Wt\%) By Prep Method Sample=SRAT Receipt, Element=Mn

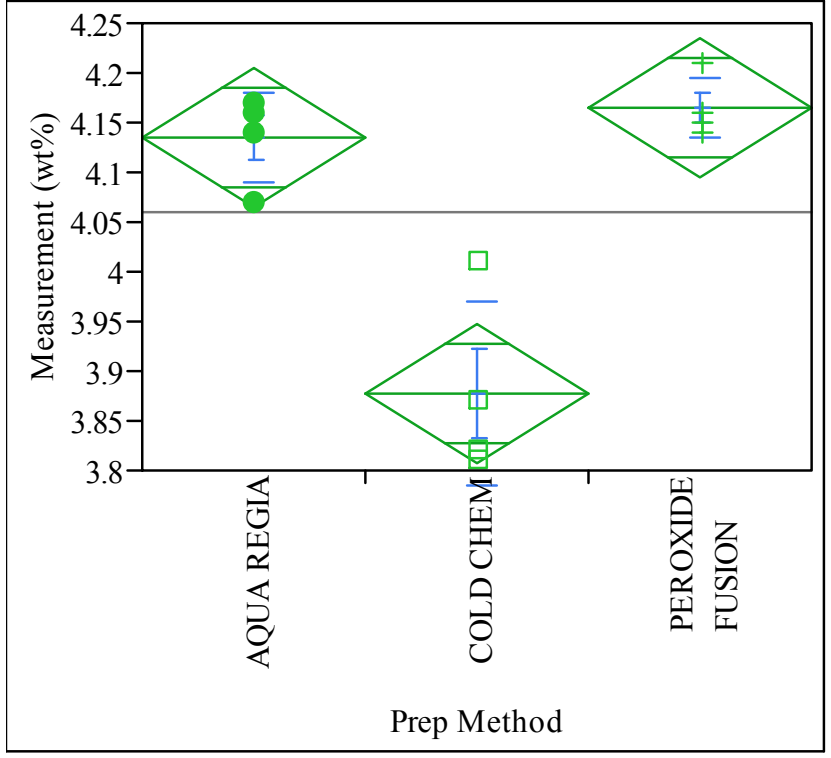

Oneway Anova

Summary of Fit

$\begin{array}{lr}\text { Rsquare } & 0.852854 \\ \text { Adj Rsquare } & 0.820155 \\ \text { Root Mean Square Error } & 0.061891 \\ \text { Mean of Response } & 4.059167 \\ \text { Observations (or Sum Wgts) } & 12\end{array}$

Observations (or Sum 4.059167

Analysis of Variance

Source DF Sum of Squares Mean Square F Ratio Prob $>$ F

$\begin{array}{lllllll}\text { Prep Method } & 2 & 0.19981667 & 0.099908 & 26.0819 & 0.0002\end{array}$

$\begin{array}{llll}\text { Error } & 9 & 0.03447500 & 0.003831\end{array}$

$\begin{array}{lll}\text { C. Total } & 11 & 0.23429167\end{array}$

Means for Oneway Anova

$\begin{array}{lrrrrr}\text { Level } & \text { Number } & \text { Mean } & \text { Std Error } & \text { Lower 95\% } & \text { Upper 95\% } \\ \text { AQUA REGIA } & 4 & 4.13500 & 0.03095 & 4.0650 & 4.2050 \\ \text { COLD CHEM } & 4 & 3.87750 & 0.03095 & 3.8075 & 3.9475 \\ \text { PEROXIDE FUSION } & 4 & 4.16500 & 0.03095 & 4.0950 & 4.2350\end{array}$

Std Error uses a pooled estimate of error variance

Means and Std Deviations

$\begin{array}{lrrrrrr}\text { Means } & \text { Number } & \text { Mean } & \text { Std Dev } & \text { Std Err Mean } & \text { Lower 95\% } & \text { Upper 95\% } \\ \text { Level } & 4 & 4.13500 & 0.045092 & 0.02255 & 4.0632 & 4.2068 \\ \text { AQUA REGIA } & 4 & 3.87750 & 0.092150 & 0.04608 & 3.7309 & 4.0241 \\ \text { COLD CHEM } & 4 & 4.16500 & 0.031091 & 0.01555 & 4.1155 & 4.2145\end{array}$

Tests that the Variances are Equal

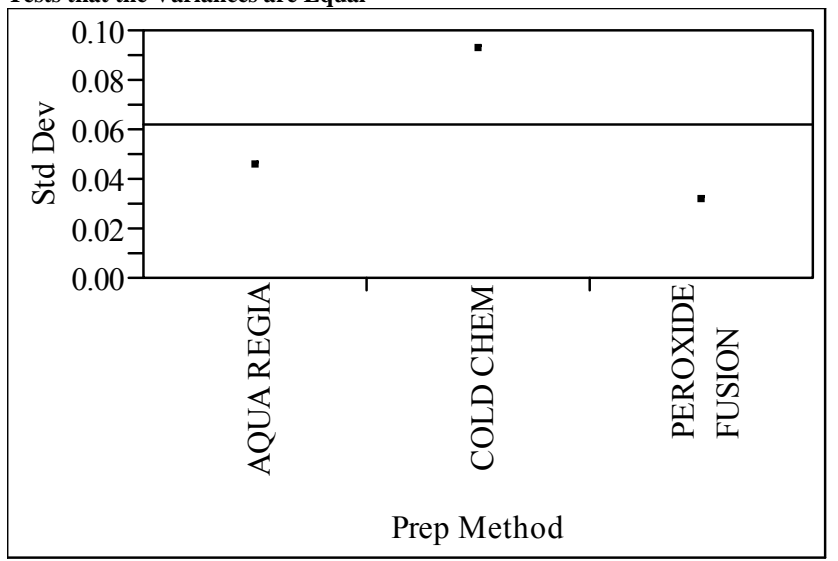

Level

AQUA REGIA

Count Std Dev MeanAbsDif to Mean MeanAbsDif to Median $\begin{array}{rr}0325000 & 0.0300000\end{array}$

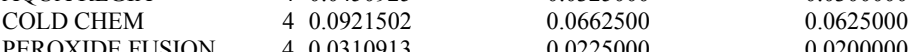

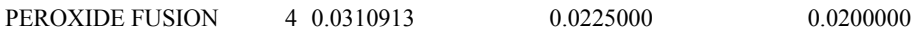

$\begin{array}{lrrrr}\text { Test } & \text { F Ratio } & \text { DFNum } & \text { DFDen } & \text { Prob }>\text { F } \\ \text { O'Brien[.5] } & 1.1276 & 2 & 9 & 0.3656 \\ \text { Brown-Forsythe } & 0.9270 & 2 & 9 & 0.4305 \\ \text { Levene } & 1.7733 & 2 & 9 & 0.2242 \\ \text { Bartlett } & 1.5863 & 2 & . & 0.2047\end{array}$

Warning: Small sample sizes. Use Caution.

Welch Anova testing Means Equal, allowing Std Devs Not Equal

F Ratio DFNum DFDen Prob $>$ F

$\begin{array}{lrrr}15.5471 & 2 & 5.3672 & 0.0058\end{array}$

Means Comparisons

Comparisons for all pairs using Tukey-Kramer HSD

Level

Mean

PEROXIDE FUSION A 4.1650000

AQUA REGIA A 4.1350000

COLD CHEM $\quad$ B 3.8775000

Levels not connected by same letter are significantly different. 
Oneway Analysis of Measurement (Wt\%) By Prep Method Sample=SRAT Receipt, Element=Na

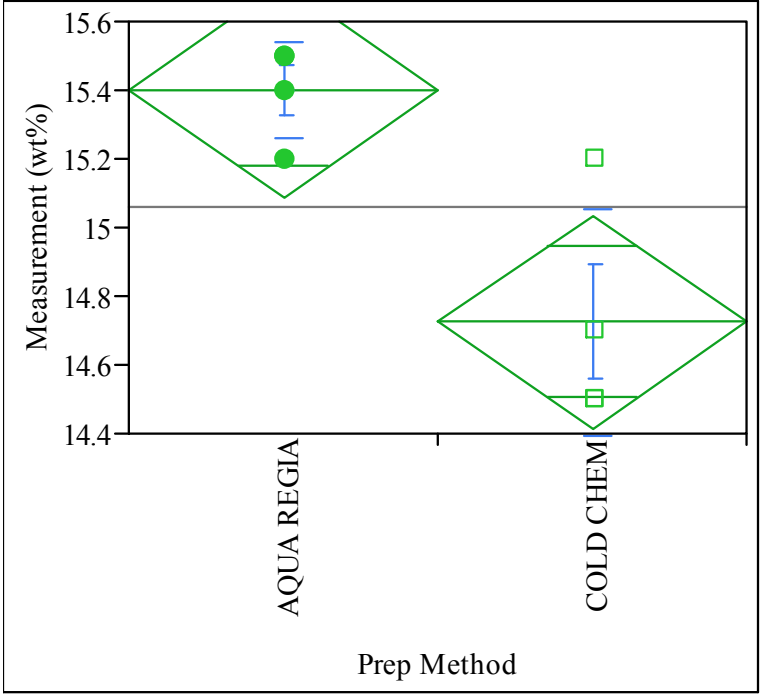

Missing Rows

4

Oneway Anova

Rsquare

Adj Rsquare

Root Mean Square Error

Mean of Response

0.701636

0.651909

Analysis of Variance

Source DF Sum of Squares Mean Square F Ratio Prob > F

$\begin{array}{llllllll}\text { Prep Method } & 1 & 0.9112500 & 0.911250 & 14.1097 & 0.0094\end{array}$

$\begin{array}{lll}\text { Error } & 6 & 0.3875000\end{array}$

1.2987500

\section{Means for Oneway Anova}

$\begin{array}{lrrrrr}\text { Level } & \text { Number } & \text { Mean } & \text { Std Error } & \text { Lower 95\% } & \text { Upper 95\% } \\ \text { AQUA REGIA } & 4 & 15.4000 & 0.12707 & 15.089 & 15.711 \\ \text { COLD CHEM } & 4 & 14.7250 & 0.12707 & 14.414 & 15.036 \\ \text { PEROXIDE FUSION } & 0 & . & . & . & .\end{array}$

Std Error uses a pooled estimate of error variance

\section{Means and Std Deviations}

$\begin{array}{lrrrrrr}\text { Level } & \text { Number } & \text { Mean } & \text { Std Dev } & \text { Std Err Mean } & \text { Lower 95\% } & \text { Upper 95\% } \\ \text { AQUA REGIA } & 4 & 15.4000 & 0.141421 & 0.07071 & 15.175 & 15.625 \\ \text { COLD CHEM } & 4 & 14.7250 & 0.330404 & 0.16520 & 14.199 & 15.251 \\ \text { PEROXIDE FUSION } & 0 & . & . & & . & \end{array}$

Tests that the Variances are Equal

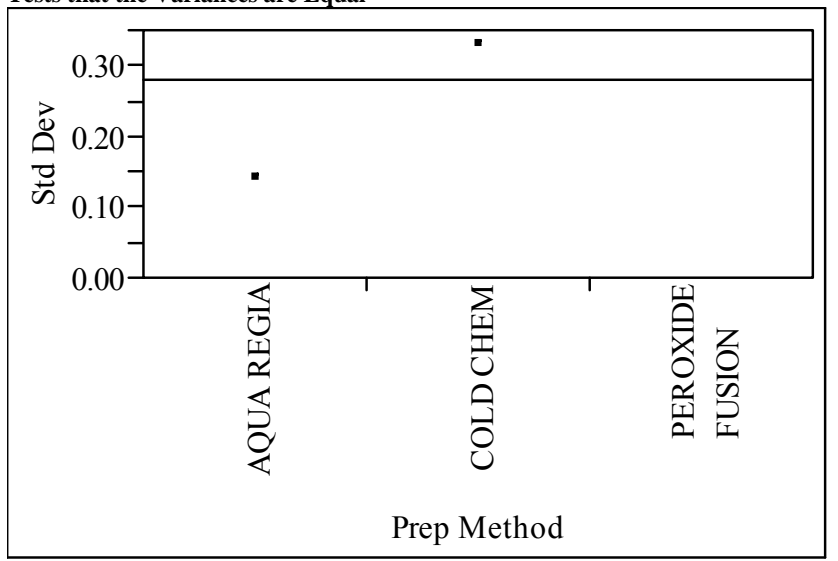

Leve

$\begin{array}{lllll}\text { AQUA REGIA } & 4 & 0.1414214 & 0.1000000 & 0.1000000 \\ \text { COLD CHEM } & 4 & 0.3304038 & 0.2375000 & 0.2250000\end{array}$

Std Dev MeanAbsD

if to Mean MeanAbsDif to Media

PEROXIDE FUSION $0 \quad 0.0000000 \quad 0.250000$

Test F Ratio DFNum DFDen Prob $>F$

$\begin{array}{lllll}\text { O'Brien[.5] } & 1.1404 & 1 & 6 & 0.3266\end{array}$

$\begin{array}{lllll}\text { Brown-Forsythe } & 0.8621 & 1 & 6 & 0.3890\end{array}$

$\begin{array}{lllll}\text { Levene } & 1.8615 & 1 & 6 & 0.2214 \\ \text { Bartlett } & 1.6645 & 1 & . & 0.1970\end{array}$

Warning: Small sample sizes. Use Caution.

Welch Anova testing Means Equal, allowing Std Devs Not Equal

F Ratio DFNum DFDen Prob $>$ F

$\begin{array}{lllll}14.1097 & 1 & 4.0635 & 0.0193\end{array}$ 
Oneway Analysis of Measurement (Wt\%) By Prep Method Sample=SRAT Receipt, Element=N

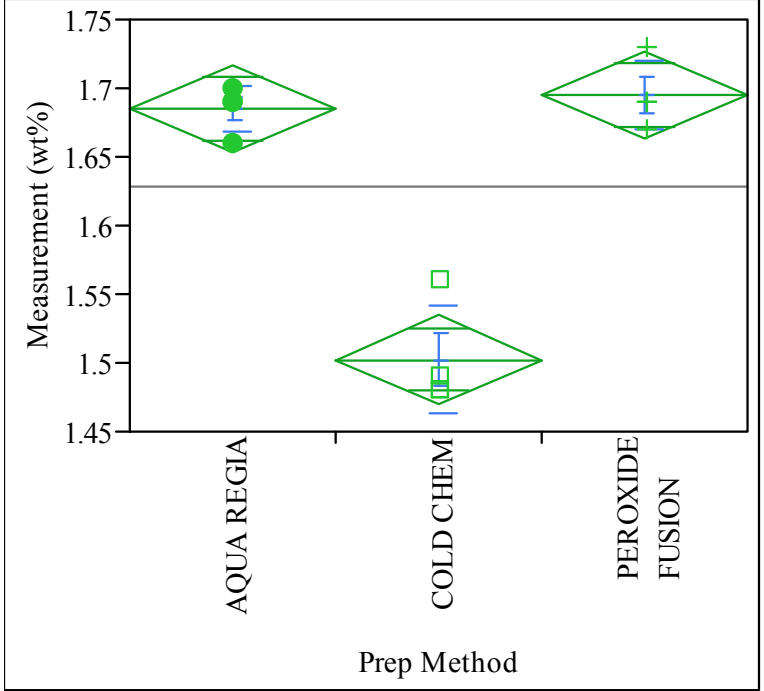

Oneway Anova

Summary of Fi

$\begin{array}{lr}\text { Rsquare } & 0.92813 \\ \text { Adj Rsquare } & 0.912159 \\ \text { Root Mean Square Error } & 0.028431 \\ \text { Mean of Response } & 1.6275 \\ \text { Observations (or Sum Wgts) } & 12\end{array}$

Analysis of Variance

Source DF Sum of Squares Mean Square F Ratio Prob $>$ F

$\begin{array}{llllll}\text { Prep Method } & 2 & 0.09395000 & 0.046975 & 58.1134 & <.0001\end{array}$

$\begin{array}{lrrr}\text { Error } & 9 & 0.00727500 & 0.000808 \\ \text { C. Total } & 11 & 0.10122500\end{array}$

Means for Oneway Anova

$\begin{array}{lrrrrr}\text { Level } & \text { Number } & \text { Mean } & \text { Std Error } & \text { Lower 95\% } & \text { Upper 95\% } \\ \text { AQUA REGIA } & 4 & 1.68500 & 0.01422 & 1.6528 & 1.7172 \\ \text { COLD CHEM } & 4 & 1.50250 & 0.01422 & 1.4703 & 1.5347 \\ \text { PEROXIDE FUSION } & 4 & 1.69500 & 0.01422 & 1.6628 & 1.7272\end{array}$

Std Error uses a pooled estimate of error variance

\section{Means and Std Deviations}

$\begin{array}{lrrrrrrr}\text { Mevel } & \text { Number } & \text { Mean } & \text { Std Dev } & \text { Std Err Mean } & \text { Lower 95\% } & \text { Upper 95\% } \\ \text { Level } & 4 & 1.68500 & 0.017321 & 0.00866 & 1.6574 & 1.7126 \\ \text { AQUA REGIA } & 4 & 1.50250 & 0.038622 & 0.01931 & 1.4410 & 1.5640 \\ \text { COLD CHEM } & 4 & 1.69500 & 0.025166 & 0.01258 & 1.6550 & 1.7350\end{array}$

Tests that the Variances are Equal

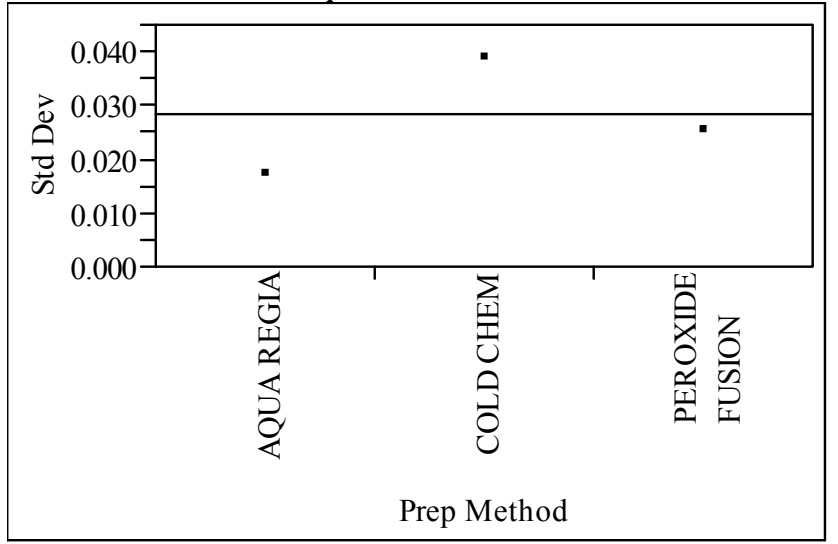

$\begin{array}{lrrrr}\text { Level } & \text { Count } & \text { Std Dev } & \text { MeanAbsDif to Mean } & \text { MeanAbsDif to Median } \\ \text { AQUA REGIA } & 4 & 0.0173205 & 0.0125000 & 0.0100000 \\ \text { COLD CHEM } & 4 & 0.0386221 & 0.0287500 & 0.0225000\end{array}$

Count Std Dev MeanAbsDif to Mean MeanAbsDif to Median

PEROXIDE FUSION $\quad 40.0251661-0.0175000-0.0150000$

Test F Ratio DFNum DFDen Prob $>$ F

$\begin{array}{lllll}\text { O'Brien[.5] } & 0.6369 & 2 & 9 & 0.5512 \\ \text { Brown-Forsythe } & 0.2651 & 2 & 9 & 0.7729\end{array}$

$\begin{array}{lllll}\text { Brown-Forsythe } & 0.2651 & 2 & 9 & 0.7729 \\ \text { Levene } & 1.1770 & 2 & 9 & 0.3515 \\ \text { Bate } & 0.8133 & 2 & & 0.434\end{array}$

Bartlett $\quad 0.8133-2=0.4434$

Warning: Small sample sizes. Use Caution.

Welch Anova testing Means Equal, allowing Std Devs Not Equal

F Ratio DFNum DFDen Prob > F

$\begin{array}{llll}36.4922 & 2 & 5.5137 & 0.0007\end{array}$

Means Comparisons

Comparisons for all pairs using Tukey-Kramer HSD

Level Mean

AQUA REGIA A 1.6850000

COLD CHEM B 1.5025000

Levels not connected by same letter are significantly different. 
Oneway Analysis of Measurement (Wt\%) By Prep Method Sample=SRAT Receipt, Element=S

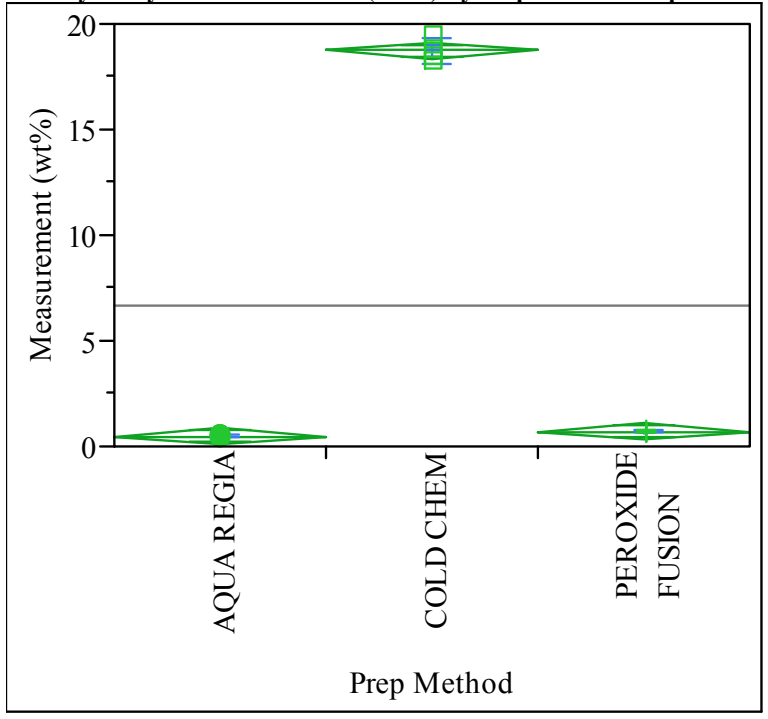

Oneway Anova

Summary of Fit

Rsquare

Adj Rsquare

0.998856

0.998602

Mean of Response Eror 6.642167

Observations (or Sum Wgts) $\quad 12$

Analysis of Variance

Source DF Sum of Squares Mean Square F Ratio Prob $>$ F

$\begin{array}{llllll}\text { Prep Method } & 2 & 876.06597 & 438.033 & 3929.763 & <.000\end{array}$

$\begin{array}{lrl}11 & 1.00319\end{array}$

0.111

\section{Means for Oneway Anova}

$\begin{array}{lrrrrr}\text { Level } & \text { Number } & \text { Mean } & \text { Std Error } & \text { Lower 95\% } & \text { Upper 95\% } \\ \text { AQUA REGIA } & 4 & 0.4908 & 0.16693 & 0.113 & 0.868\end{array}$

$\begin{array}{lrrrrr}\text { AQUA REGIA } & 4 & 0.4908 & 0.16693 & 0.113 & 0.868 \\ \text { COLD CHEM } & 4 & 18.7250 & 0.16693 & 18.347 & 19.103\end{array}$

$\begin{array}{llrrrr}\text { PEROXIDE FUSION } & 4 & 0.7108 & 0.16693 & 0.333 & 1.088\end{array}$

Std Error uses a pooled estimate of error variance

\section{Means and Std Deviations}

$\begin{array}{lrrrrrr}\text { Level } & \text { Number } & \text { Mean } & \text { Std Dev } & \text { Std Err Mean } & \text { Lower 95\% } & \text { Upper 95\% } \\ \text { AQUA REGIA } & 4 & 0.4908 & 0.069591 & 0.03480 & 0.380 & 0.601\end{array}$

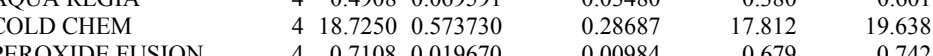

Tests that the Variances are Equal

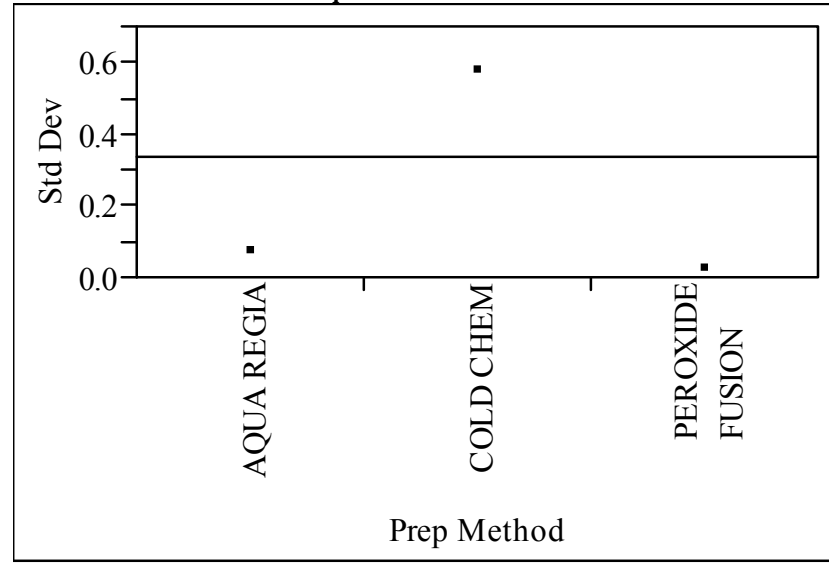

Leve

AQUA REGIA

Count Std Dev MeanAbsDif to Mean MeanAbsDif to Median

COLD CHEM

$$
\begin{array}{ll}
4 & 0.0695911 \\
4 & 0.5737305 \\
4 & 0.019602
\end{array}
$$

$\begin{array}{lll}4 & 0.5737305 \\ 4 & 0.0196702\end{array}$

0.0537500

0.0157500

PEROXIDE FUSION

F Ratio DFNum DFDen Prob $>$ F

$\begin{array}{lllll}\text { O'Brien[.5] } & 2.2568 & 2 & 9 & 0.1606\end{array}$

$\begin{array}{lllll}\text { Brown-Forsythe } & 5.5497 & 2 & 9 & 0.0269 \\ & 6.8641 & 2 & 9 & 0.0155\end{array}$

$\begin{array}{lrrrr}\text { Levene } & 6.8641 & 2 & 9 & 0.0155 \\ \text { Bartlett } & 10.0814 & 2 & & <.0001\end{array}$

Warning: Small sample sizes. Use Caution.

Welch Anova testing Means Equal, allowing Std Devs Not Equal

F Ratio DFNum DFDen Prob $>$ F

$1724.2361 \quad 2 \quad 4.2985<0001$

\section{Means Comparisons}

Comparisons for all pairs using Tukey-Kramer HSD

Level

$\begin{array}{lr}\text { Mean } \\ \text { COLD CHEM } & \text { A } 18.725000\end{array}$

PEROXIDE FUSION B 0.710750

AQUA REGIA $\quad$ B 0.490750

Levels not connected by same letter are significantly different. 
Oneway Analysis of Measurement (Wt\%) By Prep Method Sample=SRAT Receipt, Element=Ti

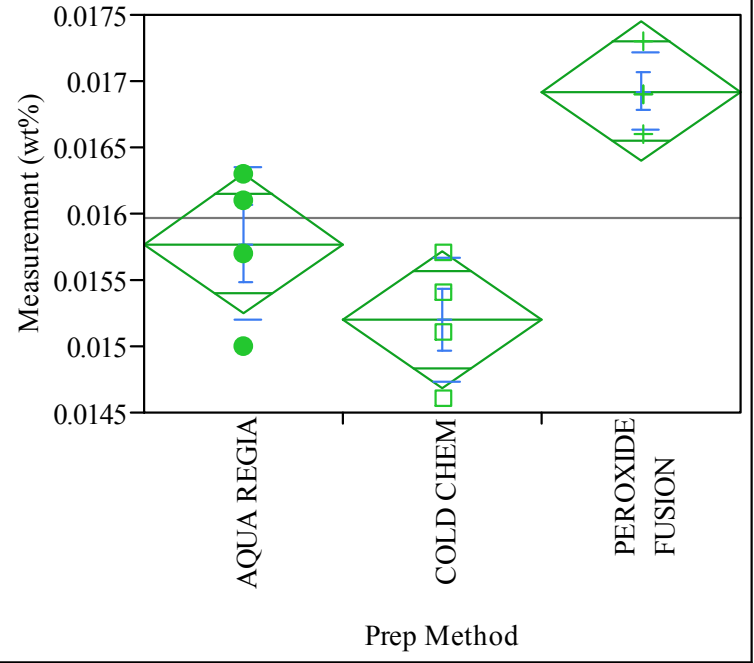

Oneway Anova

$\begin{array}{lr}\text { Rsquare } & 0.765083 \\ \text { Adj Rsquare } & 0.712879 \\ \text { Root Mean Square Error } & 0.000459 \\ \text { Mean of Response } & 0.015967 \\ \text { Observations (or Sum Wgts) } & 12\end{array}$

Analysis of Variance

Source DF Sum of Squares Mean Square F Ratio Prob $>$ F

$\begin{array}{lllll}\text { Prep Method } 2 & 6.17167 \mathrm{e}-6 & 3.0858 \mathrm{e}-6 & 14.6557 & 0.0015\end{array}$

$\begin{array}{lrrr}\text { Error } & 9 & 1.895 \mathrm{e}-6 & 2.1056 \mathrm{e}-7 \\ \text { C. Total } & 11 & 8.06667 \mathrm{e}-6 & \end{array}$

Means for Oneway Anova

$\begin{array}{lrrrrr}\text { Level } & \text { Number } & \text { Mean } & \text { Std Error } & \text { Lower 95\% } & \text { Upper 95\% } \\ \text { AQUA REGIA } & 4 & 0.015775 & 0.00023 & 0.01526 & 0.01629 \\ \text { COLD CHEM } & 4 & 0.015200 & 0.00023 & 0.01468 & 0.01572 \\ \text { PEROXIDE FUSION } & 4 & 0.016925 & 0.00023 & 0.01641 & 0.01744\end{array}$

Std Error uses a pooled estimate of error variance

\section{Means and Std Deviations}

$\begin{array}{lrrrrrr}\text { Level } & \text { Number } & \text { Mean } & \text { Std Dev } & \text { Std Err Mean } & \text { Lower 95\% } & \text { Upper 95\% } \\ \text { AQUA REGIA } & 4 & 0.015775 & 0.000574 & 0.00029 & 0.01486 & 0.01669\end{array}$

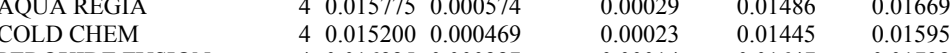

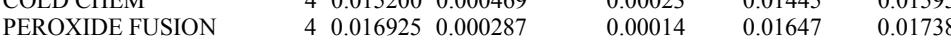

Tests that the Variances are Equal

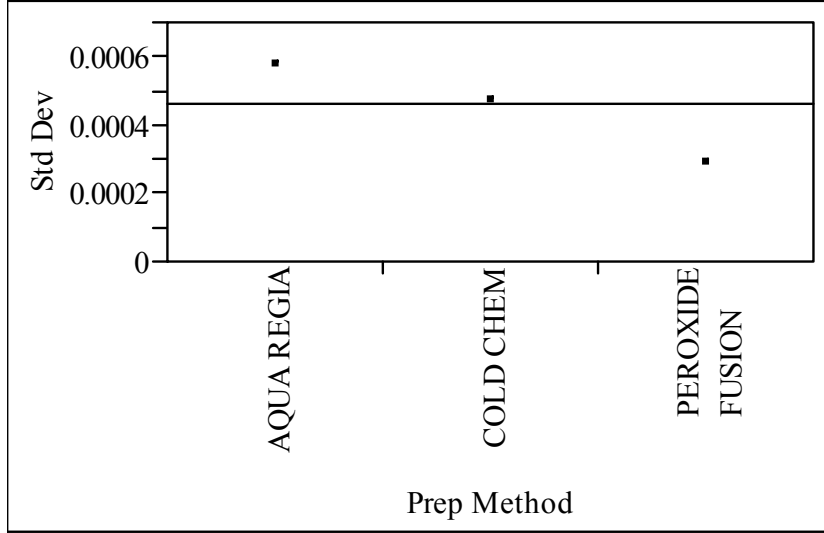

Level

Count Std Dev MeanAbsDif to Mean MeanAbsDif to Median

COLD CHEM

$\begin{array}{rrr}4 & 0.0005737 & 0.000425 \\ 4 & 0.0004690 & 0.000350\end{array}$

0.0003500

0.0004250

MM

$\begin{array}{ll}4 & 0.0004690 \\ 4 & 0.0002872\end{array}$

0.0001875

0.0001750

Test F Ratio DFNum DFDen Prob $>$ F

$\begin{array}{lllll}\text { O'Brien[.5] } & 0.6500 & 2 & 9 & 0.5449 \\ \text { Brown-Fosyt } & 0.9331 & 2 & 9 & 0.4283\end{array}$

$\begin{array}{lllll}\text { Brown-Forsythe } & 0.9331 & 2 & 9 & 0.4283 \\ \text { Levene } & 0.9792 & 2 & 9 & 0.4123\end{array}$

$\begin{array}{lllll}\text { Bartlett } & 0.5830 & 2 & 9 & 0.4123 \\ & & & & 0.5582\end{array}$

Warning: Small sample sizes. Use Caution.

Welch Anova testing Means Equal, allowing Std Devs Not Equal

F Ratio DFNum DFDen Prob $>$ F

19.6621

Means Comparisons

Comparisons for all pairs using Tukey-Kramer HSD

Level

PEROXIDE FUSION A $\quad \begin{array}{r}\text { Mean } \\ 0.01692500\end{array}$

AQUA REGIA $\quad$ B 0.01577500

COLD CHEM $\quad$ B 0.01520000

Levels not connected by same letter are significantly different. 
Oneway Analysis of Measurement (Wt\%) By Prep Method Sample=SRAT Receipt, Element=Zr

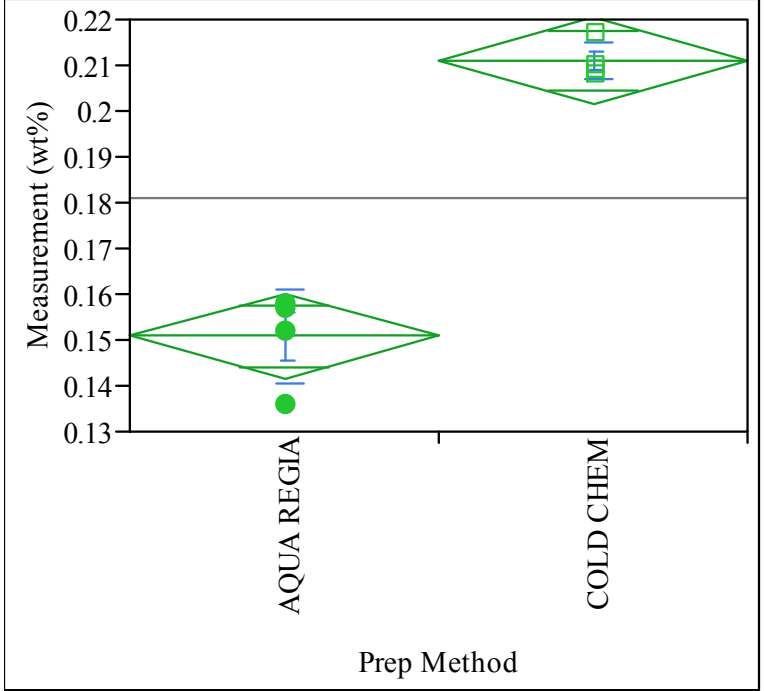

Missing Rows

4

Oneway Anova

$\begin{array}{lr}\text { Rsquare } & 0.952663 \\ \text { Adj Rsquare } & 0.944773 \\ \text { Root Mean Square Error } & 0.007754 \\ \text { Mean of Response } & 0.180875 \\ \text { Observations (or Sum Wgts) } & 8\end{array}$

Analysis of Variance

Source DF Sum of Squares Mean Square F Ratio Prob $>$ F

$\begin{array}{lllllll}\text { Prep Method } & 1 & 0.00726012 & 0.007260 & 120.7505 & <.000\end{array}$

Error $\quad 6 \quad 0.00036075$

$\begin{array}{lll}\text { C. Total } & 7 & 0.00762087\end{array}$

Means for Oneway Anova

$\begin{array}{lrrrrr}\text { Level } & \text { Number } & \text { Mean } & \text { Std Error } & \text { Lower 95\% } & \text { Upper 95\% } \\ \text { AQUA REGIA } & 4 & 0.150750 & 0.00388 & 0.14126 & 0.16024\end{array}$

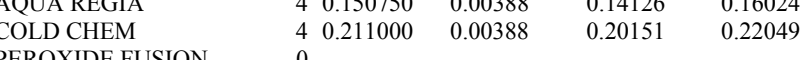

PEROXIDE FUSION

Std Error uses a pooled estimate of error variance

\section{Means and Std Deviations}

$\begin{array}{lrrrrrr}\text { Level } & \text { Number } & \text { Mean } & \text { Std Dev } & \text { Std Err Mean } & \text { Lower 95\% } & \text { Upper 95\% } \\ \text { AQUA REGIA } & 4 & 0.150750 & 0.010178 & 0.00509 & 0.13456 & 0.16694\end{array}$

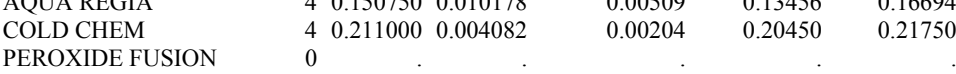

Tests that the Variances are Equal

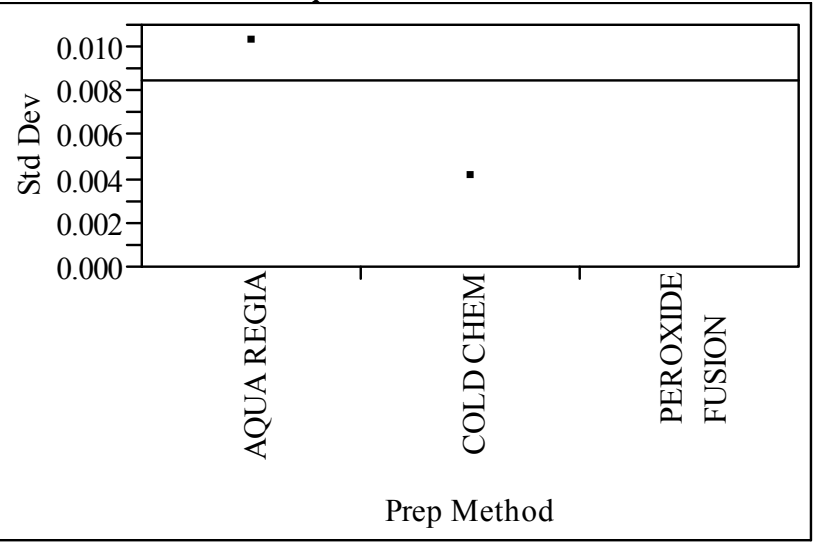

Level Count Std Dev MeanAbsDif to Mean MeanAbsDif to Median

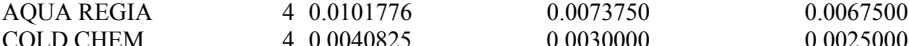
PEROXIDE FUSION $0.040825-0.000000$

Test F Ratio DFNum DFDen Prob $>$ F

$\begin{array}{lrrrr}\text { Test } & \text { F Ratio } & \text { DFNum } & \text { DFDen } & \text { Prob }>\text { F } \\ \text { O'Brien[.5] } & 1.1551 & 1 & 6 & 0.3238\end{array}$

$\begin{array}{lllll}\text { O'Brien[.5] } & 1.1551 & 1 & 6 & 0.3238 \\ \text { Brown-Forsythe } & 0.9909 & 1 & 6 & 0.3580\end{array}$

$\begin{array}{llllll}\text { Brown-Forsythe } & 0.9909 & 1 & 6 & 0.3580 \\ \text { Levene } & 2.1429 & 1 & 6 & 0.1936\end{array}$

Bartlett $\quad 1.9005-12=0.1680$

Warning: Small sample sizes. Use Caution.

Welch Anova testing Means Equal, allowing Std Devs Not Equal

\section{Ratio DFNum DFDen Prob $>$ F}

$\begin{array}{llll}120.7505 & 1 & 3.941 & 0.0004\end{array}$ 
Th and U Axial and Radial Stat Comparison

Data Table: Type

SRAT Product SRAT Product

SRAT Product

SRAT Product

SRAT Product

SRAT Product

SRAT Product

SRAT Product

SRAT Product Pe

Prep

Aqua Regia

Aqua Regia

Aqua Regia

Aqua Regia

Cold Chem

Cold Chem

Cold Chem

Cold Chem

Peroxide Fusion

SRAT Product

SRAT Product

Peroxide Fusion TS144_09_A_105244

SRAT Receipt

SRAT Receipt

SRAT Receipt

SRAT Receipt

SRAT Receipt

SRAT Receipt

SRAT Receipt

SRAT Receipt

SRAT Receipt Peroxide Fusion TS144_09_A_105130 300267075

SRAT Receipt Peroxide Fusion TS144_09_A_105131 300267076

SRAT Receipt Peroxide Fusion TS144_09_A_105132 300267078

\section{LIMS}

300268412

300268413

300268414

300268415

300269104

300269107

300269109

300269110

300268425

00268427

00271682

Aqua Regia TS144 09_A-105512 300271683

Aqua Regia TS144_09_A_105513 300271684

Aqua Regia TS144 09 A 105514300271685

Cold Chem TS144 09 A 105164300267523

Cold Chem TS144_09_A_105165 300267525

Cold Chem TS144 09 A 105166300267526

Cold Chem TS144 09 A 105167300267528

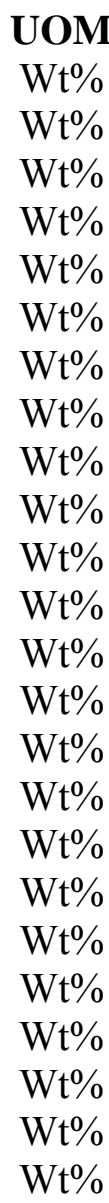

\begin{tabular}{|c|} 
Th Axial \\
2.85 \\
2.89 \\
2.91 \\
2.77 \\
2.46 \\
1.99 \\
2.15 \\
2.14 \\
2.35 \\
2.41 \\
2.18 \\
2.17 \\
3.02 \\
3.07 \\
3.09 \\
3.11 \\
2.77 \\
2.86 \\
. \\
2.21 \\
2.86 \\
2.78 \\
2.79 \\
2.73
\end{tabular}

Th Radial
2.7
2.74
2.72
2.59
$\cdot$
$\cdot$
$\cdot$
.
2.44
2.49
2.29
2.23
2.99
3.05
3.09
3.1
.
.
.
.
2.91
2.85
2.82
2.8

U Axial
2.01
2.03
2.01
1.91
2.03
2
2.01
2.03
1.81
1.83
1.69
1.74
2.43
2.46
2.5
2.51
2.28
2.27
2.36
2.24
2.23
2.16
2.17
2.17

U Radial

1.98

2.04

1.92

1.85

2

1.96

1.99

2

1.87

2.05

1.78

1.99

2.39

2.34

2.46

2.43

2.29

2.19

2.16

2.31

2.24

2.31

2.37 


\section{Variability Chart for Th}

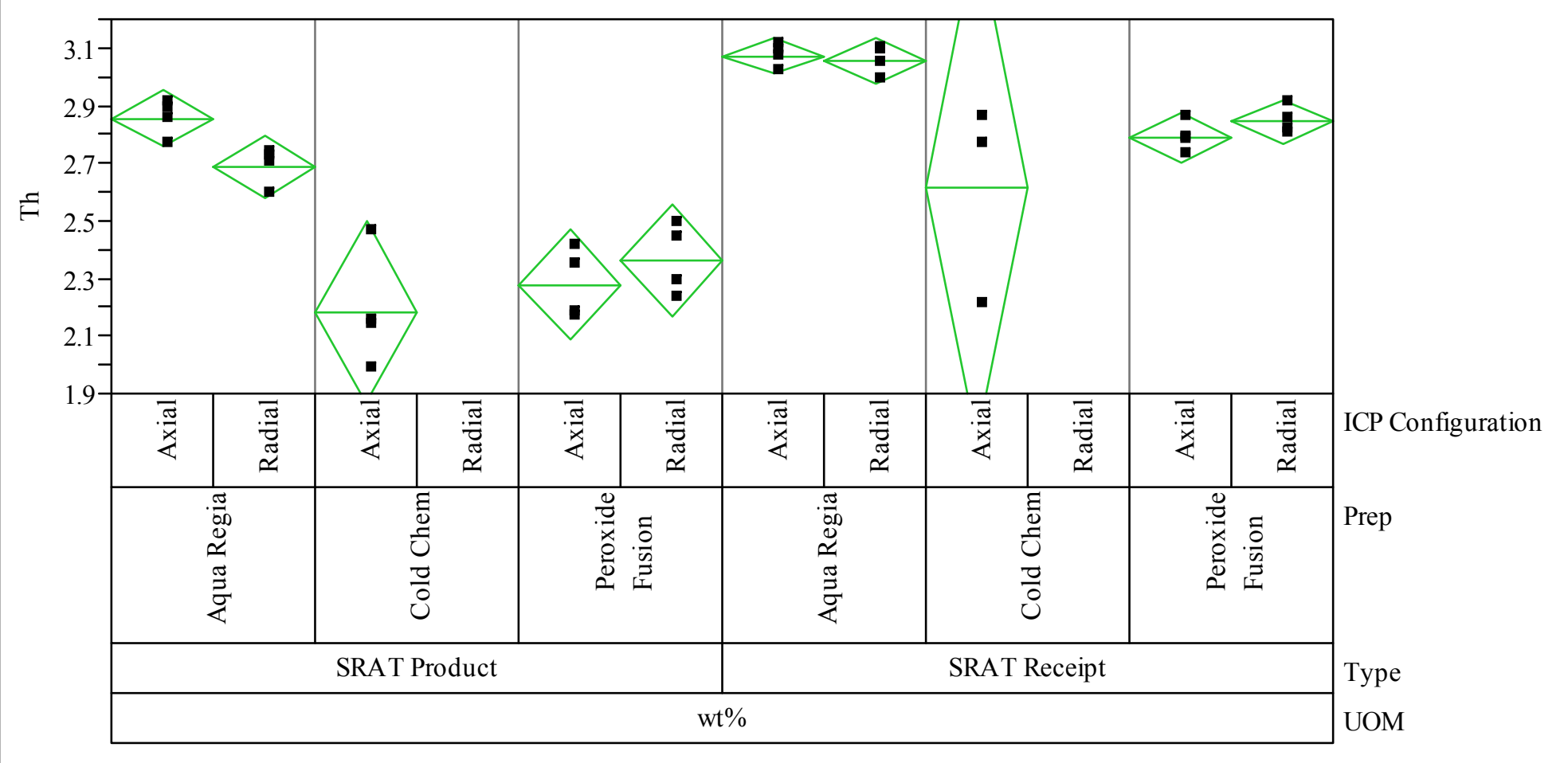




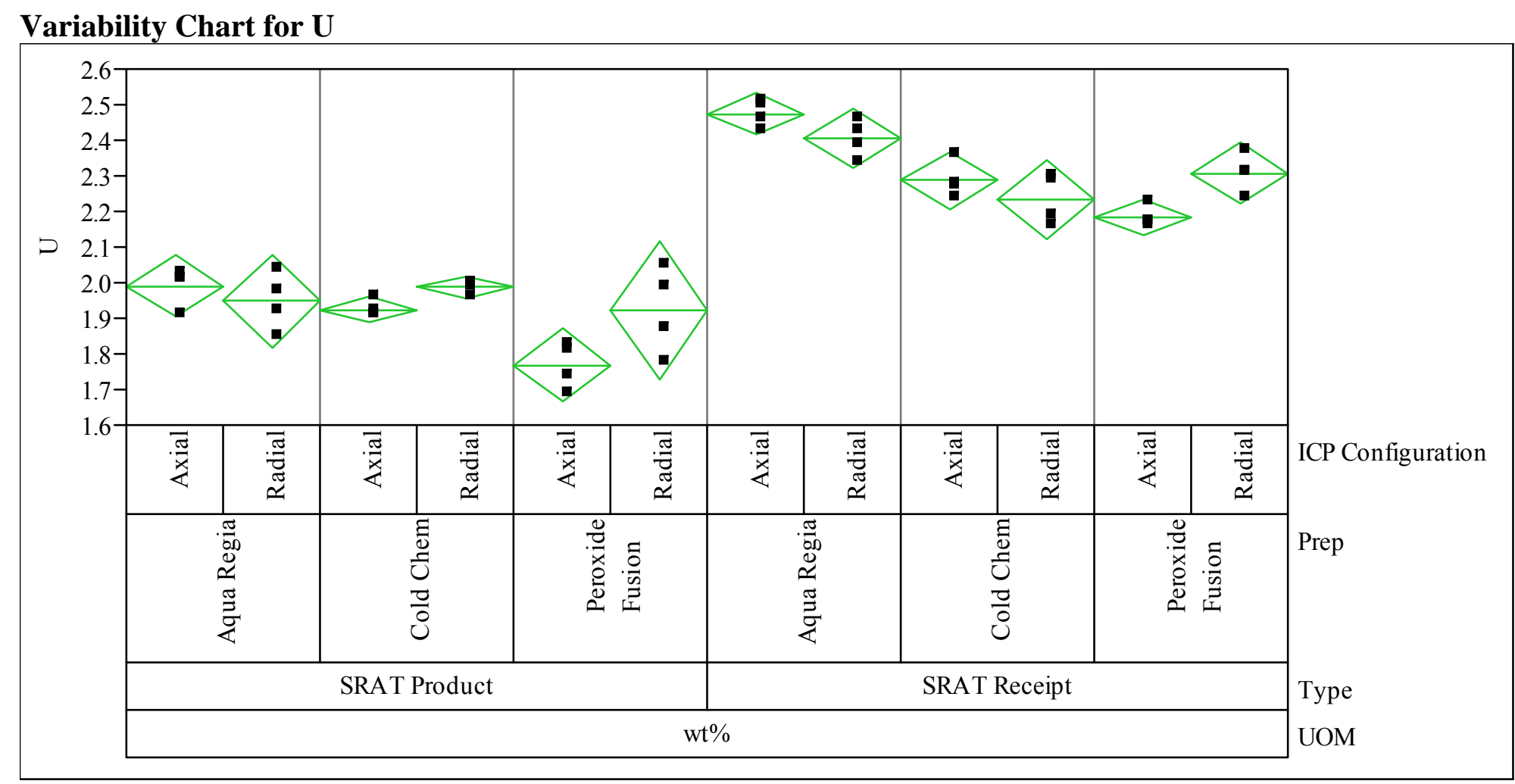


Oneway Analysis of U By Prep/ICP Config Type=SRAT Product

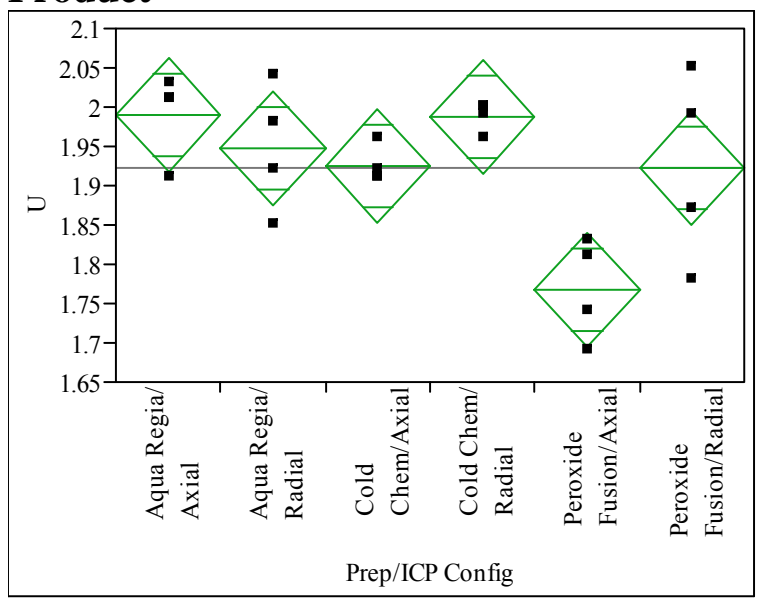

Oneway Anova

Summary of Fit

$\begin{array}{lr}\text { Rsquare } & 0.603671 \\ \text { Adj Rsquare } & 0.49358 \\ \text { Root Mean Square Error } & 0.069841 \\ \text { Mean of Response } & 1.923333 \\ \text { Observations (or Sum Wgts) } & 24\end{array}$

$\begin{array}{lrrrrr}\begin{array}{l}\text { Analysis of Variance } \\ \text { Source }\end{array} & \text { DF } & \begin{array}{r}\text { Sum of } \\ \text { Squares }\end{array} & \begin{array}{r}\text { Mean } \\ \text { Square }\end{array} & \begin{array}{r}\text { F } \\ \text { Ratio }\end{array} & \begin{array}{l}\text { Prob > } \\ \text { F } \\ \text { Prep/ICP }\end{array} \\ \text { Config } & 5 & 0.13373333 & 0.026747 & 5.4834 & 0.0031 \\ \text { Error } & 18 & 0.08780000 & 0.004878 & & \\ \text { C. Total } & 23 & 0.22153333 & & & \end{array}$

Means for Oneway Anova

Level Number Mean Std Lower Upper

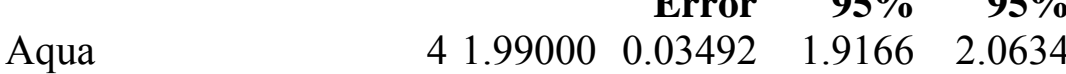

Regia/Axial

Aqua

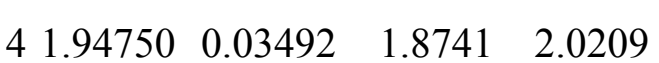

Regia/Radial

Cold

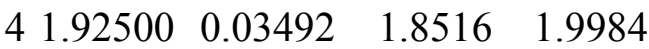

Chem/Axial

Cold

Chem/Radial

Peroxide

$\begin{array}{lllll}4 & 1.98750 & 0.03492 & 1.9141 & 2.0609\end{array}$

Fusion/Axial

Peroxide

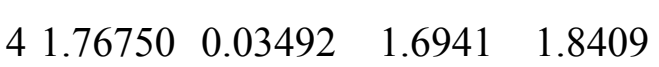

Fusion/Radial

$\begin{array}{lllll}4 & 1.92250 & 0.03492 & 1.8491 & 1.9959\end{array}$

Std Error uses a pooled estimate of error variance

\section{Means Comparisons}

Comparisons for all pairs using Tukey-Kramer HSD

\section{Level}

Aqua Regia/Axial

Cold Chem/Radial

Aqua Regia/Radial

Cold Chem/Axial

$\begin{array}{cr} & \text { Mean } \\ \text { A } & 1.9900000 \\ \text { A } & 1.9875000 \\ \text { A } & 1.9475000 \\ \text { A } & 1.9250000 \\ \text { A B } & 1.9225000 \\ & \text { B } 1.7675000\end{array}$

Peroxide Fusion/Axial

B 1.7675000

Levels not connected by same letter are significantly different. 
Oneway Analysis of U By Prep/ICP Config Type=SRAT

Receipt

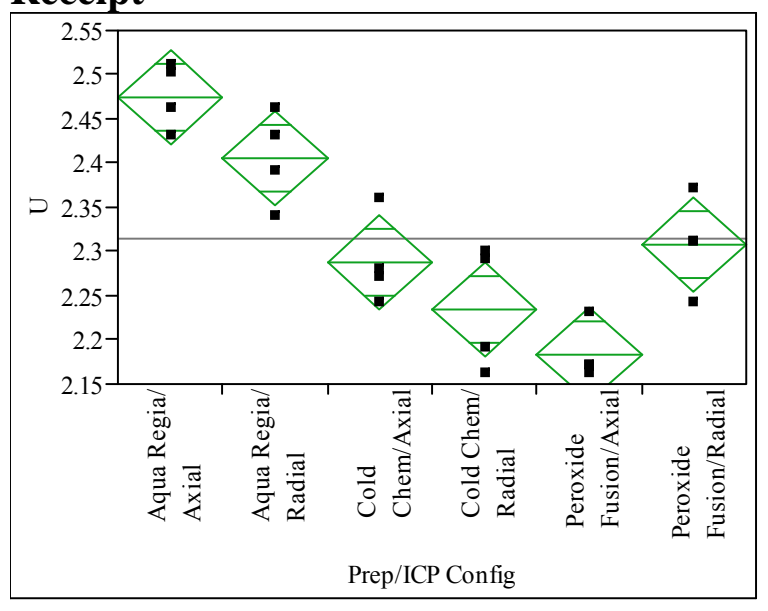

Oneway Anova

Summary of Fit

$\begin{array}{lr}\text { Rsquare } & 0.834074 \\ \text { Adj Rsquare } & 0.787983 \\ \text { Root Mean Square Error } & 0.05084 \\ \text { Mean of Response } & 2.315417 \\ \text { Observations (or Sum Wgts) } & 24\end{array}$

\section{Analysis of Variance}

\begin{tabular}{|c|c|c|c|}
\hline Source & DF & $\begin{array}{l}\text { Sum of } \\
\text { Squares }\end{array}$ & $\begin{array}{l}\text { Mean F Ratio } \\
\text { Square }\end{array}$ \\
\hline Prep/ICP & 5 & 0.23387083 & 0.04677418 .0964 \\
\hline Config & & & \\
\hline Error & 18 & 0.04652500 & 0.002585 \\
\hline C. Total & 23 & 0.28039583 & \\
\hline
\end{tabular}

Means for Oneway Anova

Level Number Mean $\begin{array}{rrr}\text { Std } & \text { Lower } & \text { Upper } \\ \text { Error } & 95 \% & 95 \%\end{array}$

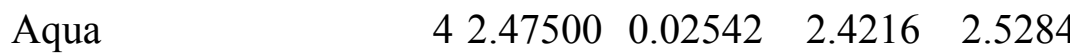

Regia/Axial

Aqua

$\begin{array}{lllll}4 & 2.40500 & 0.02542 & 2.3516 & 2.4584\end{array}$

Regia/Radial

Cold

$\begin{array}{lllll}4 & 2.28750 & 0.02542 & 2.2341 & 2.3409\end{array}$

Chem/Axial

Cold

Chem/Radial

Peroxide

$42.23500 \quad 0.02542 \quad 2.1816 \quad 2.2884$

Fusion/Axial

Peroxide

$42.18250 \quad 0.02542 \quad 2.1291 \quad 2.2359$

Fusion/Radial

Std Error uses a pooled estimate of error variance

\section{Means Comparisons}

Comparisons for all pairs using Tukey-Kramer HSD

$\begin{array}{lrr}\begin{array}{l}\text { Level } \\ \text { Aqua Regia/Axial }\end{array} & & \begin{array}{r}\text { Mean } \\ \text { Aqua Regia/Radial }\end{array} \\ \text { A B } & 2.4750000 \\ \text { Peroxide Fusion/Radial } & \text { B C } & 2.4050000 \\ \text { Cold Chem/Axial } & \text { C D } 2.3075000 \\ \text { Cold Chem/Radial } & \text { C D } 2.2350000 \\ \text { Peroxide Fusion/Axial } & & \text { D } 2.1825000\end{array}$

Levels not connected by same letter are significantly different. 
Oneway Analysis of Th By Prep/ICP Config Type=SRAT Product

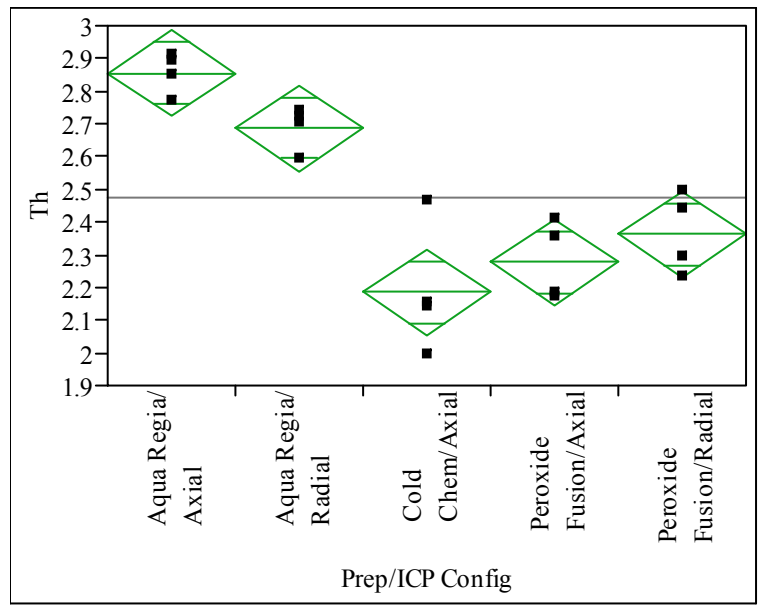

Oneway Anova

Summary of Fit

$\begin{array}{lr}\text { Rsquare } & 0.849336 \\ \text { Adj Rsquare } & 0.809159 \\ \text { Root Mean Square Error } & 0.12405 \\ \text { Mean of Response } & 2.4735 \\ \text { Observations (or Sum Wgts) } & 20\end{array}$

\section{Analysis of Variance}

\begin{tabular}{|c|c|c|c|c|}
\hline Source & DF & $\begin{array}{r}\text { Sum of } \\
\text { Squares }\end{array}$ & $\begin{array}{l}\text { Mean F Ratio } \\
\text { Square }\end{array}$ & Prob > \\
\hline Prep/ICP & 4 & 1.3012300 & 0.32530821 .1399 & $<.0001$ \\
\hline Config & & & & \\
\hline Error & 15 & 0.2308250 & 0.015388 & \\
\hline C. Total & 19 & 1.532055 & & \\
\hline
\end{tabular}

Means for Oneway Anova

Number

$\begin{array}{rrrr}\text { Error } & \mathbf{9 5 \%} & \mathbf{9 5 \%}\end{array}$

$\begin{array}{lllll}\text { Aqua } & 42.85500 & 0.06202 & 2.7228 & 2.9872\end{array}$

Regia/Axial

Aqua

$\begin{array}{lllll}4 & 2.68750 & 0.06202 & 2.5553 & 2.8197\end{array}$

Regia/Radial

Cold

$42.18500 \quad 0.06202 \quad 2.0528 \quad 2.3172$

Chem/Axial

Peroxide

$\begin{array}{lllll}4 & 2.27750 & 0.06202 & 2.1453 & 2.4097\end{array}$

Fusion/Axial

Peroxide

$\begin{array}{lllll}4 & 2.36250 & 0.06202 & 2.2303 & 2.4947\end{array}$

Fusion/Radial

Std Error uses a pooled estimate of error variance

\section{Means Comparisons}

Comparisons for all pairs using Tukey-Kramer HSD

\section{Level}

Mean

Aqua Regia/Axial A 2.8550000

Aqua Regia/Radial A 2.6875000

Peroxide Fusion/Radial B 2.3625000

Peroxide Fusion/Axial $\quad$ B 2.2775000

Cold Chem/Axial B 2.1850000

Levels not connected by same letter are significantly different. 
Oneway Analysis of Th By Prep/ICP Config Type=SRAT

Receipt

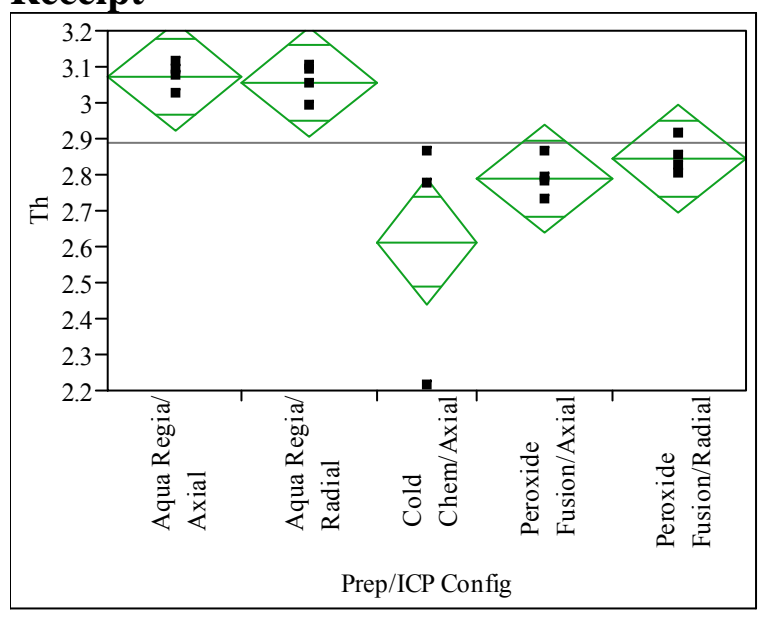

Oneway Anova

Summary of Fit

Rsquare $\quad 0.655041$

Adj Rsquare $\quad 0.556482$

Root Mean Square Error $\quad 0.140285$

Mean of Response 2.889474

Observations (or Sum Wgts) 19

\section{Analysis of Variance}

$\begin{array}{lrrrrr}\text { Source } & \text { DF } & \begin{array}{r}\text { Sum of } \\ \text { Squares }\end{array} & \begin{array}{r}\text { Mean } \\ \text { Square }\end{array} & \begin{array}{r}\text { Fatio } \\ \text { Rrob > }\end{array} & \text { F } \\ \text { Prep/ICP } & 4 & 0.52317807 & 0.130795 & 6.6461 & 0.0032 \\ \text { Config } & & & & & \\ \text { Error } & 14 & 0.27551667 & 0.019680 & & \\ \text { C. Total } & 18 & 0.79869474 & & & \end{array}$

Means for Oneway Anova

Number

$\begin{array}{llll}\text { Error } & \mathbf{9 5 \%} & \mathbf{9 5 \%}\end{array}$

$\begin{array}{lllll}\text { Aqua } & 43.07250 & 0.07014 & 2.9221 & 3.2229\end{array}$

Regia/Axial

Aqua

$\begin{array}{llll}43.05750 & 0.07014 & 2.9071 & 3.2079\end{array}$

Regia/Radial

$\begin{array}{lllll}\text { Cold } & 32.61333 & 0.08099 & 2.4396 & 2.7870\end{array}$

Chem/Axial

Peroxide

$\begin{array}{lllll}4 & 2.79000 & 0.07014 & 2.6396 & 2.9404\end{array}$

Fusion/Axial

Peroxide

$\begin{array}{lllll}4 & 2.84500 & 0.07014 & 2.6946 & 2.9954\end{array}$

Fusion/Radial

Std Error uses a pooled estimate of error variance

\section{Means Comparisons}

Comparisons for all pairs using Tukey-Kramer HSD

\section{Level}

Mean

Aqua Regia/Axial A 3.0725000

Aqua Regia/Radial A 3.0575000

Peroxide Fusion/Radial A B 2.8450000

Peroxide Fusion/Axial A B 2.7900000

Cold Chem/Axial B 2.6133333

Levels not connected by same letter are significantly different. 


\begin{tabular}{|c|c|c|c|c|c|c|c|}
\hline \multicolumn{4}{|c|}{$\begin{array}{l}\text { Matched Pairs Type=SRAT Product, } \\
\text { Prep=Aqua Regia } \\
\text { Difference: Th Radial-Th Axial }\end{array}$} & \multicolumn{4}{|c|}{ Difference: U Radial-U Axial } \\
\hline Th Radial & 2.6875 & $\begin{array}{l}\text { t- } \\
\text { Ratio }\end{array}$ & 16.2499 & U Radial & 1.9475 & $\begin{array}{l}\text { t- } \\
\text { Ratio }\end{array}$ & $\begin{array}{r}- \\
1.9897\end{array}$ \\
\hline Th Axial & 2.855 & DF & 3 & U Axial & 1.99 & DF & 3 \\
\hline $\begin{array}{l}\text { Mean } \\
\text { Difference }\end{array}$ & -0.1675 & $\begin{array}{l}\text { Prob } \\
>|t|\end{array}$ & 0.0005 & $\begin{array}{l}\text { Mean } \\
\text { Difference }\end{array}$ & -0.0425 & $\begin{array}{l}\text { Prob } \\
>|t|\end{array}$ & 0.1407 \\
\hline Std Error & 0.01031 & $\begin{array}{l}\text { Prob } \\
>t\end{array}$ & 0.9997 & Std Error & 0.02136 & $\begin{array}{l}\text { Prob } \\
>t\end{array}$ & 0.9296 \\
\hline Upper95\% & -0.1347 & $\begin{array}{l}\text { Prob } \\
<\mathrm{t}\end{array}$ & 0.0003 & Upper95\% & 0.02548 & $\begin{array}{l}\text { Prob } \\
<\mathrm{t}\end{array}$ & 0.0704 \\
\hline $\begin{array}{l}\text { Lower95\% } \\
\mathrm{N} \\
\text { Correlation }\end{array}$ & $\begin{array}{r}-0.2003 \\
4 \\
0.95193\end{array}$ & & & $\begin{array}{l}\text { Lower95\% } \\
\mathrm{N} \\
\text { Correlation }\end{array}$ & $\begin{array}{r}-0.1105 \\
4 \\
0.87713\end{array}$ & & \\
\hline \multicolumn{4}{|c|}{$\begin{array}{l}\text { Matched Pairs Type=SRAT Product, } \\
\text { Prep=Peroxide Fusion } \\
\text { Difference: Th Radial-Th Axial }\end{array}$} & \multicolumn{4}{|c|}{ Difference: U Radial-U Axial } \\
\hline Th Radial & 2.3625 & $\begin{array}{l}\text { t- } \\
\text { Ratio }\end{array}$ & 8.166536 & U Radial & 1.9225 & $\begin{array}{l}\mathrm{t}- \\
\text { Ratio }\end{array}$ & 3.29837 \\
\hline Th Axial & 2.2775 & $\mathrm{DF}$ & 3 & U Axial & 1.7675 & $\mathrm{DF}$ & 3 \\
\hline $\begin{array}{l}\text { Mean } \\
\text { Difference }\end{array}$ & 0.085 & $\begin{array}{l}\text { Prob } \\
>|t|\end{array}$ & 0.0038 & $\begin{array}{l}\text { Mean } \\
\text { Difference }\end{array}$ & 0.155 & $\begin{array}{l}\text { Prob } \\
>|t|\end{array}$ & 0.0458 \\
\hline Std Error & 0.01041 & $\begin{array}{l}\text { Prob } \\
>t\end{array}$ & 0.0019 & Std Error & 0.04699 & $\begin{array}{l}\text { Prob } \\
>t\end{array}$ & 0.0229 \\
\hline Upper95\% & 0.11812 & $\begin{array}{l}\text { Prob } \\
<\mathrm{t}\end{array}$ & 0.9981 & Upper95\% & 0.30455 & $\begin{array}{l}\text { Prob } \\
<\mathrm{t}\end{array}$ & 0.9771 \\
\hline $\begin{array}{l}\text { Lower95\% } \\
\mathrm{N} \\
\text { Correlation }\end{array}$ & $\begin{array}{r}0.05188 \\
4 \\
0.98547\end{array}$ & & & $\begin{array}{l}\text { Lower95\% } \\
\mathrm{N} \\
\text { Correlation }\end{array}$ & $\begin{array}{r}0.00545 \\
4 \\
0.63795\end{array}$ & & \\
\hline \multicolumn{4}{|c|}{$\begin{array}{l}\text { Matched Pairs Type=SRAT Receipt, } \\
\text { Prep=Aqua Regia } \\
\text { Difference: Th Radial-Th Axial }\end{array}$} & \multicolumn{4}{|c|}{ Difference: U Radial-U Axial } \\
\hline Th Radial & 3.0575 & $\begin{array}{l}\mathrm{t}- \\
\text { Ratio }\end{array}$ & $\begin{array}{r}- \\
2.32379\end{array}$ & U Radial & 2.405 & $\begin{array}{l}\text { t- } \\
\text { Ratio }\end{array}$ & 3.65563 \\
\hline Th Axial & 3.0725 & $\mathrm{DF}$ & 3 & U Axial & 2.475 & DF & 3 \\
\hline $\begin{array}{l}\text { Mean } \\
\text { Difference }\end{array}$ & -0.015 & $\begin{array}{l}\text { Prob } \\
>|t|\end{array}$ & 0.1027 & $\begin{array}{l}\text { Mean } \\
\text { Difference }\end{array}$ & -0.07 & $\begin{array}{l}\text { Prob } \\
>|t|\end{array}$ & 0.0354 \\
\hline Std Error & 0.00645 & $\begin{array}{l}\text { Prob } \\
>t\end{array}$ & 0.9486 & Std Error & 0.01915 & $\begin{array}{l}\text { Prob } \\
>t\end{array}$ & 0.9823 \\
\hline Upper95\% & 0.00554 & $\begin{array}{l}\text { Prob } \\
<\mathrm{t}\end{array}$ & 0.0514 & Upper95\% & -0.0091 & $\begin{array}{l}\text { Prob } \\
<\mathrm{t}\end{array}$ & 0.0177 \\
\hline
\end{tabular}

\begin{tabular}{|c|c|c|c|c|c|c|c|}
\hline Lower95\% & \multicolumn{3}{|l|}{-0.0355} & \multicolumn{4}{|l|}{ Lower95\% } \\
\hline $\mathrm{N}$ & \multicolumn{3}{|l|}{4} & \multicolumn{4}{|c|}{4} \\
\hline Correlation & \multicolumn{3}{|l|}{0.98986} & \multirow{2}{*}{\multicolumn{4}{|c|}{ Difference: U Radial-U Axial }} \\
\hline $\begin{array}{l}\text { Matched Pa } \\
\text { Prep=Perox } \\
\text { Difference: }\end{array}$ & $\begin{array}{l}\text { irs Type } \\
\text { ide Fusio } \\
\text { Th Radia }\end{array}$ & $\begin{array}{l}\text { SRAT } \\
\text {-Th A }\end{array}$ & $\begin{array}{l}\text { Receipt, } \\
\text { kial }\end{array}$ & & & & \\
\hline Th Radial & 2.845 & $\begin{array}{l}\text { t- } \\
\text { Ratio }\end{array}$ & 5.744563 & U Radial & 2.3075 & $\begin{array}{l}\text { t- } \\
\text { Ratio }\end{array}$ & 4.351941 \\
\hline Th Axial & 2.79 & $\mathrm{DF}$ & 3 & U Axial & 2.1825 & DF & 3 \\
\hline $\begin{array}{l}\text { Mean } \\
\text { Difference }\end{array}$ & 0.055 & $\begin{array}{l}\text { Prob } \\
>|t|\end{array}$ & 0.0105 & $\begin{array}{l}\text { Mean } \\
\text { Difference }\end{array}$ & 0.125 & $\begin{array}{l}\text { Prob } \\
>|t|\end{array}$ & 0.0224 \\
\hline Std Error & 0.00957 & $\begin{array}{l}\text { Prob } \\
>t\end{array}$ & 0.0052 & Std Error & 0.02872 & $\begin{array}{l}\text { Prob } \\
>t\end{array}$ & 0.0112 \\
\hline Upper95\% & 0.08547 & $\begin{array}{l}\text { Prob } \\
<\mathrm{t}\end{array}$ & 0.9948 & Upper95\% & 0.21641 & $\begin{array}{l}\text { Prob } \\
<\mathrm{t}\end{array}$ & 0.9888 \\
\hline Lower95\% & 0.02453 & & & Lower95\% & 0.03359 & & \\
\hline $\mathrm{N}$ & 4 & & & $\mathrm{~N}$ & 4 & & \\
\hline Correlation & 0.93467 & & & Correlation & 0.16161 & & \\
\hline
\end{tabular}


$\underline{\text { Distribution }}$

C.J. Bannochie, 773-42A

M.J. Barnes, 773-A

N.E. Bibler, 773-A

J.M. Bricker, 704-27S

L.M. Chandler, 773-A

C.J. Coleman, 773-A

T.B. Edwards, 773-42A

M.T. Feller, 704-28S

T.L. Fellinger, 704-26S

C.M. Gregory, 773-A

C.C. Herman, 999-W

B.W. Holtzscheiter, 704-15S

J.F. Iaukea, 704-30S

P.L. Lee, 773-A

S.L. Marra, 773-A

R.T. McNew, 704-27S

R.N. Mahannah, 704-28S

A.B. Osteen, 704-28S

J.E. Occhipinti, 704-S

D.K. Peeler, 999-W

H.M. Pittman, 704-27S

J.W. Ray, 704-S

D.C. Sherburne, 704-S

M.E. Stone, 999-W

R.H. Young, 773-A

ADS Files 